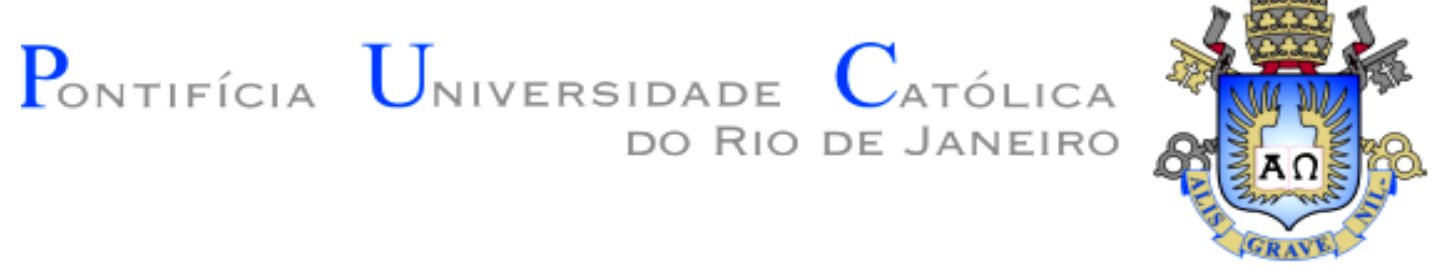

Naiara de Oliveira dos Santos

Depuração Acelerada de Rios Poluídos Usando Peróxido de Hidrogênio

Dissertação de Mestrado

Dissertação apresentada como requisito parcial para obtenção do grau de Mestre pelo Programa de Pós-graduação em Engenharia de Materiais e de Processos Químicos e Metalúrgicos do Departamento de Engenharia de Química e de Materiais da PUC-Rio.

Orientador: Prof. Luiz Alberto Cesar Teixeira

Rio de Janeiro

Março de 2015 


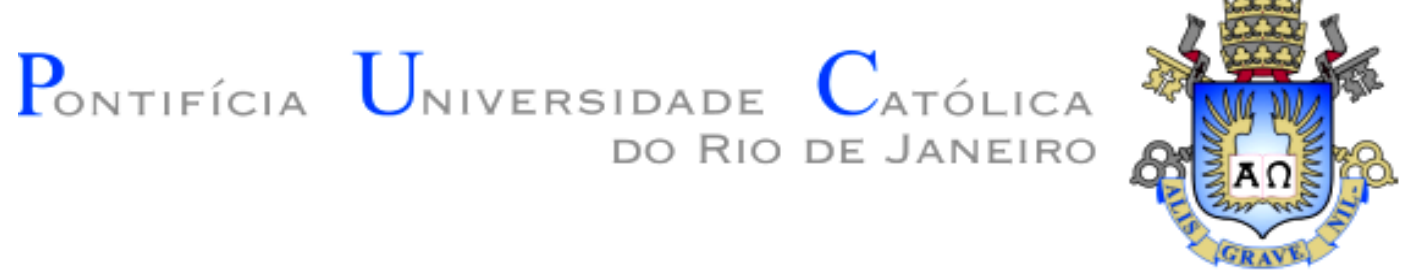

Naiara de Oliveira dos Santos

\section{Depuração Acelerada de Rios Poluídos Usando Peróxido de Hidrogênio}

Dissertação apresentada como requisito parcial para obtenção do grau de Mestre pelo Programa de Pósgraduação em Engenharia de Materiais, Processos Químicos e Metalúrgicos do Departamento de Engenharia Química e de Materiais da PUC-Rio. Aprovada pela Comissão Examinadora abaixo assinada.

Prof. Luiz Alberto Cesar Teixeira

Orientador

Departamento de Engenharia Química e de Materiais -

PUC-Rio

Profa . Lídia Yokoyama

Departamento de Processos Inorgânicos - UFRJ

Prof. José Tavares Araruna Júnior

Departamento de Engenharia Ambiental - PUC-Rio

Prof. José Eugênio Leal

Coordenador Setorial de Pós-Graduação do Centro Técnico Científico da PUC-Rio

Rio de Janeiro, 31 de março de 2015 
Todos os direitos reversados. É proibida a reprodução total ou parcial do trabalho sem autorização da universidade, do autor e do orientador.

\section{Naiara de Oliveira dos Santos}

Graduada em Engenharia Ambiental pela Universidade Severino Sombra (USS) em 2012.

Ficha Catalográfica

Santos, Naiara de Oliveira dos

Depuração acelerada de rios poluídos usando peróxido de hidrogênio / Naiara de Oliveira dos Santos; orientador: Luiz Alberto Cesar Teixeira. - 2015.

163 f. : il. (color.) ; $30 \mathrm{~cm}$

Dissertação (mestrado)-Pontifícia Universidade Católica do Rio de Janeiro, Departamento de Engenharia Química e de Materiais, 2015.

Inclui bibliografia

1. Engenharia Química - Teses. 2. Engenharia de materiais - Teses. 2. Peróxido de hidrogênio. 3. Depuração acelerada. 4. Poluição hídrica. 5. Oxigênio dissolvido. I. Teixeira, Luiz Alberto Cesar. II. Pontifícia Universidade Católica do Rio de Janeiro. Departamento de Engenharia Química e de Materiais. III. Título. 


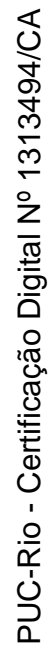

Dedicado aos meus pais, Aloisio e Penha Fátima, pelo apoio e confiança. 


\section{Agradecimentos}

Ao meu orientador, Prof. Luiz Alberto C. Teixeira, pela confiança e sugestão do tema.

A CAPES e à PUC-Rio, pelos auxílios concedidos, sem os quais este trabalho não poderia ter sido realizado.

À Peróxidos do Brasil Ltda. (Grupo Solvay) pelo apoio com equipamentos.

Ao LabTare (UFRJ), na figura da Prof ${ }^{\mathrm{a}}$. Lídia Yokoyama pela disponibilidade do uso dos equipamentos do laboratório. Em especial ao técnico químico Leandro Matosinhos pelos ensinamentos.

Ao Prof. José Marcus Godoy pelo acesso ao laboratório LabAguas da PUC-Rio e ao técnico Alan, pelo auxílio prestado.

Aos colegas do Laboratório de Trat. de Águas e Efluentes Industriais PUC-Rio pela amizade e apoio, em especial à Rafaela Landeiro e ao Bruno Leiva, pelo apoio na formulação do mapa do presente trabalho.

Aos Professores, funcionários e colegas da PUC pelo conhecimento transmitido e auxilio durante os dois anos de mestrado.

Aos meus amigos, que mesmo distante, acompanharam e apoiaram minha trajetória acadêmica, em particular, minha amiga Adir Giannini.

Em especial, ao meu companheiro e namorado, Julio Spadotto, pela cumplicidade, incentivo, carinho e compreensão em todos os momentos desta trajetória.

Um agradecimento à minha família, que sempre torceram, apoiaram e principalmente, acreditaram nessa conquista. Em especial aos meus pais pelo carinho incondicional e confiança. 


\section{Resumo}

Dos Santos, Naiara de Oliveira; Teixeira, Luiz Alberto Cesar (Orientador). Depuração Acelerada de Rios Poluídos Usando Peróxido de Hidrogênio. Rio de Janeiro, 2015. 163 p. Dissertação de Mestrado Departamento de Engenharia de Materiais, Processos Químicos e Metalúrgicos, Pontifícia Universidade Católica do Rio de Janeiro.

Estudos prévios relacionam a ocorrência de episódios de mortandade de peixes em corpos hídricos como a Lagoa Rodrigo de Freitas (LRF) com a rápida disponibilização de espécies poluentes e nutrientes naturais na coluna d'água especialmente durante altas precipitações de chuva, quando ocorre transbordo dos rios poluídos da bacia sobre a água da Lagoa, ocasionando uma demanda de oxigênio dissolvido maior do que o normal para depuração de tais espécies. Nesse contexto existe interesse em evitar episódios críticos de insuficiência de OD na água dos corpos hídricos que possam advir de tais eventos. Estudos realizados no presente trabalho tiveram como objetivo caracterizar as águas de rios da Sub-bacia hidrográfica da LRF através de DBO, COT, SST, $\mathrm{P}_{\text {total }}$ no canal a montante de deságue para a Lagoa em períodos de chuva e de tempo seco; e avaliar um possível tratamento que proporcione a depuração acelerada dos poluentes utilizando peróxido de hidrogênio, fornecendo oxigênio para as águas poluídas através do processo de decomposição do oxidante. Avaliaram-se diferentes dosagens de $\mathrm{H}_{2} \mathrm{O}_{2}$ em tempo reacional de $24 \mathrm{~h}$ de acordo com limites de ecotoxicidade conhecidos. Testes realizados em amostras de rio coletadas em dias de baixa precipitação contendo concentrações de $\mathrm{DBO}$ de até $2,2 \mathrm{mg} / \mathrm{L}$ mostraram uma velocidade de decaimento de $\mathrm{H}_{2} \mathrm{O}_{2}$ inferior ao para amostras tanto coletadas também em dia de baixa precipitação porém com elevada DBO (24,0 mg/L), quanto para dia de alta precipitação $(13,2 \mathrm{~mm}$ em $24 \mathrm{~h}) \mathrm{com}$ relevante concentração de material orgânico. Observou-se uma dosagem suficiente de $15,0 \mathrm{mg} / \mathrm{L}$ para as amostras coletadas em baixa precipitação e alta DBO, e dosagem suficiente de 3,0 mg/L para amostras coletas em maior evento de precipitação (13,2 mm em $24 \mathrm{~h}$ ), acima das quais, não ocorre mais aumento significativo da velocidade de decaimento da $\left[\mathrm{H}_{2} \mathrm{O}_{2}\right]$ e também de velocidade de contribuição de $\mathrm{OD}$ para a água. Concluiu-se que a adição de $\mathrm{H}_{2} \mathrm{O}_{2}$ nas águas de rios durante eventos de poluição causados por chuvas intensas ou lançamento de esgoto pode contribuir para evitar episódios críticos de insuficiência de OD em rios poluídos por material orgânico e na pluma de poluentes que pode ser formada por transbordo dos rios para a LRF.

\section{Palavras-chave}

Peróxido de Hidrogênio; Depuração acelerada; Poluição hídrica; Oxigênio dissolvido. 


\section{Abstract}

Dos Santos, Naiara de Oliveira; Teixeira, Luiz Alberto Cesar (Advisor). Accelerated Depuration of Polluted Rivers Using Hydrogen Peroxide. Rio de Janeiro, 2015. 163 p. MSc. Dissertation - Departamento de Engenharia de Materiais, Processos Químicos e Metalúrgicos, Pontifícia Universidade Católica do Rio de Janeiro.

Previous studies have associated the occurrence of episodes of death of fish in water bodies such as the Lagoa Rodrigo de Freitas (LRF) to to the rapid availability of pollutants and natural nutrients in the water column species especially during high rain precipitation events, which occur when the rivers overflow and pollute the water of the lagoon, causing a biochemical oxygen demand higher than usual for the rate of natural depuration of the contaminating species. In this context there is interest in avoiding critical episodes DO deficiency in the water bodies that may arise from such events. Studies conducted in the present work aimed at characterizing the rivers of sub-basin of LRF through BOD, TOC, TSS, $\mathrm{P}_{\text {total }}$ on the canal that overflows into the lagoon in periods of rain and dry weather; and evaluate a possible treatment offering the accelerated depuration of pollutants using hydrogen peroxide, providing oxygen to the polluted water through the self-decomposition process. The study evaluated the effect of different doses $\mathrm{H}_{2} \mathrm{O}_{2}$ in 24 hours of reaction time according to known ecotoxicity limits. In tests on samples collected from rivers in days of little rain containing BOD concentrations up to $2.2 \mathrm{mg} / \mathrm{L}, \mathrm{H}_{2} \mathrm{O}_{2}$ showed a decay rate lower than those of other samples also collected on days of low precipitation, but with high BOD (24, $0 \mathrm{mg} / \mathrm{L})$, and days of high rainfall (24 hours $13.2 \mathrm{~mm}$ ), with a significant concentration of dissolved organic contaminants. A maximum sufficient dose of $15.0 \mathrm{mg} / \mathrm{L}$ was found for the low and high samples precipitation BOD, and a maximum sufficient dose of $3.0 \mathrm{mg} / \mathrm{L}$ for most of the samples collected during the precipitation event (13.2 $\mathrm{mm} 24$ hours), above which there is no significant increase over the rate of decomposition of $\left[\mathrm{H}_{2} \mathrm{O}_{2}\right]$, and the rate of generation of DO in the water. It was concluded that the addition of $\mathrm{H}_{2} \mathrm{O}_{2}$ into the waters of rivers during pollution events caused by heavy rains or sewage release can help to avoid critical episodes of DO deficiency in polluted rivers by organic matter and pollutant plume that can be formed by overflow of those rivers to the LRF lagoon.

\section{Keywords}

Hydrogen peroxide; Accelerated depuration; Water pollution; Dissolved oxygen 


\section{Sumário}

1. Introdução 24

2. Revisão de Literatura $\quad 27$

2.1 Poluição Hídrica $\quad 27$

2.1.1 Qualidade da água 28

2.1.2 Parâmetros de qualidade da água 29

2.1.3 Indicadores de matéria orgânica na qualidade da água 30

2.1.3.1 Oxigênio Dissolvido 31

$\begin{array}{ll}\text { 2.1.3.2 Carbono } & 37\end{array}$

2.1.3.3 Sólidos Suspensos $\quad 41$

2.1.3.4 Metais 43

2.2 Contaminação Orgânica 43

2.3 Poluição urbana: escoamento superficial 45

2.3.1 As causas da poluição por águas pluviais 45

2.3.2. Influência da precipitação 48

2.4 Sub-bacia hidrográfica da Lagoa Rodrigo de Freitas 49

2.4.1 Lagoa Rodrigo de Freitas 51

2.4.2 Caracterização hidrológica das águas da Bacia 54

2.4.3 Aspectos das sub-bacias $\quad 57$

2.4.3.1 Sub-bacia do Rio Cabeça $\quad 57$

2.4.3.2 Sub-bacia do Rio Rainha 57

2.4.3.3 Sub-bacia do Rio dos Macacos 58

2.4.4 Cenário atual da Lagoa Rodrigo de Freitas 61

2.5 O Peróxido de Hidrogênio em Aplicações Ambientais 65

2.5.1 Processos oxidativos na remoção de poluentes 65

2.5.2 Características do peróxido de hidrogênio 68

2.5.3 Peróxido de hidrogênio em águas superficiais 71

2.5.4 Ecotoxicidade de $\mathrm{H}_{2} \mathrm{O}_{2}$ em águas naturais 73

2.5.5 Experiências da aplicação de peróxido de hidrogênio em
remediação ambiental

3. Materiais e Métodos 78 
3.1 Coleta e época das amostragens 78

3.1.1 Posicionamento dos pontos de amostragem 79

3.2 Análises de caracterização da área de estudo 80

3.2.1 Determinação dos Sólidos Suspensos ou Não Filtráveis $\quad 81$

3.2.1.1 Procedimento Metodológico 81

3.2.2 Demanda Bioquímica de Oxigênio $\left(\mathrm{(BO}_{5}\right)$

3.2.2.1 Procedimento Metodológico 83

3.2.3 Determinação de Carbono Orgânico Total (COT) 84

3.2.3.1 Procedimento Metodológico 84

3.2.4 Determinação de Fósforo Total 85

3.2.4.1 Procedimento Metodológico 85

3.2.5 Determinação de Elementos- traço 86

3.2.5.1 Procedimento Metodológico 86

3.3 Determinação de $\mathrm{H}_{2} \mathrm{O}_{2}$ residual e Oxigênio dissolvido 87

3.3.1 Procedimento Metodológico 87

3.3.1.1 Dosagens de Peróxido de hidrogênio 88

3.3.1.2 Determinação da concentração de Peróxido de hidrogênio residual 88

3.3.1.3 Determinação da concentração de Oxigênio dissolvido 88

3.3.1.4 Determinação do $\mathrm{pH} \quad 89$

3.3.1.5 Tempo de reação dos experimentos 89

4. Resultados e Discussão 90

4.1 Precipitação 90

4.2 Avaliação da qualidade da água do Canal da Rua Gal. Garzón $\quad 90$

4.2.1 Resultados de ressuspensão de sedimentos no ponto de amostragem 3 .

4.2.2 Concentrações de SST, COT e DBO nos pontos de amostragem 1 e 3

4.2.3 Ponto de amostragem 2- contribuição do Rio Cabeça ao Canal da Rua Gal. Garzón 103

4.2.4 Concentração de Fósforo total no Canal da Rua Gal. Garzón 107

4.2.5 Elementos - traço 108

4.3 Experimentos preliminares de aplicação de $\mathrm{H}_{2} \mathrm{O}_{2} \quad 109$ 
4.4 Experimentos de depuração acelerada

4.4.1 Eficiência de remoção da matéria orgânica após dosagens de $\mathrm{H}_{2} \mathrm{O}_{2}$

4.4.2 Possibilidades de aplicação da depuração acelerada em águas de rios poluídos sobre a LRF

5. Conclusões

6. Sugestões para Trabalhos Futuros

7. Referências Bibliográficas

8. Apêndice 


\section{Lista de Figuras}

Figura 1 - Exemplos de inter-relações entre uso e ocupação do solo e focos alteradores da qualidade da água (VON SPERLING, 2005).

Figura 2 - Efeito do lançamento de um efluente sobre o OD de um curso d'água. Fonte. DEZOTTI (2008).

Figura 3 - Etapas da autodepuração. Fonte. (BRAGA et al., 2005). 36

Figura 4 - Evolução da DBO no decorrer do tempo.

Figura 5 - Etapas envolvidas na remoção microbiana de poluentes orgânicos. Fonte. SANT'ANNA (2013).

Figura 6 - Classificação e distribuição dos sólidos em função do tamanho. Fonte. VON SPERLING (2005).

Figura 7 - Principais Bacias e Sub-bacias da cidade do Rio de Janeiro. Em destaque, a localização da Bacia Hidrográfica da Lagoa Rodrigo de Freitas. Fonte. RIO - ÁGUAS (2013).

Figura 8 - Em destaque (em vermelho) áreas de conservação ambiental próximas á Lagoa Rodrigo de Freitas. Fonte.

GEORIO.

Figura 9 - Espelho d'água original (em azul claro) e atual (em azul escuro) da Lagoa Rodrigo de Freitas. Fonte. AMBIENTAL (2012).

Figura 10 - Aspecto do Canal do Jardim de Alah (1) e sua embocadura na praia (2). É possível perceber a areia depositada no fundo do canal em ambas as fotos. Fonte. AMBIENTAL (2012).

Figura 11 - Comporta da Rua Gal. Garzón. Comporta fechada (1); Comporta sendo aberta manualmente por funcionários da Prefeitura (2).

Figura 12 - Principais rios contribuintes à Bacia de estudo. Fonte. AMBIENTAL (2012).

Figura 13 - Foto de satélite da bacia do Rio dos Macacos, com a Lagoa Rodrigo de Freitas como limite de jusante. Destaques para o Rio dos Macacos, em trecho dentro do Jardim Botânico 
(à esquerda), e para o Canal do Jóquei. Fonte: MIGUEZ et al., (2012).

Figura 14 - Perfil longitudinal do Rio dos Macacos identificando a confluência com: (1) Riacho do Pai Ricardo, (2) Rio Algodão, (3) Rio Cabeça e (4) Rio Rainha. Fonte. LUCAS e CUNHA (2007).

Figura 15 - Isolinhas das medianas de Fósforo Total (mg.L-1) do período de 2000 a 2010. Fonte. (DOMINGOS, P. et al., 2012).

Figura 16 - Detalhe do campo de velocidade próximo à llha Piraquê, supondo o Canal do Jardim de Alah com guia - correntes já implantadas. Resultados obtidos pelo programa SisBaHIA. Fonte. DE PAULA (2009).

Figura 17 - Fluxograma de aplicação de peróxido de hidrogênio em corpos hídricos com baixa concentração de oxigênio dissolvido.

Figura 18 - Localização dos pontos de amostragem no Canal da Rua General Garzón. Mapa elaborado no programa Quantum Gis (versão 6.4).

Figura 19- Filtro e bomba de sucção à vácuo. LabAguas (PUCRio). e Figura 20 - Estufa de secagem das amostras. LabAguas (PUC- Rio).

Figura 21 - Fluxograma do procedimento para determinação de sólidos em suspensão de acordo com Manual de Metodologias LabAguas (PUC- Rio) .

Figura 22 - (1) Aparelho digestor - Merck 420. (2) Aparelho espectofotômetro - Spectroquant Nova 80 (Merck).

Figura 23 - Fluxograma do procedimento para determinação de Fósforo Total de acordo com Manual de Metodologias LabAguas (PUC- Rio).

Figura 24 - Equipamento Jartest utilizado durante homogeneização das amostras com o peróxido de hidrogênio.

Figura 25 - Medição de oxigênio dissolvido por oxímetro portátil de luminescência.

Figura 26 - Dados de precipitação dos meses de coleta de agosto a janeiro (2014/2015). Fonte. Adaptado de Instituto Nacional de 
Metereologia (INMET, 2014) - Estação Convencional do Jardim Botânico do Rio de Janeiro.

Figura 27 - (1) Aspecto da água do Canal da Rua Gal. Garzón em evento de contribuição dos três rios da Bacia (Cabeças, Macacos e Rainha) e água do mar. (2) Percebe-se que mesmo com a comporta fechada, ocorria transbordo para a LRF. A seta em amarelo indica a barreira da comporta; a seta em vermelho indica o fluxo da água do canal desaguando para a Lagoa.

Figura 28 - Distribuição dos dados de DBO5 no Canal da Rua Gal. Garzón em três pontos (Ponto1; Ponto 2; Ponto 3). As amostras do Ponto 3 são referentes à antes e após operação de dragagem realizada pela Prefeitura. $O$ volume de precipitação de chuva do dia ficou abaixo de $0,5 \mathrm{~mm}$. Não foi observado durante a coleta lançamento de esgoto ou contribuição do Rio Rainha pelo Canal do Jockey.

Figura 29 - Distribuição dos dados de COT no Canal da Rua Gal. Garzón em três pontos (Ponto1; Ponto 2; Ponto 3). As amostras do Ponto 3 são referentes à antes e após operação de dragagem realizada pela Prefeitura. O volume de precipitação de chuva do dia ficou abaixo de $0,5 \mathrm{~mm}$. Não foi observado durante a coleta lançamento de esgoto ou contribuição do Rio Rainha pelo Canal do Jockey.

Figura 30 - Distribuição dos dados de SST no Canal da Rua General Garzón no Ponto 3 antes e após operação de dragagem realizada pela Prefeitura. O volume de precipitação de chuva do dia ficou abaixo de $0,5 \mathrm{~mm}$. Não foi observado durante a coleta lançamento de esgoto ou contribuição do Rio Rainha pelo Canal do Jockey.

Figura 31 - Distribuição dos dados de $\mathrm{DBO}_{5}(\mathrm{mg} / \mathrm{L})$ versus precipitação de chuva $(\mathrm{mm})$ a partir de amostras coletadas nos meses de agosto a dezembro (2014).

Figura 32 - Aspecto da água no Ponto 3 do Canal da Rua Gal. Garzón em dois momentos: (1) Coleta 3 realizada após taxa de precipitação de chuva abaixo de $0,5 \mathrm{~mm}$, com contribuição do Canal do Jockey e (2) Coleta 5 realizada em tempo seco, com provável lançamento pontual contribuído através do canal do Jockey Clube. 
Figura 33 - Distribuição dos dados de SST versus precipitação de chuva $(\mathrm{mm})$ a partir de amostras coletadas nos meses de agosto a janeiro (2014- 2015).

Figura 34 - Distribuição dos dados de SST versus precipitação dechuva $(\mathrm{mm})$ a partir de amostras coletadas no ponto de amostragem 1 nos meses de novembro a janeiro (2014 - 2015).

Figura 35 - Distribuição dos dados de COT versus precipitação de chuva $(\mathrm{mm})$ a partir de amostras coletadas nos meses de agosto a janeiro (2014- 2015).

Figura 36 - Distribuição dos dados de TOC versus precipitação de chuva $(\mathrm{mm})$ a partir de amostras coletadas no ponto de amostragem 1 nos meses de setembro a janeiro (2014 - 2015).

Figura 37 - Resultados de mediana de [SST] no ponto $3 \mathrm{em}$ relação às coletas de tempo seco e chuvoso.

Figura 38 - Distribuição dos dados de concentração de COT obtidas em coleta de precipitação de chuva abaixo de $0,5 \mathrm{~mm}$ (Coleta 2) e coleta de precipitação de 13,2 mm (Coleta 7) no Canal da Rua Gal. Garzón nos Pontos 1, 2 e 3.

Figura 39 - Distribuição dos dados de oxigênio dissolvido nos pontos 1, 2 e 3 no Canal da Rua Gal. Garzón e no ponto do Canal da Av. Lineu de Paula Machado (ponto anterior à contribuição do Rio Cabeça ao Canal Gal. Garzón). As medições ocorreram após três dias seguidos de precipitação. Os valores de concentração de saturação da figura são baseados na tabela da EPA (2012) de concentração máxima de oxigênio dissolvido de acordo com variação da temperatura.

Figura 40 - Distribuição dos dados de concentração de Fósforo total nos Pontos 1 e 3 do Canal da Rua Gal. Garzón em tempo seco (coleta 5) e em elevada precipitação de chuva (coleta 7).

Figura 41 - Concentração de oxigênio dissolvido em água do rio Rainha sem adição de $\mathrm{H} 2 \mathrm{O} 2$ durante três dias de medição. A [COT] foi de $3,0 \mathrm{mg} \cdot \mathrm{L}^{-1}$ e [CIT] $10,0 \mathrm{mg} \cdot \mathrm{L}^{-1}$. A precipitação acumulada do dia foi $0,0 \mathrm{~mm}$ (RIO - ÁGUAS, 2014). Na figura D0 representa o déficit inicial de oxigênio dissolvido, $\mathrm{C}_{c}$ representa concentração crítica de oxigênio dissolvido e $C_{t}$ representa tempo crítico. As concentrações de saturação do oxigênio dissolvido foram calculadas de acordo com a tabela 
EPA, 2012 (tabela de concentração de oxigênio dissolvido em relação à temperatura).

Figura 42 - Concentração de oxigênio dissolvido do rio Rainha com adições de $[1,0] ;[3,0]$ e $[5,0] \mathrm{mg}^{-\mathrm{L}^{-1}}$ de $\mathrm{H} 2 \mathrm{O} 2$ e amostra sem adição de $\mathrm{H}_{2} \mathrm{O}_{2}$ (river). A precipitação acumulada do dia foi $0,0 \mathrm{~mm}$ (RIO ÁGUAS, 2014). A [COT] foi de 3,0 mg.L-1 e [CIT] 10,0 mg. - $^{-1}$.

Figura 43 - Concentração de oxigênio dissolvido em água do rio Rainha sem adição de $\mathrm{H} 2 \mathrm{O} 2$ durante três dias de medição. A precipitação acumulada do dia foi 3,0 mm (RIO - ÁGUAS, 2014). $\mathrm{Na}$ figura $\mathrm{D}_{0}$ representa o déficit inicial de oxigênio dissolvido, $\mathrm{C}_{\mathrm{c}}$ representa concentração crítica de oxigênio dissolvido e $C_{t}$ representa tempo crítico. As concentrações de saturação do oxigênio dissolvido foram calculadas de acordo com a tabela EPA, 2012 (tabela de concentração de oxigênio dissolvido em relação à temperatura).

Figura 44 - Concentração de oxigênio dissolvido antes e após dosagem de $75,0 \mathrm{mg} . \mathrm{L}^{-1}$ de $\mathrm{H}_{2} \mathrm{O}_{2}$ em água do rio Rainha em dia de chuva moderada. A precipitação acumulada do dia foi $3,0 \mathrm{~mm}$ (RIO ÁGUAS, 2014).

Figura 45 - Concentração de oxigênio dissolvido em água do Canal da Rocinha sem adição de $\mathrm{H}_{2} \mathrm{O}_{2}$ durante um dia e meio de medição. A [COT] foi de $3,0 \mathrm{mg} \cdot \mathrm{L}^{-1}$ e [CIT] $10,0 \mathrm{mg} \cdot \mathrm{L}^{-1}$. A precipitação acumulada do dia ficou abaixo de 0,5 mm (RIO - ÁGUAS, 2014). $\mathrm{Na}$ figura $\mathrm{D}_{0}$ representa o déficit inicial de oxigênio dissolvido, $\mathrm{C}_{c}$ representa concentração crítica de oxigênio dissolvido e $C_{t}$ representa tempo crítico. As concentrações de saturação do oxigênio dissolvido (reta pontilhada na figura) foram calculadas de acordo com a tabela EPA, 2012 (tabela de concentração de oxigênio dissolvido em relação à temperatura).

Figura 46 - Concentração de oxigênio dissolvido do Canal da Rocinha com adições de [1,0]; [5,0]; [10,0]; [15,0] e [20,0] mg..-1 de $\mathrm{H}_{2} \mathrm{O}_{2}$ e amostra sem adição de $\mathrm{H}_{2} \mathrm{O}_{2}$ (river). A precipitação acumulada do dia ficou abaixo de 0,5 mm (RIO - ÁGUAS, 2014).

Figura 47 - Concentrações de [1,0]; [5,0]; [10,0], [15,0] e [20,0] $\mathrm{mg} \cdot \mathrm{L}^{-1}$ de peróxido residual durante 24 horas. A precipitação acumulada do dia ficou abaixo de 0,5 mm (RIO - ÁGUAS, 2014). 
Figura 48 - Concentração de oxigênio dissolvido e peróxido residual aplicado em amostra com água destilada (teste controle). A dosagem aplicada de peróxido foi de $[1,0] \mathrm{mg} . \mathrm{L}^{-1}$.

Figura 49 - Concentração de oxigênio dissolvido em água de rio sem adição de $\mathrm{H}_{2} \mathrm{O}_{2}$ durante dois dias de medição. $\mathrm{A}$ precipitação acumulada do dia foi $0,8 \mathrm{~mm}$ (RIO - ÁGUAS, 2014). $\mathrm{A} \mathrm{DBO}_{5}$ (no Ponto 3) foi de 2,0 $\pm 0,4 \mathrm{mg} \cdot \mathrm{L}^{-1}$.

Figura 50 - Concentração de oxigênio dissolvido do rio em amostra com adição de $12,0 \mathrm{mg} \cdot \mathrm{L}^{-1}$ de $\mathrm{H}_{2} \mathrm{O}_{2}$ e amostra sem adição de $\mathrm{H}_{2} \mathrm{O}_{2}$. A precipitação acumulada do dia foi $0,8 \mathrm{~mm}$ (RIO - ÁGUAS, 2014). A DBO 5 (no Ponto 3) foi de 2,0 $\pm 0,4$ mg. $\mathrm{L}^{-1}$.

Figura 51 - Concentração de oxigênio dissolvido e peróxido residual após adição de 12,0 mg.L-1. A precipitação acumulada do dia foi $0,8 \mathrm{~mm}$ (RIO - ÁGUAS, 2014). A DBO 5 (no Ponto 3) foi de $2,0 \pm 0,4 \mathrm{mg}^{-\mathrm{L}^{-1}}$.

Figura 52 - Pseudo- primeira ordem de reação cinética para a dosagem de $12,0 \mathrm{mg} \cdot \mathrm{L}^{-1}$ de $\mathrm{H}_{2} \mathrm{O}_{2}$ em água de rio contendo 2,0 $\mathrm{mg} \cdot \mathrm{L}^{-1}$ de DBO. A precipitação acumulada do dia foi $0,8 \mathrm{~mm}$ (RIO ÁGUAS, 2014).

Figura 53 - Concentração de oxigênio dissolvido em água de rio sem adição de $\mathrm{H}_{2} \mathrm{O}_{2}$ durante dois dias de medição. A precipitação acumulada do dia ficou abaixo de 0,5 mm (RIO - ÁGUAS, 2014). A $\mathrm{DBO}_{5}$ (no Ponto 3 ) foi de $1,4 \pm 0,5 \mathrm{mg} \cdot \mathrm{L}^{-1}$.

Figura 54 - Concentração de oxigênio dissolvido do rio em amostras com adições de [1,5]; [5,0]; [11,0] e $[20,0] \mathrm{mg}^{-\mathrm{L}^{-1}}$ de $\mathrm{H}_{2} \mathrm{O}_{2}$ e amostra sem adição de $\mathrm{H}_{2} \mathrm{O}_{2}$ (river). A precipitação acumulada do dia ficou abaixo de 0,5 mm (RIO - ÁGUAS, 2014). A DBO 5 (no Ponto 3) foi de $1,4 \pm 0,5 \mathrm{mg} \cdot \mathrm{L}^{-1}$.

Figura 55 - Concentrações de $[1,5] ;[5,0] ;[11,0]$ e $[20,0] \mathrm{mg}^{-1} \mathrm{~L}^{-1}$ de peróxido residual durante 24 horas. A precipitação acumulada do dia ficou abaixo de $0,5 \mathrm{~mm}$ (RIO - ÁGUAS, 2014). A DBO 5 (no ponto 3) foi de $1,4 \pm 0,5 \mathrm{mg} \cdot \mathrm{L}^{-1}$.

Figura 56 - Ordem aparente de reação de decaimento do $\mathrm{H}_{2} \mathrm{O}_{2}$ de acordo com a velocidade inicial das dosagens de [1,5], [5,0], [11,0] e $[20,0] \mathrm{mg} \cdot \mathrm{L}^{-1}$ de $\mathrm{H}_{2} \mathrm{O}_{2}$ em água de rio contendo $1,4 \mathrm{mg} \cdot \mathrm{L}^{-1}$ de DBO. A precipitação acumulada do dia ficou abaixo $0,5 \mathrm{~mm}$ (RIO ÁGUAS, 2014). 
Figura 57 - Constantes cinéticas de pseudo-primeira ordem de decaimento do peróxido para as dosagens de [1,5], [5,0], [11,0] e $[20,0] \mathrm{mg} \cdot \mathrm{L}^{-1}$ de $\mathrm{H}_{2} \mathrm{O}_{2}$ em água de rio contendo $1,4 \mathrm{mg} \cdot \mathrm{L}^{-1}$ de DBO. A precipitação acumulada do dia ficou abaixo de $0,5 \mathrm{~mm}$ (RIO - ÁGUAS, 2014).

Figura 58 - Concentração de oxigênio dissolvido do rio em amostras com adições de $[1,0] ;[5,0] ;[15,0]$ e $[20,0] \mathrm{mg} . \mathrm{L}-1$ de $\mathrm{H}_{2} \mathrm{O}_{2}$. Em 0,37 dias houve nova adição de peróxido para as concentrações de $[1,0]$ e $[5,0] \mathrm{mg} \cdot \mathrm{L}^{-1}$. A precipitação acumulada do dia ficou abaixo de 0,5 $\mathrm{mm}$ (RIO - ÁGUAS, 2014). A DBO 5 (no Ponto 3) foi de $24,0 \pm 0,6$ $\mathrm{mg} \cdot \mathrm{L}^{-1}$. No momento da coleta observava-se a ocorrência de contribuição de esgoto através do Canal do Jockey.

Figura 59 - Concentrações de peróxido residual a partir de 60 minutos $(0,042$ dias $)$ de início da reação com dosagens de [1,0]; $[5,0] ;[15,0]$ e [20] mg. $\mathrm{L}^{-1}$. Em 0,37 dias houve nova adição de peróxido para as concentrações de $[1,0]$ e $[5,0] \mathrm{mg}^{-\mathrm{L}^{-1}}$. A precipitação acumulada do dia ficou abaixo de $0,5 \mathrm{~mm}$ (RIO ÁGUAS, 2014). A $\mathrm{DBO}_{5}$ (no Ponto 3) foi de $24,0 \pm 0,6 \mathrm{mg} \cdot \mathrm{L}^{-1}$. No momento da coleta ocorria contribuição de esgoto através do Canal do Jockey.

Figura 60 - Constantes cinéticas de pseudo-primeira ordem de decaimento do peróxido para as dosagens de $[15,0]$ e $[20,0]$ $\mathrm{mg} \cdot \mathrm{L}^{-1}$ de $\mathrm{H}_{2} \mathrm{O}_{2}$ em água de rio contendo $24,0 \pm 0,6 \mathrm{mg} \cdot \mathrm{L}^{-1} \mathrm{de}$ DBO. A precipitação acumulada do dia ficou abaixo de $0,5 \mathrm{~mm}$ (RIO - ÁGUAS, 2014).

Figura 61 - Concentrações de peróxido residual da aplicação de $\mathrm{H}_{2} \mathrm{O}_{2}=[1,0](1)$ e $[5,0](2) \mathrm{mg} \cdot \mathrm{L}^{-1}$ e de oxigênio dissolvido, antes da reaplicação do oxidante em 0,37 dias de reação.

Figura 62 - Concentrações de peróxido residual da aplicação de $\mathrm{H}_{2} \mathrm{O}_{2}=[1,0]$ (1) e [5,0] (2) mg. $\mathrm{L}^{-1}$ e de oxigênio dissolvido, após reaplicação do oxidante em 0,37 dias de reação.

Figura 63 - Ordem aparente de reação de decaimento do $\mathrm{H}_{2} \mathrm{O}_{2}$ de acordo com a velocidade inicial das dosagens de [1,0], [5,0], [15,0] e $[20,0] \mathrm{mg} \cdot \mathrm{L}^{-1}$ de $\mathrm{H}_{2} \mathrm{O}_{2}$ em água de rio contendo $24,0 \pm 0,6 \mathrm{mg} \cdot \mathrm{L}^{-1}$ de DBO. No momento da coleta ocorria contribuição do Canal do Jockey. A precipitação acumulada do dia ficou abaixo de $0,5 \mathrm{~mm}$ (RIO - ÁGUAS, 2014). 
Figura 64 - Concentração de oxigênio dissolvido do rio em amostras com adições de $[1,5] ;[3,0]$ e $[5,0] \mathrm{mg}^{-\mathrm{L}^{-1}}$ de $\mathrm{H}_{2} \mathrm{O}_{2}$ e amostra sem adição de $\mathrm{H}_{2} \mathrm{O}_{2}$ (river) a partir de 0,042 dias (60 minutos). Em 0,39 dias houve nova adição de peróxido para a concentração de $[1,5] \mathrm{mg} \cdot \mathrm{L}^{-1}$. Em 0,5 dias houve nova adição de peróxido para as concentrações de $[3,0]$ e $[5,0] \mathrm{mg} \mathrm{L}^{-1} \mathrm{~A}$ precipitação acumulada do dia foi 13,2 mm (RIO - ÁGUAS, 2014). A concentração de COT(no Ponto 3) foi de $7,0 \mathrm{mg} \cdot \mathrm{L}^{-1}$.

Figura 65 - Concentrações de peróxido residual a partir de 60 minutos $(0,042$ dias $)$ de início da reação com dosagens de [1,5]; $[3,0]$ e $[5,0] \mathrm{mg} \cdot \mathrm{L}^{-1}$. Em 0,39 dias houve nova adição de peróxido para a concentração de $[1,5] \mathrm{mg} \cdot \mathrm{L}^{-1}$. Em 0,5 dias houve nova adição de peróxido para a concentração de $[1,5] \mathrm{mg} \cdot \mathrm{L}^{-1}$. Em 0,5 dias houve nova adição de peróxido para as concentrações de $[3,0]$ e $[5,0] \mathrm{mg}$. $\mathrm{L}^{-1}$. A precipitação acumulada do dia foi $13,2 \mathrm{~mm}$ (RIO - ÁGUAS, 2014). A [COT] (no Ponto 3) foi de $7,0 \mathrm{mg} \cdot \mathrm{L}^{-1}$.

Figura 66 - Concentrações de peróxido residual da aplicação de $\mathrm{H} 2 \mathrm{O} 2=[1,0](1)$ e $[5,0](2) \mathrm{mg} \cdot \mathrm{L}^{-1}$ e de oxigênio dissolvido, antes da reaplicação do oxidante em 0,5 dias de reação.

Figura 67 - Concentrações de peróxido residual da aplicação de $\mathrm{H} 2 \mathrm{O} 2=[1,0](1)$ e $[5,0](2) \mathrm{mg}^{-\mathrm{L}^{-1}}$ e de oxigênio dissolvido, após reaplicação do oxidante em 0,5 dias de reação.

Figura 68 - Constantes cinéticas de pseudo-primeira ordem de decaimento do peróxido para as dosagens de $[15,0]$ e $[20,0]$ mg. $\mathrm{L}^{-1}$ de $\mathrm{H}_{2} \mathrm{O}_{2}$ em água de rio contendo $7,0 \mathrm{mg} \cdot \mathrm{L}^{-1}$ de COT. A precipitação acumulada do dia ficou abaixo de $0,5 \mathrm{~mm}$ (RIOÁGUAS, 2014).

Figura 69 - Ordem aparente de reação de decaimento do $\mathrm{H}_{2} \mathrm{O}_{2}$ de acordo com a velocidade inicial obtida das dosagens de [1,5], [3,0] e $[5,0] \mathrm{mg} \cdot \mathrm{L}^{-1}$ de $\mathrm{H}_{2} \mathrm{O}_{2}$ em água de rio contendo $7,0 \mathrm{mg} \cdot \mathrm{L}^{-1}$ de COT. No momento da coleta ocorria contribuição de esgoto através Canal do Jockey. A precipitação acumulada do dia foi de 13,2 mm (RIO ÁGUAS, 2014).

Figura 70 - Concentração de COT antes e após dosagem de [1,5], $[3,0]$ e $[5,0] \mathrm{H}_{2} \mathrm{O}_{2}$ mg. $\mathrm{L}^{-1}$. Os resultados referentes às concentrações de $\mathrm{H}_{2} \mathrm{O}_{2}$ após dosagem foram verificados ao término do tempo reacional de $24 \mathrm{hs}$. A precipitaço acumulada do dia foi $13,2 \mathrm{~mm}$ (RIO - ÁGUAS, 2014). 


\section{Lista de Tabelas}

Tabela 1 - Concentração máxima de oxigênio dissolvido de acordo com variação da temperatura. Fonte - EPA (2012).

Tabela 2 - Categorias dos principais componentes em águas de escoamento pluvial. Fonte - Adaptado de LEHNER et al. (1999).

Tabela 3 - Potencial de oxidação de alguns oxidantes em água. Adaptado de MARCELINO et al.(2013); NOGUEIRA (2013).

Tabela 4 - Valores de COT, SST e DBO no ponto 3 do Canal da Rua Gal. Garzón em período seco e chuvoso.

Tabela 5 - Valores limites preconizados na Resolução CONAMA 357/2005 para água doce de Classe II.

Tabela 6 - Concentração de Fósforo total em tempo seco e em 13,2 mm de precipitação de chuva no Canal da Rua Gal.

Garzón.

Tabela 7 - Concentração de Fe em tempo seco e em 13,2 mm de precipitação de chuva no Canal da Rua Gal. Garzón.

Tabela 8 - Velocidade inicial de decaimento das concentrações de peróxido em 85 minutos ( 0,06 dias) de reação.

Tabela 9 - Velocidade inicial de decaimento das concentrações de peróxido em 60 minutos $(0,042$ dias) de reação.

Tabela 10 - Constantes cinéticas de pseudo- primeira ordem de decaimento do $\mathrm{H}_{2} \mathrm{O}_{2}$ de acordo com a velocidade inicial da reação.

Os valores são referentes aos experimentos 1, 2, 3 e 4 de dosagem de $\mathrm{H}_{2} \mathrm{O}_{2}$ em água de rio obtida do ponto de amostragem 3 do Canal Gal. Garzón em diferentes eventos de precipitação. 


\section{Lista de abreviações}

$\mathrm{C}_{c}$ - Concentração crítica de oxigênio dissolvido

COD - Carbono Orgânico Dissolvido

COT - Carbono Orgânico Total

$\mathrm{C}_{s}$ - Concentração de saturação de oxigênio dissolvido

$D_{0}$ - Déficit Inicial de Oxigênio

DBO - Demanda Bioquímica de Oxigênio

DQO - Demanda Química de Oxigênio

LRF - Lagoa Rodrigo de Freitas

MO - Matéria Orgânica

OD - Oxigênio Dissolvido

SST - Sólidos Suspensos Totais

$t_{c}$ - Tempo crítico (tempo necessário para ocorrer a menor concentração de oxigênio dissolvido na água) 


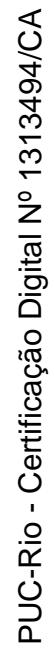

Na vida não existe nada a se temer, apenas a ser compreendido.

Marie Curie (1867-1934). 


\section{Introdução}

Os recursos hídricos devido às suas diversas finalidades, como o abastecimento doméstico e industrial, irrigação agrícola, recreação, atividade pesqueira, geração de energia entre outras, vêm sendo nas últimas décadas cada vez mais requeridos. Mas tão ou mais importante que a questão envolvendo a quantidade de água disponível, apresenta-se também a questão de sua qualidade. Os corpos hídricos ao redor de nosso planeta têm se deteriorado de forma crescente, especialmente nos últimos 50 anos (GRASSI, 2001). Os impactos decorrentes deste acelerado processo de urbanização acompanhado à falta de planejamento vão desde a impermeabilização dos solos (através do aumento da velocidade e do volume de escoamento superficial das águas de chuva) ao aumento da poluição difusa e pontual, o que altera significativamente na qualidade da água, criando impactos adversos aos organismos aquáticos e consequentemente afetando o equilíbrio ecológico como um todo.

Os esgotos doméstico e industrial também introduzem nos sistemas aquáticos diversos tipos de poluentes, principalmente matéria orgânica; a qual exerce uma importante função no processo de ciclagem de nutrientes. Porém, em rios urbanizados e poluídos, a qualidade da água pode sofrer ainda mais impactos negativos em função dessas fontes antrópicas lançadas em excesso. Quando bactérias e outros organismos detritívoros decompõem a matéria orgânica, ocorre o consumo do oxigênio que se encontra dissolvido na água, o que poderá resultar em um déficit significativo disponível para a população aquática aeróbia, ocasionando mortandade de peixes e até alteração na cadeia trófica local.

Entre os sistemas aquáticos mais afetados pelas atividades antrópicas decorrentes do processo de urbanização, encontram-se as lagoas costeiras; principalmente por muitas vezes situarem-se em áreas densamente habitadas na faixa litorânea, sendo geralmente receptoras naturais de sub-bacias fluviais, o que as coloca indiscutivelmente segundo DOMINGOS et al.(2012) entre os sistemas mais impactados pelas atividades antrópicas, destacando-se o lançamento de efluentes domésticos e industriais in natura. 
A Lagoa Rodrigo de Freitas assim como algumas lagoas costeiras do Estado do Rio de Janeiro, tem despertado interesse de investigação, principalmente devido aos constantes fenômenos de poluição, inclusive à mortandade de peixes (tendo sido a última registrada Março de 2013), fator este decorrente do processo de anoxia em determinados eventos no corpo hídrico.

O interesse de estudar tanto a Lagoa Rodrigo de Freitas quanto as subbacias que em determinadas épocas deságuam nesta, é devido à importância ambiental da sub-bacia hidrográfica que concentra tais corpos hídricos. A dinâmica da Lagoa Rodrigo de Freitas vêm sendo estudada há alguns anos, sendo citado pela literatura que entre as causas da mortandade de peixes, está atribuído o excesso de matéria orgânica lançado irregularmente por esgotos e o deságue de rios com alta carga orgânica à Lagoa durante eventos de forte chuva, o que causa a redução do oxigênio dissolvido na água, levando à hipoxia e anoxia do meio.

O presente trabalho buscou seguir a atual pesquisa e desenvolvimento de processos e tecnologias ambientais, voltados a tratamentos limpos, que removam ou contribuam para a redução dos poluentes presentes nos corpos hídricos com eficiência e sem alterar negativamente as características do meio. Para tal, estudou-se um tratamento que proporcionasse uma significativa contribuição de oxigênio dissolvido à água poluída durante esses eventos de deságue dos rios à Lagoa, buscando aumentar a degradação dos poluentes através do fornecimento de oxigênio para os microorganismos aeróbios decompositores, a fim de manter a estabilidade dos níveis de oxigenação das águas da Lagoa, reduzindo assim, o risco de ocorrência de eventos de mortandade da fauna aquática.

Foi então avaliado a viabilidade da utilização do peróxido de hidrogênio $\left(\mathrm{H}_{2} \mathrm{O}_{2}\right)$, um oxidante que vem sendo cada vez mais utilizado no tratamento de ambientes contaminados, principalmente em efluentes industriais (geralmente combinados a outros reagentes e /ou processos para aumentar sua eficiência). Seus produtos de decomposição (água e oxigênio) o tornam favorável ao potencial uso em águas naturais. No Brasil, esta prática ainda não é recorrente, não havendo muitos estudos na aplicabilidade do peróxido para tratar eventos de poluição de corpos hídrico naturais; sendo aplicado geralmente em plantas industriais, em estações de tratamento de água potável e estações de tratamento de esgoto, além 
de no controle de cianobactérias em reservatórios de água para abastecimento. Porém, em países como o Reino Unido, o peróxido vem sendo utilizado desde a década de 90 para suplementar o oxigênio de água de rios, a fim de evitar situações críticas de seu déficit.

Portanto, essa pesquisa busca estudar uma nova tecnologia ainda pouco difundida no Brasil, com o objetivo de auxiliar na prevenção dos impactos futuros decorrentes de determinados eventos ou condições específicas de poluição na Lagoa Rodrigo de Freitas e em seus rios afluentes, como também de outros corpos hídricos que apresentem risco de desenvolver episódios críticos de baixa oxigenação e consequente mortandade de peixes. 


\section{Revisão de Literatura}

\subsection{Poluição Hídrica}

O crescimento populacional nas ultimas décadas tem transformado o Brasil em um país essencialmente urbano ( $83 \%$ da população é urbana), onde em algumas cidades, aproximadamente metade vive em áreas irregulares. Como consequência deste processo de urbanização, cresce o número de áreas impermeáveis e canalização dos rios urbanos (com aumento de fase de inundação), além do aumento da quantidade de resíduos sólidos que afetam a qualidade da água dos rios próximos a essas áreas urbanas (TUCCI, 2008).

VARGAS (1999) destaca os impactos negativos da urbanização sobre o ciclo hidrológico que culminam na perda das potencialidades de uso da água. Tais impactos resultam tanto da impermeabilização do solo (aumento da velocidade e do volume de escoamento superficial das águas; aumento do número e da frequência das inundações; incremento da poluição difusa pela lavagem das superfícies urbanizadas), quanto do próprio consumo de água na escala urbana (lançamento de esgotos com ou sem tratamento nos cursos d'água; aumento da DBO nos corpos hídricos e diminuição da capacidade de autodepuração). Ainda segundo o autor, nas bacias mais urbanizadas, especialmente nos países em desenvolvimento, o uso urbano costuma ser o principal responsável pela poluição orgânica dos rios.

Existem duas estratégias adotadas no controle da poluição aquática:

$\checkmark$ Redução na fonte;

$\checkmark$ Tratamento dos rejeitos de forma a remover os contaminantes ou ainda de convertê-los a uma forma menos nociva.

A redução na fonte pode ser aplicada a contaminantes provenientes de ambas as fontes, tanto pontuais quanto difusas (GRASSI, 2001). De acordo com o autor, as fontes pontuais compreendem a descarga de efluentes a partir de indústrias e estações de tratamento de esgoto, dentre outras. Estas fontes são de identificação 
simples, e, portanto podem ser facilmente monitoradas e regulamentadas. É relativamente fácil se determinar a composição destes resíduos, assim como definir seu impacto ambiental. Além disso, é possível responsabilizar o agente poluidor, caso haja necessidade. As fontes difusas ao contrário, apresentam características bastante diferenciadas. Elas se espalham por inúmeros locais e são particularmente difíceis de serem determinadas, em função das características intermitentes de suas descargas e também da abrangência sobre extensas áreas.

\subsubsection{Qualidade da água}

Em relação aos constituintes naturais da água, de acordo com PARRON et al. (2011), há uma grande variedade de elementos e substâncias químicas dissolvidas, e a sua fonte predominante é o intemperismo das rochas, resultante do fluxo de água que dissolve os minerais e transporta os íons dissolvidos para os rios e oceanos, onde, eventualmente em parte, são incorporados aos sedimentos. Já as contribuições humanas aos corpos d'água incluem íons e substâncias solúveis de atividades industriais, de mineração, despejos de esgotos e outros resíduos.

De maneira geral, pode-se dizer que a qualidade de uma determinada água é função das condições naturais e do uso e da ocupação do solo na bacia hidrográfica. Tal se deve aos seguintes fatores (VON SPERLING, 2005):

- Condições naturais: mesmo com a bacia hidrográfica preservada nas suas condições naturais, a qualidade das águas é afetada pelo escoamento superficial e pela infiltração nos solos, resultante da precipitação atmosférica. Assim, a incorporação de sólidos em suspensão (ex.: partículas de solo) ou dissolvidos (ex.: íons oriundos da dissolução de rochas) ocorre, mesmo na condição em que a bacia hidrográfica esteja totalmente preservada em suas condições naturais (ex.: ocupação do solo com matas e florestas). Neste caso, tem grande influência a cobertura e a composição do solo.

- Interferência dos seres humanos: seja de uma forma concentrada, como na geração de despejos domésticos ou industriais, quer de uma forma dispersa, como na aplicação de defensivos agrícolas no solo, contribui na introdução de 
compostos na água, afetando a sua qualidade. Logo, a forma com que o homem usa e ocupa o solo tem uma implicação direta na qualidade da água. A Figura 1 apresenta as formas antrópicas alteradoras da qualidade da água.

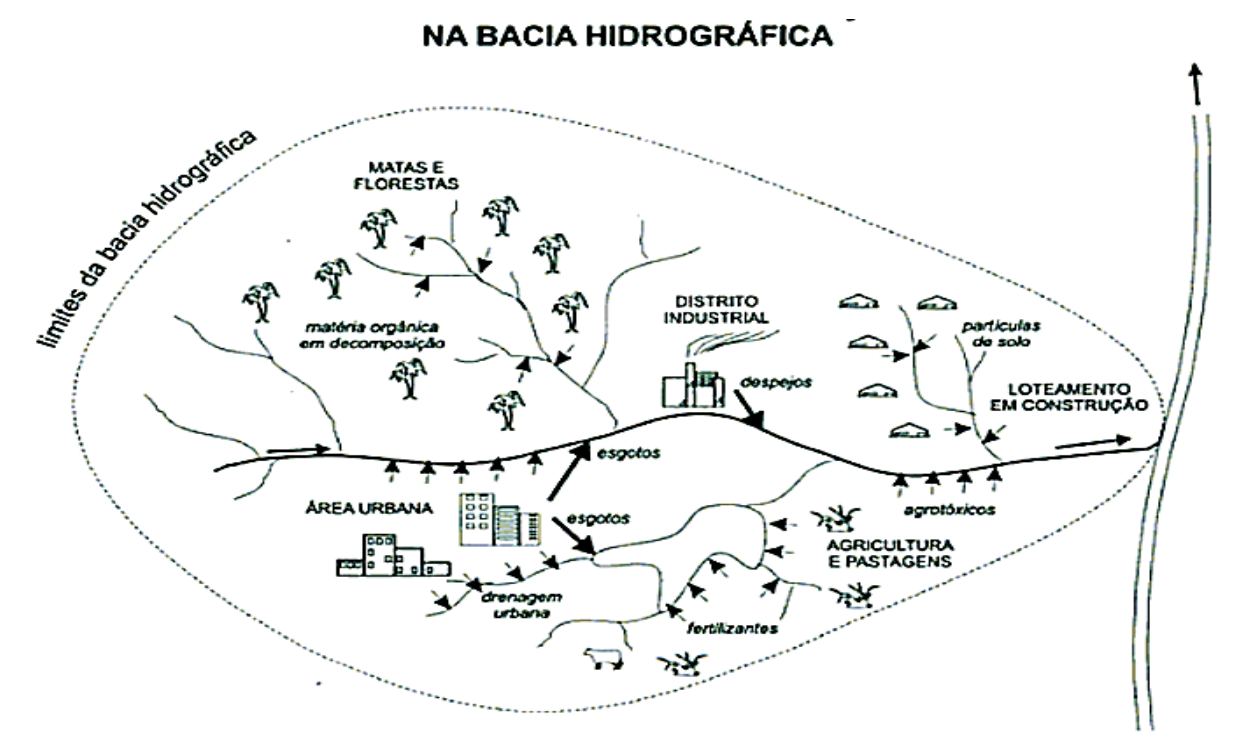

Figura 1 - Exemplos de inter-relações entre uso e ocupação do solo e focos alteradores da qualidade da água (VON SPERLING, 2005).

\subsubsection{Parâmetros de qualidade da água}

A água pode ter sua qualidade representada por meio de diversos parâmetros, os quais designam as principais características químicas, físicas e biológicas.

VON SPERLING (2005) cita três padrões de qualidade dos corpos hídricos brasileiros que são considerados referência para qualquer estudo e tomada de decisões:

- $\quad$ Padrão de Potabilidade: Portaria 518 (2004), (atualmente Portaria 2994 (2011) do Ministério da Saúde).

- $\quad$ Padrão de Corpos D’água: Resolução CONAMA 357 (2005) do Ministério do Meio Ambiente, e eventuais legislações estaduais. 
- $\quad$ Padrão de Lançamento: Resolução CONAMA 357 (2005), do Ministério do Meio Ambiente (atualmente Resolução 430 (2011)), e eventuais diretrizes e legislações estaduais.

Os padrões de qualidade das águas determinados na Resolução $\mathrm{n}^{\circ}$. 357/2005 do CONAMA estabelecem limites individuais para cada substância em cada classe de água. A classificação padronizada dos corpos de água possibilita que se fixem metas para atingir níveis de indicadores consistentes com a classificação desejada (HESPANHOL, 2009).

Os corpos hídricos de água doce de estudo do presente trabalho são classificados de acordo com o INEA como rios de classe II, sendo enquadrados na Resolução CONAMA 357/2005 com os seguintes padrões:

- DBO 5 dias a $20^{\circ} \mathrm{C}$ até $5 \mathrm{mg} / \mathrm{L} \mathrm{O}_{2}$;

- OD, em qualquer amostra, não inferior a $5 \mathrm{mg} / \mathrm{L} \mathrm{O}_{2}$;

- Fósforo total:

a) até 0,030 mg/L, em ambientes lênticos; e,

b) até $0,050 \mathrm{mg} / \mathrm{L}$, em ambientes intermediários, com tempo de residência entre 2 e 40 dias, e tributários diretos de ambiente lêntico;

- Ferro dissolvido $0,3 \mathrm{mg} / \mathrm{L} \mathrm{Fe}$;

- pH: 6,0 a 9,0.

Alguns indicadores de qualidade da água devida à sua importância e influência nos corpos hídricos serão discutidos a seguir.

\subsubsection{Indicadores de matéria orgânica na qualidade da água}

As inúmeras substâncias orgânicas presentes num efluente podem receber a denominação global de matéria orgânica. Esse material pode estar suspenso ou solúvel e ser classificado como biodegradável ou persistente (não biodegradável) (SANT'ANNA, 2013). 
Os principais componentes orgânicos são os compostos de proteína, os carboidratos, a gordura e os óleos, além da ureia, pesticidas e outros em menor concentração. Há uma grande dificuldade na determinação laboratorial dos diversos componentes da matéria orgânica nas águas, face á multiplicidade de formas e compostos que esta pode apresentar (VON SPERLING, 2005). Devido a essa dificuldade na determinação, são utilizados métodos indiretos que auxiliam na quantificação da matéria orgânica.

Entre os indicadores de matéria orgânica presente em corpos d'água, os mais usados são DBO e DQO (medição do consumo de oxigênio associado à oxidação das substâncias orgânicas presentes) e COT (medição do carbono orgânico).

\subsubsection{Oxigênio Dissolvido}

Pesquisadores têm frequentemente usado a concentração de oxigênio dissolvido (OD) e déficit de oxigênio dissolvido para avaliar a qualidade da água em diferentes baías e rios (KANNEL et al., 2007). O teor de oxigênio em águas naturais varia amplamente de acordo com processos biológicos, físicos e químicos.

A curva de variação do OD ao longo do rio é resultado de dois mecanismos (SANT'ANNA, 2013):

a. Consumo de oxigênio pelos microorganismos que, em decorrência da abundância de nutrientes (especialmente pelo lançamento de esgoto doméstico) nas proximidades do lançamento, multiplicam-se rapidamente e degradam a matéria orgânica presente na fase aquosa;

b. Reaeração natural, que é o mecanismo que repõe o oxigênio consumido para a biodegradação dos poluentes.

Os níveis de oxigênio dissolvido em água são bastante limitados se comparado aos níveis de oxigênio atmosférico. De acordo com GRASSI (2001), em águas 
frias, os níveis de oxigênio dissolvido em águas podem atingir cerca de 10 ppm (mg. $\left.\mathrm{L}^{-1}\right)$. Este valor pode ser considerado baixo se comparado com os níveis de oxigênio no ar, por exemplo, que são da ordem de 210.000 ppmv $^{2}$ (21\%). Assim sendo, mesmo quantidades moderadas de matéria orgânica pode resultar em uma diminuição significativa no oxigênio dissolvido presente em águas naturais. Esses níveis de oxigênio dissolvido flutuam sazonalmente, variando com a temperatura da água e com a altitude.

O mecanismo que proporciona a dissolução do oxigênio nas águas naturais é matematicamente descrito pela Lei de Henry, a qual estabelece que a concentração de saturação de um gás na água ocorre em função da pressão parcial do mesmo na atmosfera:

$$
\mathrm{C}_{\mathrm{SAT}}=\alpha \cdot \mathbf{p}_{\text {gás }}
$$

Onde:

$\alpha$ é uma constante que varia inversamente proporcional à temperatura

$\mathbf{p}_{\text {gás }}$ é a pressão exercida pelo gás sobre a superfície do líquido.

Quando a concentração de solubilidade na fase líquida é atingida, o fluxo de intercâmbio das moléculas da fase gasosa para a líquida é atingido, de modo a não ocorrer uma mudança global das concentrações. Esse equilíbrio dinâmico define a concentração de saturação $\left(\mathrm{C}_{\mathrm{s}}\right)$ do gás na fase líquida (VON SPERLING, 2007).

Os valores de solubilidade do oxigênio em água a várias temperaturas, a partir da ausência de salinidade estão apresentados na Tabela 1. 
Tabela 1 - Concentração máxima de oxigênio dissolvido de acordo com variação da temperatura. Fonte - EPA (2012).

\begin{tabular}{|c|c|c|c|}
\hline $\begin{array}{c}\text { Temperatura } \\
\left({ }^{\circ} \mathbf{C}\right)\end{array}$ & $\begin{array}{c}\text { OD } \\
(\mathbf{m g} / \mathbf{l})\end{array}$ & $\begin{array}{c}\text { Temperatura } \\
\left({ }^{\circ} \mathbf{C}\right)\end{array}$ & $\begin{array}{c}\text { OD } \\
(\mathbf{m g} / \mathbf{l})\end{array}$ \\
\hline 20 & 9.07 & 31 & 7.41 \\
\hline 21 & 8.90 & 32 & 7.28 \\
\hline 22 & 8.72 & 33 & 7.16 \\
\hline 23 & 8.56 & 34 & 7.16 \\
\hline 24 & 8.40 & 35 & 6.93 \\
\hline 25 & 8.24 & 36 & 6.82 \\
\hline 26 & 8.09 & 37 & 6.71 \\
\hline 27 & 7.95 & 38 & 6.61 \\
\hline 28 & 7.81 & 39 & 6.51 \\
\hline 29 & 7.67 & 40 & 6.41 \\
\hline 30 & 7.54 & 41 & 6.41 \\
\hline
\end{tabular}

Em relação ao consumo da matéria orgânica pelos microorganismos, esta ocorre nos vários tipos de oxidação da matéria orgânica suspensa (carbonácea e nitrogenada) e a decantada - que é representada pela camada de sedimentos decantados (responsáveis pela demanda bentônica de oxigênio). Estes fenômenos contribuem para o processo de desoxigenação dos corpos hídricos, tendo como consequência a ocorrência de uma curva de depleção de oxigênio, sendo esta curva alterada após o processo de reaeração natural.

A curva de reaeração é a entrada de oxigênio no corpo receptor por 3 principais mecanismos (DEZOTTI, 2008):

Difusão a nível molecular na interface gás- líquido

> Turbilhonamento (é uma difusão mais rápida que a molecular).

Geração in-situ de oxigênio pela ação da fotossíntese. 
A difusão molecular ocorre em ambientes sem correntezas. Há um incessante movimento das moléculas de oxigênio do meio concentrado para o de menor concentração.

O coeficiente da taxa de reaeração atmosférica $\left(\mathrm{K}_{2}\right)$ depende além da temperatura, da turbulência e mistura, e da existência de quedas d'água. Cursos d'água mais rasos e velozes tendem a possuir maior coeficiente de reaeração, devido respectivamente à maior facilidade de mistura ao longo da profundidade $\mathrm{e}$ à criação de maiores turbulências na superfície (VON SPERLING, 1996). Os níveis de OD em áreas abaixo de corredeiras, cachoeiras, ou vertedouros de barragens são normalmente mais elevados do que aqueles em trechos mais lentos.

Outra fonte importante de oxigênio nas águas é a fotossíntese das algas. A disponibilização de nutrientes favorece o aumento de algas, o que permite grande produção de OD, podendo ultrapassar a concentração de saturação. Este fato pode não ser benéfico para o corpo hídrico dependendo da quantidade de algas, apesar da alta concentração de OD. Segundo CHANG et al., (1988), apesar dos crescimentos densos de algas contribuírem com grandes quantidades de OD em lagoas durante o período de luz do dia (resultando em supersaturação de oxigênio), elas consomem quantidades substanciais de oxigênio durante a noite, causando condições anóxicas na madrugada.

Os animais aquáticos são os mais vulneráveis a níveis de OD baixo no início da manhã em dias quentes de verão, pois os fluxos de transmissão são baixos, a temperatura da água elevada e as plantas aquáticas não produzem oxigênio desde o pôr- do- sol (EPA, 2012).

A curva de oxigênio dissolvido pode ser entendida como uma resultante de duas curvas: a curva do consumo de oxigênio e a curva de reaeração (Figura 2). 


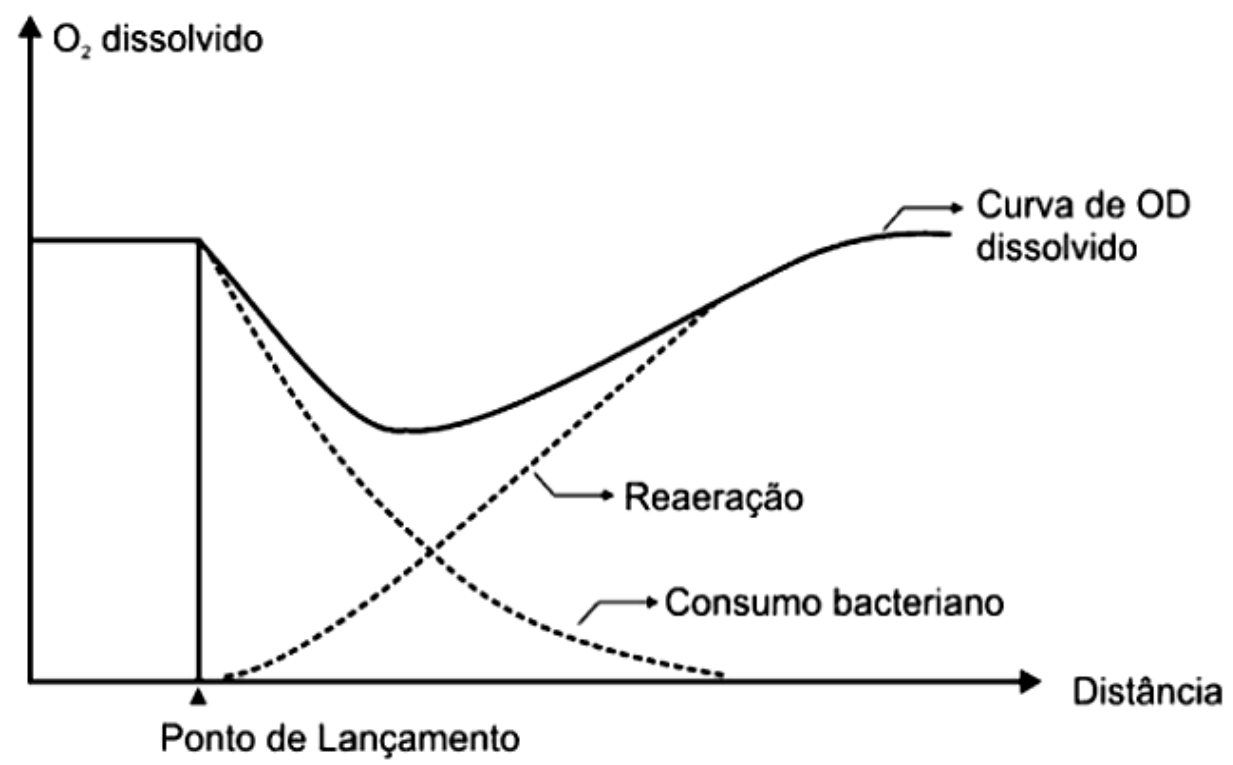

Figura 2 - Efeito do lançamento de um efluente sobre o OD de um curso d'água. Fonte. DEZOTTI (2008).

As transformações cíclicas e a decomposição biológica do material orgânico, aliados à ação de agentes naturais físicos (sedimentação dos sólidos em suspensão) e químicos, propiciam que as águas voltem a apresentar as características anteriores à poluição. Essa decomposição da matéria orgânica por microorganismos aeróbios corresponde a um dos mais importantes processos integrantes do fenômeno denominado autodepuração, o qual será influenciado também pela concentração e tipo do poluente. Esse processo é responsável pelo decréscimo nas concentrações de oxigênio dissolvido na água devido à respiração dos microorganismos, que por sua vez decompõem a matéria orgânica.

De acordo com VON SPERLING (1996), o mecanismo de autodepuração é como um fenômeno de sucessão ecológica, onde o processo de reestabelecimento pelo estágio inicial encontrado antes do lançamento de efluentes é realizado por mecanismos essencialmente naturais.

O processo de autodepuração de um corpo receptor ocorre em diferentes zonas (Figura3). Segundo DEZOTTI (2008) essas zonas podem ser divididas em:

$\checkmark$ Zona de degradação (zona de elevada turbidez)

$\checkmark$ Zona de decomposição ativa (zona mais nociva) 
$\checkmark$ Zona de recuperação (a concentração de OD aumenta gradualmente enquanto a concentração de sólidos suspensos diminui)

$\checkmark$ Zona de água límpida

É possível observar pelas curvas de oxigênio dissolvido do corpo receptor (Figura 3), que após determinado lançamento o déficit de oxigênio começa a sofrer alterações. Nas proximidades do ponto de lançamento ocorre proliferação de bactérias, neste ponto, a água pode ficar turva e os sólidos mais densos podem se acumular no leito do rio. O ponto no qual a curva de oxigênio passa por um valor mínimo (ponto crítico) corresponde ao ponto onde ocorre a maior concentração de biota menos demandante de oxigênio, onde os organismos que necessitam de oxigênio passam a desaparecer ou migrar para outros pontos. Segundo MELO (2006), ao longo do perfil de OD no corpo d'água em função do tempo, um ponto de fundamental importância é o ponto no qual o oxigênio assume seu valor mínimo. Nesse momento, tem-se a concentração crítica $(\mathrm{Cc})$ e o tempo crítico (tc). O valor da concentração crítica não deve ser inferior ao valor mínimo estabelecido pela legislação em função da classe do corpo d'água.

Por fim, o rio só consegue recuperar o nível de OD e se autodepurar quilômetros abaixo do ponto de lançamento.

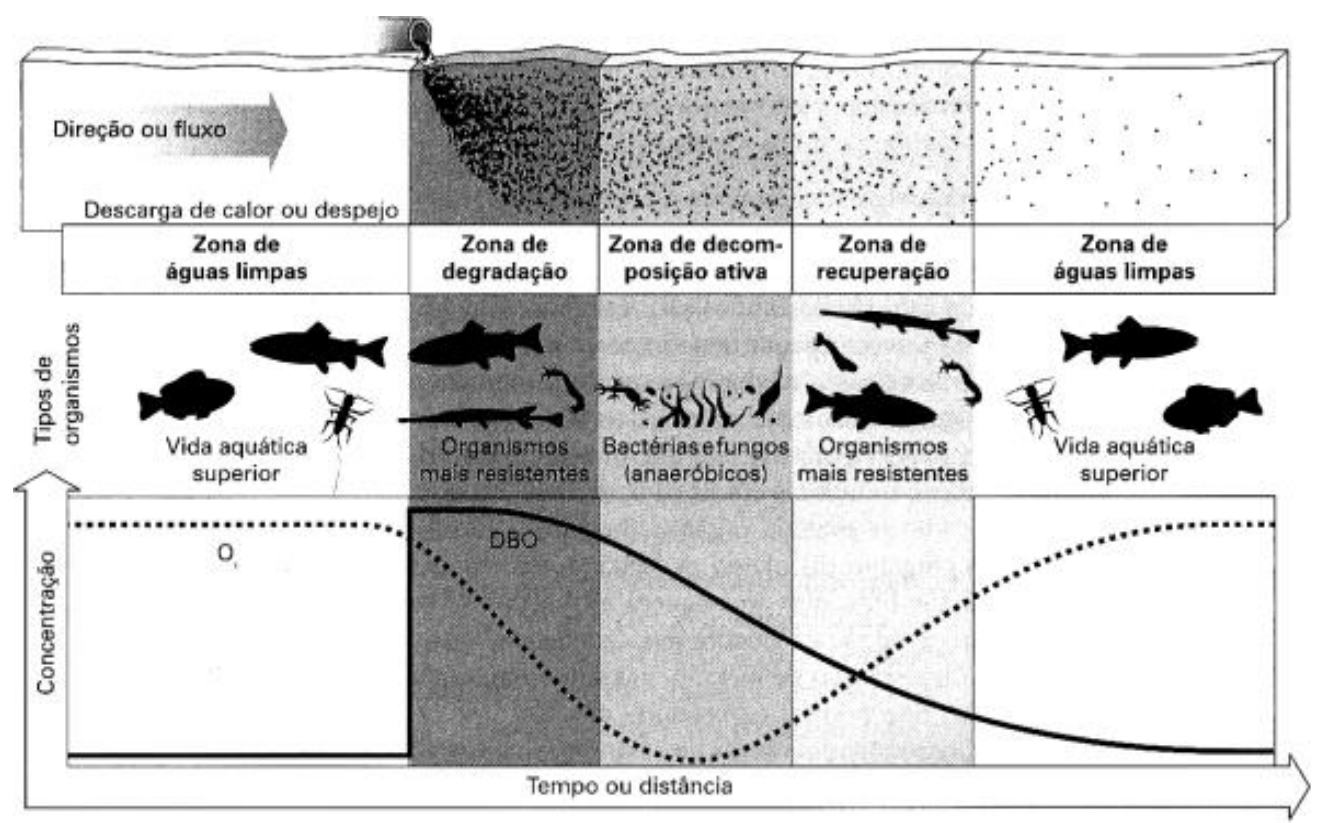

Figura 3 - Etapas da autodepuração. Fonte. (BRAGA et al., 2005). 
Uma das primeiras formulações matemáticas utilizadas para o cálculo do perfil de oxigênio dissolvido, após o lançamento de matéria orgânica no corpo hídrico e o tempo demandado para a autodepuração, foi proposta por Streeter e Phelps em 1925. Tal formulação passou a ser conhecida como o Modelo de Streeter - Phelps. Este modelo considera no balanço do oxigênio, apenas dois processos: o consumo de oxigênio, pela oxidação da matéria orgânica durante a respiração (desoxigenação), e a produção de oxigênio (reaeração), pela reaeração atmosférica através de duas equações diferenciais: uma modela a oxidação da parte biodegradável da matéria orgânica e a outra o fluxo de oxigênio proveniente da dinâmica da reaeração atmosférica. Essas equações são nomeadas equações de demanda bioquímica de oxigênio e equação de reaeração, respectivamente (BEZERRA, 2008).

Durante o processo de desoxigenação (K1), a cinética de reação da matéria orgânica se dá segundo uma reação de primeira ordem, onde a taxa de oxidação da matéria orgânica é tanto maior, quanto for a matéria orgânica disponível. O segundo fenômeno integrante desse balanço de oxigênio, a reaeração atmosférica (K2), representa a difusão de oxigênio atmosférico do ar para o líquido (MELO, 2006).

Devido principalmente a sua simplicidade conceitual, o Modelo de Streeter Phelps é até hoje o mais utilizado para a modelagem de DBO e OD, além de servir como base para modelos mais avançados disponíveis atualmente (MELO, 2006).

\subsubsection{Carbono}

Segundo LIBÂNIO, et al. (2000), os compostos orgânicos presentes em águas naturais são provenientes basicamente de duas fontes:

- Substâncias húmicas oriundas da decomposição de matéria orgânica de origem predominantemente vegetal.

- Atividades antrópicas, tais como, descargas de efluentes domésticos ou industriais, lixiviação de vias urbanas, e solos agriculturáveis. 
O carbono da matéria orgânica presente na água pode ser quantificado diretamente (medição do carbono orgânico) como carbono orgânico total (COT) ou indiretamente (medição do consumo de oxigênio para a sua oxidação) como demanda biológica de oxigênio (DBO) e demanda química de oxigênio (DQO).

\section{- Carbono Orgânico Total (COT)}

O carbono orgânico total em água doce origina-se da matéria viva e também como componente de vários efluentes e resíduos (CETESB, 2013). Sua presença na água é um indicador importante e útil do grau de matéria orgânica de um corpo hídrico.

O COT é obtido pela oxidação do carbono, portanto, é uma medida direta da diversidade de compostos orgânicos em vários estados de oxidação em uma amostra de água (PARRON, et al., 2011). A matéria orgânica carbonácea (baseada no carbono orgânico) divide-se em:

Classificação quanto à biodegradabilidade

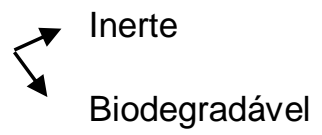

Adaptado de VON SPERLING (2005).

Em águas superficiais o teor de COT varia de 1 a $20 \mathrm{mg} / \mathrm{L}$, elevando-se até para $1000 \mathrm{mg} / \mathrm{L}$ nas águas residuárias. Desta forma, uma alteração significativa deste parâmetro constitui-se em um indicativo de novas fontes poluidoras e balizador das análises a serem realizadas, tais como, cor verdadeira, fósforo total, etc (LIBÂNIO, et al. 2000).

\section{- Demanda Bioquímica de Oxigênio (DBO)}

A demanda biológica de oxigênio (DBO) e a demanda química de oxigênio (DQO) indicam o consumo ou a demanda de oxigênio necessária para estabilizar a matéria orgânica presente, sendo a DBO definida como a quantidade de oxigênio necessária para a oxidação bioquímica enquanto a DQO corresponde à oxidação química (utiliza-se um oxidante químico- dicromato de potássio em meio ácido ácido sulfúrico). 
A medida da DQO raramente coincidirá com a medida da DBO, já que na medida da DQO há substâncias tanto biodegradáveis quanto substâncias nãobiodegradáveis, pois na determinação da DQO ambas substâncias são quimicamente oxidadas, como mostra a equação abaixo (DEZOTTI, 2008).

$$
\text { DQO } \text { Total }=\mathrm{DQO}_{\mathrm{BD}}+\mathrm{DQO}_{\mathrm{NBD}}
$$

Onde $\mathrm{DQO}_{\mathrm{BD}}$ corresponde ao consumo de oxigênio pelas substâncias biodegradáveis e $\mathrm{DQO}_{\mathrm{NBD}}$ corresponde ao consumo de oxigênio para a oxidação das substâncias não- biodegradáveis.

A demanda de oxigênio é exercida por substâncias orgânicas que são bioquimicamente oxidadas (DBO carbonácea), assim como também compostos nitrogenados (amônia, nitrito, etc), que são oxidados no teste mais tarde, exercendo a DBO nitrogenada. A oxidação total da matéria orgânica (mineralização) tem como resultado das reações produtos finais simples (como por exemplo, $\mathrm{CO}_{2}, \mathrm{H}_{2} \mathrm{O}, \mathrm{NO}_{3}$ ).

$$
\begin{aligned}
& \text { Matéria orgânica (COHNS) + } \mathrm{O}_{2}+\text { Bactérias } \rightarrow \mathrm{CO}_{2}+\mathrm{H}_{2} \mathrm{O}+\mathrm{NH}_{3}+ \\
& \text { Outros produtos finais + Energia }
\end{aligned}
$$

(COHNS representam esquematicamente a matéria orgânica composta por carbono, oxigênio, hidrogênio, nitrogênio e enxofre) (VON SPERLING, 2005).

Uma variedade de matéria orgânica pode causar a poluição de rios. Fontes de DBO podem ocorrer tanto por origem natural, como folhas e detritos de madeira; plantas e animais mortos; estrume animal; como por origem antropogênica, por exemplo, estações de tratamento de águas residuais, efluentes de planta de papel e celulose, de plantas de processamento de alimentos; falha de sistemas sépticos, escoamento de águas pluviais urbanas entre outras (EPA, 2012).

Se o teste de DBO for conduzido por um tempo maior, este atingirá um valor designado plateau, que seria referente à oxidação completa dos poluentes biodegradáveis em análise. Esse valor é a DBO final (ultimate) (DBOu). 


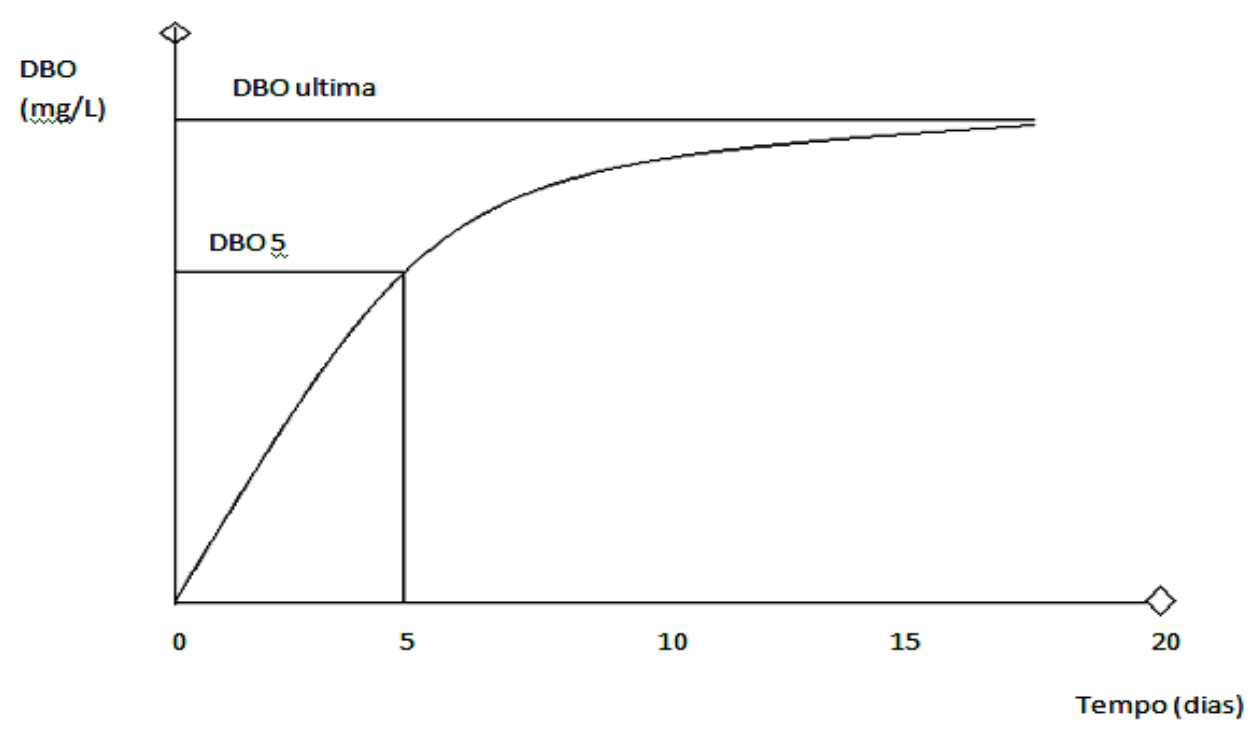

Figura 4 - Evolução da DBO no decorrer do tempo.

Com base na Figura 4 que ilustra o resultado típico de DBO (representada por y) ao longo do tempo, um modelo simples segundo SANT'ANNA (2013) pode ser usado para representar a variação de y com o tempo. Este modelo e outros seguem as seguintes hipóteses:

$\checkmark$ O consumo da matéria orgânica biodegradável (substrato S) segue uma cinética de primeira ordem.

$\checkmark$ Há proporcionalidade entre consumo de oxigênio e consumo da matéria orgânica biodegradável.

Com base na primeira hipótese, pode-se escrever (SANT'ANNA, 2013):

dS/dt $=-$ K.S

Com a condição inicial: $\mathrm{t}=0, \mathrm{~S}=\mathrm{S}_{0}$

K= cte de biodegradação da matéria orgânica.

A degradação desses poluentes orgânicos pode ser caracterizada como um processo de respiração, onde os poluentes são oxidados a $\mathrm{CO}_{2}$. Durante o metabolismo aeróbio, as moléculas dos poluentes podem ser oxidadas, proporcionando um maior rendimento em ATP, permitindo maior energia, logo, 
maior multiplicação celular. Esse trabalho é realizado principalmente por bactérias.

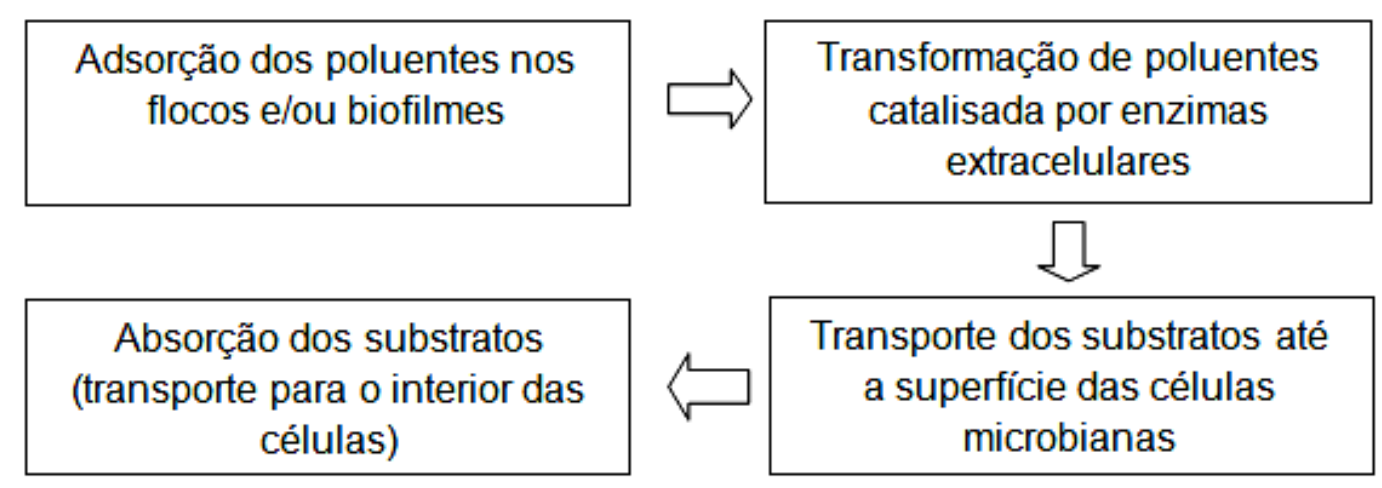

Figura 5 - Etapas envolvidas na remoção microbiana de poluentes orgânicos. Fonte. SANT'ANNA (2013).

Deve-se observar que o parâmetro DBO não fornece o total de matéria orgânica que está presente em um efluente, mas é muito útil do ponto de vista ambiental, pois este parâmetro nos possibilita saber o quanto de oxigênio dissolvido será consumido pelo corpo receptor de acordo com o efluente lançado.

\subsubsection{Sólidos Suspensos}

Nos estudos de controle de poluição das águas naturais, caracterização de esgotos e de efluentes industriais, a determinação das concentrações das frações de sólidos se classifica em relação ao tamanho das partículas e à sua natureza. Em relação ao tamanho, este pode ser determinado através de filtração, onde os sólidos suspensos são considerados não filtráveis e sólidos dissolvidos os filtráveis. Já a classificação quanto á natureza (características químicas) é determinada em função da volatilidade. De maneira geral, são considerados como sólidos dissolvidos aqueles com diâmetro inferior a $10^{-3}$ micrômetros, como sólidos coloidais aqueles com diâmetro entre $10^{-3}$ e $10^{0}$ micrômetros, e como sólidos em suspensão aqueles com diâmetro superior a $10^{\circ}$ micrômetros (Figura $6)$. 
DISTRIBUIÇĀO DOS SÓLIDOS

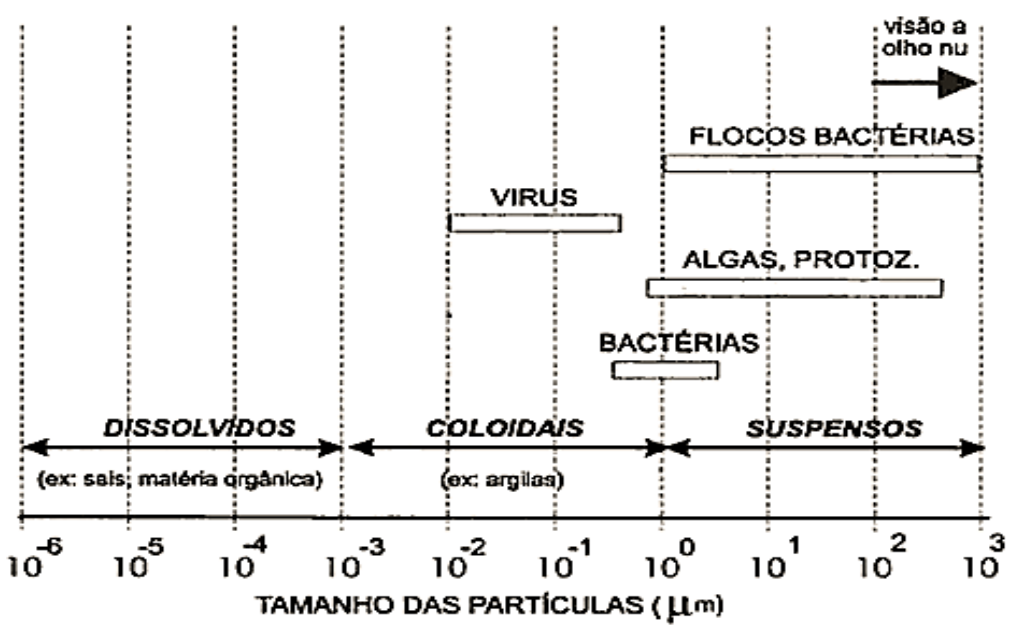

Figura 6 - Classificação e distribuição dos sólidos em função do tamanho. Fonte. VON SPERLING (2005).

Os sólidos suspensos apresentam uma grande variedade de materiais, incluindo lodo, vegetal em decomposição e matéria animal, resíduos industriais e esgotos EPA (2014). Segundo BRITO (2010), esse transporte dos sólidos ocorre via tributário, precipitação, sedimentação, resuspensão e escoamento superficial.

Para CARVALHO (1994), os sólidos ao serem transportados podem causar pelas partículas em suspensão a degradação da qualidade das águas tanto para o uso humano (como consumo, recreação, etc.) como também contribuir para a redução da penetração da luz solar, o que favorece a redução da fotossíntese, necessária aos corpos d'água. Segundo KANNEL, et al. (2007), os sólidos em suspensão maiores podem bloquear a luz, resultando em morte de plantas, que depois de decompostas por bactérias resulta na demanda de oxigênio, afetando os peixes.

Em regimes de escoamento lentos pode ocorrer sedimentação e origem a depósitos. Segundo SANT'ANNA (2013), aumentos bruscos de velocidade da água podem relocar em suspensão esse material que passa a ser degradado por bactérias aeróbias, gerando assim, déficits de $\mathrm{OD}$, extremamente danosos à fauna aquática. 


\subsubsection{Metais}

Muitos elementos-traço também são determinados em águas. Alguns exemplos são Al, Sb, As, Cd, Cr, Cu, Pb, Hg, Se, Ag, Zn, dentre outros.

Os elementos-traço dissolvidos na água ou presentes no material particulado suspenso são em sua grande maioria tóxicos. Arsênio, cádmio, cromo, chumbo, mercúrio e prata podem estar dissolvidos na água e acumular em seres vivos. De acordo com VON SPERLING (2005), as concentrações desses metais em corpos d'água naturais são pequenas. Como forma constituinte responsável, temos os sólidos em suspensão e os sólidos dissolvidos.

Quando encontrados em concentrações elevadas, esses elementos podem ter origem antropogênica. Para FROEHNER et al (2008), alterações na presença de metais podem estar associadas ao lançamento indiscriminado de esgotos domésticos e industriais.

\subsection{Contaminação Orgânica}

Todos os compostos ou contaminantes orgânicos contêm carbono em combinação com um ou mais elementos. Segundo PARRON et al (2011), a lista de compostos orgânicos presentes em amostras de água cresceu de aproximadamente 200, em 1975, para a ordem de milhões, atualmente, e está constantemente aumentando.

O lançamento de esgotos domésticos é um dos principais vetores de contaminação para ambientes aquáticos, sendo o grau desta contaminação consequência das concentrações e tipos de contaminantes presentes. Segundo VON SPERLING (2005), os esgotos domésticos contêm aproximadamente 99,9\% de água. A fração restante inclui sólidos orgânicos e inorgânicos, suspensos e dissolvidos, bem como microrganismos. É devido a essa fração de $0,1 \%$ que há necessidade de se tratar esses esgotos.

No Brasil, segundo o Ministério das Cidades, cerca de 60 milhões de brasileiros (9,6 milhões de domicílios urbanos) não são atendidos pela rede de coleta de esgoto e, destes, aproximadamente 15 milhões (3,4 milhões de 
domicílios) não têm acesso à água encanada. Ainda mais alarmante é a informação de que, quando coletado, apenas $25 \%$ do esgoto são tratados, sendo o restante despejado "in natura", ou seja, sem nenhum tipo de tratamento, nos rios ou no mar (MINISTÉRIO DO MEIO AMBIENTE, 2013).

Outro meio potencialmente causador de contaminação por esgotos são as precipitações de chuva, podendo ocasionar o transbordamento de esgotos sanitários e transbordamentos de esgotos combinados. LEHNER et al. (1999) citam que o transbordamento por esgoto sanitário ocorre muitas vezes por causa de vazamentos e rachaduras, tornando-se sobrecarregados em tempos de chuvas. Já o transbordamento de esgotos combinados ocorre quando há deságue no sistema de esgoto combinado (sistemas que recebem águas pluviais, as descargas de esgotos sanitários de residências e empresas, e descargas de águas residuais provenientes de instalações industriais e de transporte de tudo através de um único tubo) excedendo a capacidade de tratamento e armazenamento do sistema de esgoto. Nesse ponto, este fluxo de resíduos combinado transborda em riachos, rios, lagos ou estuários através de emissários designados geralmente sem tratamento.

Assim como os esgotos domésticos, os industriais também introduzem matéria orgânica nos sistemas aquáticos. Essa matéria orgânica tem características biodegradáveis, mas, entre as formas de compostos orgânicos, podem entrar as formas não biodegradáveis (pesticidas halogenados, solventes aromáticos, detergentes, etc.), tendo como principal característica a permanência no ambiente por muito tempo (meses/anos). O tempo de permanência dos poluentes biodegradáveis é relativamente curto (dias), sendo necessário em muitos casos segundo PARRON et al. (2011), a identificação apenas em concentrações baixas.

Os poluentes orgânicos emergentes, também chamados de poluentes emergentes, são definidos como compostos químicos encontrados no meio ambiente que ainda não possuem legislação regulatória ou que ainda não são geralmente monitorados, porém apresentam risco à saúde ambiental e humana. Os riscos estão diretamente associados ao sistema endócrino e reprodutivo humano e animal. A entrada desses compostos no meio ambiente é contínua, oriunda de 
processos industriais, descarte de produtos comerciais ou ainda por sua excreção na forma não metabolizada ou metabolizada (da SILVA e COLLINS, 2010). Algumas classes de poluentes emergentes são antibióticos, contraceptivos, agrotóxicos, entre outros.

\subsection{Poluição urbana: escoamento superficial}

A poluição aquática através do escoamento de áreas desenvolvidas ocorre quando as águas pluviais carreiam uma grande variedade de contaminantes. Percebe-se que tanto o uso da terra quanto os fatores sazonais desempenham um papel importante na influencia da qualidade dos mananciais.

Como escoados podemos citar as estradas, estacionamentos, canteiros de obras, gramados, locais inadequados de despejo de lixos, áreas com acúmulo e restos de vegetação e outras superfícies em nossas cidades e subúrbios.

A principal razão para que as águas pluviais urbanas continuem a ser um colaborador tão importante para a poluição da água é o fato de que na maioria das áreas, as águas pluviais não recebem tratamento antes de entrarem em massas de água. O sistema de coleta de esgotos de tempestades apenas recolhe o esgoto urbano e descarrega-o diretamente para o rio, lagoa, ou lago mais próximo (LEHNER et al., 1999).

\subsubsection{As causas da poluição por águas pluviais}

O problema da poluição de águas pluviais tem dois componentes principais: o aumento do volume e da velocidade do escoamento superficial e a concentração de poluentes. Esses componentes em conjunto podem causar alterações na qualidade da água, resultando em problemas como perda ou até extinção de habitat, aumento das inundações, diminuição da diversidade biológica aquática, e aumento da sedimentação e erosão.

Em áreas urbanas, a criação de uma cobertura impermeável e ausência de vegetação potencializam a redução da infiltração. Segundo ERICKSON, et al. 
(2013), o aumento de superfície impermeável aumenta o coeficiente de escoamento superficial (relação do volume da chuva com o volume de escoamento). Esse aumento da impermeabilidade também eleva o fluxo de cheias. LEHNER et al., (1999), verificaram em seu trabalho os limites de impermeabilidade, e, mostraram que quando a cobertura impermeável atinge entre 10 e 20 por cento da área de uma bacia hidrográfica, o estresse ecológico torna-se claramente aparente. Este fator potencializa o poder erosivo da água que flui através da superfície da terra.

LEE et al. (2000), avaliou áreas com poucos hectares porém com grande cobertura impermeável, e áreas de grandes hectares, porém com menor área de impermeabilização. O que observou foi que em áreas da bacia com mais de $80 \%$ de cobertura impermeável, houve maior pico de concentração de poluentes. $\mathrm{O}$ autor caracterizou a magnitude da taxa de carregamento em massa dos componentes em relação à área de ocupação (locais com maiores áreas de impermeabilização do solo) na ordem de: bacia hiodrográfica de alta densidade residencial > bacia de baixa densidade residencial > bacia industrial > bacia urbana subdesenvolvida.

O escoamento urbano foi identificado como uma fonte chave na elevação das concentrações de elementos (como por exemplo, fósforo e nitrogênio), podendo enriquecer córregos, lagos, reservatórios e estuários. Essencialmente, qualquer poluente depositado ou derivado de uma atividade sobre a superfície da terra, provavelmente vai acabar no escoamento de águas pluviais, com alguma concentração. No entanto, existem certos poluentes que são consistentemente mais propensos a resultar na degradação de um corpo hídrico. Estes poluentes que ocorrem mais frequentemente podem ser agrupados em várias categorias, incluindo nutrientes, sedimentos, metais pesados, hidrocarbonetos, aditivos de gasolina, patógenos, herbicidas e pesticidas (CLAR et al., 2004).

Podemos destacar algumas substâncias prioritárias contidas em águas pluviais, entre elas, metais como $\mathrm{Cd}, \mathrm{Cu}, \mathrm{Pb}$ e $\mathrm{Zn}$, além de compostos orgânicos, ambos como componentes que podem provocar a contaminação de corpos receptores (ZGHEIB et al., 2012), (ERICKSON et al., 2013), (LEHNER et al., 1999). Os principais contaminantes para águas pluviais que causam preocupação 
podem ser agrupados em sete categorias. A Tabela 2 a seguir lista as categorias e fornece exemplos.

Tabela 2 - Categorias dos principais componentes em águas de escoamento pluvial. Fonte - Adaptado de LEHNER et al. (1999).

\begin{tabular}{|c|c|}
\hline Categoria & Exemplos \\
\hline $\begin{array}{c}\text { Metais dissolvidos } \\
\text { Substâncias químicas } \\
\text { orgânicas }\end{array}$ & $\begin{array}{c}\text { Pesticidas, óleo, gasolina, graxa } \\
\text { arsênio }\end{array}$ \\
\hline Patógenos & Vírus, bactérias, protozoários \\
\hline Nutrientes & Nitrogênio, fósforo \\
\hline $\begin{array}{c}\text { Demanda bioquímica de } \\
\text { oxigênio }\end{array}$ & $\begin{array}{c}\text { Folhas caídas, dejetos humanos } \\
\text { e animais }\end{array}$ \\
\hline Sedimento & solo \\
\hline Sais & Cloreto de sódio, cloreto de \\
cálcio
\end{tabular}

Essa liberação de descargas de águas pluviais pode contribuir para a sedimentação e contaminação das águas, já que segundo ZGHEIB et al. (2012), a maioria das substâncias de águas prioritárias de águas pluviais é ligada às partículas. Á respeito da fração mais fina desses sedimentos, as argilas, através de processos de adsorção acabam sendo os transportadores de outros poluentes além dos metais, como fertilizantes, entre outros tóxicos (BELOTTI, 2011).

A chuva e o escoamento aumentam também a presença de patógenos microbianos. Concentrações de coliformes fecais são geralmente maiores imediatamente após tempestades, indicando que uma grande percentagem de coliformes fecais é um resultado do escoamento de águas pluviais (ERICKSON et al., 2013). Como parte do Programa de Escoamento Urbano Nacional, citado pelo mesmo autor, foram avaliados coliformes fecais em 17 locais nos EUA, para 156 
eventos de tempestade, e com base nos resultados, concluiu-se que as bactérias coliformes em esgoto urbano podem ultrapassar critérios de qualidade da água durante e após os eventos de tempestade. Nos meses mais quentes, as concentrações foram aproximadamente 20 vezes maiores do que os meses frios. Como consequência, esse escoamento de águas pluviais pode levar ao fechamento de praias para banho e pode aumentar o custo do tratamento de água potável em reservatórios de abastecimento de água (CLAR et al., 2004).

A. LIU et al. (2013) citam a investigação de Miguntanna (2009) sobre os nutrientes de águas pluviais. O fósforo está intimamente associado com a carga dos sólidos fixos, que é fortemente aderida à superfície e exige eventos de elevada energia cinética para uma maior remoção. Isso significa segundo o autor, que uma maior quantidade de fósforo é escoada por eventos com altas taxas de precipitação, devido à energia cinética superior e uma maior duração. S. CARROLL et al. (2013), sugerem que o uso da terra desempenha o papel principal na influência dos poluentes, como o nitrogênio e ferro, enquanto que a variação sazonal tem um impacto significativo na entrada de fósforo para os corpos d'água.

Após grandes eventos de tempestades, algumas fontes de demanda de oxigênio tais como resíduos de animais e vegetação em decomposição (fontes naturais) ou óleos e graxas (fontes antrópicas), passam a ser transportadas, exigindo alta quantidade de oxigênio do corpo aquático receptor.

As partículas que sofrem desagregação do solo e são arrastadas por escoamento superficial difuso para um corpo d'água receptor, são um dos principais problemas, pois importantes alterações podem ocorrer, dentre as quais sua gradual colmatação e por consequência, a redução da capacidade de descarga líquida.

\subsubsection{Influência da precipitação}

Algumas características dos eventos de precipitação devem ser levadas em consideração ao avaliar a situação ambiental de determinado corpo hídrico; entre 
elas, destaca-se a intensidade da precipitação e os dias secos antecedentes ao evento de chuva.

A. LIU et al., (2013) atribuem uma maior concentração de poluentes nas águas pluviais durante maiores precipitações à energia cinética relativamente mais elevada de eventos de alta intensidade de precipitação, resultando em mais poluentes transportados.

As regiões áridas e semi-áridas geralmente passam por períodos mais secos, onde os poluentes se acumulam a partir de diferentes fontes e, posteriormente, o escoamento em concentrações mais elevadas durante os eventos de tempestade (CLAR et al., 2004).

\subsection{Sub-bacia hidrográfica da Lagoa Rodrigo de Freitas}

A bacia hidrográfica pode ser considerada um ente sistêmico. É onde se realizam os balanços de entrada proveniente da chuva e saída de água através do exutório, permitindo que sejam delineadas bacias e sub-bacias. Todas as áreas urbanas, industriais, agrícolas ou de preservação fazem parte de alguma bacia hidrográfica. Pode-se dizer que, no seu exutório, estarão representados todos os processos que fazem parte do seu sistema. O que ali ocorre é consequência das formas de ocupação do território e da utilização das águas que para ali convergem (PORTO, 2008).

A cidade do Rio de Janeiro, pertencente à bacia hidrográfica do Atlântico Sul (trecho leste), pode ser dividida em três sub-bacias principais: sub-bacia da Baía de Sepetiba, sub-bacia da Baía de Guanabara e sub-bacia de Jacarepaguá e da Zona Sul. A área de estudo do presente trabalho está inserida na sub-bacia hidrográfica da Lagoa Rodrigo de Freitas, pertencente à sub-bacia da Zona Sul (Figura 7), e será referida neste, como apenas Bacia Hidrográfica da Lagoa Rodrigo de Freitas (TECHNO-BIO, 2012). O clima da cidade é do tipo tropical, quente e úmido, com variações locais, devido às diferenças de altitude, vegetação e proximidade do oceano. 


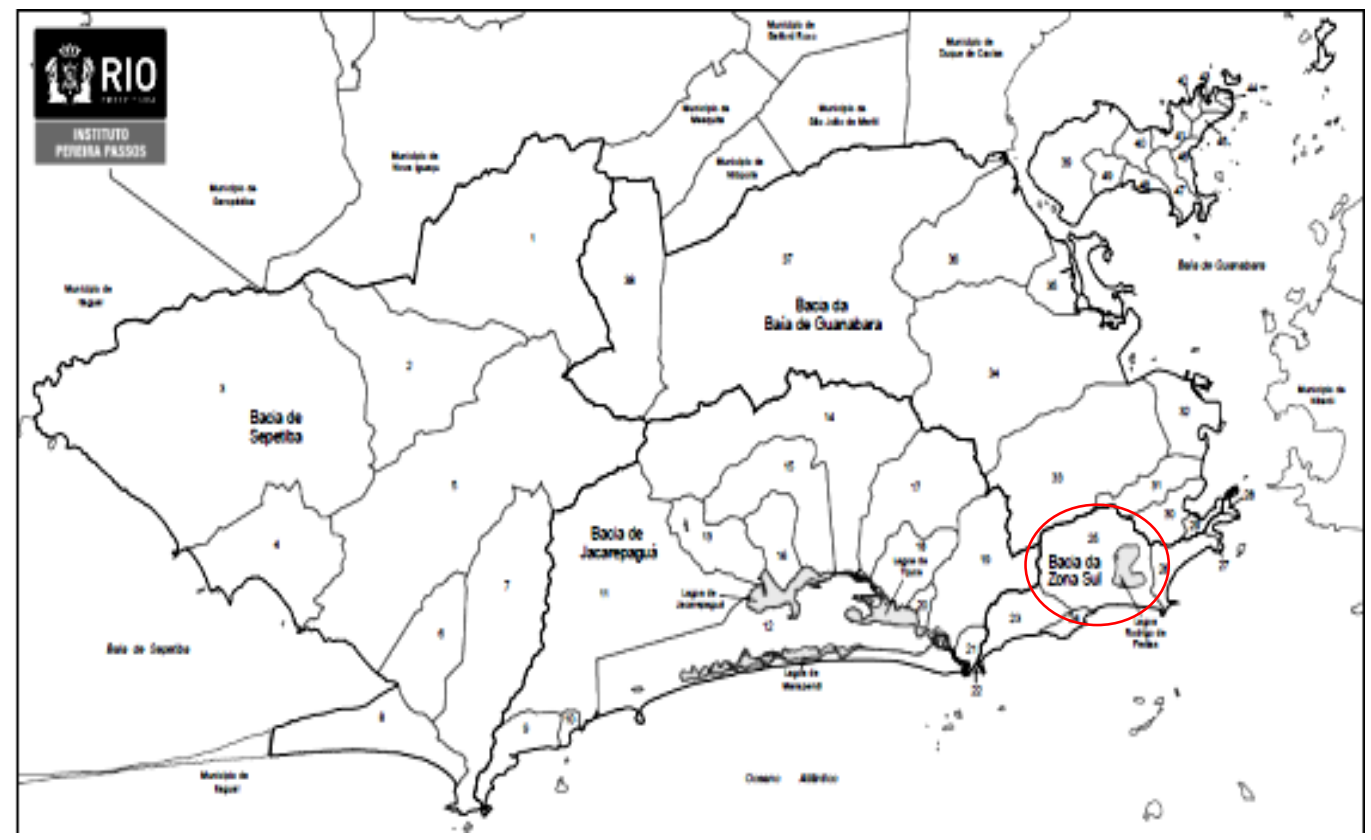

Figura 7 - Principais Bacias e Sub-bacias da cidade do Rio de Janeiro. Em destaque, a localização da Bacia Hidrográfica da Lagoa Rodrigo de Freitas. Fonte. RIO - ÁGUAS (2013).

A bacia Hidrográfica da Lagoa Rodrigo de Freitas abrange os bairros de Ipanema, Lagoa, Humaitá, Jardim Botânico e Gávea e drena as águas da vertente sudeste da Serra da Carioca, no maciço da Tijuca, apresentando uma área de cerca de $24 \mathrm{~km}^{2}$ (LOUREIRO, 2006).

Por estarem situadas em áreas densamente habitadas na faixa litorânea, as lagoas costeiras podem ser colocadas, entre os sistemas mais impactados pelas atividades antrópicas, destacando-se o lançamento de efluentes domésticos e industriais in natura (DOMINGOS et al., 2012). A drenagem da área de entorno da Lagoa influencia na qualidade de suas águas através do recebimento de águas pluviais e fluviais. Sua área de entorno é formada por três rios principais (Rios Cabeça, dos Macacos e Rainha), onde o Rio dos Macacos e o Rio Cabeça desembocam na Lagoa através de um único canal denominado das Tábuas nas proximidades da ilha do Piraquê, através do canal da Rua General Garzón.

Assim como outras lagoas costeiras do Estado do Rio de Janeiro, a Lagoa Rodrigo de Freitas tem despertado interesse de estudiosos, devido aos acentuados 
fenômenos naturais como estagnação e deterioração da qualidade de suas águas, exalação de gases, assoreamento e grandes mortandades de peixes (RIO ÁGUAS, 2010).

\subsubsection{Lagoa Rodrigo de Freitas}

A Lagoa Rodrigo de Freitas possui um espelho d'água de $2,2 \mathrm{~km}^{2}$ e volume de aproximadamente $6.200 .000 \mathrm{~m}^{3}$ (DOMINGOS, P. et al., 2012). É regulamentada como uma Área de Proteção Permanente (APP) pela Lei Orgânica do Município do Rio de Janeiro conforme artigo 463 (Lei Orgânica do município do Rio de Janeiro, 2008), destacando-se na região de estudo, a presença das áreas especiais de conservação ambiental (Figura 8), do Parque Nacional da Tijuca, Jardim Botânico e Parque da Cidade, entre outras, inseridas e ocupando parte das bacias de drenagem dos rios Cabeça, dos Macacos e Rainha (RIO - ÁGUAS, 2010).

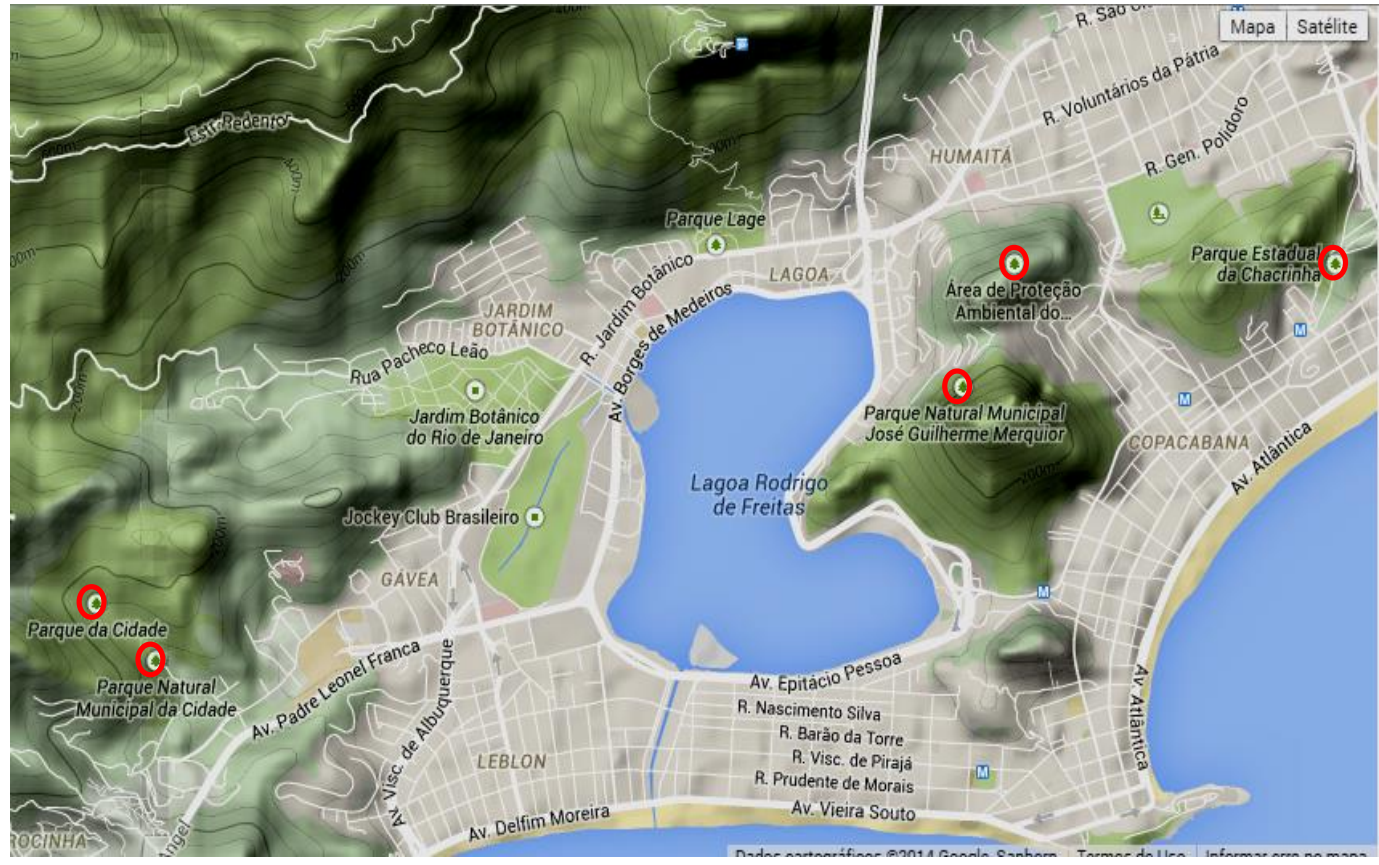

Figura 8 - Em destaque (em vermelho) áreas de conservação ambiental próximas á Lagoa Rodrigo de Freitas. Fonte. GEORIO (2014).

A falta de planejamento urbanístico, principalmente durante a ocupação em torno da Lagoa, causou sérios problemas ainda hoje presentes. A impermeabilização do solo no seu entorno devido à cobertura da malha urbana 
causa escoamentos superficiais acelerados, provocando aumento do volume das águas pluviais que serão drenadas e um maior transporte de sedimentos. Como consequência, podem ocorrer enchentes e assoreamento dos sistemas de drenagem e da própria Lagoa.

Os processos de aterramento em torno da Lagoa durante o início da ocupação urbana contribuíram para a redução do espelho d'água em cerca de $40 \%$ da área original (MACHADO, 2009), tendo-se como consequência, uma perda da vegetação e da fauna local. A Figura 9 permite observar os sucessivos aterros que ocorreram ao longo do tempo, ocasionando alterações no espelho d'água original.

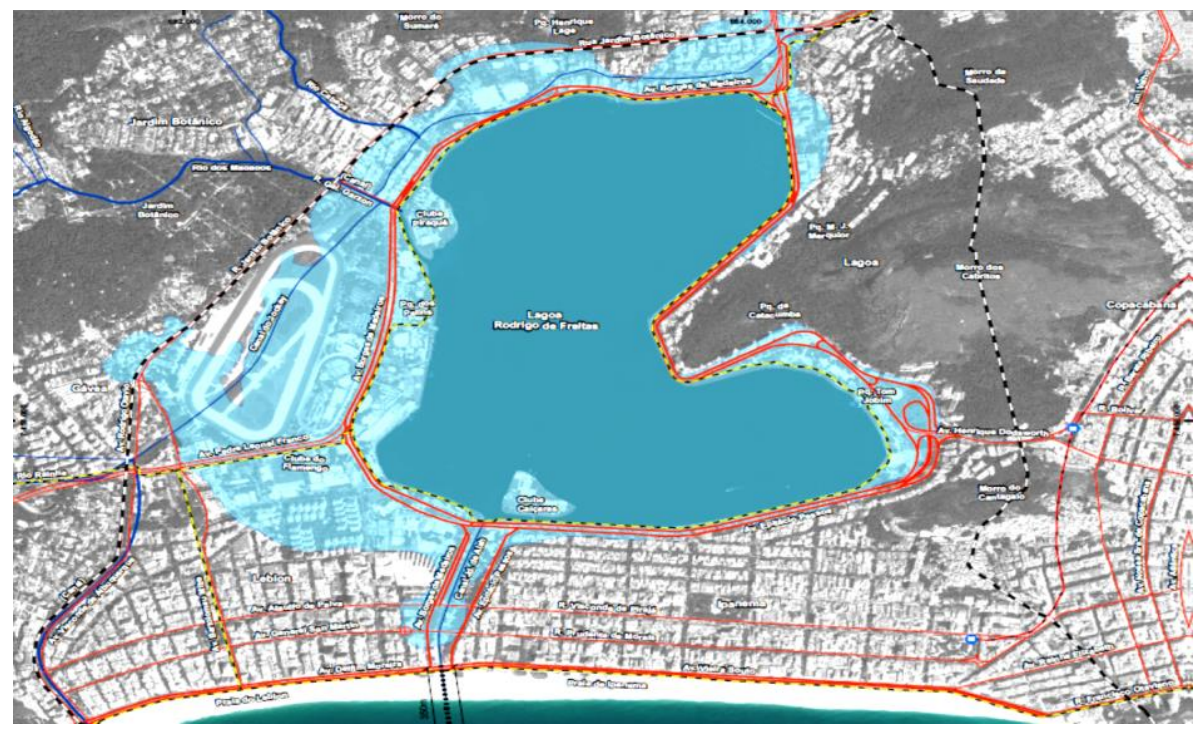

Figura 9 - Espelho d'água original (em azul claro) e atual (em azul escuro) da Lagoa Rodrigo de Freitas. Fonte. TECHNO-BIO (2012).

A Lagoa Rodrigo de Freitas (ao longo do texto abreviada LRF) era originalmente uma enseada aberta ao oceano sobre a qual diferentes intempéries foram moldando sua atual configuração, com destaque para os processos geológicos de formação de seu cordão arenoso, originado do carreamento de areia por correntes costeiras. De acordo com LOUREIRO (2006), até 1921 a Lagoa comunicava-se com o mar através de um canal natural instável, e sua embocadura permanecia obstruída por uma barra arenosa, exceto durante poucos dias por ano. 
Atualmente, a ligação da Lagoa com o mar é realizada pelo Canal do Jardim de Alah. Este Canal artificial possui 800m de comprimento, largura entre 10 e 18 metros e cota de fundo de - 0,7m (DOMINGOS, P. et al., 2012). De acordo com TECHNO-BIO (2012), o Canal opera de forma ineficiente devido ao seu tamanho subdimensionado em comparação ao volume da lagoa, e ao fato de ser sistematicamente obstruído por areias transportadas pelas ações das correntes costeiras (a elas associada à ação dos ventos), razão pela qual necessita ser permanentemente dragado. Para WEERELT et al. (2012), a LRF é então classificada como uma lagoa sufocada devido ao tempo de residência da água neste ecossistema, havendo pouca troca de água com o mar.

Nesse aspecto, a entrada de água do mar na Lagoa Rodrigo de Freitas tornase pouco significativa, não só em virtude da estreita largura do Canal de Jardim de Alah e do assoreamento do mesmo, mas também pelo nível da Lagoa, mais elevado que o mar. As exceções são as ocasiões em que as marés coincidem com grandes amplitudes e o canal encontra-se desassoreado (DOMINGOS, P. et al., 2012).

Essas trocas de água do mar com a lagoa e a drenagem das águas da bacia são controladas por comportas, sendo esta operação realizada pela Secretaria de Obras, através da Fundação Rio - Águas.

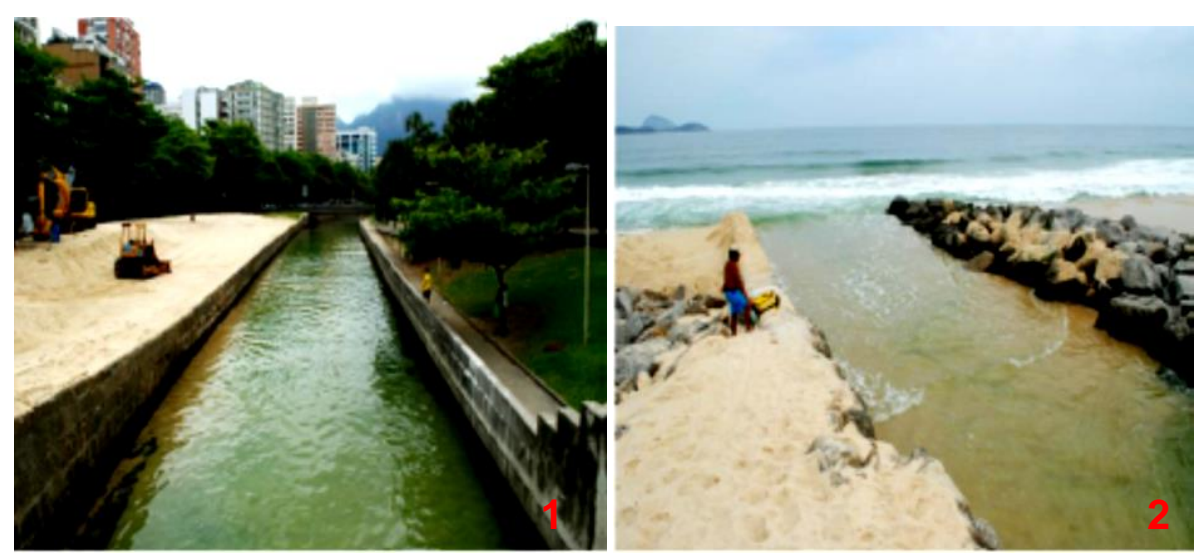

Figura 10 - Aspecto do Canal do Jardim de Alah (1) e sua embocadura na praia (2). É possível perceber a areia depositada no fundo do canal em ambas as fotos. Fonte. TECHNO-BIO (2012). 


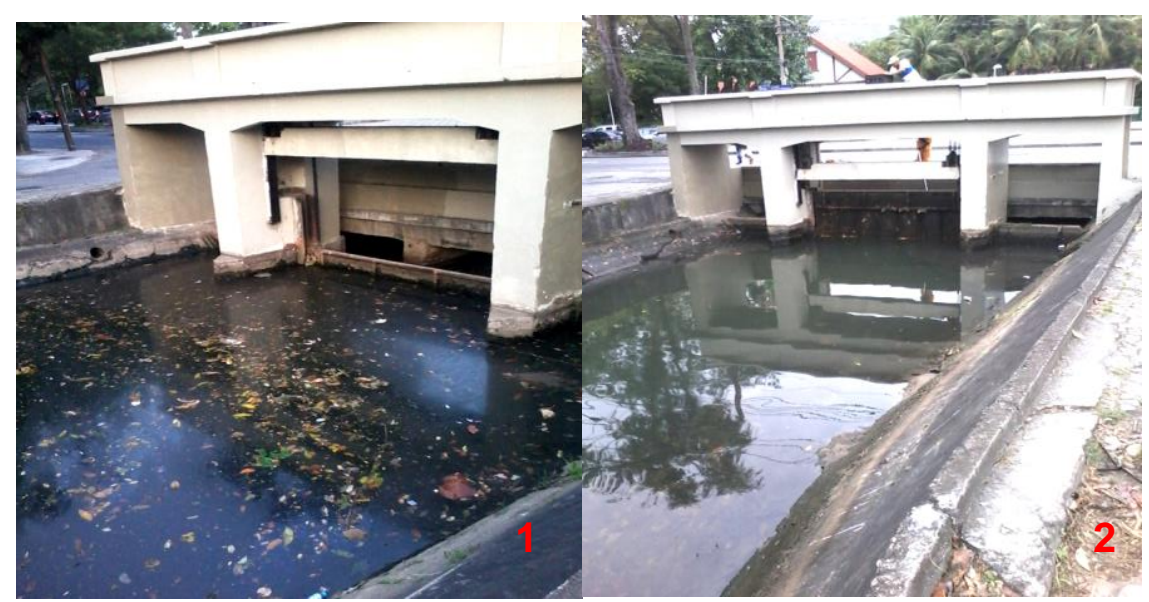

Figura 11 - Comporta da Rua Gal. Garzón. Comporta fechada (1); Comporta sendo aberta manualmente por funcionários da Prefeitura (2).

\subsubsection{Caracterização hidrológica das águas da Bacia}

A bacia de estudo (formada pelos rios dos Macacos, Rainha e Cabeça) (Figura 12) possui trechos bem distintos: $O$ trecho superior (alto curso) apresenta forte declividade e vegetação mais densa, o trecho mediano demonstra o começo de alterações da qualidade da água, em evidência na bacia do rio Rainha (rio mais impactado dos três). O trecho final (baixo curso) é densamente urbanizado e plano, o que explica a ocorrência de inundações nessa região. 


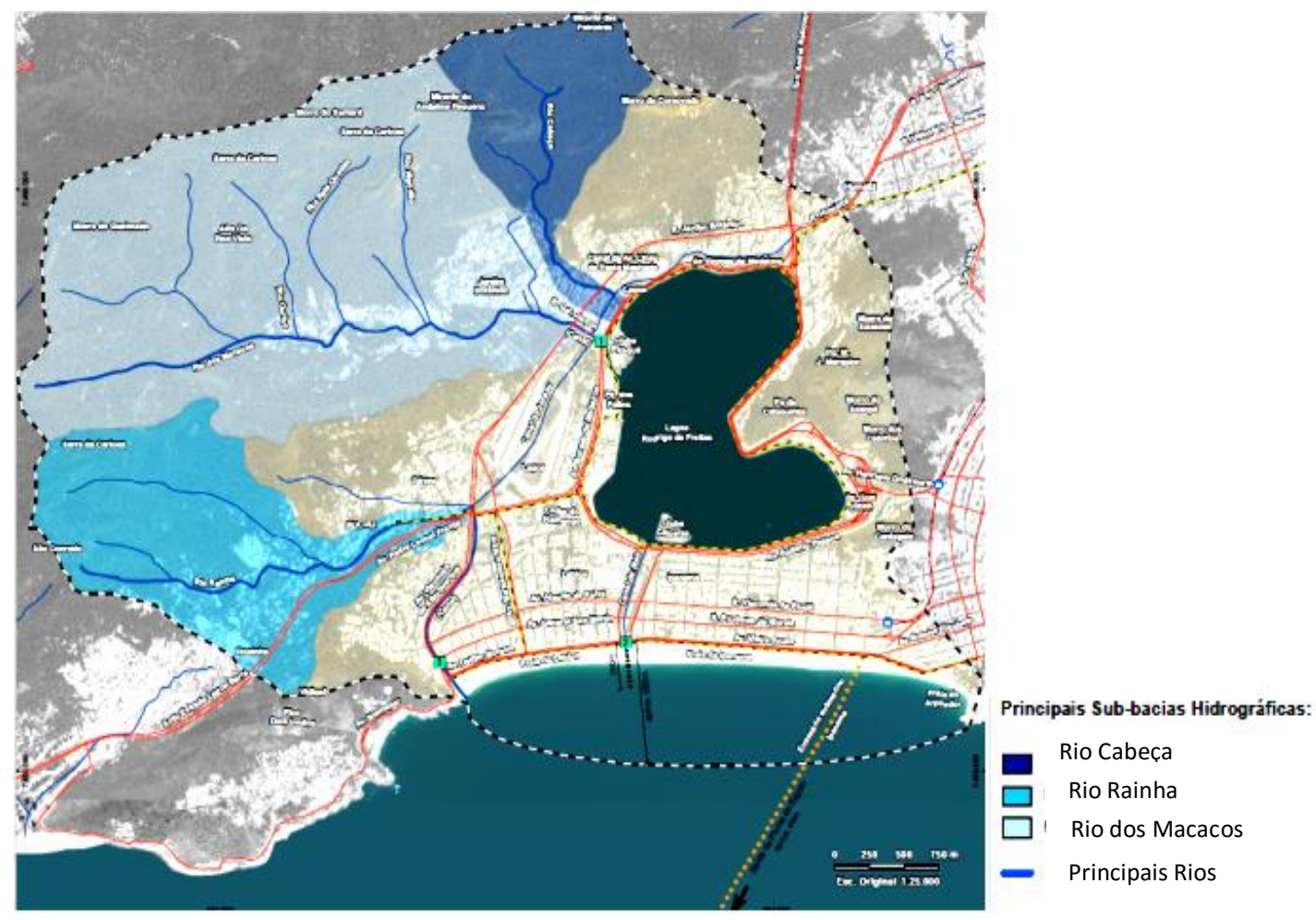

Figura 12 - Principais rios contribuintes à Bacia de estudo. Fonte. TECHNO-BIO (2012).

O deságue ou não dos principais rios da Bacia são controlados pela ação de duas comportas. O padrão normal de operação destas comportas é descrito a seguir de acordo com a Fundação Rio- Águas (2010) em seu Plano de Contingência e Monitoramento:

- Uma das comportas está localizada no final do canal da Avenida Visconde de Albuquerque, junto à praia do Leblon. Em dias de chuva, quando a comporta é aberta, esse canal promove o deságue do Rio Rainha no mar. $\mathrm{Na}$ ausência de chuvas a comporta serve como barreira ao deságue, sendo a água do canal direcionada à elevatória da Visconde de Albuquerque que recalca para o sistema CEDAE (emissário de Ipanema).

- A outra comporta está situada no Canal da Rua General Garzón (este canal é local de coleta das amostras do presente trabalho) e tem como objetivo evitar o deságue dos Rios Cabeça e Macacos na Lagoa Rodrigo de Freitas em tempo seco. Sua abertura ocorre em ocasiões de chuva, ocorrendo 
prováveis redirecionamentos do Rio Rainha do Canal da Visconde de Albuquerque para o Canal da Rua General Garzón.

Segundo a CEDAE (2014), entre as intervenções realizadas no entorno da Lagoa estão a implantação de galeria de cintura, elevatórias e recalques, direcionando as águas servidas provenientes das galerias de águas pluviais às elevatórias de esgotos em dias que não há ocorrência de chuvas intensas. Em relação ao complexo sistema de elevatórias, o destino final ocorre no emissário de Ipanema, atuando em série, com as linhas de recalque de uma elevatória lançando os esgotos em outra, até o lançamento no emissário terrestre (situado nas Avs. Delfim Moreira e Vieira Souto), que transporta os esgotos até a caixa de confluência do emissário submarino de Ipanema (ESEI).

Entre as ruas ocupadas pela rede de escoamento pluvial, a Rua General Garzón segundo LUCAS e CUNHA (2007), não possui um sistema complexo de escoamento, apenas valas no meio fio que escoam direto para dentro do canal.

Em tempo de altas precipitações, o fluxo dos rios Cabeça e Macacos extravasa a comporta da Rua Gal. Garzón, ou a comporta é aberta, alcançando a LRF. Dependendo da vazão do Rio Rainha, este é redirecionado através do Canal do Jockey para o Canal da Gal. Garzón, encontrando-se com os rios Cabeça e Macacos. Esta junção e consequente deságue na Lagoa em tempo de altas precipitações contribui para eventos de poluição. Para Andrade (1973), a comporta do Canal da Rua General Garzón seria uma permanente fonte de poluição, devido às águas dos rios que ali desembocam altamente contaminados pelos despejos que sofrem.

Em chuvas extremas, a LRF tem seu nível elevado consideravelmente devido ao assoreamento de sua embocadura, sendo que os locais de menor batimetria na Lagoa situam-se em áreas próximas ao deságue dos rios dos Macacos e Cabeça, além da área próxima ao Canal do Jardim de Alah por serem locais de deposição de sedimentos (TECHNO-BIO, 2012).

Percebe-se que a Lagoa Rodrigo de Freitas recebe a drenagem da sua área de entorno, funcionando como bacia de acumulação nas precipitações mais intensas. A ausência de cobertura vegetal na parte mais plana e urbanizada da 
bacia aliada à grande área pavimentada (impermeabilizada) acelera o processo de cheias durante as altas precipitações, já que a área disponível para infiltração é mínima devido à impermeabilização do solo por asfaltamento.

\subsubsection{Aspectos das sub-bacias}

Os principais rios contribuintes à Bacia da LRF que formam sub-bacias de mesmo nome tiveram seus percursos alterados ao longo dos anos, principalmente em sua parte baixa (parte mais urbanizada). Esses percursos foram alterados a partir de desvios e canalizações.

\subsubsection{Sub-bacia do Rio Cabeça}

A Sub-bacia do rio Cabeça drena as encostas situadas entre os morros Corcovado e Sumaré, e os bairros Alto da Boa Vista e Jardim Botânico, apresentando uma expressiva cobertura florestal contínua e pouco fragmentada. $\mathrm{O}$ ponto mais alto desta bacia é o morro do Corcovado, com 710m (TECHNO-BIO, 2012).

Sua área de drenagem é de $1,9 \mathrm{Km}^{2}$ (menor área de drenagem da Bacia). Deságua no Canal da Av. Lineu de Paula Machado, desembocando no Rio dos Macacos, no trecho da Rua General Garzón. Quando há ocorrência de alta pluviosidade podem ocorrer cheias.

\subsubsection{Sub-bacia do Rio Rainha}

Nasce na encosta sul da Serra da Carioca com uma área de drenagem de 4,3 $\mathrm{Km}^{2}$. O rio drena o bairro da Gávea, contando com a contribuição de pelo menos 4 nascentes identificadas, situadas no Alto Gávea. Os três braços drenam para o Canal Visconde de Albuquerque, a partir do leito canalizado no portão de entrada da Pontifícia Universidade Católica do Rio de Janeiro (PUC-Rio), e um quarto braço, com canalização superior em quase toda sua extensão, com trechos 
descobertos no pátio do Museu do Planetário sendo drenado no final do seu percurso para o Canal Visconde de Albuquerque.

Em tempos de chuva intensa, ocorre deságue no extremo oeste da Praia do Leblon, tendo sua descarga despejada diretamente no mar. Em períodos de tempo seco, a comporta fica fechada, sendo o volume d'água em parte bombeado para o emissário submarino de Ipanema (ESEI) e em parte acumulado para descargas em dias de chuva. Porém, pela manobra das diversas comportas, sob determinadas circunstâncias, pode ocorrer o desvio de sua drenagem para o Canal da Rua Gal. Garzón, interagindo nessas ocasiões com o Rio dos Macacos, por meio de um canal de drenagem que passa através do Jóquei Clube Brasileiro, permitindo escoamento nos dois sentidos, dependendo dos níveis d'água nos rios principais das duas bacias (MIGUEZ et al., 2012).

É considerada a sub-bacia em pior estado de conservação, percorrendo áreas ocupadas por condomínios residenciais ordenados e ocupações subnormais (percorre trechos da favela da Rocinha e Parque da Cidade), recebendo esgotos domésticos. Nos dias de alta pluviosidade, ocorre carreamento de partículas de solo, vegetação e lixos despejados irregularmente, provocando maior DBO do corpo hídrico durante estes eventos.

\subsubsection{Sub-bacia do Rio dos Macacos}

É a principal sub-bacia hidrográfica a desaguar na Lagoa Rodrigo de Freitas, apresentando a maior área de drenagem $\left(7,2 \mathrm{~km}^{2}\right)$, percorrendo os bairros Alto da Boa Vista e Jardim Botânico. Nasce nos contrafortes dos morros do Queimados e Sumaré, tendo como trechos finais a área interna do Jardim Botânico, seguindo para o canal da Rua General Garzón.

O ponto culminante é o Pico da Carioca, com $784 \mathrm{~m}$ de altitude, sendo bem drenada por numerosos tributários - riacho Pai Ricardo, córrego Xaxim, rio do Ouriço, riacho Sete Quedas e riacho Andaime (TECHNO-BIO, 2012). Alguns autores citam o lançamento de efluentes domésticos no rio desde seus afluentes (como o Rio Algodão). 
A encosta da serra ocupa grande parte de seu território, tendo uma transição para áreas de baixada, o que aumenta a tendência de escoamentos de alta velocidade, provocando ao chegar às planícies, alagamentos e elevado carreamento de materiais erodidos em função dessa mudança brusca de declividade. Durante eventos de chuva intensa, ocorre transbordo e alagamentos na Rua Jardim Botânico, importante via de comunicação entre a Zona Sul e a Zona Oeste.

Segundo LUCAS e CUNHA (2007), nos pontos mais baixos, onde o gradiente do canal apresenta pouca variação, o escoamento superficial ainda é o principal responsável pela contribuição hídrica para o canal, pois estas áreas apresentam-se densamente ocupadas e modificadas pela atuação antrópica. Como consequência deste processo, ocorre a impermeabilização do solo, impossibilitando a infiltração da água.

A interação com o Rio Rainha (já citada), além da contribuição do Rio Cabeças (seu principal tributário) no canal da Rua Gal. Garzón, pode provocar altas concentrações de matéria orgânica no local e também à LRF (caso haja abertura da comporta ou transbordo). Este canal encontra-se em vários momentos assoreado às margens e próximo à foz da Lagoa, resultado do carreamento desses rios, sendo necessárias intervenções de dragagem em certas épocas do ano.

As figuras 13 e 14 apresentam respectivamente o perímetro da Bacia do Rio dos Macacos (vista superior), e o perfil longitudinal de confluência dos rios contribuintes ao Canal da Rua Gal Garzón até o ponto anterior à comporta. 


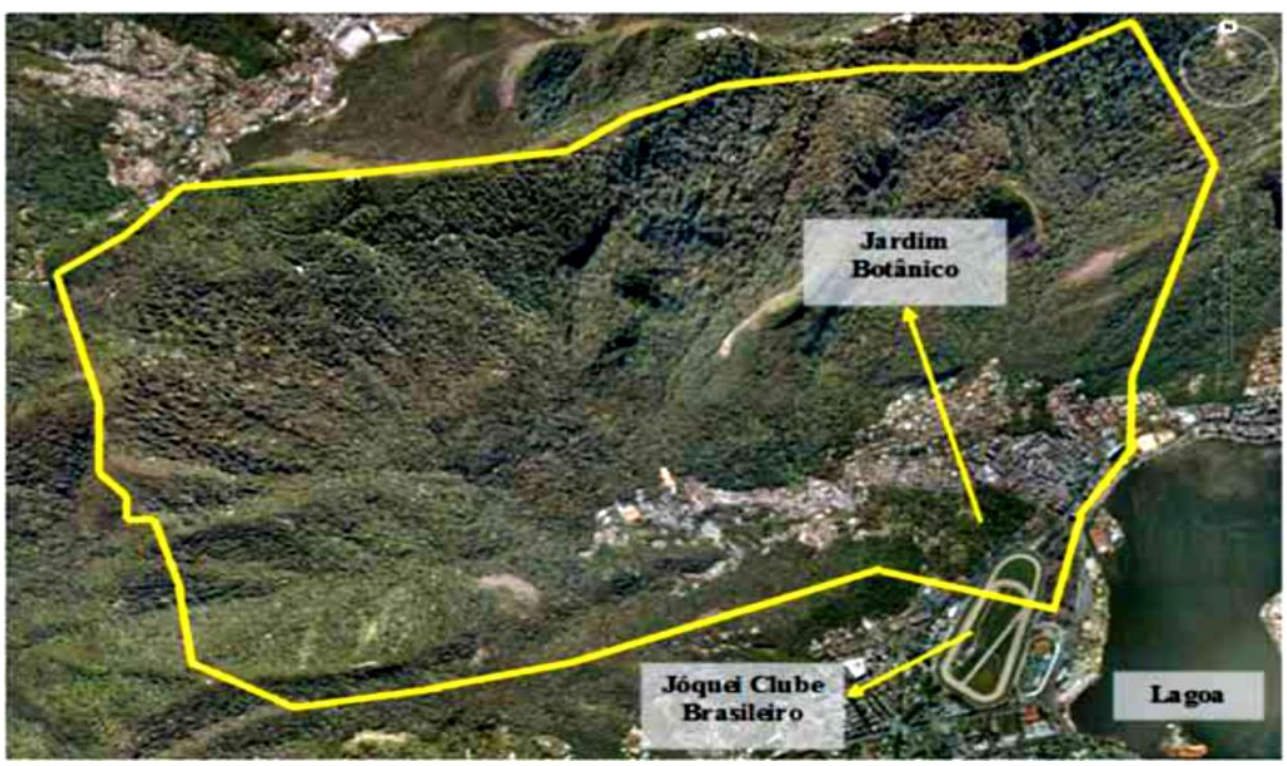

Figura 13 - Foto de satélite da bacia do Rio dos Macacos, com a Lagoa Rodrigo de Freitas como limite de jusante. Destaques para o Rio dos Macacos, em trecho dentro do Jardim Botânico (à esquerda), e para o Canal do Jóquei. Fonte: MIGUEZ et al., (2012).

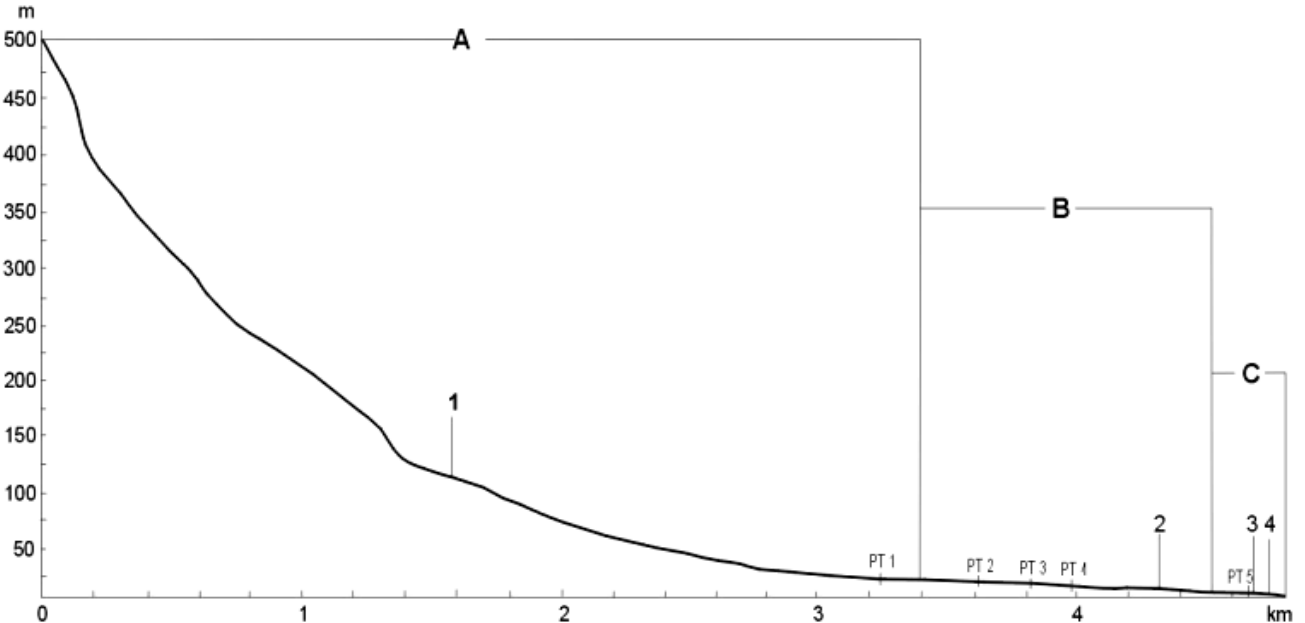

Figura 14 - Perfil longitudinal do Rio dos Macacos identificando a confluência com: (1) Riacho do Pai Ricardo, (2) Rio Algodão, (3) Rio Cabeça e (4) Rio Rainha. Fonte. LUCAS e CUNHA (2007). 


\subsubsection{Cenário atual da Lagoa Rodrigo de Freitas}

A qualidade física e química da água da LRF é o resultado das trocas que esta estabelece com o mar através do canal do Jardim de Alah, além das contribuições que recebe de águas fluviais e pluviais de sua sub-bacia, principalmente durante eventos de alta precipitação.

De acordo com MACHADO (2009), os problemas de escoamento na área da Bacia são recorrentes do aterramento de grandes extensões de suas margens, excessiva impermeabilização do terreno do seu entorno com intensa urbanização, que em tempos de precipitação intensa gera insuficiência da capacidade de vazão das galerias pluviais urbanas devido aos estrangulamentos e obstruções no Canal da Rua Gal. Garzón (que drena os rios Cabeça e Macacos) e no Canal da Av. Visconde de Albuquerque (que recebe o rio Rainha).

Os canais da bacia de drenagem e do Jardim de Alah contribuem com maior concentração de nutrientes, como por exemplo, o Fósforo. Estudos de DOMINGOS et al. (2012), demonstraram uma distribuição espacial de um padrão indicativo de lançamentos domésticos a partir do canal das Tábuas (Figura 15). A influência dos dois canais é marcante no padrão espacial verificado neste ambiente, elevando também os teores de DBO na Lagoa. Quando há enriquecimento, sobretudo de fósforo, há uma diminuição na produção da quantidade de oxigênio. Esse processo se agrava no período noturno, onde as microalgas param de realizar fotossíntese e passam só a consumir oxigênio, reduzindo ainda mais a concentração de OD na água, podendo causar mortandade de peixes. 


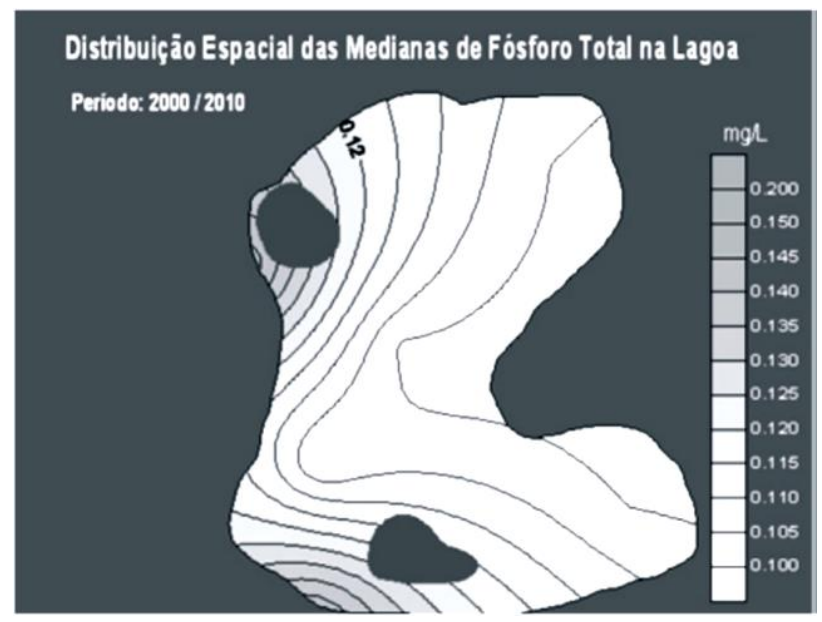

Figura 15 - Isolinhas das medianas de Fósforo Total (mg.L-1) do período de 2000 a 2010. Fonte. (DOMINGOS, P. et al., 2012).

Além de ser uma área totalmente urbanizada, sofrendo com o escoamento superficial urbano (run-off), segundo TECHNO-BIO (2012) em seus estudos de caracterização, a LRF também recebe um grande volume de esgoto despejado como importante fonte de poluição. Embora este não seja o único e principal fator causador da má qualidade da Lagoa, o lançamento de esgotos doméstico nos corpos hídricos da sua bacia ao longo do tempo contribui para as alterações do seu ecossistema. São notórios os lançamentos indevidos de esgotos nos cursos das sub- bacias e na própria LRF, sendo frequentemente noticiados pela mídia. Esses lançamentos podem ocorrer através de ligações clandestinas efetuadas no sistema de águas pluviais ou pelo extravasamento do próprio sistema de esgotamento sanitário durante as altas precipitações.

Como exemplo destes lançamentos, pode-se ver o que aparece próximo à área do Jockey Clube, através do Canal da Rua General Garzón, onde em determinadas ocasiões, observa-se o aparecimento de esgoto in natura nesse canal. As sub-bacias hidrográficas contribuintes à Lagoa também criam um maior quadro de poluição, pois recebem indevidamente lançamentos clandestinos de esgotos domésticos ao longo de seus percursos (devido à proliferação de moradias irregulares), quer por escoamento sobre o solo, por infiltração ou por extravasamento das galerias de águas pluviais, lança-os à Lagoa principalmente durante altas precipitações. Como agravante este canal apresenta contínua condição de confinamento, onde a água passa a apresentar movimento lêntico a 
quase estático, sendo a sua dinâmica condicionada principalmente aos eventos de abertura de comporta para a LRF.

Ainda hoje, apesar dos avanços registrados nos últimos anos sobre a qualidade das águas da LRF, observa-se um grande prejuízo no comportamento hidráulico da lagoa e no seu conjunto ambiental, repercutindo, dentre outros problemas, em eventos de mortandades de peixes, caracterizando um estágio de degradação (TECHNO-BIO, 2012). Já na década de 70, trabalhos investigativos eram realizados a respeito dessa mortalidade, onde Andrade (1973) realizou uma série de experimentos na Lagoa visando a medir a cinética de reação do consumo de oxigênio para uma melhor compreensão deste ambiente.

Essas ocorrências acontecem por interação desde fatores como aportes de esgotos domésticos sem tratamento devido ao barramento ineficiente das águas no Canal da Rua Gal. Garzón, ao fechamento da barra da LRF no Canal do Jardim de Alah ocasionado pelo carreamento de areia das praias de Ipanema e Leblon, ocorrência de altas temperaturas e longos períodos de insolação e pela entrada de frentes frias com a ocorrência de ventos e chuvas capazes de revolver o estoque de matéria orgânica acumulada no fundo da LRF ao longo de séculos (MACHADO, 2009) - sendo que os três últimos fatores citados são causados por processos naturais.

Essa matéria orgânica de fundo, também chamada "lama" ou "lodo", é constituída de material orgânico de origem vegetal, bem como o proveniente desses esgotos clandestinos em decomposição e da descarga fluvial que desembocam em suas águas. Esse material se acumula no fundo devido ao efeito da floculação e da gravidade. A degradação da matéria orgânica, em condições de anoxia, pelas bactérias sulfatoredutoras gera o gás sulfídrico $\left(\mathrm{H}_{2} \mathrm{~S}\right)$, presente nos sedimentos lamosos. O gás estocado que escapa para coluna a d'água (sob ação de ressuspensão dos sedimentos) provoca o odor fétido sulfuroso e a desoxigenação das águas superficiais (devido à oxidação química), dificultando a respiração dos peixes e provocando sua morte (LOUREIRO, 2006). 
DE PAULA (2009), elaborou um modelamento computacional mostrando a influência da descarga fluvial advinda do canal da Rua Gal. Garzón sobre a circulação na LRF. O autor relatou velocidades em torno de $0,055 \mathrm{~m} / \mathrm{s}$ no início do canal à 0,025 próximo à comporta, reduzindo em sentido à Ilha Piraquê para até $0,010 \mathrm{~m} / \mathrm{s}$ em alguns pontos. Foi observado que esta área apresenta velocidades com pequenas variações e fracas correntes de circulação. Ao considerar a influência do vento na circulação da Lagoa somado a descarga fluvial, encontrou-se velocidades inferiores a $0,05 \mathrm{~m} / \mathrm{s}$ na Lagoa (próximo ao Canal Piraquê). Ao avaliar a taxa de renovação das águas da Lagoa após 28 dias (tempo de um ciclo completo da maré) considerando o canal da Rua Gal. Garzón, obteve-se resultados de maior taxa de renovação em locais mais próximos ao canal do Jardim de Alah, sendo que a porção mais distante encerrou a simulação com apenas 55\% de renovação, valor próximo a taxa de renovação fornecida pela entrada das águas oriundas do canal da Rua Gal. Garzón à Lagoa. Segundo o autor, esse resultado demonstra que as descargas fluviais influenciam razoavelmente na composição das águas da LRF numa faixa de 800 metros a partir da metade da margem leste da Ilha do Piraquê, demonstrando diluição menos acentuada, com plumas de água menos renovada. Estes resultados são relacionados à implantação de guias- corrente na LRF proposta pelo LNEC (Lab. Nacional de Engenharia Costeira de Portugal) a fim de aumentar a comunicação do Canal do Jardim de Alah com a LRF. Percebe-se que mesmo com um projeto para melhoria da qualidade das águas da Lagoa, não há melhoria satisfatória na faixa de mediação a jusante do canal da R. Gal. Garzón. 


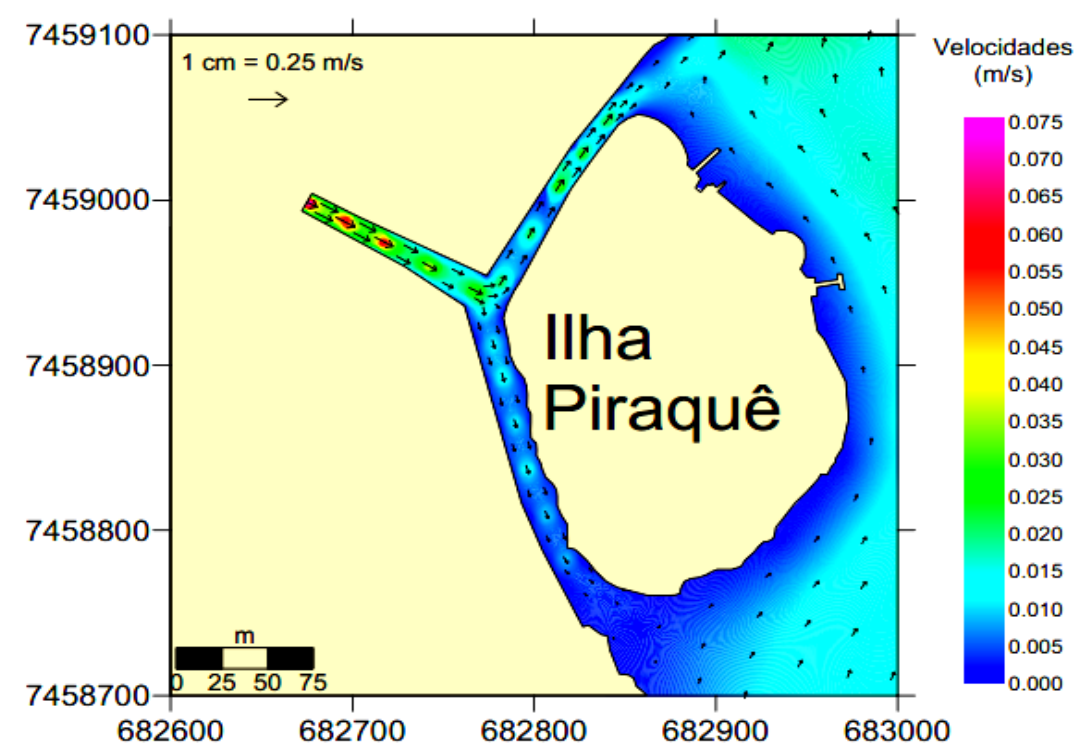

Figura 16 - Detalhe do campo de velocidade próximo à llha Piraquê, supondo o Canal do Jardim de Alah com guia - correntes já implantadas. Resultados obtidos pelo programa SisBaHIA. Fonte. DE PAULA (2009).

Então, podemos observar dois principais fatores contribuintes aos processos de poluição já descritos; o déficit na renovação das águas da LRF e ao mesmo tempo a incorporação de substâncias alóctones, principalmente devido ao seu papel de bacia sedimentar.

Estudos que favoreçam um melhor entendimento dos corpos hídricos, sejam canalizados ou não, proporcionam informações importantes sobre os processos atuantes nesse sistema fluvial. De acordo com LUCAS e CUNHA (2007), a adaptação de estudos e tecnologias podem ás vezes trazer alternativas para a manutenção de canais, como o Canal da Rua General Garzón, de modo que auxiliem na recuperação de suas características naturais.

\subsection{O Peróxido de Hidrogênio em Aplicações Ambientais}

\subsubsection{Processos oxidativos na remoção de poluentes}

A poluição causada pelo lançamento de poluentes no meio ambiente causa preocupação, principalmente pelos seus efeitos no ecossistema aquático e em consequência à saúde humana. Nos últimos anos vem-se observando uma maior 
atenção à poluição das águas, devido ao aumento da conscientização de sua importância e à rigidez das leis ambientais. Em decorrência destes fatos, tem-se observado avanços em pesquisa e desenvolvimento em busca de novas tecnologias para o tratamento de efluentes e descontaminação ambiental, sendo estes, objeto de grande interesse no âmbito social e científico.

As principais técnicas para tratamento de efluentes que contêm concentrações de poluentes envolvem processos químicos, físicos e biológicos. Nas ultimas décadas tem ocorrido um avanço no campo da pesquisa em busca de processos que tratem e/ou removam os poluentes presentes dos corpos hídricos e efluentes através de reagentes e materiais que não necessitem de remoção do meio após seu uso na remoção destes poluentes.

O uso dos oxidantes é uma alternativa interessante na remoção de determinados poluentes, sendo o cloro, oxigênio, ozônio e peróxido de hidrogênio os mais usados no tratamento de efluentes industriais para remover poluentes orgânicos e inorgânicos (TUNAY et al, 2010).

Entre os sistemas oxidantes, os POA's (processos oxidativos avançados) apresentam uma série de vantagens no tratamento de ambientes contaminados. Investigações a partir de processos oxidativos têm aumentado o interesse de utilização de tais processos (TEIXEIRA e JARDIM, 2004), seja combinados com outros processos / reagentes, ou pela aplicação direta de apenas um oxidante, como é o caso de investigação do presente trabalho.

Segundo KAVANAUGH et al. (2003), os POA's envolvem dois estágios de oxidação:

(1) A formação de oxidantes fortes (exemplo- radicais hidroxila); e

(2) A reação desses oxidantes com contaminantes orgânicos em água.

Dentre as técnicas de oxidação avançada destacam-se a utilização de ozônio, peróxido de hidrogênio, combinação destes (O3/H2O2 ou O3/H2O2/UV) (MATTOS et al., 2003), a reação de $\mathrm{H}_{2} \mathrm{O}_{2}$ com sais ferrosos (conhecido como reagente de Fenton - decomposição do peróxido catalisada por $\mathrm{Fe}^{2+}$ ) e a decomposição de $\mathrm{H}_{2} \mathrm{O}_{2}$ fotoassistida com radiação $\mathrm{UV}$, sendo todos possíveis 
fontes de radicais hidroxila para promover a degradação de diferentes compostos orgânicos.

$\mathrm{O}$ potencial de oxidação do radical ${ }^{\circ} \mathrm{OH}\left(\mathrm{E}_{\mathrm{h}}{ }^{\mathrm{T}}=2,80 \mathrm{~V}\right)$ é maior do que o dos outros oxidantes comumente usados (cloro, hipoclorito, ozônio), e apenas o flúor apresenta maior capacidade de oxidação $\left(\mathrm{E}_{\mathrm{h}}{ }^{\mathrm{o}}=3,03 \mathrm{~V}\right)$ (Tabela 4) (MARCELINO et al., 2013). A oxidação dos poluentes depende da estrutura do composto em questão. Podem ocorrer diferentes reações envolvendo o radical $\mathrm{OH}$, tais como abstração do átomo de hidrogênio, adição eletrofílica nas ligações insaturadas e em anéis aromáticos, transferência eletrônica e reação via radicalradical. $\mathrm{O} \mathrm{H}_{2} \mathrm{O}_{2}$ em solução pode se decompor em espécies radicalares, ou de acordo com o seu potencial de oxidação $\left(\mathrm{E}_{\mathrm{h}}{ }^{\mathrm{o}}=+1,77\right)$; também pode reagir diretamente com as substâncias químicas presentes no efluente, oxidando-as (NOGUEIRA, 2013). A formação destes complexos é rápida e equilíbrios são atingidos dentro de pouco tempo após a combinação de reagentes e/ou outros processos oxidativos e de soluções de $\mathrm{H}_{2} \mathrm{O}_{2}$. (DE LAAT e GALLARD, 1999).

Esses agentes oxidantes são moléculas relativamente instáveis que se decompõe na reação, formando-se em constituintes químicos diferentes. Um exemplo é o $\mathrm{H}_{2} \mathrm{O}_{2}$, onde dois moles produzem três moles por produtos $\left(2 \mathrm{H}_{2} \mathrm{O}_{2} \rightarrow\right.$ $2 \mathrm{H}_{2} \mathrm{O}+\mathrm{O}_{2}$ ) (LIPPINCOTT e WILKINS, 2001).

Tabela 3 - Potencial de oxidação de alguns oxidantes em água. Adaptado de MARCELINO et al.(2013); NOGUEIRA (2013).

\begin{tabular}{|c|c|}
\hline Oxidante & $\begin{array}{c}\text { Potencial de oxidação padrão } \\
(\mathrm{V})\end{array}$ \\
\hline Flúor $(\mathrm{F})$ & 3,03 \\
\hline Radical hidroxila $(\cdot \mathrm{OH})$ & 2,80 \\
\hline Peróxido de hidrogênio $\left(\mathrm{H}_{2} \mathrm{O}_{2}\right)$ & 1,77 \\
\hline
\end{tabular}


No presente estudo optou-se por utilizar o peróxido de hidrogênio devido às suas características ambientalmente amigáveis, favorável para utilização em águas superficiais de corpos hídricos, sendo, portanto, de interesse utilizar um processo que não necessite de outros reagentes / processos complementares, um tratamento que não forme subprodutos indesejáveis ao corpo hídrico e que seja economicamente viável.

\subsubsection{Características do peróxido de hidrogênio}

A primeira produção comercial de $\mathrm{H}_{2} \mathrm{O}_{2}$ data de 1800 , e sua produção mundial aumenta a cada ano. Seja na sua forma isolada ou combinada (mais utilizada), o peróxido vem sendo utilizado em diversas aplicações, principalmente no controle da poluição, nos processos de branqueamento na indústria têxtil, de papel e celulose, entre outros. Em adição à aceleração da decomposição de contaminantes, o peróxido tem sua reatividade aumentada na presença de metais de transição (como o cobre, ferro ou manganês) devido à formação de radicais livres intermediários (EPA, 2007) e também com a alcalinidade, incremento da temperatura, etc., (MATTOS et al., 2003).

Uma das vantagens do uso do peróxido é que uma vez que não há adição de outros compostos químicos além dele, os efluentes tratados podem ser realimentados em diferentes pontos de demanda de água nas instalações industriais sem restrições adicionais, desde que atendam aos objetivos de qualidade necessários (SUBTIL et al., 2009).

$\mathrm{O} \mathrm{H}_{2} \mathrm{O}_{2}$ pode participar de reações como agente oxidante ou redutor, dependendo do composto com o qual reage. As reações nas quais ele atua como agente oxidante são as mais importantes para seu uso industrial, pois ele oxida um grande número de compostos orgânicos e inorgânicos (ARELLANO, 2012). Apesar da reação do peróxido com poluentes orgânicos em água, a mineralização final de compostos orgânicos recalcitrantes e/ou remoção de tóxicos segundo TUNAY et al. (2010), não pode ser alcançada com eficiência por mera oxidação pelo peróxido na forma isolada. 
Essa possibilidade de mineralização dos poluentes orgânicos para produtos menos prejudiciais à saúde humana e ao ambiente aquático, caracterizam o peróxido de hidrogênio como um reagente ambientalmente amigável (TUNAY et al, 2010). A forma genérica de formação destes produtos através da ação do peróxido de hidrogênio é apresentada a seguir.

\section{$\mathrm{DBO} / \mathrm{DQO}+\mathrm{H2O2} \rightarrow$ espécies parcialmente oxidadas $\rightarrow \mathrm{CO} 2+\mathrm{H2O}+$ sais inorgânicos

Apesar do processo de oxidação avançada ser um método ambientalmente limpo para os poluentes orgânicos presentes em água, principalmente, devido à formação de $\mathrm{CO}_{2}$ e $\mathrm{H}_{2} \mathrm{O}$ (produtos do processo) (EL-SOUSY et al., 2007), devese atentar à formação do $\mathrm{CO}_{2}$ no processo de oxidação, principalmente tratando-se de uma área de estudo como desta investigação, a qual apresenta uma ampla diversidade de espécies aquáticas. Segundo SOUZA et al. (2012), as formas naturais de entrada do carbono nos corpos hídricos principalmente através de entradas fluviais apresentarão concentrações normalmente dependentes do tipo de vegetação, solo e litologia da bacia de drenagem. Geralmente o carbono inorgânico tende a ser um componente menor neste aporte, por predominarem processos de intemperismo químico e dissolução em relação à erosão e transporte.

Ao produzir $\mathrm{CO}_{2}$ dentro do corpo hídrico através de processos de oxidação, deve-se observar o $\mathrm{pH}$ do meio, já que a especiação química do $\mathrm{CO}_{2}$ na água e as concentrações dos íons produzidos por sua dissociação dependem, principalmente, da alteração do pH causada no sistema. Para LONGHINI (2010), as consequências dependem dos fatores que atuam para esta variação, onde processos que aumentem as concentrações de $\mathrm{CO}_{2}$ devem causar diminuição do pH da água.

$$
\mathrm{CO}_{2}+\mathrm{H}_{2} \mathrm{O} \rightarrow \mathrm{H}^{+}+\mathrm{HCO}_{3}^{-}
$$

A faixa de $\mathrm{pH}$ de acordo com o preconizado pela Resolução CONAMA 357/05 para águas solobras classe II, o qual se enquadra as águas da Lagoa Rodrigo de Freitas está entre 6,5 - 8,5. Estudos realizados na Lagoa como o de 
AMBIENTAL (2012), relata valores de pH entre outubro e janeiro (2011) variando de 7,10 a 8,20. DIAS (2010), durante evento de fortes ventos e chuva moderada no ponto central da Lagoa (próximo ao Clube Naval) obteve uma média de pH 7,5. WEELRET et al. (2012) relatou valores de pH com média de 8,5 e menores valores em ponto de amostragem próximo ao Jockey, na faixa de 7,6 e 7,8 .

O peróxido de hidrogênio também é usado para complementar o oxigênio dissolvido em sistemas de tratamento biológico para fornecer uma fonte imediata de OD (JOSEPH et al., 2011). Esse complemento de OD funcionará como fonte de oxigênio para a decomposição aeróbia da matéria orgânica.

A conversão de peróxido a OD em meio aquoso nestes casos prossegue de acordo com a seguinte reação de decomposição:

$$
2 \mathrm{H}_{2} \mathrm{O}_{2} \rightarrow 2 \mathrm{H}_{2} \mathrm{O}+\mathrm{O}_{2}
$$

A reação acima mostra que dois moles de peróxido irão produzir um mol de OD. Portanto, a quantidade de $\mathrm{H}_{2} \mathrm{O}_{2}$ necessário para oxigenar a água residual é relativamente pequena (JOSEPH et al., 2011).

Segundo a literatura, a decomposição do peróxido de hidrogênio $\left(2 \mathrm{H}_{2} \mathrm{O}_{2}\right.$ $\rightarrow \mathrm{H}_{2} \mathrm{O}+\mathrm{O}_{2}$ ) ocorre em função do $\mathrm{pH}$, sendo sua decomposição alcançada a uma maior taxa em pH alcalino. ARELLANO (2012) cita estudos de GALBACS E CZÁNI (1983), os quais obtiveram resultados que revelaram que o $\mathrm{H}_{2} \mathrm{O}_{2}$ se decompõe mais rapidamente em meio alcalino alcançando uma taxa máxima de decomposição no intervalo de pH 11 - 12.

De acordo com ARELLANO (2012), muitos esforços vêm sendo realizados objetivando esclarecer a auto decomposição do $\mathrm{H}_{2} \mathrm{O}_{2}$; porém, ainda não há conclusões satisfatórias devido às contradições no que concerne o caráter ácido e básico da decomposição, a sua dependência do $\mathrm{pH}$, sua cinética, presença de impurezas com efeito catalítico e mecanismo de reação. 


\subsubsection{Peróxido de hidrogênio em águas superficiais}

O peróxido de hidrogênio é produzido naturalmente em superfície aquática por processos fotoquímicos ocorrendo absorção de luz, matéria orgânica e oxigênio molecular. Mais precisamente, a produção natural ocorre quando o carbono orgânico dissolvido (COD) de substâncias húmicas é excitado por luz ultravioleta em água doce e ambientes marinhos (SCHMIDT et al., 2006). Segundo os autores, a concentração do $\mathrm{H}_{2} \mathrm{O}_{2}$ ocorre naturalmente em uma faixa de 0.001 a $0.0109 \mathrm{mg} . \mathrm{L}^{-1}$, onde as mais altas concentrações ocorrem tipicamente em superfícies aquáticas que contém alto COD.

O peróxido têm tido sua utilidade estudada em relação ao aumento do oxigênio dissolvido em cursos d'água, especialmente em dias chuvosos no verão, devido à alta contagem bacteriana e menor solubilidade do OD presente na água neste período, o que favorece menores concentrações de OD no ambiente aquático (JOSEPH, 2011), podendo então ser utilizado a fim de evitar déficits críticos de oxigênio para os organismos aquáticos aeróbios. Segundo a Agência Ambiental de Londres (ENVIRONMENT AGENCY, 1998), quando o peróxido é adicionado com o objetivo de elevar a concentração de OD de um corpo hídrico, é relevante observar alguns critérios para maximizar os efeitos:

(1) Nos rios que apresentam concentrações de poluição orgânica extremamente elevada, tais como o recebimento de uma grande quantidade de efluentes de esgoto tratado, a adição de peróxido resultará em um aumento temporário de oxigênio, até o oxidante ser totalmente utilizado;

(2) A taxa de produção de oxigênio decorrente da adição de peróxido para o corpo d'água é relacionado à matéria orgânica presente na água. Se a matéria orgânica estiver em baixas concentrações no corpo hídrico, o $\mathrm{H}_{2} \mathrm{O}_{2}$ não irá ser consumido ou irá decompor a uma taxa muito lenta. As bactérias aeróbias passam a florescer com o aumento da concentração do oxigênio, o que possibilita a biodegradação dos compostos orgânicos presentes no corpo hídrico. 
(3) A adição de peróxido a montante pode ser suficiente para manter níveis de oxigênio ou até que a DBO do poluente tenha sido suficientemente diluída por afluentes de entrada ou através de chuvas.

Nesse estudo recomenda-se ainda para maior eficiência, uma aplicação ao longo de um período de tempo em vez de realizar aplicações em dose única, pois deve-se atentar ao percurso que o oxidante faz ao logo do curso do rio, podendo não alcançar em uma só dosagem toda a área necessária à ser tratada dependendo do volume, da velocidade e do comprimento do corpo hídrico ao qual o oxidante irá percorrer e reagir.

A seguir (Figura 17), fluxograma apresentado pela ENVIRONMENT AGENCY (1998) para tomada de decisões ao utilizar peróxido em águas, devendo-se observar o tipo de poluição e o fluxo do corpo hídrico.

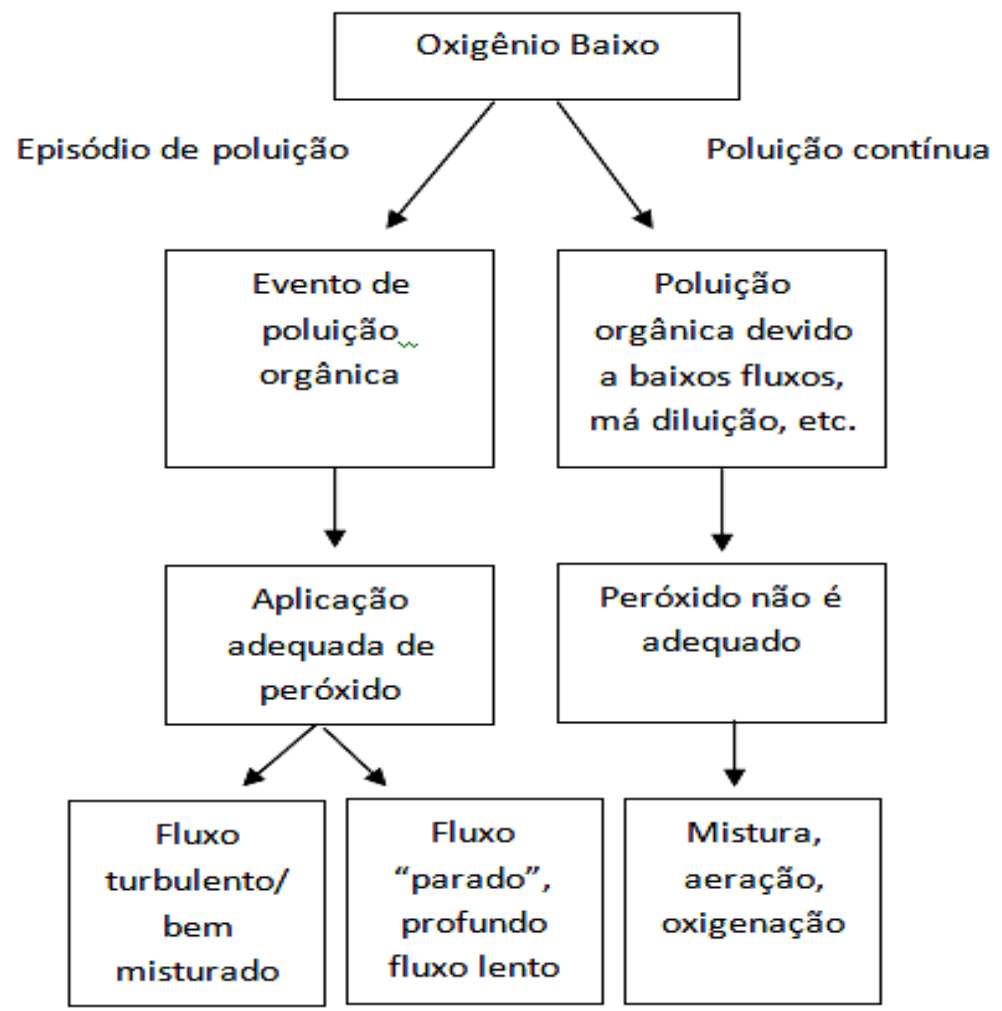

Figura 17 - Fluxograma de aplicação de peróxido de hidrogênio em corpos hídricos com baixa concentração de oxigênio dissolvido. 
Assume-se que a degradação do peróxido de hidrogênio em ambientes aquáticos aeróbios siga cinética de primeira ordem a baixas concentrações, apresentando meia-vida entre minutos e horas em águas residuárias municipais (> $10^{6}$ células $\left./ \mathrm{mL}\right)$, poucos segundos em lodos $\left(10^{8}-10^{10}\right.$ células $\left./ \mathrm{mL}\right)$, e de horas a dias em águas naturais $\left(<10^{3}\right.$ células/mL) (EPA, 2007).

Entre os fatores que se deve atentar durante o uso do peróxido em corpos d'água superficiais, está a ecotoxicidade para os organismos aquáticos, sendo estes organismos os que apresentam maior potencial de serem afetados pelo contato direto através de elevadas concentrações e pelo tempo de exposição ao oxidante.

\subsubsection{Ecotoxicidade de $\mathrm{H}_{2} \mathrm{O}_{2}$ em águas naturais}

Nos EUA, o peróxido de hidrogênio é registrado como um pesticida pela EPA desde 1977. É estabelecido que em concentrações superiores a $75 \mathrm{mg} / \mathrm{L}$ pode causar prejuízos, sendo de alta periculosidade à vida ou à saúde humana (JOSEPH et al., 2011). Porém, para as espécies aquáticas, este valor limite de concentração de toxicidade é variável em relação à espécie.

A toxicidade é um fator que deve ser levado em consideração durante a aplicação de um oxidante, já que há um aumento progressivo do risco de toxicidade de acordo com o tempo de exposição. Segundo a ENVIRONMENT AGENCY, (1998), altas concentrações de peróxido podem ter efeito determinante na comunidade invertebrada de um curso d'água, podendo também prejudicar indiretamente os peixes, já que pode ocorrer alteração na cadeia alimentar.

Em relação à aplicação da dosagem do $\mathrm{H}_{2} \mathrm{O}_{2}$, segundo LIPPINCOTT e WILKINS (2001), as concentrações a nível seguro vão tipicamente até a faixa de 20,0 mg/L, onde algumas espécies podem apresentar maior sensibilidade do que outras (como algas e crustáceos), podendo ser necessário uma menor dosagem para espécies particularmente mais vulneráveis. A literatura apresenta níveis de toxicidade para algumas espécies aquáticas, porém é importante ressaltar que essas concentrações avaliadas devem variar de acordo com a espécie e o ambiente. 
Segundo a ENVIRONMENT AGENCY (1998), as cianobactérias aparentemente estão entre o grupo de organismos aquáticos que apresenta maior vulnerabilidade aos efeitos do peróxido. Foi encontrado ser moderadamente a alta, a toxicidade para esses organismos com curto e longo tempo de exposição. Efeitos de concentração de 1,7 a 6,8; 1,6 a 3,0 e 0,25 a 1,0 mg/L foram reportados por várias espécies seguidas à exposição em laboratório por 24 a 48 horas, 5,8 dias e 32 dias respectivamente.

A Agência de Proteção Ambiental (EPA, 2007) avaliou peixes de três espécies para toxicidade aguda em água doce em solução de Proxitane (concentração de $15 \%$ de ácido paracético e $22 \%$ de peróxido de hidrogênio), onde a espécie mais sensível ao teste foi a truta, com $\mathrm{CL}=0,72 \mathrm{mg} / \mathrm{L}$. Para peixes de ambiente estuarino, a sensibilidade para os testes foi menor, porém, a Agência preconizou o valor de CL da truta de água doce para as futuras avaliações. Já para testes com apenas peróxido de hidrogênio, peixes da espécie Pimephales promelas, também de água doce, apresentaram $\mathrm{CL}_{50}$ de $96 \mathrm{~h}$, com concentração de 16,4 mg/L (PEROXIDOS DO BRASIL, 2014); (PROTECTION ENVIRONMENTAL, 2010). A EPA (2007) relata não ter sido observado dados significativos de bioacumulação de peróxido de hidrogênio em organismos aquáticos.

ZAGATTO (1995), avaliou diversos algicidas, dentre eles o peróxido de hidrogênio a fim de determinar a toxicidade de organismos não-alvo no reservatório de Guarapiranga (SP) cujos resultados apresentaram $\mathrm{CL}_{50}$ de $96 \mathrm{~h}$ com concentração de 5,10 e 0,22 mg. $\mathrm{L}^{-1}$ para as espécies de peixe Danio rerio e espécie de crustáceo Daphnia similis, respectivamente.

No Brasil, a CETESB (2005) fixa valores de toxicidade para $\mathrm{H}_{2} \mathrm{O}_{2}$ acima de $40 \mathrm{mg} / \mathrm{L}$ em organismos aquáticos, sendo este valor designado para espécies de água salina, cujo tempo de contato não é determinado.

Não foi possível obter na literatura dados de ecotoxicidade do peróxido de hidrogênio para as espécies de peixes com maior representatividade na Lagoa Rodrigo de Freitas (Brevoortia pectinata- nome popular: Savelha; Genidens genidens- nome popular: Bagre; Geophagus brasiliensis- nome popular: Acará; 
Jenynsia lineata- nome popular: Barrigudinho; Mugil Liza- nome popular: Tainha) (ANDREATA et al., 1997).

A recomendação da ENVIRONMENT AGENCY (1998) de Londres quanto à limitação de exposição da vida aquática ao peróxido de hidrogênio aplicado na água do rio é de que após a aplicação de uma dose de $\mathrm{H}_{2} \mathrm{O}_{2}$, a concentração média de $\mathrm{H}_{2} \mathrm{O}_{2}$ durante as primeiras 24 hs da aplicação não exceda 1 mg/L. Por exemplo: a aplicação de uma dose de $10 \mathrm{mg} / \mathrm{L}$, decaindo linearmente a $1 \mathrm{mg} / \mathrm{L}$ em $2 \mathrm{~h}$ e daí linearmente a zero $\mathrm{mg} / \mathrm{L}$ ao fim de $24 \mathrm{hs}$, resultaria em uma concentração média de $\mathrm{H}_{2} \mathrm{O}_{2}$ no período de 24 hs igual a $0,87 \mathrm{mg} / \mathrm{L}$.

O presente estudo considerará como condições limitantes as concentrações seguras de peróxido de acordo com a literatura citada, e valores de decaimento do oxidante de acordo com o recomendado pela ENVIRONMENT AGENCY (1998) devido à presença de organismos mais sensíveis à ação do peróxido na LRF (como algas e crustáceos).

\subsubsection{Experiências da aplicação de peróxido de hidrogênio em remediação ambiental}

Nos Estados Unidos, o peróxido de hidrogênio vem sendo usado com frequência para tratar o abastecimento de águas. Ele é utilizado para prevenir ou corrigir a formação de cor, sabores e odores indesejáveis, corrosão e degradação à poluição e degradação dos microrganismos (JOSEPH et al., 2011).

SILVA et al. (2014), relataram o caso do Rio Grande da Serra (SP), o qual ao longo de sua extensão recebe esgoto industrial e doméstico, tendo a jusante do braço do rio uma estação de tratamento de água (ETA), onde são constantes as aplicações alternadas de peróxido de hidrogênio e sulfato de cobre para o controle da biomassa algal, a fim de evitar a geração da altas concentrações de produtos da decomposição das algas e sua consequente comunicação de gosto e odor desagradáveis. Apesar do poder algicida do oxidante à água, a aplicação de sulfato de cobre na água como algicida é segundo os autores uma técnica ultrapassada, já 
que pode promover o acúmulo de cobre no sedimento, onde, conforme a condição ambiental, pode se tornar biodisponível.

No Rio Besos (Espanha) durante o verão, a temperatura da água aumentava para valores próximos a $30^{\circ} \mathrm{C}$, causando frequentemente condições anaeróbias e geração de sulfeto a partir do sulfato. O peróxido foi usado para tratar o rio (em 1995), oxidando o sulfeto através de dosagens contínuas nas seis maiores plantas de emissários de esgotos a níveis entre 10 e $40 \mathrm{mg}$. $\mathrm{L}^{-1}$. Os níveis de sulfeto foram mantidos abaixo de $2,0 \mathrm{mg}$. $\mathrm{L}^{-1}$ (durante o verão estavam a 17,0 mg. $\mathrm{L}^{-1}$ ), reduzindo com eficácia o odor de $\mathrm{H}_{2} \mathrm{~S}$ (ENVIRONMENT AGENCY, 1998).

Lagoas de chorume que foram descarregadas para uma vala de água de superfície, acabaram sendo encaminhadas para o Rio Tâmisa (Inglaterra), o que causou forte odor de $\mathrm{H}_{2} \mathrm{~S}$. Este foi então controlado em uma das lagoas usando-se peróxido por gotejamento ao longo de 20 metros. $\mathrm{O} \mathrm{H}_{2} \mathrm{O}_{2}$ foi distribuído por injeção a uma taxa aproximada de $100 \mathrm{~mL} / \mathrm{min}$. e circulação ao longo de 5 dias para oxidar o sulfeto mais rapidamente. A dosagem foi depois reduzida para 9,0 mg. $L^{-1}$, para manter as condições aeróbias. Após 10 semanas, observou-se valores de decaimento de DBO de 2.500 para $980 \mathrm{mg}$. L ${ }^{-1}$; TOC de 949 para $400 \mathrm{mg}$. L ${ }^{-1} \mathrm{e}$ sólidos suspensos de 165 para 43 mg. L ${ }^{-1}$ (ENVIRONMENT AGENCY, 1998).

Durante eventos de forte chuva, o sistema de coleta de esgoto combinado de Londres por não ter capacidade de receber os dois tipos de despejo nessas ocasiões, acabava transbordando e atingindo o curso do Rio Tâmisa. Isso tinha um grande efeito sobre a qualidade da água, baixando rapidamente os níveis de oxigênio, em especial nos trechos do rio onde o esgoto foi lançado, podendo provocar mortandade de peixes. Em agosto de 2004, tempestades torrenciais afetaram o centro de Londres, ocorrendo transbordo de esgoto para o Tâmisa, causando a morte de milhares de peixes em um único dia (COELHO, 2007). A partir deste evento criou-se um grupo em conjunto com a Agência Ambiental de Londres (Environment Agency) para solucionar o problema. Passou-se a intensificar a injeção de oxigênio no rio (esse processo já era utilizado desde a década de 80 por ação de barcos e pequenas embarcações). Segundo COELHO (2007), quando se constata a queda do OD da água, em poucas horas as 
embarcações são postas em ação para injetar no rio quantidades necessárias de peróxido de hidrogênio como fonte adicional de oxigenação. Segundo o autor, este fator contribui significativamente para que o Tâmisa continue a ser um dos rios urbanos mais limpos do mundo.

Apesar de trabalhos relacionados à aplicação do peróxido de hidrogênio em rios, ainda há pouca documentação e divulgação de estudos científicos, sendo encontrados trabalhos mais voltados à aplicabilidade, com enfoque em conteúdos técnicos.

A partir da revisão de literatura e dos objetivos apresentados no presente trabalho, apresenta-se a seguir a metodologia experimental utilizada para o presente estudo. 


\section{Materiais e Métodos}

Este capítulo descreve o procedimento experimental empregado no trabalho e a área geográfica de amostragem deste estudo.

A parte experimental apresentada a seguir foi dividida em duas etapas:

(1) - Experimentos de caracterização do corpo hídrico no local de amostragem;

(2) - Ensaios de dosagens de $\mathrm{H}_{2} \mathrm{O}_{2}$ medindo-se sua concentração residual e a formação de oxigênio dissolvido no decorrer do tempo reacional.

\subsection{Coleta e época das amostragens}

As amostras foram coletadas em frascos de polipropileno e preservadas conforme a norma ABNT NBR 9898/97 (Preservação e técnicas de amostragem de efluentes líquidos e corpos receptores) e a Guia Nacional de Coleta e Preservação de Amostras de Águas da Agência Nacional de Águas (ANA, 2012). As amostras foram coletadas ao término dos eventos de chuva (entre uma a duas horas após o término), sendo encaminhadas ao laboratório, onde permaneceram refrigeradas $\left(\mathrm{a}^{\circ} \mathrm{C}\right)$ até a realização dos experimentos.

As coletas ocorreram durante os meses de agosto a dezembro de 2014, e janeiro de 2015, em períodos de precipitação e de tempo seco.

Foram definidos três pontos de amostragem (de acordo com a ABNT NBR 9898/97). Os pontos estão situados no Canal da Rua General Garzón, localizado no bairro Jardim Botânico, cidade do Rio de Janeiro - RJ. A coleta ocorreu a uma distância de aproximadamente 115 metros do ponto 1 ao ponto 2 e de 65 metros do ponto 2 ao ponto 3 (Google Earth, 2014). Os pontos de coleta foram definidos levando-se em consideração os locais de deságue dos rios da sub - bacia hidrográfica da LRF ao Canal da Rua Gal. Garzón. 


\subsubsection{Posicionamento dos pontos de amostragem}

Para ilustrar a definição dos pontos, foi elaborado um mapa no programa Quantum Gis (Versão 6.4), a fim de permitir uma visualização espacial da área de amostragem (Figura 18).

Pontos de amostragem:

Ponto 1 - Ponto de entrada do Rio dos Macacos no canal da Rua General Garzón.

Ponto 2 - Ponto a jusante à contribuição do Rio Cabeças (localizado no canal da Av. Lineu de Paula Machado) ao Rio dos Macacos no canal da Rua General Garzón.

Ponto 3 - Localiza-se ao final da extensão do canal, próximo à comporta cuja abertura é controlada pela Prefeitura da cidade através da Fundação Rio - Águas, sendo este ponto responsável pelo deságue dos rios em estudo na Lagoa Rodrigo de Freitas em determinados episódios de chuva. Ocorre neste ponto contribuição ocasional do Rio Rainha através do Canal do Jockey. 


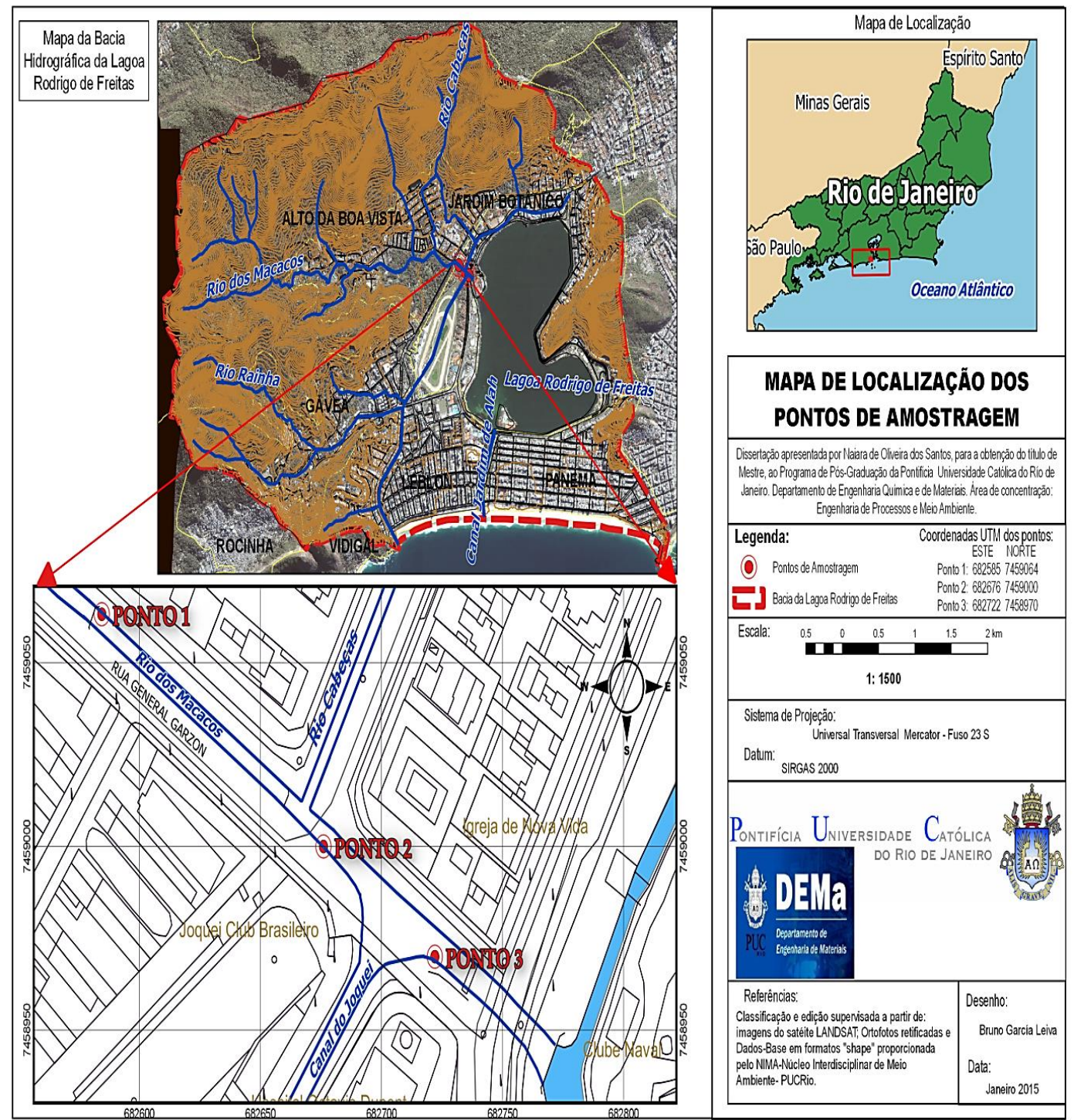

Figura 18 - Localização dos pontos de amostragem no Canal da Rua General Garzón.

Mapa elaborado no programa Quantum Gis (versão 6.4).

\subsection{Análises de caracterização da área de estudo}

Com o objetivo de obter informações complementares acerca da área de estudo, serão apresentados a seguir alguns parâmetros de qualidade da água acompanhados neste estudo.

As análises de COT e DBO foram realizadas na Universidade Federal do Rio de Janeiro (UFRJ), no Laboratório de Núcleo Integrado para Reuso de Águas e Efluentes do Estado do Rio de Janeiro (NIRAERJ - LabTare). As análises de 
fósforo total, SST e elementos-traço foram realizadas na Pontifícia Universidade Católica do Rio de Janeiro (PUC - Rio) no Laboratório de Águas (LabAguas).

\subsubsection{Determinação dos Sólidos Suspensos ou Não Filtráveis}

Para determinação das frações dos sólidos em suspensão, foi seguida a metodologia do Manual de Análises Físico-Químicas de Águas (LabAguas - PUC Rio) análoga ao método Standard Methods of Examination of Water e Wastewater $-2540 \mathrm{D}$ - Total Suspended Solids Dried at $103-105^{\circ} \mathrm{C}$.

\subsubsection{Procedimento Metodológico}

As amostras foram passadas em filtro membrana de fibra de vidro com diâmetro de poros de $0,45 \mu \mathrm{m}$. Este filtro foi previamente preparado, sendo umedecido com água destilada no conjunto de filtração a vácuo (Figura 19) e em seguida seco em estufa (Figura 20) por 1 hora entre 103 e $105^{\circ} \mathrm{C}$. Após secagem na estufa, o filtro foi armazenado em dessecador com sílica-gel e pesado em balança analítica $\left(\mathrm{P}_{0}\right)$.

Para determinação dos sólidos em suspensão totais (SST), foi filtrado a vácuo um volume de $50 \mathrm{~mL}$ da amostra. Já com o resíduo em suspensão, o filtro foi levado à estufa por uma hora entre 103 e $105^{\circ} \mathrm{C}$. Após, o resíduo seco obtido no filtro foi armazenado em um dessecador até pesagem em balança analítica (P1). 


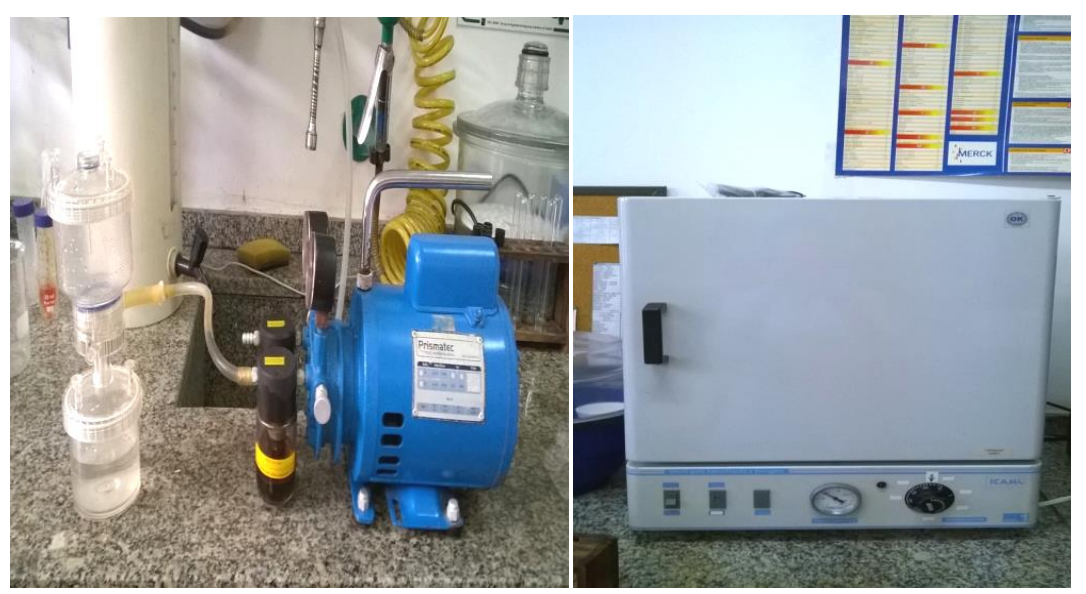

Figuras 19 - Filtro e bomba de sucção à vácuo. LabAguas (PUC- Rio). Figura 20 - Estufa de secagem das amostras. LabAguas (PUC- Rio).

A relação envolvida entre os pesos foram as seguintes:

$$
1000(\mathrm{E}-\mathrm{D}) / \mathrm{VA} / 1000=\mathrm{SST}(\mathrm{mg} / \mathrm{L})
$$

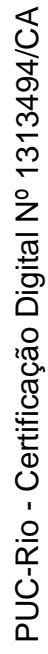

Onde:

$\mathrm{D}=$ peso do papel de filtro tratado $(\mathrm{g}) ; \mathrm{E}=$ peso do papel de filtro após filtração da amostra e secagem $(\mathrm{g}) ; \mathrm{F}$ = peso do papel de filtro após ignição (g); $\mathrm{VA}=$ volume da amostra $(\mathrm{mL})$.

A seguir, fluxograma do processo realizado para determinação dos sólidos em suspensão:

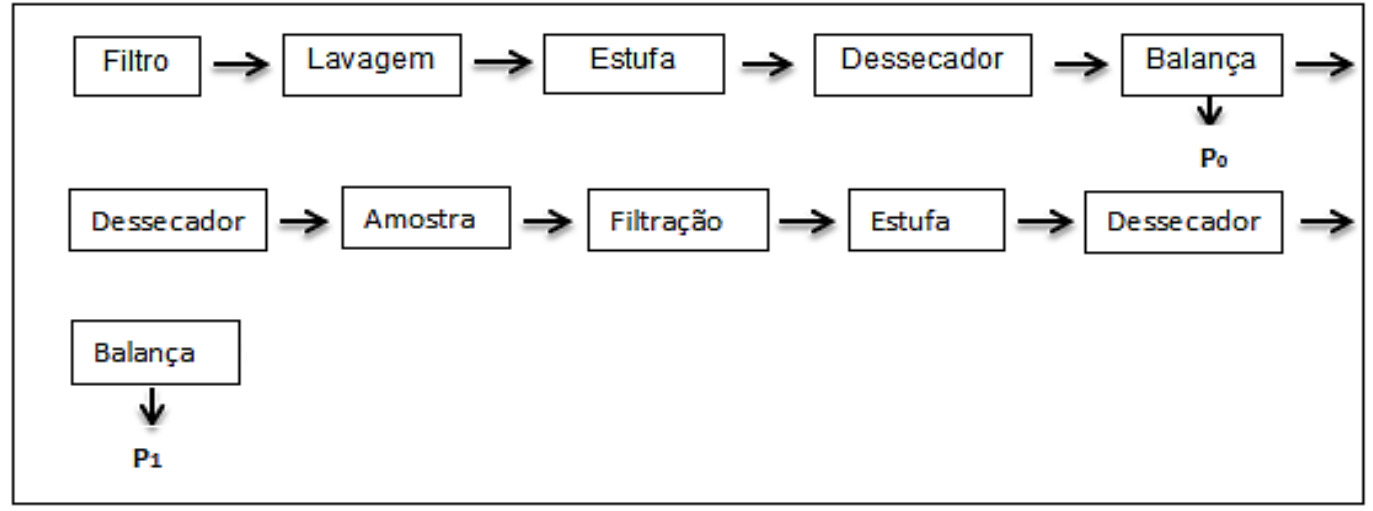

Figura 21 - Fluxograma do procedimento para determinação de sólidos em suspensão de acordo com Manual de Metodologias LabAguas (PUC- Rio) . 


\subsubsection{Demanda Bioquímica de Oxigênio $\left(\mathrm{DBO}_{5}\right)$}

As análises de DBO foram realizadas seguindo o método FEEMA (MF439-R1) em acordo com a descrição do Standard Methods for the Examination of Water and Wateswater.

O princípio do método corresponde à diferença entre as concentrações de oxigênio dissolvido no início e no fim do período de incubação da amostra, em condições específicas de ensaio. A incubação é padronizada em $20^{\circ} \mathrm{C}$ e o tempo de incubação em cinco dias. O oxigênio dissolvido é medido antes e depois da incubação e a $\mathrm{DBO}_{5}$ é calculada a partir da diferença de oxigênio dissolvido obtida, multiplicada ao fator de diluição (quando é necessário diluir a amostra). Presume-se que nestas condições cerca de $80 \%$ da matéria orgânica carbonada já esteja mineralizada. Uma oxidação total leva cerca de 20 dias ( DBO $\left._{\text {ultima }}\right)$. (DBO final)

\subsubsection{Procedimento Metodológico}

Para a incubação e leitura, as amostras foram acondicionadas em frascos padrão de DBO (300 mL) (todos em triplicata), com soluções previamente preparadas de: frascos do branco, frascos de controle, frascos de semente e frascos das amostras.

A água destilada utilizada neste procedimento foi previamente armazenada em incubadora em temperatura aproximada de $20^{\circ} \mathrm{C}$ e aerada com o objetivo de seguir as condições de temperatura de $20^{\circ} \mathrm{C}$ e OD de aproximadamente $8,9 \mathrm{mg} / \mathrm{L}$.

Antes da incubação de cinco dias, leu-se a concentração de oxigênio dissolvido dos frascos (OD inicial). Completado o período de incubação, determinou-se as concentrações residuais de oxigênio dissolvido das amostras e das provas em branco (Manual de Análises Físico-Químicas de Águas de Abastecimento e Residuárias, UFRJ) a partir de oxímetro marca YSI modelo 5100. A diferença obtida da concentração inicial e final do oxigênio dissolvido é utilizada para o cálculo da DBO considerando o fator de diluição. 
Equação utilizada para o cálculo da $\mathrm{DBO}_{5}$ :

$$
\operatorname{DBO5}\left(\mathrm{mg} \mathrm{O}_{2} / \mathrm{L}\right)=\left[\left(\mathrm{OD}_{\mathrm{i}}-\mathrm{OD}_{5}\right)-\left(\mathrm{ODS}_{\mathrm{i}}-\mathrm{ODS}_{5}\right) \mathrm{f}\right] \times \mathrm{VF} / \mathrm{VA}
$$

Onde:

OD $_{\mathbf{i}}(\mathbf{m g} / \mathbf{L})=$ oxigênio dissolvido da prova diluída imediatamente após a preparação;

OD $_{5}(\mathbf{m g} / \mathbf{L})=$ oxigênio dissolvido da amostra diluída após incubação durante 5 dias a $20^{\circ} \mathrm{C}$;

$\mathbf{O D S}_{\mathbf{i}}(\mathbf{m g} / \mathbf{L})=$ oxigênio dissolvido do controle da semente antes da incubação.

ODS $_{5}(\mathbf{m g} / \mathbf{L})=$ oxigênio dissolvido do controle da semente após incubação durante 5 dias a $20^{\circ} \mathrm{C}$;

$\mathbf{V F}=$ volume do frasco de $\mathrm{DBO}(\mathrm{mL})$;

VA= volume da amostra $(\mathrm{mL})$.

$\mathbf{f}=$ relação entre a semente na amostra diluída e a semente no controle.

\subsubsection{Determinação de Carbono Orgânico Total (COT)}

A análise de COT considera as parcelas biodegradável e não biodegradável da matéria orgânica, não sofrendo interferência de outros átomos que estejam ligados à estrutura orgânica, quantificando apenas o carbono presente na amostra. O método é baseado na quantificação do carbono total (CT) e do carbono inorgânico (CI). O carbono inorgânico é definido como a soma de carbonatos e bicarbonatos. A diferença entre esses valores quantificados fornece o valor do carbono orgânico total $(\mathrm{COT}=\mathrm{CT}-\mathrm{CI})$.

\subsubsection{Procedimento Metodológico}

A medida é realizada pela concentração de carbono orgânico oxidado a $\mathrm{CO}_{2}$ pelo método do persulfato UV. O teor de carbono orgânico total das amostras foi medido no Analisador de COT marca Thermo Scientific modelo Hiper Toc, cujas amostras foram preparadas em triplicata através de metodologia do Laboratório de Núcleo Integrado para Reuso de Águas e Efluentes do Estado do Rio de Janeiro (NIRAERJ- LabTare). 


\subsubsection{Determinação de Fósforo Total}

Para determinação de fósforo total, foi seguida a metodologia do Manual de Análises Físico-Químicas de Águas, onde o processo de digestão é análogo ao item 5 do método 4500-B do US Standard Methods e a determinação de fosfato é análogo aos métodos EPA 365.2+3, US Standard Methods 4500-P E. Através do processo de digestão, o fósforo total é transformado em fosfato, que é lido através do Kit de Fosfato Spectroquant Merck.

\subsubsection{Procedimento Metodológico}

Para a leitura das amostras, foi utilizado espectofotômetro Spectroquant Nova 80 (Merck) (Figura 22). O preparo e leitura das amostras foram realizados em duplicata.

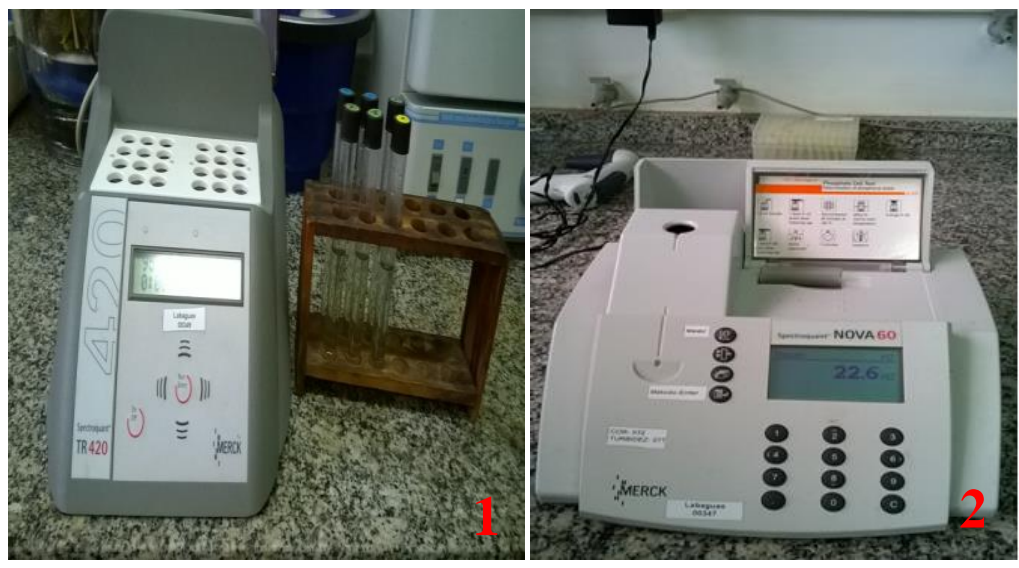

Figura 22 - (1) Aparelho digestor - Merck 420. (2) Aparelho espectofotômetro Spectroquant Nova 80 (Merck). 
A seguir, fluxograma para a determinação do Fósforo Total.

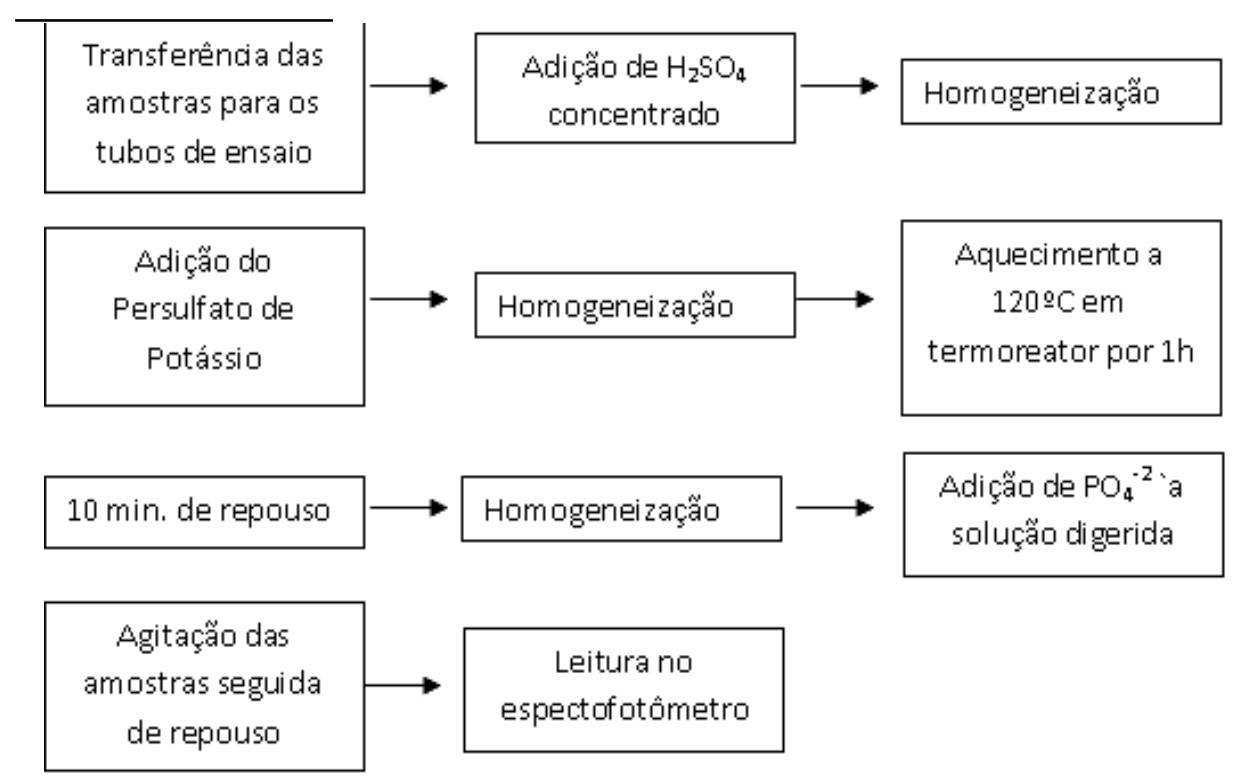

Figura 23 - Fluxograma do procedimento para determinação de Fósforo Total de acordo com Manual de Metodologias LabAguas (PUC- Rio).

\subsubsection{Determinação de Elementos- traço}

Após serem entregues ao laboratório, as amostras foram filtradas em filtro com $0,45 \mu \mathrm{m}$ de diâmetro de poro e todas as soluções utilizadas acidificadas (ácido nítrico suprapur Merck 1\%). Em seguida, as amostras foram analisadas em 2 métodos distintos:

$1^{\circ}$ ) Determinação de $\mathrm{Cr}, \mathrm{Ni}, \mathrm{Cd}$ e $\mathrm{Pb}$;

$\left.2^{\circ}\right)$ Determinação de $\mathrm{Fe}: \mathrm{O}$ isótopo de $\mathrm{Fe}$ de $\mathrm{m} / z=56$ foi determinado utilizando gás Hélio como gás de colisão para eliminação de interferência de Ar O.

\subsubsection{Procedimento Metodológico}

Para a determinação de elemento-traço seguiu-se a metodologia do Manual de Análises Físico-Químicas de Águas (LabAguas). A análise foi conduzida por 
espectrometria de massas com plasma indutivamente acoplado (ICP-MS), em equipamento Agilent, modelo 7500ce.

A determinação de Fe foi feita utilizando o sistema de eliminação de interferência (ORS) com introdução de gás He.

\subsection{Determinação de $\mathrm{H}_{2} \mathrm{O}_{2}$ Residual e Oxigênio Dissolvido}

O estudo de depuração acelerada de matéria orgânica através do uso de peróxido de hidrogênio foi conduzido em diferentes aplicações do peróxido em amostras de água de rio obtidas do Canal da Rua Gal. Garzón, no ponto de amostragem 3. As dosagens de peróxido foram testadas com o objetivo de obter as melhores condições do tratamento químico a fim de proporcionar aumento por suplementação de oxigênio dissolvido do rio, respeitando os limites de ecotoxicidade devido ao $\mathrm{H}_{2} \mathrm{O}_{2}$ para a vida aquática.

Os testes de determinação de peróxido de hidrogênio e oxigênio dissolvido foram realizados no Laboratório de Tratamento de Águas e Efluentes Industriais (DEQM / PUC - Rio).

\subsubsection{Procedimento Metodológico}

As amostras com as respectivas dosagens foram acondicionadas para tratamento em agitadores Jartest (Figura 24), devido à necessidade de testar diferentes dosagens em paralelo. Para simular a velocidade do corpo hídrico do local de retirada das amostras (movimento lêntico a estático), manteve-se no aparelho a velocidade de $20 \mathrm{rpm}$ durante as 24 horas dos experimentos. Para favorecer a homogeneização durante a aplicação das dosagens, foi utilizada uma maior velocidade de rotação no aparelho Jartest (120 rpm). Após adição e homogeneização das respectivas dosagens de peróxido, foram realizadas medições de oxigênio dissolvido e $\mathrm{H}_{2} \mathrm{O}_{2}$ residual. 


\subsubsection{Dosagens de Peróxido de hidrogênio}

Os experimentos foram realizados adicionando diferentes quantidades de reagente $\mathrm{H}_{2} \mathrm{O}_{2}$ P.A (50\%), previamente diluído em 1 litro de água destilada. $\mathrm{O}$ peróxido de hidrogênio fornecido pela Peróxidos Brasil Ltda foi adicionado para o preparo de diferentes dosagens: $[1,0] ;[1,5] ;[3,0] ;[5,0] ;[11,0] ;[15,0]$ e $[20,0] \mathrm{mg}$ $\mathrm{H}_{2} \mathrm{O}_{2} \mathrm{~L}^{-1}$.

\subsubsection{Determinação da concentração de Peróxido de hidrogênio residual}

O peróxido de hidrogênio foi quantificado através de um refletômetro RQFlex Plus (marca Merck). O limite de leitura das concentrações do oxidante no aparelho é de até $20,0 \mathrm{mg}$. $\mathrm{L}^{-1}$.

Para determinação das concentrações do peróxido de hidrogênio, foi utilizada uma fita reativa do kit de análise, sendo estas tiras imersas diretamente na solução estudada, sendo imediatamente medida no refletômetro.

\subsubsection{Determinação da concentração de Oxigênio dissolvido}

O oxigênio dissolvido das amostras foi medido através de oxímetro portátil de luminescência da marca HACH HQ 40d (Figura 25), medindo-se simultaneamente a temperatura da água e \% de saturação de OD. A medição ocorreu em conjunto á de peróxido residual. 


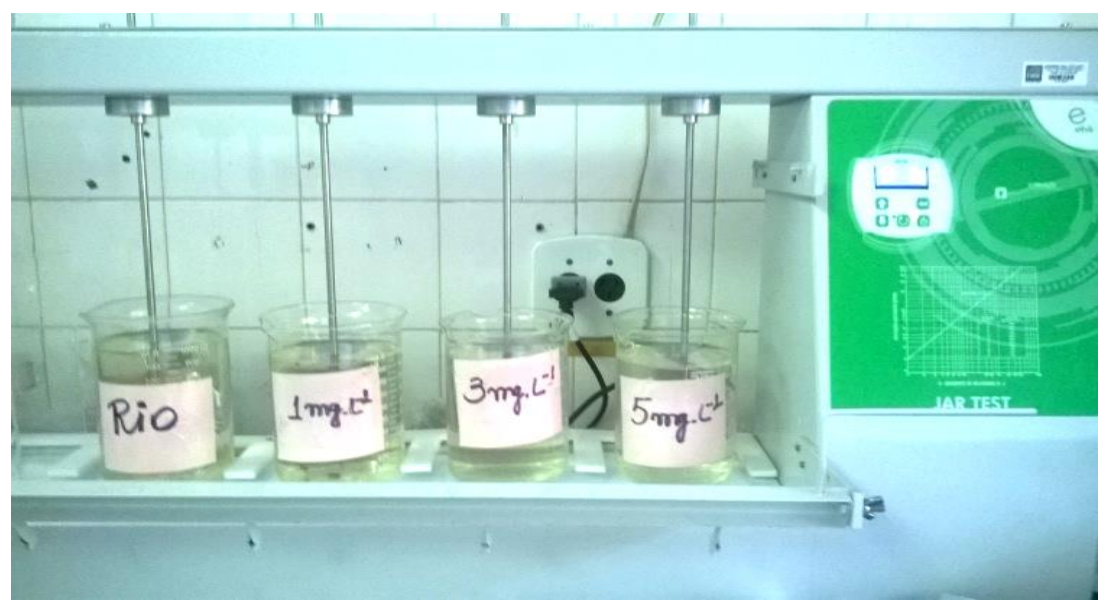

Figura 24 - Equipamento Jartest utilizado durante homogeneização das amostras com o peróxido de hidrogênio.

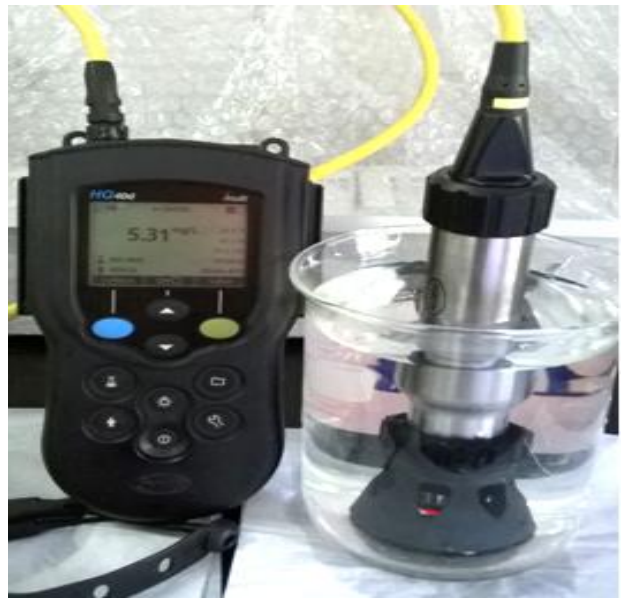

Figura 25 - Medição de oxigênio dissolvido por oxímetro portátil de luminescência.

\subsubsection{Determinação do pH}

$\mathrm{O} \mathrm{pH}$ das amostras foi monitorado antes da dosagem do $\mathrm{H}_{2} \mathrm{O}_{2}$ e ao término dos testes através do pH-metro marca Metrohm-827.

\subsubsection{Tempo de reação dos experimentos}

O tempo de reação entre a água do rio e o peróxido alimentado foi fixado em 24 horas, com leituras de oxigênio dissolvido e peróxido residual no decorrer desse tempo reacional. 


\section{Resultados e Discussão}

\subsection{Precipitação}

Os valores de precipitação dos meses ocorridos durante este estudo (agosto a janeiro, 2014/2015), não foram homogêneos e regulares (Figura 26), ocorrendo menos chuvas do que o esperado em comparação a anos anteriores.

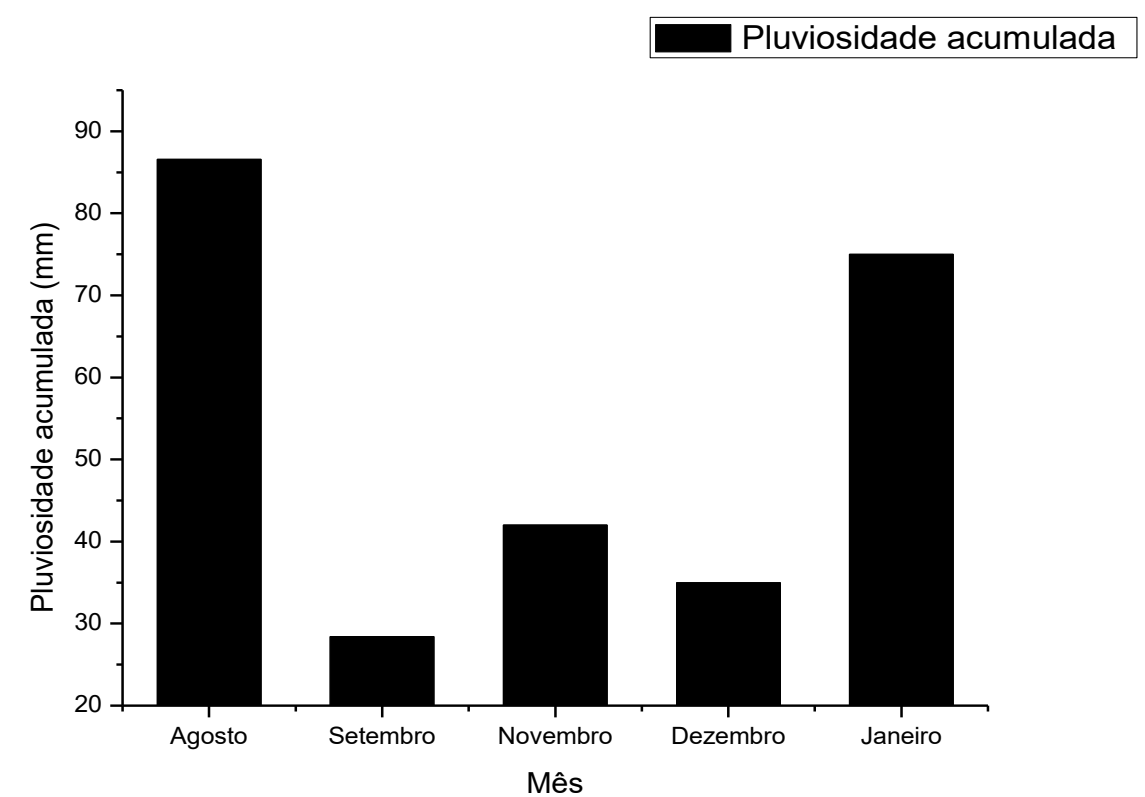

Figura 26 - Dados de precipitação dos meses de coleta de agosto a janeiro (2014/2015). Fonte. Adaptado de Instituto Nacional de Meteorologia (INMET, 2014) - Estação Convencional do Jardim Botânico do Rio de Janeiro.

Os valores de precipitação citados durante a discussão dos resultados são referentes ao acumulado do dia de cada coleta baseados nos dados fornecidos pelo Instituto Nacional de Meteorologia (INMET) da Estação Convencional do Rio de Janeiro (estação do Jardim Botânico) e pela Fundação Rio - Águas.

\subsection{Avaliação da qualidade da água do Canal da Rua Gal. Garzón}

Os parâmetros utilizados para quantificação da matéria orgânica neste estudo foram a DBO (demanda bioquímica de oxigênio) e o COT (carbono 
orgânico total). Foram realizadas análises de SST (sólidos suspensos totais), porém não se avaliou a fração orgânica e inorgânica, somente a concentração total. Foram também analisados fósforo total e elementos - traço a fim de comparação, em algumas coletas.

A Tabela 4 apresenta os resultados para DBO, COT e SST obtidos a partir de diferentes coletas realizadas no ponto de amostragem 3 do Canal da Rua Gal. Garzón. Os resultados indicam uma grande variabilidade das concentrações obtidas entre os períodos chuvoso e seco.

Tabela 4 - Valores de COT, SST e DBO no ponto 3 do Canal da Rua Gal. Garzón em período seco e chuvoso.

\begin{tabular}{|c|c|c|c|c|c|}
\hline $\begin{array}{c}\text { Local de } \\
\text { Coleta }\end{array}$ & Coleta / mês & $\begin{array}{c}\text { Precipitação de } \\
\text { Chuva } \\
\text { (mm/dia) }\end{array}$ & $\begin{array}{c}\text { Carbono } \\
\text { Orgânico } \\
\text { Total } \\
\text { (COT) }\end{array}$ & $\begin{array}{c}\text { Sólidos } \\
\text { Suspensos } \\
\text { Totais } \\
\text { (SST) }\end{array}$ & $\begin{array}{c}\text { Demanda } \\
\text { Bioquímica } \\
\text { de Oxigênio } \\
\text { (DBO) }\end{array}$ \\
\hline \multirow{9}{*}{ 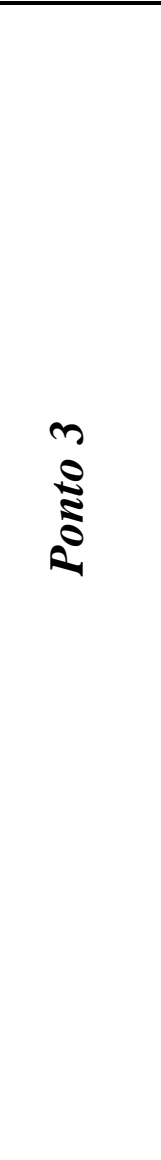 } & $\begin{array}{c}\text { C1/ } \\
\text { Agosto }\end{array}$ & 0,8 & - & - & 2,19 \\
\hline & $\begin{array}{c}\mathbf{C 2} / \\
\text { Setembro }\end{array}$ & $<0,5$ & 0,98 & 4 & 1,4 \\
\hline & $\begin{array}{c}\text { C3/ } \\
\text { Novembro }\end{array}$ & $<0,5$ & - & - & 24,1 \\
\hline & $\begin{array}{c}\text { C4/ } \\
\text { Novembro }\end{array}$ & 2,4 & 19,84 & 26 & - \\
\hline & $\begin{array}{c}\mathbf{C 5} / \\
\text { Dezembro }\end{array}$ & 0 & 4,71 & 16 & 25,3 \\
\hline & $\begin{array}{c}\text { C6/ } \\
\text { Dezembro }\end{array}$ & 0 & 2,13 & 3 & - \\
\hline & $\begin{array}{c}\text { C7/ } \\
\text { Janeiro }\end{array}$ & 13,2 & 6,76 & 24 & - \\
\hline & \multicolumn{2}{|c|}{ DP } & 7,58 & 10,81 & 13,24 \\
\hline & \multicolumn{2}{|c|}{$\mathrm{CV}(\%)$} & 110,81 & 74,04 & 99,92 \\
\hline
\end{tabular}


$\mathrm{Na}$ tabela, DP representa desvio padrão e CV representa coeficiente de variação. Os resultados das coletas C2,C4,C5, C6 e C7 foram utilizados para os cálculos de DP e CV dos parâmetros de COT e SST. Para o parâmetro de DBO, as coletas utilizadas para calcular DP e DV foram C1, C2, C3 e C5.

O coeficiente de variação observado de COT e SST indica que as concentrações de COT foram as que apresentaram maior variação ao longo das medições, resultado que sugere a existência de uma heterogeneidade em relação às coletas em tempo seco e chuvoso. Observa-se que os valores de CV (\%) são relativamente altos, indicando inconstância das concentrações dos parâmetros ao longo das coletas e das taxas de precipitação. Essa variabilidade era esperada devido às intervenções antrópicas (evidência visual de contaminação por esgoto) recorrentes na área de estudo.

A coleta 6 apresentada na Tabela 4 foi realizada durante evento de entrada da maré da Praia do Leblon pelo Canal da Visconde de Albuquerque, onde através de manobras de comportas, a água foi conduzida até o Canal da Gal. Garzón, ocorrendo então no ponto 3 do Canal a junção da água do mar com os rios Rainha, Macacos e Cabeça. Devido à alta vazão, mesmo com a comporta fechada, ocorria deságue para a Lagoa Rodrigo de Freitas por transbordo. Na Figura 27 é possível observar a transparência da água, o que indica baixa quantidade de sólidos suspensos, provavelmente devido à diluição e a não ocorrência de chuva no dia. Este evento ocorre esporadicamente, apenas quando há elevação significativa da maré, em que se constata a existência de procedimento de abertura da comporta do Canal da Av. Visconde de Albuquerque (por onde normalmente escoa o Rio Rainha) para a entrada de água do mar da praia do Leblon quando há elevação da maré, ocorrendo abertura da comporta, supostamente para que não ocorra pressão da água sobre esta. 

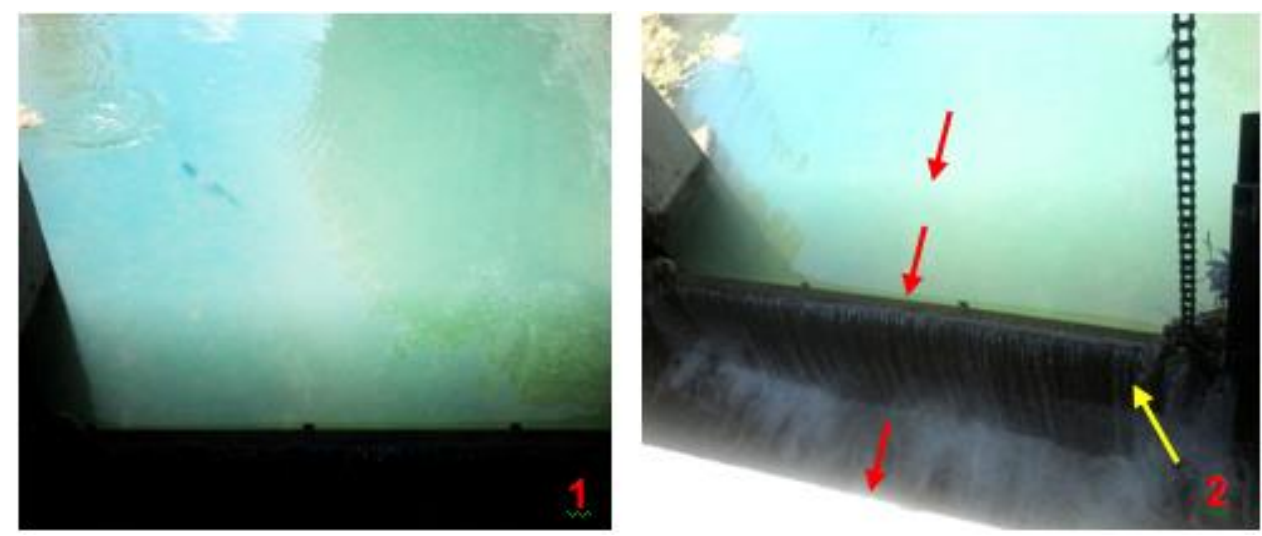

Figura 27 - (1) Aspecto da água do Canal da Rua Gal. Garzón em evento de contribuição dos três rios da Bacia (Cabeças, Macacos e Rainha) e água do mar. (2) Percebe-se que mesmo com a comporta fechada, ocorria transbordo para a LRF. A seta em amarelo indica a barreira da comporta; a seta em vermelho indica o fluxo da água do canal desaguando para a Lagoa.

\subsubsection{Resultados de ressuspensão de sedimentos no ponto de amostragem 3.}

Durante a coleta $\mathrm{C} 2$, em cuja ocasião a precipitação ficou abaixo de 0,5 mm, foi realizado pela Prefeitura da cidade uma operação de dragagem, onde se pode observar nas Figuras 28, 29 e 30 a seguir a variação das concentrações de DBO, SST e COT antes e após a dragagem. A coleta ocorreu após o término da operação (cerca de 1 hora após).

Observa-se nas Figuras 28 e 29 menores valores de DBO e TOC no Ponto 3 em relação ao ponto 1 (antes da operação de dragagem), indicando a ocorrência de diluição. LUCAS e CUNHA (2007) encontraram valores de DBO semelhantes no mesmo canal de estudo, onde no percurso do ponto 1 ao 2 , foi possível observar uma tendência de diminuição dos valores. Os autores não realizaram medições no canal após o Ponto 2 (local de confluência dos rios Cabeça com o dos Macacos). É citado ainda pelos autores a observação de maiores valores à montante do Canal Gal. Garzón, onde o Rio dos Macacos não havia ainda desaguado no Canal, demonstrando um processo de diluição durante o percurso do rio ao longo do Canal Gal. Garzón. 
Após o evento de dragagem, obteve-se um valor de 7,0 $\pm 0,7 \mathrm{mg} \cdot \mathrm{L}^{-1}$ de DBO, valor esse acima do permitido pelo CONAMA 357/05. Este resultado é justificado pela necessidade de consumo de OD através da demanda de lodo do fundo que foi revolvida no canal para oxidação da matéria orgânica contida nos sólidos de fundo (VON SPERLING, 2005). Segundo HARREMOES (1982), frações significativas de esgoto também estão associadas à matéria em suspensão e podem também estar sujeitos ao processo de sedimentação.

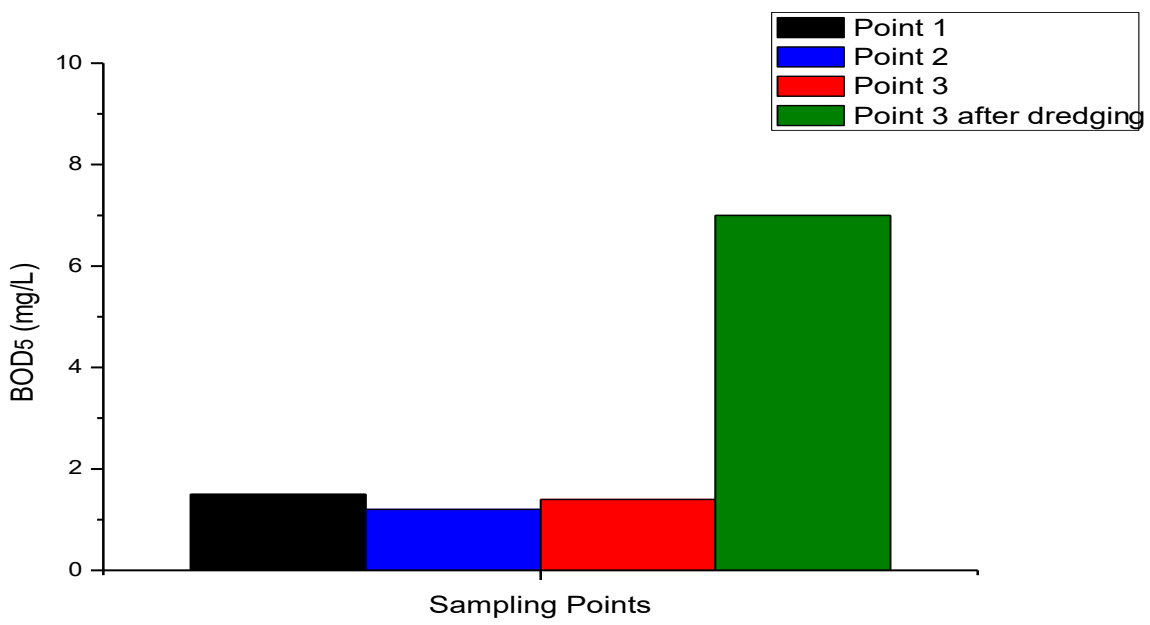

Figura 28 - Distribuição dos dados de DBO5 no Canal da Rua Gal. Garzón em três pontos (Ponto1; Ponto 2; Ponto 3). As amostras do Ponto 3 são referentes à antes e após operação de dragagem realizada pela Prefeitura. $O$ volume de precipitação de chuva do dia ficou abaixo de $0,5 \mathrm{~mm}$. Não foi observado durante a coleta lançamento de esgoto ou contribuição do Rio Rainha pelo Canal do Jockey.

Os valores de COT (Figura 29) e SST (Figura 30) também foram superiores após a operação de dragagem. Segundo LOPARDO et al. (2008), além da poluição difusa e pontual nos corpos hídricos, o material orgânico pode ser resultado também de ressuspensão de sedimento, indicando uma relação direta com a presença de sólidos na água.

Para LUCAS e CUNHA (2007), esse acúmulo de materiais no canal ocorre devido a pouca variação de declividade da região, ocorrendo baixa energia do fluxo neste ponto, sofrendo influências do assoreamento e deposição de sedimentos transportados pelos rios. Devido a esta baixa energia de fluxo e alta tendência ao acúmulo, são necessárias operações rotineiras de dragagem no local. 


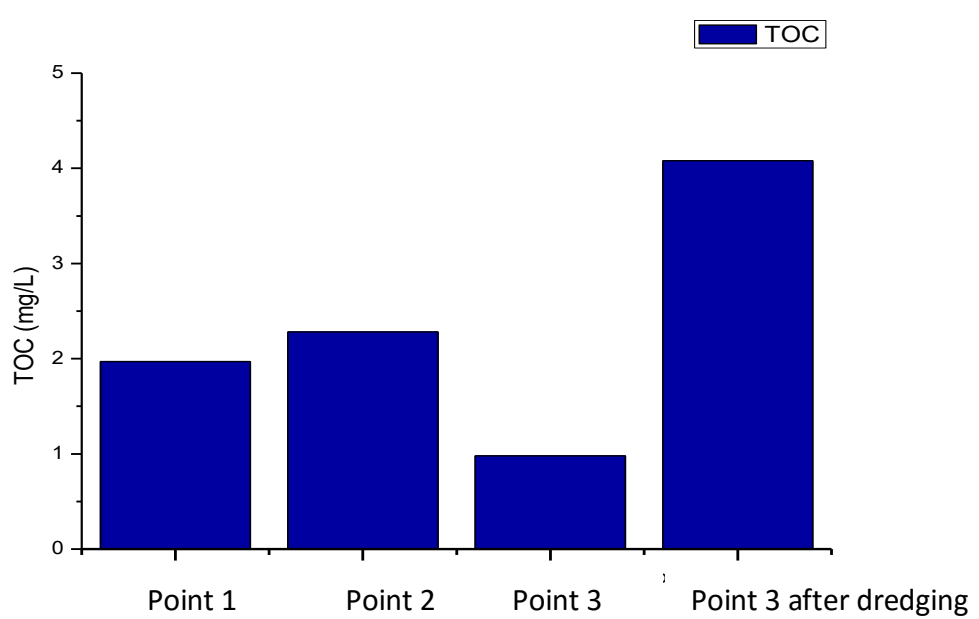

Figura 29 - Distribuição dos dados de COT no Canal da Rua Gal. Garzón em três pontos (Ponto1; Ponto 2; Ponto 3). As amostras do Ponto 3 são referentes à antes e após operação de dragagem realizada pela Prefeitura. O volume de precipitação de chuva do dia ficou abaixo de $0,5 \mathrm{~mm}$. Não foi observado durante a coleta lançamento de esgoto ou contribuição do Rio Rainha pelo Canal do Jockey.

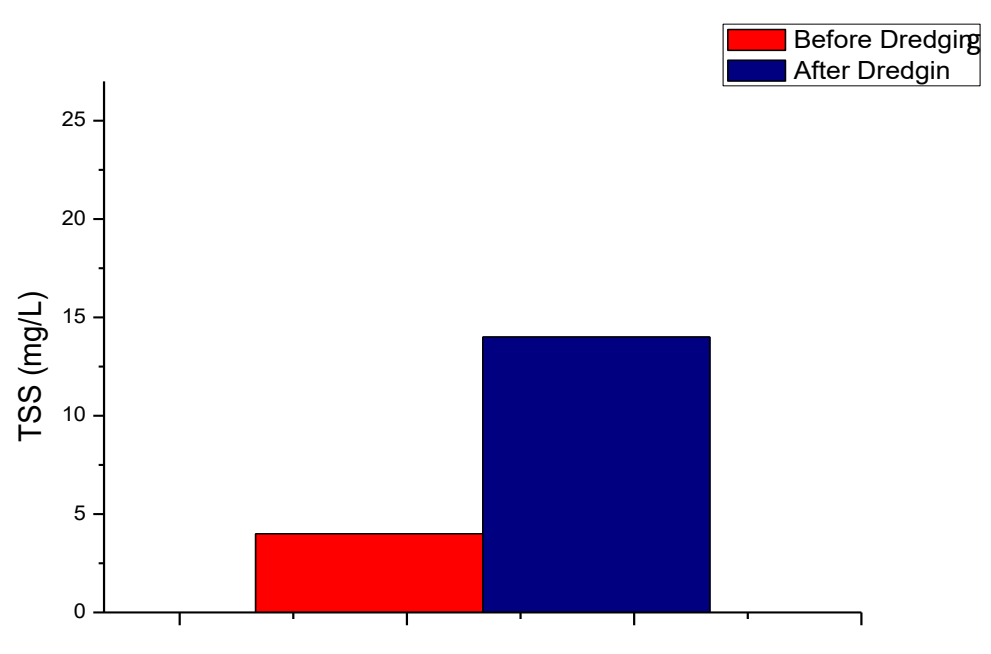

Point 3

Figura 30 - Distribuição dos dados de SST no Canal da Rua General Garzón no Ponto 3 antes e após operação de dragagem realizada pela Prefeitura. O volume de precipitação de chuva do dia ficou abaixo de $0,5 \mathrm{~mm}$. Não foi observado durante a coleta lançamento de esgoto ou contribuição do Rio Rainha pelo Canal do Jockey.

\subsubsection{Concentrações de SST, COT e DBO nos pontos de amostragem}

\section{1 e 3}

Para verificar a influência da precipitação, analisou-se SST, COT e DBO no Ponto 1 e no Ponto 3 a fim de comparação. 
Buscou-se avaliar a ocorrência de diferenças significativas $(\mathrm{p}<0,05)$ das concentrações de COT, SST e DBO entre as coletas realizadas em tempo chuvoso e tempo seco aplicando-se o teste estatístico não paramétrico de Kruskal Wallis através do programa R Core Team (2014). Porém, os resultados dos testes não conseguiram capturar diferenças que poderiam realmente existir, devido ao tamanho da amostra (a quantidade de coletas foi insuficiente, principalmente devido à baixa ocorrência de chuvas ao longo do estudo). Entretanto, não significa que não possa ter havido diferenças em alguns casos, como indicado no gráfico de Boxplot (Figura 37). Estes gráficos (também chamados de diagramas de caixa) são usados quando se quer comparar os valores de uma variável contínua em relação aos valores de outra variável categórica.

Os resultados apresentados na Figura 31 demonstram um aumento nos valores de DBO do Ponto 1 ao Ponto 3 em dois momentos; um em tempo seco, provavelmente devido ao lançamento pontual através do canal do Jockey Clube observado no dia da coleta (DBO 25,3 $\pm 4,1 \mathrm{mg} . \mathrm{L}^{-1}$ ), e outro em evento de baixa precipitação $(<0,5 \mathrm{~mm})$ onde foi observado novamente contribuição do Canal do Jockey no dia da coleta (DBO 24,1 0,6 mg. $\mathrm{L}^{-1}$ ), além da constante contribuição do Rio Cabeça ao canal para todas as amostragens. Ambos os resultados violaram o valor limite estabelecido pela Resolução CONAMA 357 (Tabela 5).

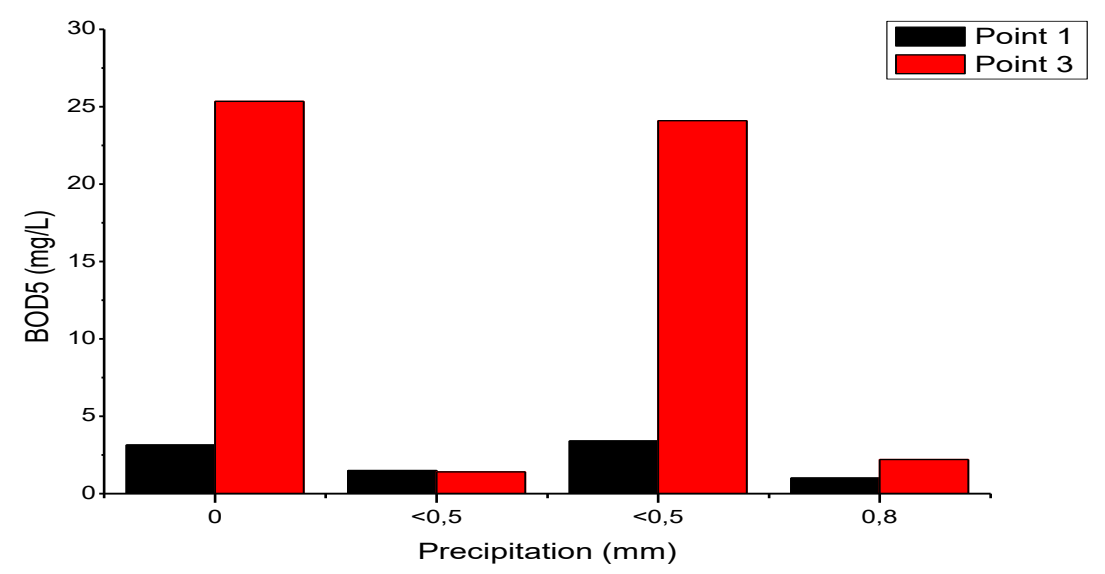

Figura 31 - Distribuição dos dados de DBO5 (mg/L) versus precipitação de chuva (mm) a partir de amostras coletadas nos meses de agosto a dezembro (2014). 
Segundo MACHADO (2009), deve-se salientar que principalmente neste trajeto dos rios pelo Canal da General Garzón, ocorrem lançamentos de esgoto in natura decorrentes de ligações irregulares que são incorporados a aportes de microdrenagens pluviais. Indícios de lançamento de esgotos no Canal foram apresentados pelo autor em seu estudo de 2009, encontrando valores de coliformes fecais próximo ao Ponto 3 acima dos padrões determinados pela CONAMA 357/05, fato este que causa exposição nociva a toda população, além de gerar degradação dos rios drenados e ao corpo receptor da Bacia. DE PAULA (2009) também apresentou em seus estudos valores de DBO acima do estabelecido pela Legislação, obtendo concentrações médias de DBO de 19,8 mg.L $L^{-1}$ obtidos no Canal da Rua Gal. Garzón (o autor não especificou a localização de amostragem do Canal).

Vale destacar que as concentrações de DBO para o Ponto 1 apresentaram em todas as coletas valores abaixo do limite estabelecido pela Legislação.
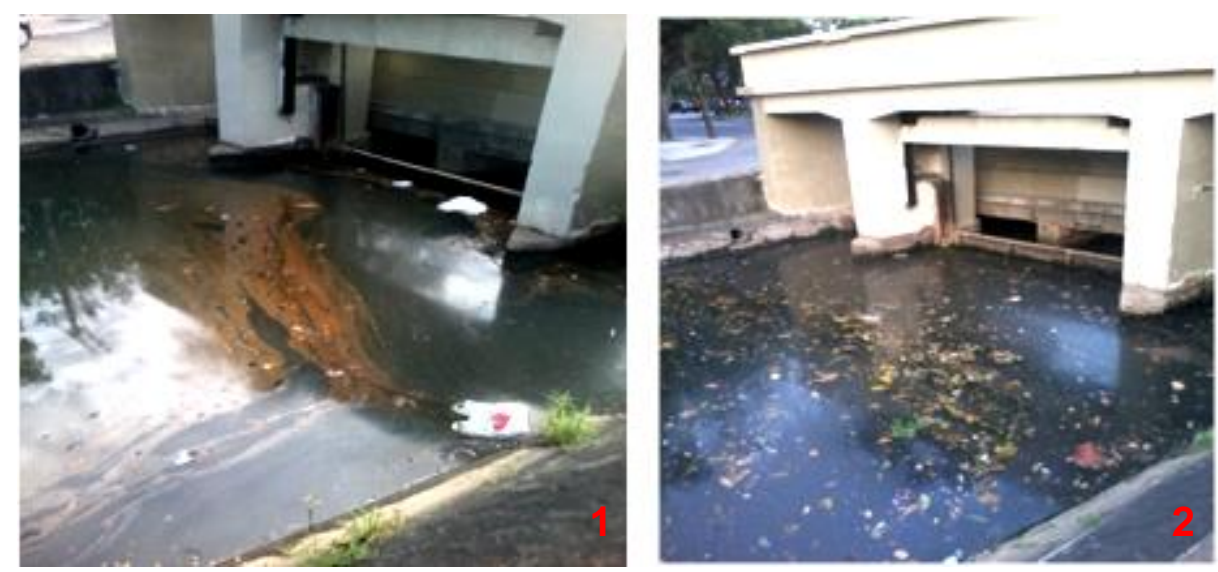

Figura 32 - Aspecto da água no Ponto 3 do Canal da Rua Gal. Garzón em dois momentos: (1) Coleta 3 realizada após taxa de precipitação de chuva abaixo de $0,5 \mathrm{~mm}$, com contribuição do Canal do Jockey e (2) Coleta 5 realizada em tempo seco, com provável lançamento pontual contribuído através do canal do Jockey Clube. 
Tabela 5 - Valores limites preconizados na Resolução CONAMA 357/2005 para água doce de Classe II.

\begin{tabular}{|c|c|}
\hline Parâmetros & Concentrações $\left(\mathbf{m g} . \mathrm{L}^{-1}\right)$ \\
\hline $\mathrm{DBO}_{5}$ & Até $5 \mathrm{mg} \cdot \mathrm{L}^{-1}$ \\
\hline $\mathrm{OD}$ & A partir de $5 \mathrm{mg} . \mathrm{L}^{-1}$ \\
\hline $\mathrm{P}_{\text {total }}$ & $\begin{array}{c}\text { Até } 0,030 \mathrm{mg} \cdot \mathrm{L}^{-1} \text { para ambientes lênticos; } \\
\text { Até } 0,050 \mathrm{mg} \cdot \mathrm{L}^{-1} \mathrm{em} \text { ambientes intermediários }\end{array}$ \\
\hline $\mathrm{Fe}$ & Até $0,3 \mathrm{mg} \cdot \mathrm{L}^{-1}$ \\
\hline
\end{tabular}

As Figuras 33 e 35 representam respectivamente os valores referentes à SST e COT das coletas realizadas em diferentes precipitações de chuva nos pontos 1 e 3. Observou-se maiores concentrações de sólidos suspensos e COT principalmente no ponto 1 durante as coletas de maior precipitação (C4 e C7), sendo provavelmente resultado de um maior carreamento durante elevadas precipitações. Para a coleta em tempo seco (coleta 5), ocorria no momento da amostragem do ponto 3 evidência visual de lançamento de esgoto através do canal do Jockey Clube, o que ocasionou na elevação das concentrações de sólidos em suspensão do local. Este fato pode ser justificado segundo DEZOTTI (2008), devido ao lançamento de um despejo de origem doméstica ou industrial em um corpo receptor provocar no ponto de lançamento um aumento da concentração de SS (sólidos em suspensão) e material orgânico (geralmente adsorvido nas partículas de sólidos), ocorrendo, por conseguinte, uma redução da concentração de oxigênio dissolvido devido à demanda necessária para oxidação da matéria orgânica.

O ponto 3 pode ainda ter tais concentrações de poluentes orgânicos adicionadas à contribuição do tributário Rio Cabeça. Então, os resultados do ponto 3 podem mascarar os efeitos da intensidade da precipitação sobre o rio em estudo devido à contaminação pontual de esgoto verificada (visualmente) durante algumas coletas. 
Ao observar o efeito da precipitação sobre a [SST] somente no ponto 1 (Figura 34), é possível perceber um progressivo aumento das concentrações do parâmetro em decorrência de maiores taxas de precipitação. Essa observação é mais nítida devido a este local de amostragem sofrer menos intervenções pontuais (ou em menores concentrações) em relação ao ponto de amostragem 3. Percebe-se um possível efeito de diluição para a coleta de maior precipitação (13,2 mm). Ao considerar também o tempo (dias) sem chuva anterior à coleta, a coleta de 2,4 mm de chuva foi a que apresentou maior tempo sem precipitação (17 dias sem chuva), em comparação à coleta de 13,2 mm; o que pode ter potencializado o acúmulo de sólidos, sendo após a chuva carreados em maior concentração devido à intensidade da precipitação.

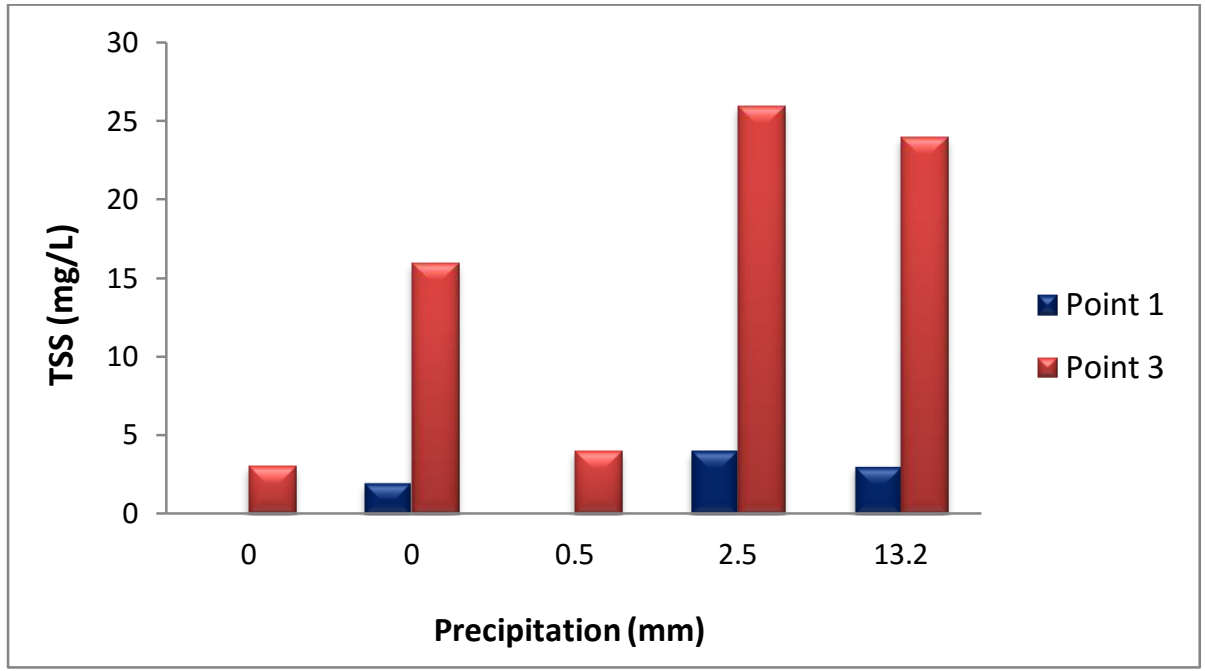

Figura 33 - Distribuição dos dados de SST versus precipitação de chuva $(\mathrm{mm})$ a partir de amostras coletadas nos meses de agosto a janeiro (2014- 2015). 


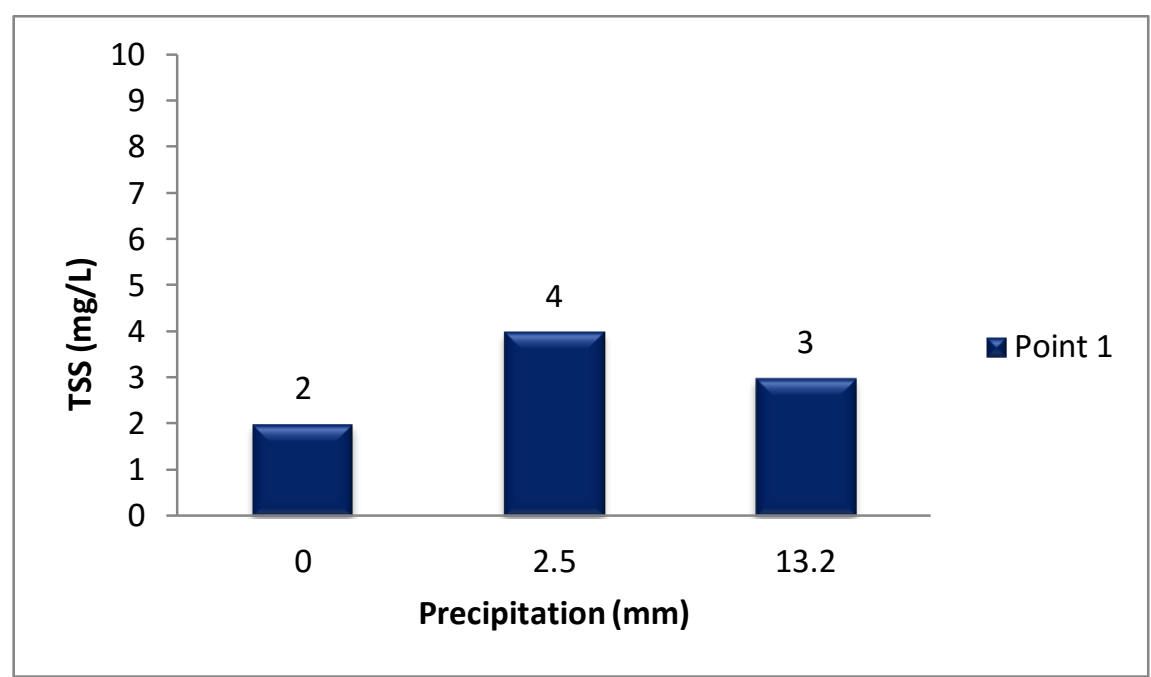

Figura 34 - Distribuição dos dados de SST versus precipitação de chuva $(\mathrm{mm})$ a partir de amostras coletadas no ponto de amostragem 1 nos meses de novembro a janeiro (2014 - 2015).

A. LIU et al. (2013) atribuem uma maior concentração de poluentes nas águas pluviais durante maiores precipitações à energia cinética relativamente mais elevada de eventos de alta intensidade de chuva, resultando em mais poluentes transportados devido à maior desagregação dos sólidos. Na Figura 36 (referente ao ponto 1), percebe-se uma relação de proporcionalidade entre as taxas de precipitação (de 0,5 a 13,2 mm) e as concentrações de carbono na água. À medida que ocorre aumento dos níveis de precipitação, há um aumento das concentrações de carbono orgânico para o rio, decorrente provavelmente do escoamento superficial em maiores volumes de chuva.

Os resultados relativos à [COT] no ponto 3 (Figura 35) apresentam menores concentrações durante a $C 7(13,2 \mathrm{~mm})$, em relação a $\mathrm{C} 4(2,4 \mathrm{~mm})$. VIOLA (2008), ao analisar amostras da Bacia do Rio Doce (MG) também de acordo com as variações temporais, obteve valores de COT menores em eventos de maior precipitação. Segundo o autor, os resultados foram atribuídos pelo processo de diluição. Porém, para as coletas observadas neste estudo, o processo de diluição parece não ter sido o responsável pelos resultados obtidos. Provavelmente ocorreu o mesmo que para os sólidos suspensos neste ponto, onde a contribuição de esgoto acrescentada ao carreamento de materiais durante a precipitação favoreceu este aumento de [COT]. Percebe-se então que os resultados 
obtidos no ponto 3 podem interferir na avaliação da influência da precipitação sobre o carreamento de poluentes orgânicos para o canal.

Apesar dos resultados apresentarem valores de COT elevados (C4 e C7: 19,84 e $6,76 \mathrm{mg} . \mathrm{L}^{-1}$ respectivamente) no ponto 3 em relação às outras coletas, são segundo LIBÂNIO et al. (2000), característicos de águas superficiais, onde o teor de COT pode variar de 1 a $20 \mathrm{mg} . \mathrm{L}^{-1}$. Para CLAR et al. (2004), as elevadas concentrações de carbono carreadas para os corpos hídricos durante as precipitações em águas de movimento lento podem sim apresentar um problema, já que ao se decomporem podem esgotar o oxigênio dissolvido do corpo hídrico.

A qualidade das águas do canal já foi citada por LUCAS e CUNHA (2007), onde destacaram em seus trabalhos sobre o Rio dos Macacos, o lançamento de esgotos durante o canal, principalmente próximo à comporta. Segundo os autores, pôde-se também observar que em períodos de chuva o canal apresenta maior contribuição de poluição, onde as águas passam a apresentar coloração escura devido ao esgoto e aos sedimentos em suspensão.

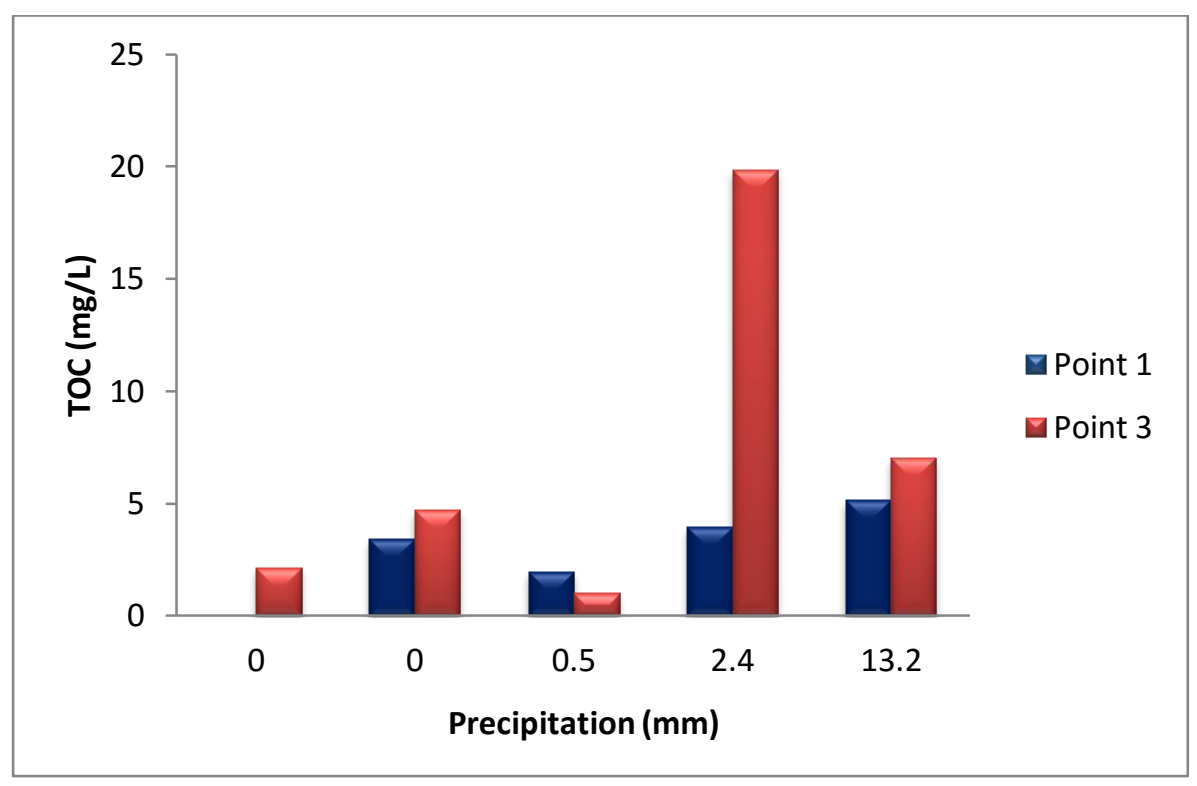

Figura 35 - Distribuição dos dados de COT versus precipitação de chuva $(\mathrm{mm})$ a partir de amostras coletadas nos meses de agosto a janeiro (2014- 2015). 


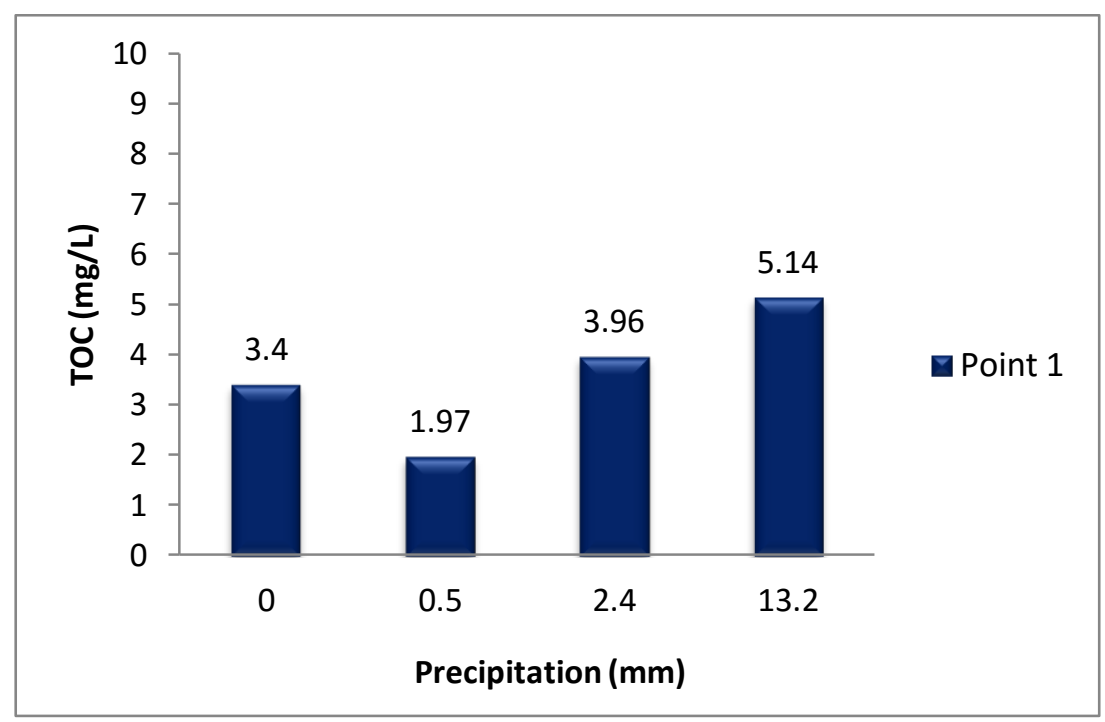

Figura 36 - Distribuição dos dados de TOC versus precipitação de chuva $(\mathrm{mm})$ a partir de amostras coletadas no ponto de amostragem 1 nos meses de setembro a janeiro (2014 2015).

No Ponto 1, apesar do carreamento de poluentes e de prováveis lançamentos de esgotos provenientes do percurso do Rio dos Macacos, não foi observado uma variação significativa dos parâmetros analisados quanto aos valores obtidos no Ponto 3 .

A [SST] foi a variável testada que mais se aproximou de $\mathrm{p}<0,05$, apresentando diferença a $p<0.14$ em comparação com as [COT] e [DBO] durante o período chuvoso no ponto 3 , demonstrando assim, uma maior dinâmica em relação às chuvas. A figura 37 mostra as diferenças de medianas entre a variável. Observa-se então que a precipitação deve ter influenciado diretamente na elevação da concentração dos sólidos suspensos obtidos neste local de estudo. 


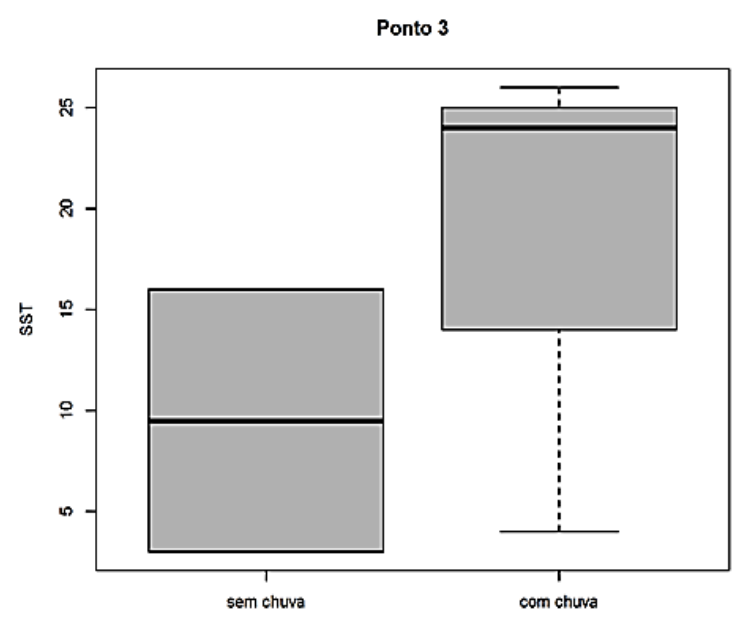

Figura 37 - Resultados de mediana de [SST] no ponto 3 em relação às coletas de tempo seco e chuvoso.

Então, os resultados discutidos até agora sugerem que as maiores concentrações dos parâmetros observados no P1 parecem sofrer principalmente interferência dos efeitos da pluviosidade (chuvas carreando substâncias para os rios), enquanto que as maiores concentrações dos parâmetros observados no P3 parecem sofrer principalmente interferência de dois fatores: (1) os efeitos da pluviosidade e (2) rios tributários com alta carga orgânica (Cabeça no ponto 2 e ás vezes o Rainha através do canal do Jockey) e a contaminação por fontes pontuais (pelo canal do Jockey e esgotos). Adiciona-se a esses fatores o fato de no Ponto 3 a comporta estar constantemente fechada, o que prejudica a taxa de reaeração de oxigênio neste ponto, devido ao movimento lêntico das águas, ocorrendo somente reaeração por difusão. Ou seja, além da acumulação de poluentes, ocorre uma lenta reposição de OD e um alto consumo deste na biodegradação de poluentes.

\subsubsection{Ponto de amostragem 2- contribuição do Rio Cabeça ao Canal da Rua Gal. Garzón}

A Figura 38 apresenta os resultados de COT obtidos em coleta de baixa precipitação $(<0,5 \mathrm{~mm}$ de chuva) e coleta de maior precipitação deste estudo (13,2 mm de chuva) referente aos Pontos 1,2 e 3. 


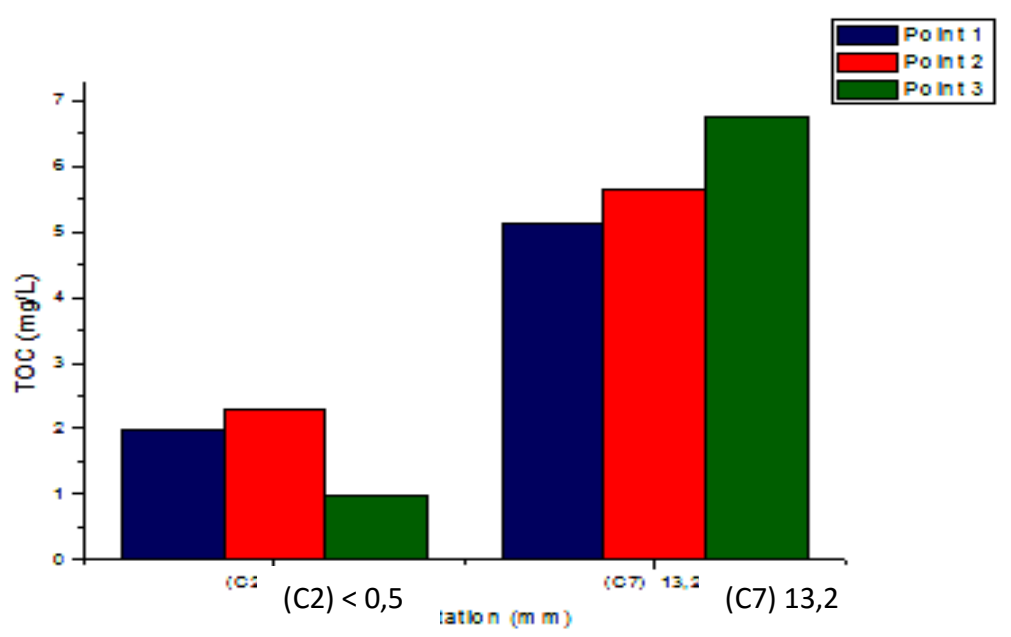

Figura 38 - Distribuição dos dados de concentração de COT obtidas em coleta de precipitação de chuva abaixo de $0,5 \mathrm{~mm}$ (Coleta 2) e coleta de precipitação de 13,2 $\mathrm{mm}$ (Coleta 7) no Canal da Rua Gal. Garzón nos Pontos 1, 2 e 3.

Primeiramente, é possível observar na figura um aumento significativo de carbono orgânico para o corpo hídrico após evento de maior precipitação. Percebe-se também que a contribuição do Rio Cabeça ao Rio dos Macacos resultou em um pequeno aumento de material orgânico durante a coleta abaixo de 0,5 $\mathrm{mm}$ de chuva, sendo que posteriormente ao Ponto 2 ocorreu provavelmente um processo de diluição, sendo possível observar através da concentração encontrada no Ponto 3. O mesmo ocorreu para a coleta de maior precipitação (13,2 mm de chuva) para os pontos 1 e 2 . O Ponto 3 apresentou concentração de material orgânico um pouco maior, podendo-se atribuir tais concentrações à contribuição da maior vazão do Rio Cabeça ao Canal durante maiores precipitações e talvez outras fontes pontuais como já discutido anteriormente, ou mesmo variação de concentração decorrente da análise, não sendo possível afirmar o fator causador, já que a diferença de [COT] do Ponto 2 para o Ponto 3 foi de $1,6 \mathrm{mg} . \mathrm{L}^{-1}$.

Apesar de o Rio Cabeça possuir uma vazão média dez vezes menor que o Rio dos Macacos, ele ainda é responsável por boa parcela da carga orgânica que chega ao canal da Rua General Garzón (DE PAULA, 2009). Segundo o autor, após a ocorrência de grandes precipitações e aporte de águas residuais, ocorre o carreamento de grandes quantidades de sedimentos e matéria orgânica, o que irá consequentemente acarretar no aumento do consumo de oxigênio dissolvido. 
Para verificar a oxigenação das águas do Rio Cabeça no ponto de entrada ao Canal da Rua Gal. Garzón (Ponto 2), foram realizadas medições de oxigênio dissolvido tanto no Canal Gal. Garzón quanto no Canal da Av. Lineu de Paula Machado, onde situa-se o Rio Cabeça antes de desaguar ao Rio dos Macacos. As medições foram realizadas no mês de Janeiro (2015) em dia de 0,0 mm de precipitação, após 3 dias seguidos de chuva. A figura 39 apresenta os resultados.

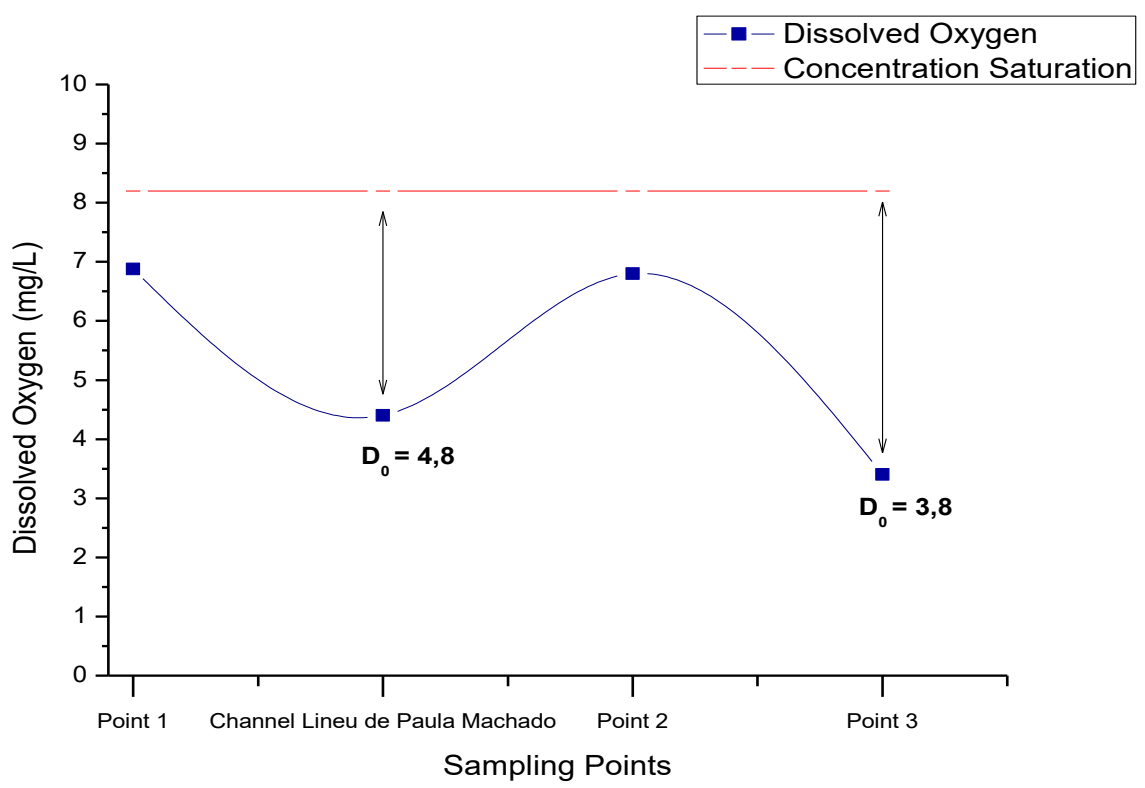

Figura 39 - Distribuição dos dados de oxigênio dissolvido nos pontos 1, 2 e 3 no Canal da Rua Gal. Garzón e no ponto do Canal da Av. Lineu de Paula Machado (ponto anterior à contribuição do Rio Cabeça ao Canal Gal. Garzón). As medições ocorreram após três dias seguidos de precipitação. Os valores de concentração de saturação da figura são baseados na tabela da EPA (2012) de concentração máxima de oxigênio dissolvido de acordo com variação da temperatura.

Observa-se na figura acima um déficit de oxigênio dissolvido $\left(\mathrm{D}_{0}\right)$ considerável nos pontos localizados no Canal da Av. Lineu de Paula Machado onde se encontra o Rio Cabeça, e no Ponto 3 do Canal da Rua Gal. Garzón, ambos abaixo do limite de OD estabelecido pela Resolução CONAMA 357/05 (> 5,0 mg. $\mathrm{L}^{-1}$ ). No ponto 2 (local a jusante do encontro do Rio Cabeça ao dos Macacos no Canal Gal. Garzón), já ocorre um aumento de OD devido ao encontro com as águas do Rio dos Macacos com maior oxigenação. Porém no Ponto 3, observa-se um novo decréscimo de OD, sendo este o ponto crítico de OD no Canal Gal. Garzón, provavelmente devido à mistura das concentrações de matéria orgânica 
aliadas ao baixo movimento das águas neste local do canal, o qual apresenta movimento quase estático, o que pode influenciar na baixa taxa de reoxigenação das águas, além de maior atividade microbiológica devido também às elevadas temperaturas características do verão.

Segundo BARROS et al. (2011), a dinâmica da desoxigenação e reaeração de corpos hídricos proporcionam o balanço da concentração de oxigênio dissolvido. Esta dinâmica é basicamente governada pelo coeficiente de desoxigenação, que varia de acordo com a composição e a concentração do material orgânico na água e pelo coeficiente de reaeração, sendo este altamente dependente das características geométricas do rio e de sua vazão. De acordo com TECHNO-BIO (2012), o ultimo segmento do Rio Cabeças correspondente ao canal da Av. Lineu de Paula Machado até o deságue no canal da Rua Gal. Garzón é o mais degradado, onde se observa o agravamento da poluição e do assoreamento. Para MACHADO (2009), o ponto 3 do Canal da R. Gal. Garzón, próximo á foz de seu deságue na LRF, é o ponto mais comprometido do rio dos Macacos, potencializado pelas intervenções anteriores na calha do rio e incorporando ainda, contribuições poluidoras importantes da macrodrenagem que deságuam neste trecho: canais da Av. Lineu de Paula Machado e, eventualmente através do canal do Jockey.

Atualmente o Rio dos Macacos tem suas águas menos poluídas, em decorrência principalmente de intervenções realizadas pela SMAC (Secretaria de Meio Ambiente da cidade do Rio de Janeiro), Fundação Rio-Águas e CEDAE (Companhia Estadual de Águas e Esgotos) a fim de diminuir o aporte de esgoto doméstico, apresentando uma qualidade superior de alguns anos atrás. Contudo, segundo DE PAULA (2009), o Rio Cabeça ainda tem suas águas visualmente poluídas, necessitando de intervenções públicas para melhoria de sua qualidade.

Sendo assim, o que pôde ser observado é uma contribuição relevante de matéria orgânica através do Rio Cabeça ao Canal da Rua Gal. Garzón, contribuindo para seu déficit de oxigênio. 


\subsubsection{Concentração de Fósforo total no Canal da Rua Gal. Garzón}

A concentração de Fósforo total foi analisada em dois momentos: (1) em tempo seco (C5), onde foi possível observar durante a amostragem poluição no Ponto 3 proveniente do canal do Jockey; e (2) em período de maior precipitação observada neste estudo (13,2 $\mathrm{mm}$ de chuva).

Para Parry (1998), o papel do fósforo na eutrofização dos recursos hídricos é essencial, e a origem deste nutriente a partir de áreas urbanas tem sido ultimamente colocada em relevância como indicador de qualidade da água.

LIU et al. (2013) citam a investigação de Miguntanna (2009) sobre os nutrientes de águas pluviais. O fósforo está intimamente associado com a carga dos sólidos fixos, que é fortemente aderida à superfície e exige eventos de elevada energia cinética para uma maior remoção. Isso significa segundo o autor, que uma maior quantidade (presente nas rochas como íon fosfato) é escoada por eventos com altas taxas de precipitação, devido à energia cinética superior e uma maior duração. Porém, a Figura 40 demonstra que as (ligeiramente) maiores concentrações de fósforo foram obtidas em coletas de tempo seco.

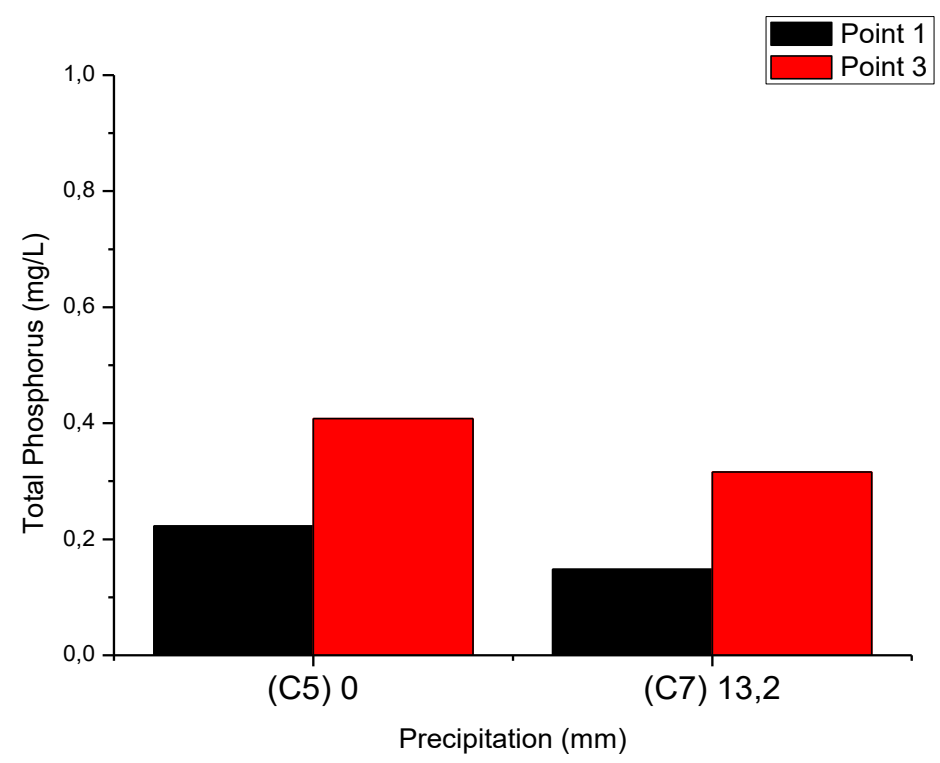

Figura 40 - Distribuição dos dados de concentração de Fósforo total nos Pontos 1 e 3 do Canal da Rua Gal. Garzón em tempo seco (coleta 5) e em elevada precipitação de chuva (coleta 7). 
Os fatores que possivelmente influenciaram os valores encontrados, foram o lançamento indevido de esgoto no Canal observado na Coleta 5 e a constante contribuição do Rio Cabeça ao Canal a partir do Ponto 2. A diluição ocorrida devido à maior taxa de precipitação na C7, também deve ser levada em consideração. Segundo TSUZUKI (2014), em seu estudo sobre descarga de poluentes, foram registradas partes significativas de sedimentos derivados de fontes difusas, enquanto que o lançamento de fósforo foi derivado principalmente de fontes pontuais.

Ambos os valores apresentaram concentrações elevadas, típicas de ambientes eutrofizados, violando os limites preconizados pelo CONAMA 357/05 (Valores do CONAMA 357/05 na Tabela 5) para ambientes lênticos, indicando ocorrência de interferência antrópica ao longo do canal. DE PAULA (2009) também apresentou em seus estudos valores obtidos de Fósforo total no Canal (o autor não especificou o ponto de amostragem e as condições climáticas do dia) acima do permitido pela Legislação, cujo valor médio foi de 5,6 mg. $\mathrm{L}^{-1}$.

Tabela 6 - Concentração de Fósforo total em tempo seco e em 13,2 mm de precipitação de chuva no Canal da Rua Gal. Garzón.

\begin{tabular}{|c|c|c|}
\hline \multirow{2}{*}{$\begin{array}{c}\text { Coletas/ Precipitação } \\
\text { (mm) }\end{array}$} & Ponto 1 & Pósforo total $\left(\mathbf{m g}^{-L^{-1}}\right)$ \\
\cline { 2 - 3 } & $0,22 \pm 0,003$ & $0,41 \pm 0,0035$ \\
\hline (C5) 0,0 & $0,15 \pm 0,003$ & $0,32 \pm 0,027$ \\
\hline (C7) 13,2 & & \\
\hline
\end{tabular}

\subsubsection{Elementos - traço}

Nas águas superficiais, o nível de ferro aumenta nas estações chuvosas devido ao carreamento de solos e a ocorrência de processos de erosão das margens. Também poderá (eventualmente) ser importante a contribuição devido a efluentes industriais, pois muitas indústrias desenvolvem atividades de decapagem química da camada oxidada (ferrugem) das peças antes de seu uso (CETEB, 2009). 
Para verificar a presença de metais, inclusive Fe nas águas do Canal nos pontos de amostragem 1 e 3, analisou-se as concentrações de $\mathrm{Cr}, \mathrm{Ni}, \mathrm{Cd}, \mathrm{Pb}$ e $\mathrm{Fe}$ para as coletas 5, 6 e 7. Todas as amostras com exceção do Fe apresentaram concentrações menores que $0,001 \mathrm{mg} / \mathrm{L}$.

Os resultados de Fe podem ser verificados na Tabela 7.

Tabela 7 - Concentração de Fe em tempo seco e em 13,2 mm de precipitação de chuva no Canal da Rua Gal. Garzón.

\begin{tabular}{|c|c|c|c|}
\hline \multirow{2}{*}{ Coleta } & \multirow{2}{*}{ Precipitação $(\mathrm{mm})$} & \multicolumn{2}{|c|}{$[\mathrm{Fe}] \mathrm{mg} . \mathrm{L}^{-1}$} \\
\cline { 3 - 4 } & & Ponto 1 & Ponto 3 \\
\hline C5 & 0,0 & 0,12 & 0,04 \\
\hline C6 & 0,0 & - & 0,05 \\
\hline C7 & 13,2 & 0,09 & 0,13 \\
\hline
\end{tabular}

Apesar de ter sido observada maior contribuição de $[\mathrm{Fe}]$ em evento de precipitação (13,2 mm de chuva), todas as concentrações de Fe encontradas no Canal tanto no Ponto 1 quanto no 3 apresentam-se dentro dos limites preconizados pela Resolução CONAMA 357/05 (Valores do CONAMA 357/05 na Tabela 5 ).

\subsection{Experimentos preliminares de aplicação de $\mathrm{H}_{2} \mathrm{O}_{2}$}

Testes preliminares sobre variação de OD ao longo do tempo (dias) na água de rio em eventos de chuvas intensas e em tempo seco foram realizados sobre amostras do Rio Rainha (pertencente à bacia hidrográfica da LRF) o qual recebe alguma contribuição de esgoto proveniente da vertente Gávea de áreas habitadas sem saneamento. Os pontos de coleta localizam-se dentro da Pontifícia Universidade Católica do Rio de Janeiro (PUC- Rio).

A seguir, na Figura 41, é apresentada a curva de depleção do oxigênio dissolvido ao longo de três dias de medição da água do rio sem adição de peróxido de hidrogênio. As amostras são características de tempo seco com alguma contribuição de esgoto. 


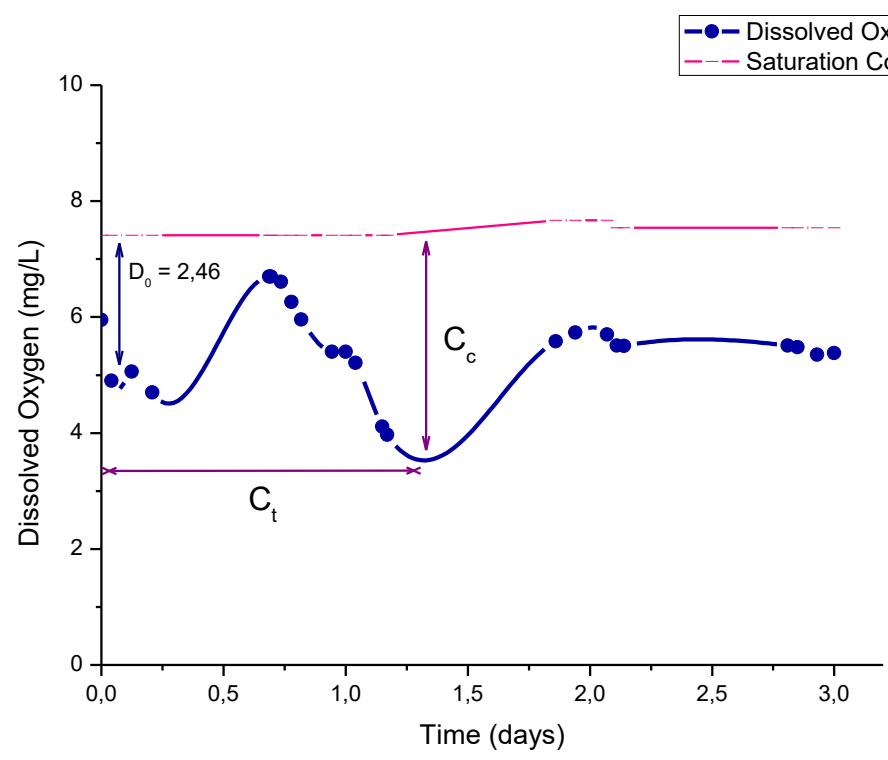

Figura 41 - Concentração de oxigênio dissolvido em água do rio Rainha sem adição de $\mathrm{H}_{2} \mathrm{O}_{2}$ durante três dias de medição. A [COT] foi de $3,0 \mathrm{mg} \cdot \mathrm{L}^{-1}$ e [CIT] 10,0 mg. $\mathrm{L}^{-1}$. A precipitação acumulada do dia foi $0,0 \mathrm{~mm}$ (RIO - ÁGUAS, 2014). Na figura D0 representa o déficit inicial de oxigênio dissolvido, Cc representa concentração crítica de oxigênio dissolvido e $\mathrm{Ct}$ representa tempo crítico. As concentrações de saturação do oxigênio dissolvido foram calculadas de acordo com a tabela EPA, 2012 (tabela de concentração de oxigênio dissolvido em relação à temperatura).

Observa-se na Figura 41 um déficit inicial de oxigênio $\left(\mathrm{D}_{0}\right)$ de $2,46 \mathrm{mg} . \mathrm{L}^{-1}$ e uma concentração crítica de oxigênio (Cc) de 3,97 mg.L $\mathrm{L}^{-1}$, valor este abaixo do estabelecido pela legislação (Resolução CONAMA 357/05) para manutenção da vida aquática. Esse baixo valor de OD observado mesmo durante a ausência de precipitação pode ser ocasionado pelo processo de depuração inicial, levando ao consumo excessivo de OD da coluna d'água. A curva apresenta um acréscimo de OD ao completar 12 horas (0,5 dias) e logo após, um decaimento. Esse acréscimo de OD não foi suficientemente sustentável, ocorrendo provavelmente um consumo microbiológico deste OD para a degradação da matéria orgânica, acarretando em seguida em um déficit crítico de oxigênio na água.

Para verificar a contribuição de OD à água do rio Rainha através de aplicações de peróxido de hidrogênio, foram adicionadas as seguintes dosagens: $[1,0],[3,0]$ e $[5,0]$ mg.L ${ }^{-1}$ (Figura 47). Observa-se na figura as curvas de elevação da [OD] na água do rio após as aplicações do peróxido. Foi necessário efetuar duas reaplicações do $\mathrm{H}_{2} \mathrm{O}_{2}$ para a dosagem de $1,0 \mathrm{mg} . \mathrm{L}^{-1}$ e uma reaplicação para 
as dosagens de $[3,0]$ e $[5,0] \mathrm{mg} . \mathrm{L}^{-1}$ devido ao seu esgotamento durante as medições.

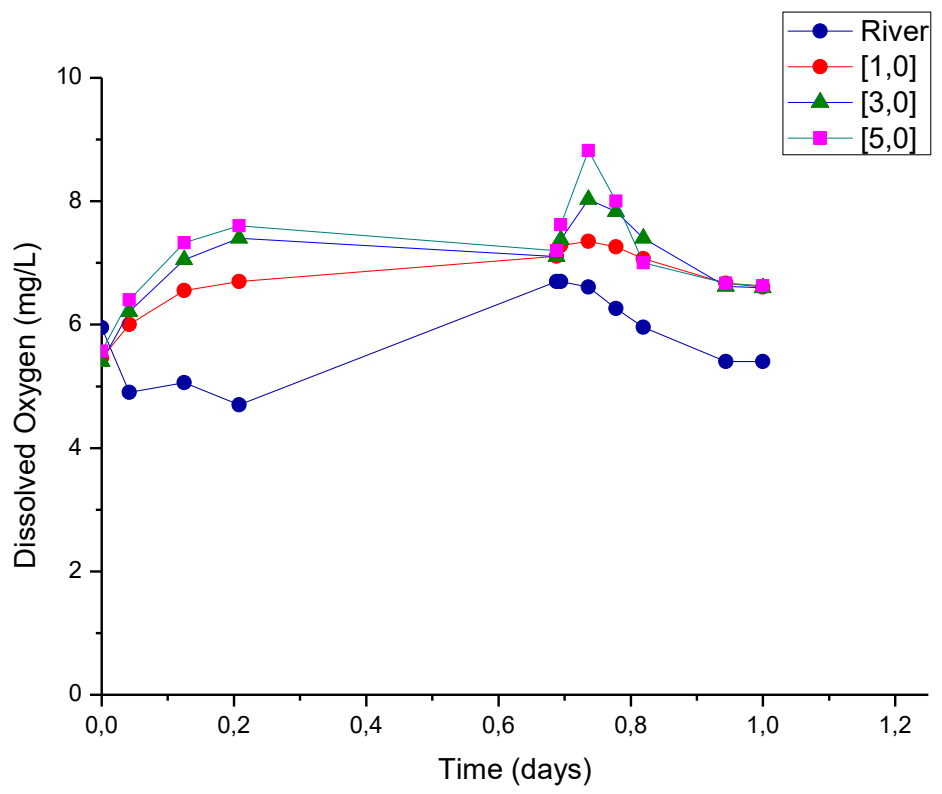

Figura 42 - Concentração de oxigênio dissolvido do rio Rainha com adições de [1,0]; [3,0] e $[5,0]$ mg. $\mathrm{L}^{-1}$ de $\mathrm{H}_{2} \mathrm{O}_{2}$ e amostra sem adição de $\mathrm{H}_{2} \mathrm{O}_{2}$ (river). A precipitação acumulada do dia foi 0,0 mm (RIO - ÁGUAS, 2014). A [COT] foi de 3,0 mg. $\mathrm{L}^{-1}$ e [CIT] 10,0 mg. $\mathrm{L}^{-1} \cdot \mathrm{mg}$

Ao completar o tempo reacional de $24 \mathrm{~h}$, o pH do rio sem adição de $\mathrm{H}_{2} \mathrm{O}_{2}$ apresentou valor de 7,3 enquanto que as amostras com dosagens de peróxido apresentaram valores de $\mathrm{pH}$ 7,4. Ou seja, não houve variação significativa entre os valores de $\mathrm{pH}$ da água do rio após as dosagens de $[1,0]$, $[3,0]$ e $[5,0] \mathrm{mg} . \mathrm{L}^{-1}$ do oxidante.

As Figuras 43 e 44 apresentam respectivamente a curva de depleção do oxigênio dissolvido ao longo de três dias de medição em água do rio Rainha sem adição de peróxido de hidrogênio e a contribuição de OD à água do rio após dosagem de 75,0 mg. $\mathrm{L}^{-1}$ de peróxido. As amostras são características de dia de chuva moderada (3,0 $\mathrm{mm}$ de precipitação). 


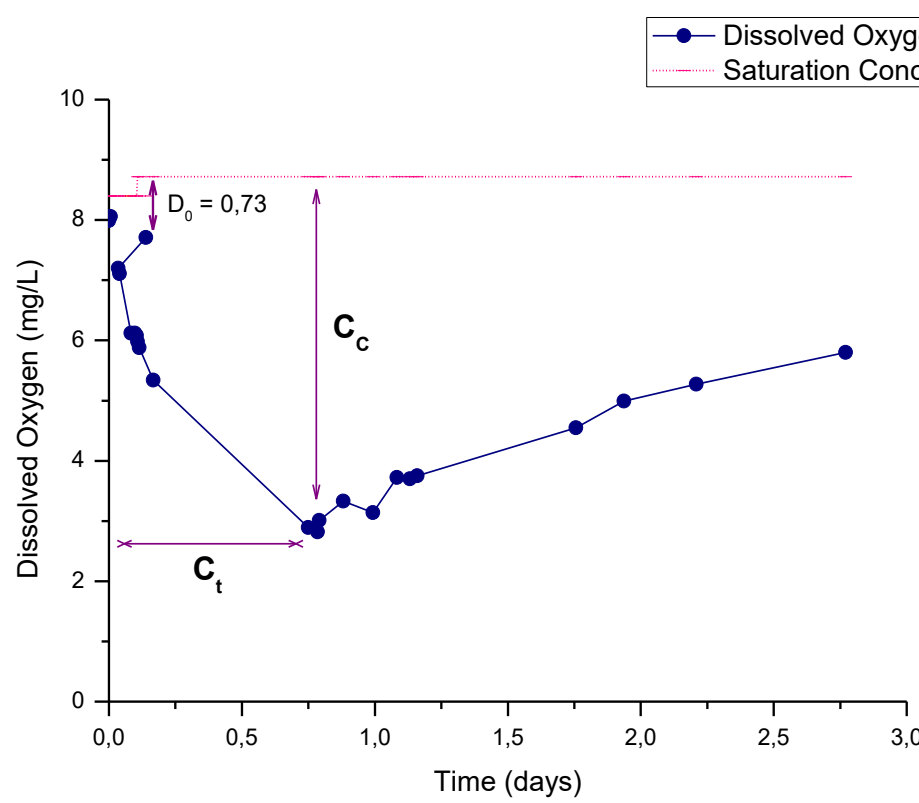

Figura 43 - Concentração de oxigênio dissolvido em água do rio Rainha sem adição de $\mathrm{H}_{2} \mathrm{O}_{2}$ durante três dias de medição. A precipitação acumulada do dia foi $3,0 \mathrm{~mm}$ (RIO ÁGUAS, 2014). Na figura $D_{0}$ representa o déficit inicial de oxigênio dissolvido, Cc representa concentração crítica de oxigênio dissolvido e $C_{t}$ representa tempo crítico. As concentrações de saturação do oxigênio dissolvido foram calculadas de acordo com a tabela EPA, 2012 (tabela de concentração de oxigênio dissolvido em relação à temperatura).

Na Figura 43 é possível observar um déficit inicial de oxigênio $\left(\mathrm{D}_{0}\right)$ de $0,73 \mathrm{mg} . \mathrm{L}^{-1}$ e uma concentração crítica de oxigênio (OD mínimo) de 2,82 mg. $\mathrm{L}^{-1}$, valor este abaixo do preconizado pela legislação (Resolução CONAMA 357/05) para manutenção da vida aquática. Observa-se que apesar da aparente oxigenação apresentada pela água na medição inicial de OD $\left(8,0 \mathrm{mg} \cdot \mathrm{L}^{-1}\right)$, após determinado tempo houve uma rápida depleção dos níveis de oxigênio da água (em menos de um dia), indicando uma considerável concentração de material orgânico presente na amostra. Esta concentração inicial de OD deve-se provavelmente ao local de coleta, a jusante de uma queda d'água dentro do campus da Universidade Católica do Rio de Janeiro (PUC-Rio). Porém, percebe-se que a aeração não foi suficiente para manter os níveis de oxigênio para as próximas horas de medição do OD da água.

Observa-se na figura a seguir, uma significativa contribuição de OD à água do rio após a aplicação do oxidante $\left(75,0 \mathrm{mg} \cdot \mathrm{L}^{-1}\right.$ de $\left.\mathrm{H}_{2} \mathrm{O}_{2}\right)$. 


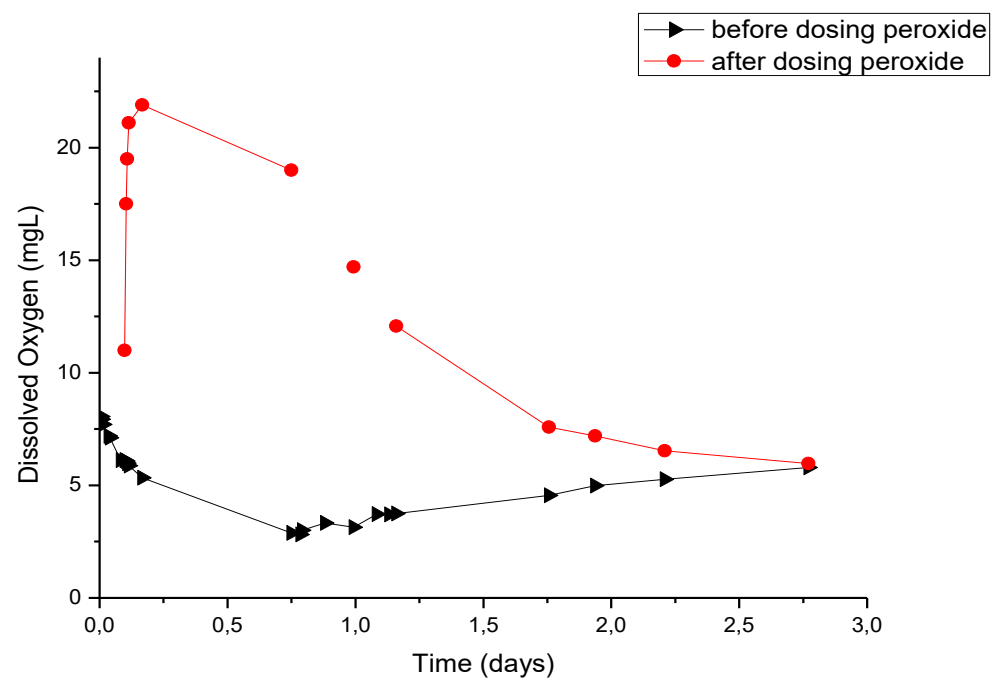

Figura 44 - Concentração de oxigênio dissolvido antes e após dosagem de 75,0 mg.L ${ }^{-1}$ de $\mathrm{H} 2 \mathrm{O} 2 \mathrm{em}$ água do rio Rainha em dia de chuva moderada. A precipitação acumulada do dia foi 3,0 mm (RIO - ÁGUAS, 2014).

Foi realizado um teste em água do rio da Rocinha - RJ (no Canal da Rocinha - não pertencente à Bacia Hidrográfica da LRF). Este rio é diluído com esgoto, cujas concentrações de DBO típicas de esgoto doméstico variam de 100$500 \mathrm{mg} . \mathrm{L}^{-1}$ (HENZE et al., 2008). Logo, foi suposto que tal Rio apresente valores próximos às concentrações médias características de esgotos.

Tal experimento foi realizado para avaliar corpos d'água altamente poluídos com dosagens de peróxido variando de 1 - 20 mg. $\mathrm{L}^{-1}$ como recomendado pela literatura.

A Figura 45 a seguir apresenta os resultados de 1,5 dias de medição do oxigênio dissolvido da água sem adição de peróxido. É possível observar que a curva de depleção de oxigênio apresenta um déficit inicial de OD de 1,94 mg.L ${ }^{-1}$ e concentração crítica (OD mínimo) antes de completar 24 horas de medição de 1,25 mg. $\mathrm{L}^{-1}$ de OD em um tempo crítico de 0,46 dias. Após um dia de medição, uma nova concentração crítica foi observada, com Cc de $0,4 \mathrm{mg} . \mathrm{L}^{-1}$ de OD em 1,5 dias. 


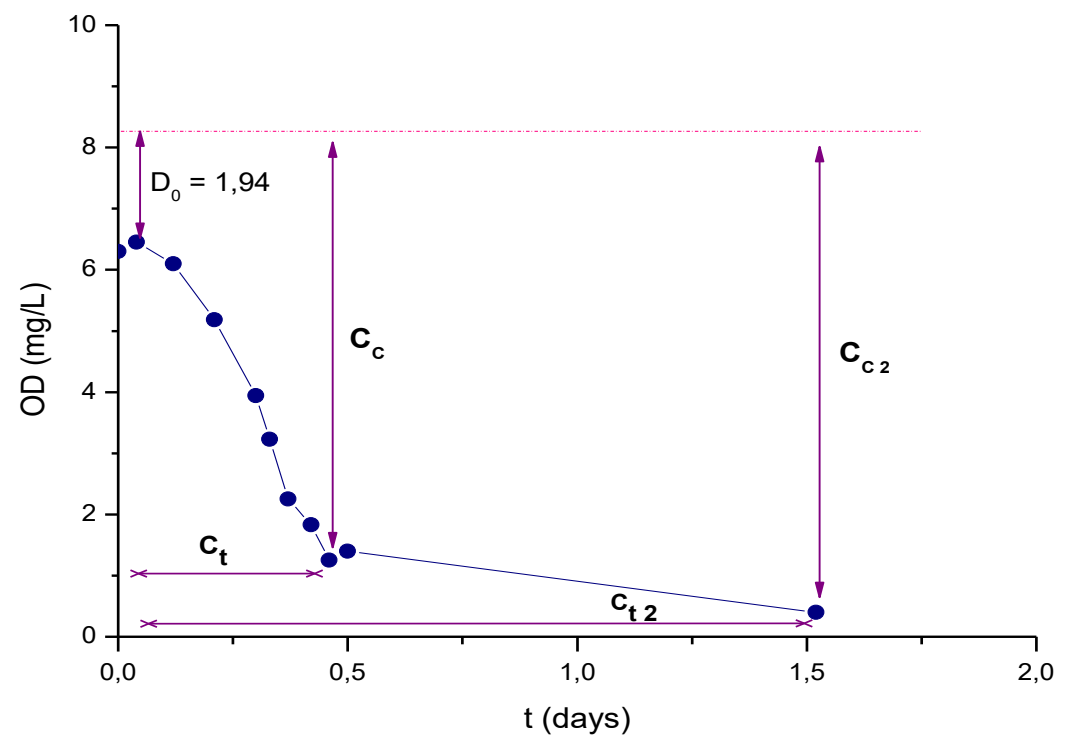

Figura 45 - Concentração de oxigênio dissolvido em água do Canal da Rocinha sem adição de $\mathrm{H}_{2} \mathrm{O}_{2}$ durante um dia e meio de medição. A precipitação acumulada do dia ficou abaixo de 0,5 mm (RIO - ÁGUAS, 2014). Na figura $D_{0}$ representa o déficit inicial de oxigênio dissolvido, Cc representa concentração crítica de oxigênio dissolvido e $C_{t}$ representa tempo crítico. As concentrações de saturação do oxigênio dissolvido (reta pontilhada na figura) foram calculadas de acordo com a tabela EPA, 2012 (tabela de concentração de oxigênio dissolvido em relação à temperatura).

Percebe-se que devido às altas cargas orgânicas presentes neste tipo de corpo hídrico, a capacidade de autodepuração do rio não apresenta um tempo de depuração que permita manter os níveis de OD de acordo com o permitido pela legislação, alcançando assim, em pouco tempo, valores críticos de OD em menos de 12 horas do início do experimento.

Foram então adicionados dosagens de peróxido de hidrogênio variando de 1 a 20,0 mg.L $\mathrm{L}^{-1}$ a fim de observar o processo de depuração acelerada da água do rio por meio dessas dosagens (Figura 46). 


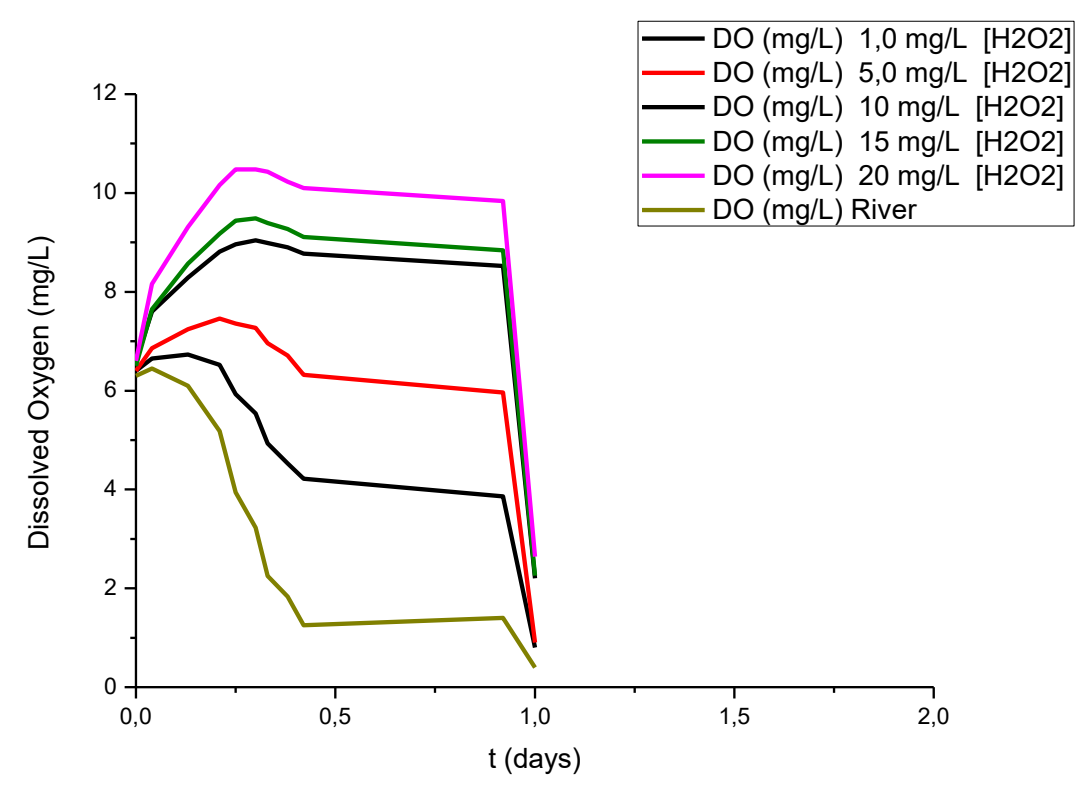

Figura 46 - Concentração de oxigênio dissolvido do Canal da Rocinha com adições de [1,0]; [5,0]; [10,0]; [15,0] e [20,0] mg. $\mathrm{L}^{-1}$ de $\mathrm{H}_{2} \mathrm{O}_{2}$ e amostra sem adição de $\mathrm{H}_{2} \mathrm{O}_{2}$ (river). A precipitação acumulada do dia ficou abaixo de $0,5 \mathrm{~mm}$ (RIO - ÁGUAS, 2014).

$\mathrm{Na}$ Figura 46 percebe-se que após aplicação das dosagens do oxidante houve considerável elevação dos níveis de OD para a água, principalmente para as doses de 10 a 20,0 mg.L $\mathrm{L}^{-1}$. Em 24 horas após dosagem, as concentrações de OD a partir das concentrações dosadas não mantiveram os níveis de OD acima de 5,0 mg. $L^{-1}$. Nota-se a necessidade de constantes reaplicações de dosagens para manutenção do OD permissível para a vida aquática do rio.

O decaimento do peróxido (Figura 47) para as dosagens aplicadas demonstra que em 0,12 dias já havia ocorrido esgotamento do oxidante para a dosagem de 1,0 mg. $\mathrm{L}^{-1}$. Em 0,37 dias ocorreu esgotamento do oxidante para todas as demais dosagens. 


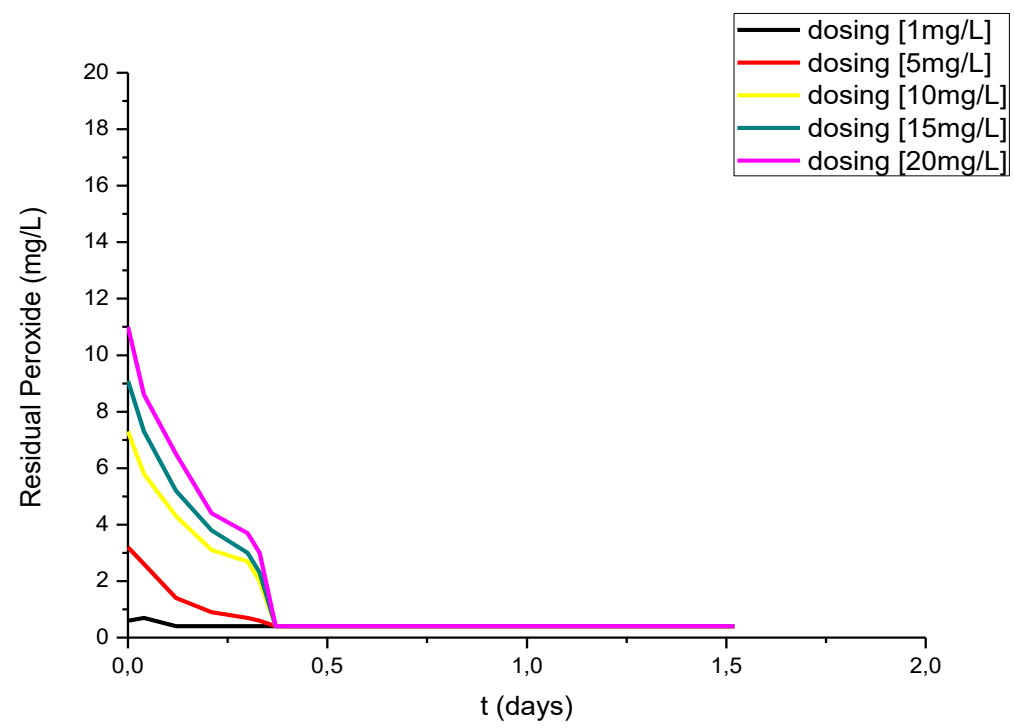

Figura 47 - Concentrações de [1,0]; [5,0]; [10,0], [15,0] e [20,0] mg.L-1 de peróxido residual durante 24 horas. A precipitação acumulada do dia ficou abaixo de $0,5 \mathrm{~mm}$ (RIO - ÁGUAS, 2014).

Com o objetivo de observar a ação do peróxido de hidrogênio na ausência de material orgânico, foi realizado em paralelo uma dosagem de $1,0 \mathrm{mg} . \mathrm{L}^{-1}$ de peróxido em água destilada (teste controle) por 24 horas (Figura 48).

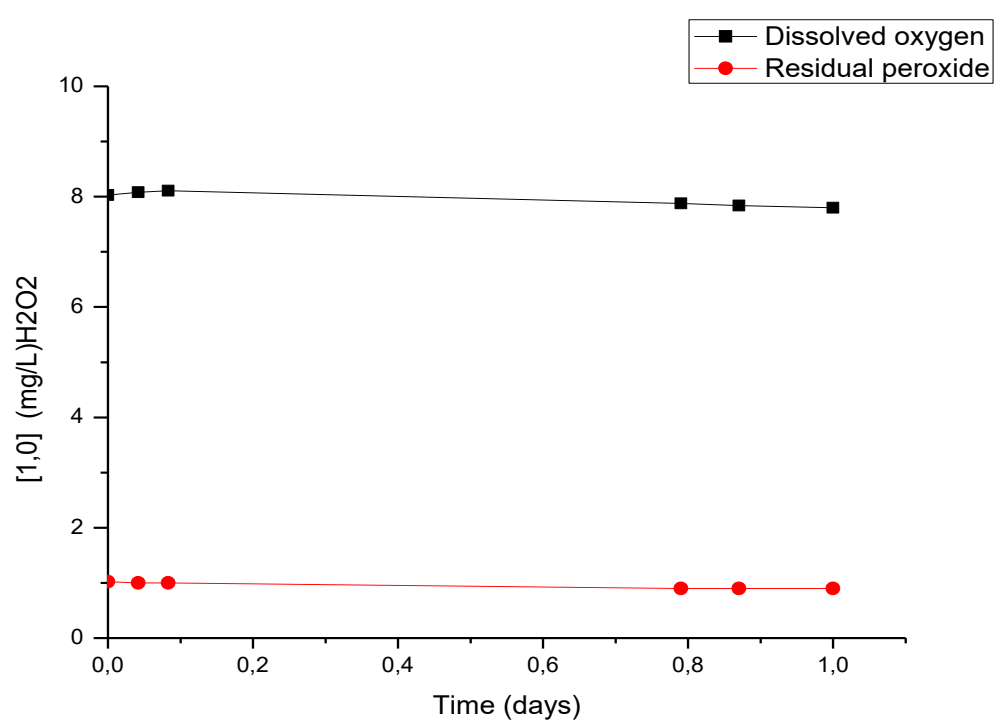

Figura 48 - Concentração de oxigênio dissolvido e peróxido residual aplicado em amostra com água destilada (teste controle). A dosagem aplicada de peróxido foi de $[1,0]$ mg. $\mathrm{L}^{-1}$. 
É possível observar na Figura 48 que na ausência de compostos orgânicos e íons dissolvidos, a decomposição do peróxido e consequente fornecimento de OD à amostra ocorrem a uma taxa muito lenta.

Examinado esses resultados vê-se que sem a intervenção de um processo de depuração acelerada o corpo hídrico pode chegar a uma condição de OD $<5$ mg. $L^{-1}$ e assim ameaçar as condições de sobrevivência da vida aquática sobre o dito rio e eventualmente parte de água da lagoa que possa receber a água desse rio.

Constata-se também que a aplicação de doses de [1,0], [3,0], [5,0] (Figura 42), [75,0] (Figura 44) e [1,0 a 20,0] (Figura 46) mg.L ${ }^{-1}$ de $\mathrm{H}_{2} \mathrm{O}_{2}$ causa uma elevação de OD capaz de evitar a ocorrência de um episódio crítico de baixa OD no corpo hídrico.

\subsection{Experimentos de depuração acelerada}

Os resultados apresentados a seguir são provenientes de testes sobre amostras coletadas durante diferentes eventos de precipitação com diferentes concentrações de material orgânico dissolvido em água dos rios pertencentes à Bacia Hidrográfica da LRF, coletadas no ponto de amostragem 3 do canal da Rua Gal. Garzón.

As figuras correspondem ao comportamento da curva de oxigênio dissolvido antes e após aplicação de diferentes dosagens de peróxido de hidrogênio e o decaimento de sua concentração ao longo do tempo de reação de 24 horas.

A cinética de decaimento do peróxido foi observada após adição de diferentes dosagens. Porém, há uma dificuldade na formulação de modelos cinéticos, pois a matéria orgânica presente em águas naturais impactadas por lançamento de esgoto é muito complexa para ser determinada. Na suposição que essa matéria orgânica seja pouco atacada (oxidada diretamente) pelo peróxido durante os instantes iniciais da depuração, procedeu-se a uma simplificação de que a concentração da mesma possa ser considerada na equação cinética como constante, não 
possibilitando, portanto, determinar com precisão a ordem da reação de cada teste, já que a composição da matéria orgânica é variável e característica de cada experimento.

Segundo REINA et al. (2012), o modelo de pseudo-primeira ordem é uma descrição cinética comum, suficiente para explicar o decaimento do composto de origem. Além do que, é conhecido que a cinética de auto-decomposição do $\mathrm{H}_{2} \mathrm{O}_{2}$ em soluções aquosas segue um modelo de primeira ordem, onde a constante cinética além de depender da temperatura, depende da atividade de catalisadores presentes (íons de metais tais como de ferro, manganês e cobre; catalase; substâncias sólidas diversas em suspensão; etc.).

Então, para todas as experiências realizadas no presente trabalho, a taxa inicial de decaimento do $\mathrm{H}_{2} \mathrm{O}_{2}$ foi descrita por uma lei cinética de pseudo-primeira ordem em relação ao próprio reagente $\mathrm{H}_{2} \mathrm{O}_{2}$.

Para a seguinte relação:

$$
\ln \left(\left[\mathrm{H}_{2} \mathrm{O}_{2}\right] /\left[\mathrm{H}_{2} \mathrm{O}_{2}\right]_{0}\right)=-\mathbf{k}_{\text {obs }} \cdot \mathbf{t}
$$

Onde: $\mathrm{k}_{\mathrm{obs}}$ é a pseudo constante de velocidade aparente para a taxa de reação de decaimento do peróxido de hidrogênio obtida em condições de $\left[\mathrm{H}_{2} \mathrm{O}_{2}\right]$ fixada.

\section{Experimento 1 (Coleta 1$)$}

As Figuras 49, 50 e 51 apresentam resultados de testes sobre amostras coletadas no mês de agosto (2014) em dia de precipitação de $0,8 \mathrm{~mm}$ e DBO de 2,0 $\pm 0,4 \mathrm{mg} \cdot \mathrm{L}^{-1}$. Observa-se que apesar da ocorrência de precipitação, as amostras apresentaram boas condições de oxigenação, com um déficit inicial de oxigênio $\left(\mathrm{D}_{0}\right)$ de $1,5 \mathrm{mg} \cdot \mathrm{L}^{-1}$.

Para observar mais detalhadamente o comportamento da curva de OD do rio após o evento de precipitação, mediu-se durante dois dias o oxigênio dissolvido da água sem a adição de $\mathrm{H}_{2} \mathrm{O}_{2}$ (Figura 49). 


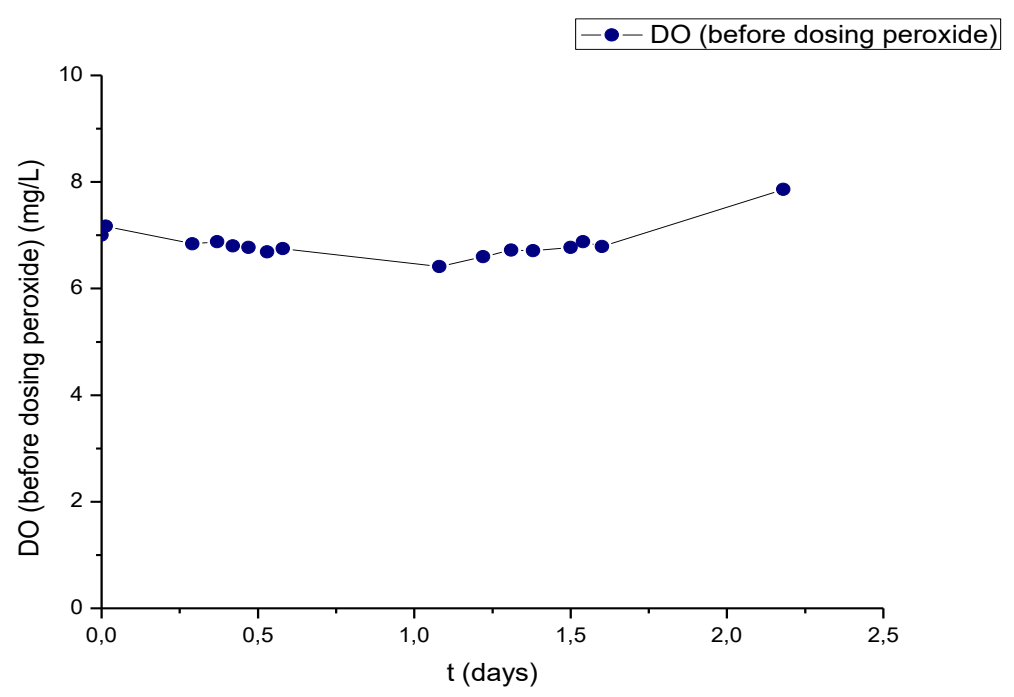

Figura 49 - Concentração de oxigênio dissolvido em água de rio sem adição de $\mathrm{H}_{2} \mathrm{O}_{2}$ durante dois dias de medição. A precipitação acumulada do dia foi $0,8 \mathrm{~mm}$ (RIO ÁGUAS, 2014). A DBO5 (no Ponto 3) foi de 2,0 \pm 0,4 mg.L-1.

Ao observar a curva de oxigênio dissolvido durante dois dias, nota-se inicialmente, no primeiro dia, uma pequena redução seguida de um aumento da concentração de $\mathrm{OD}$, fato este característico da autodepuração natural dos corpos hídricos, onde a elevação dos níveis de OD ocorre em parte após uma maior estabilização da matéria orgânica presente no corpo hídrico, apresentando menor demanda de oxigênio para degradação da matéria orgânica. O OD mínimo apresentado pela água foi de $6,4 \mathrm{mg} . \mathrm{L}^{-1}$, mostrando que a concentração mínima não ficou abaixo do limite estabelecido pela Resolução 357/05 do CONAMA, onde para os rios de classe 2, não pode ser inferior a 5,0 mg. $\mathrm{L}^{-1}$.

Para verificar a contribuição do peróxido de hidrogênio na elevação do oxigênio dissolvido do rio durante 24 horas, adicionou-se $[12,0]{ }_{\mathrm{H} 2 \mathrm{O} 2} \mathrm{mg} . \mathrm{L}^{-1}$. 


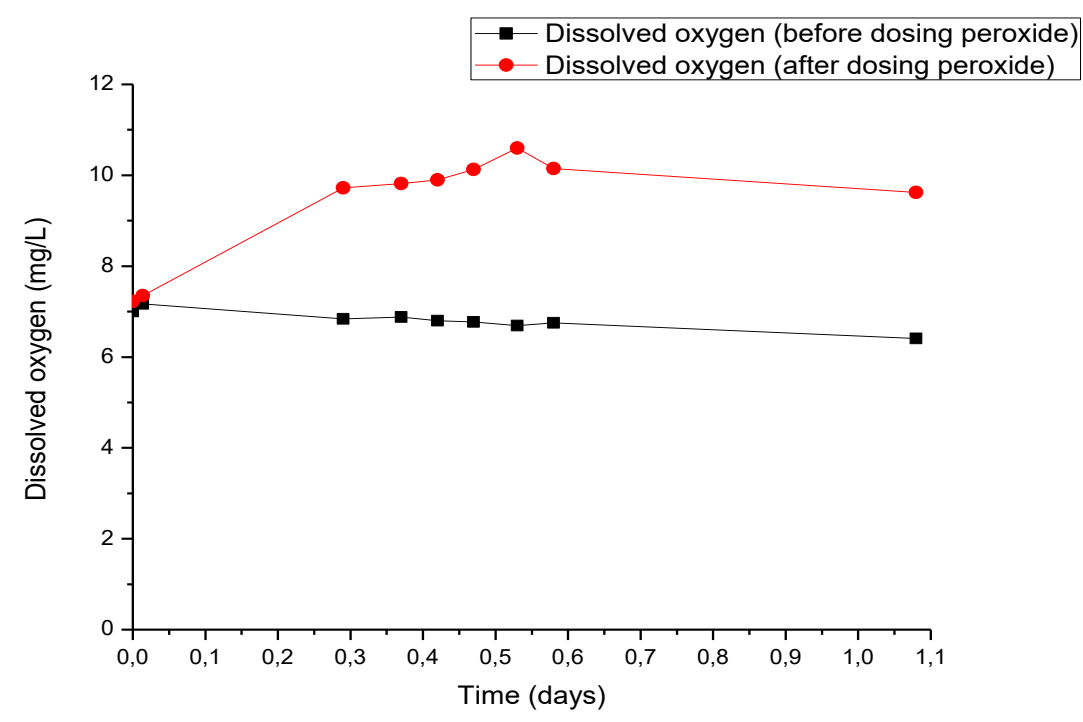

Figura 50 - Concentração de oxigênio dissolvido do rio em amostra com adição de 12,0 mg. $L^{-1}$ de $\mathrm{H}_{2} \mathrm{O}_{2}$ e amostra sem adição de $\mathrm{H}_{2} \mathrm{O}_{2}$. A precipitação acumulada do dia foi 0,8 mm (RIO - ÁGUAS, 2014). A DBO5 (no Ponto 3) foi de 2,0 \pm 0,4 mg.L-1.

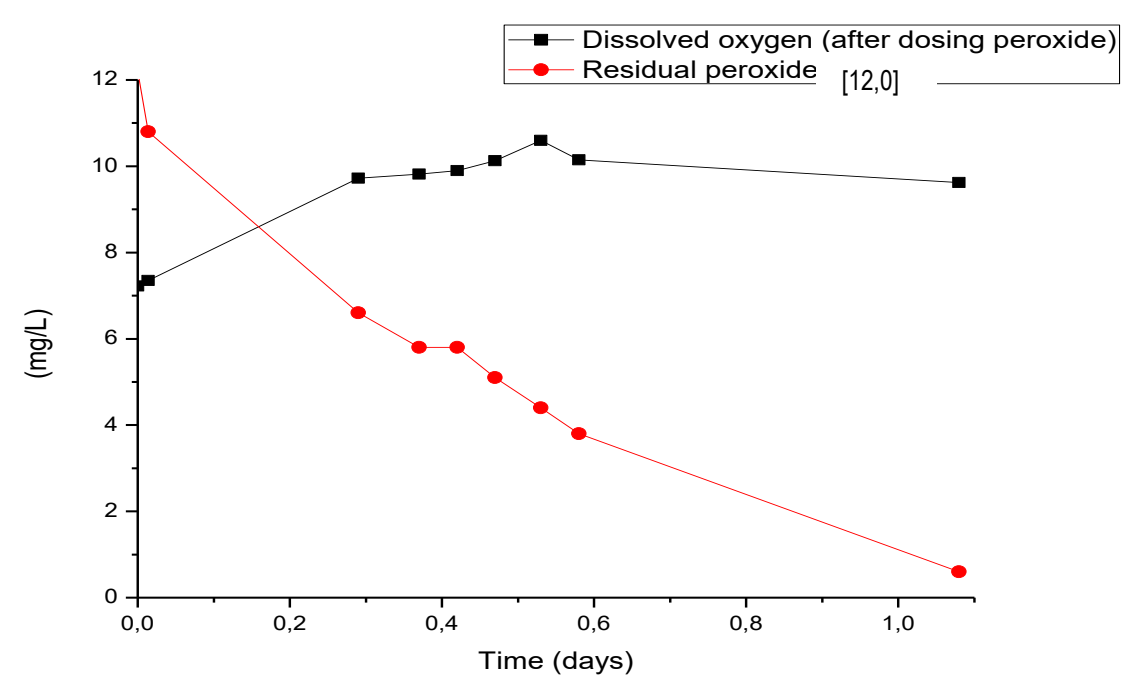

Figura 51 - Concentração de oxigênio dissolvido e peróxido residual após adição de 12,0 $\mathrm{mg} \cdot \mathrm{L}^{-1}$. A precipitação acumulada foi $0,8 \mathrm{~mm}$ (RIO - ÁGUAS, 2014). A DBO5 (no Ponto 3) foi de 2,0 $\pm 0,4 \mathrm{mg} \cdot \mathrm{L}^{-1}$.

Observa-se na Figura 50 que a curva de OD após adição do peróxido teve um aumento significativo, cujo fornecimento teórico de OD para a amostra foi de 5,6 mg. $\mathrm{L}^{-1}$, porém, a concentração máxima de OD observada foi de 10,6 $\mathrm{mg} . \mathrm{L}^{-1}$ (em 0,5 dias), presumindo-se assim haver ocorrido uma perda de $2 \mathrm{mg} . \mathrm{L}^{-1}$ de OD para a atmosfera e/ou por consumo na oxidação de matéria orgânica 
dissolvida. Ao medir o peróxido residual (Figura 51), percebe-se que à medida que a [OD] aumenta, a concentração de peróxido diminui, evidenciando o fornecimento de oxigênio para amostra do rio e/ou consumo na oxidação de alguma matéria orgânica dissolvida. Porém, a concentração de $\mathrm{H}_{2} \mathrm{O}_{2}$ obtida pela dosagem aplicada neste teste não atendeu ao limite máximo estabelecido pela ENVIRONMENT AGENCY (1998), onde durante as 12 horas (0,5 dias) iniciais é recomendado que ocorra um decaimento da $\left[\mathrm{H}_{2} \mathrm{O}_{2}\right]$ para valores menores que 1,0 mg. $\mathrm{L}^{-1}$ e para menores concentrações ao término de 24 horas, para manutenção da vida aquática.

A Figura 52 a seguir apresenta resultados da modelagem cinética de pseudo - primeira ordem da reação para a dosagem de $12,0 \mathrm{mg} \cdot \mathrm{L}^{-1}$ de $\mathrm{H}_{2} \mathrm{O}_{2}$.

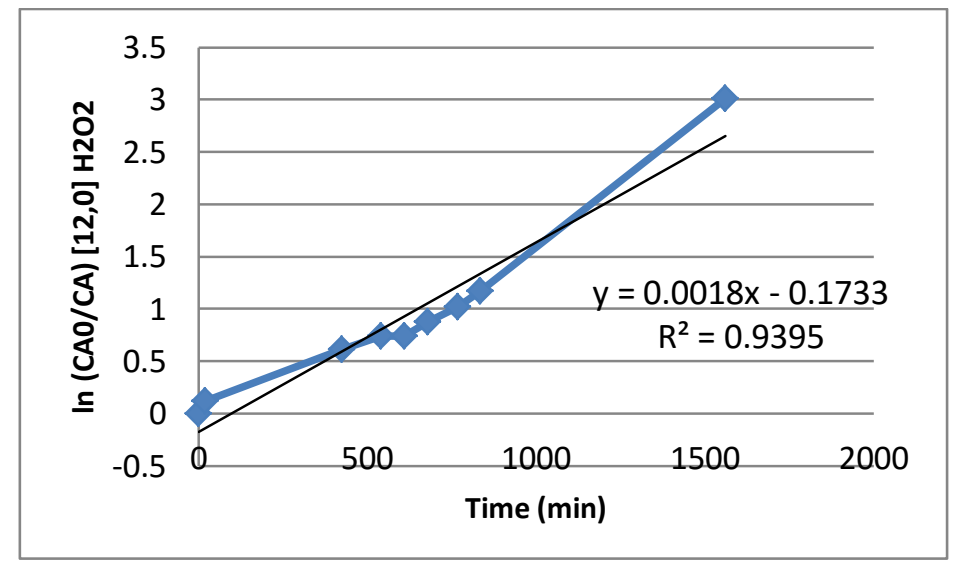

Figura 52 - Pseudo- primeira ordem de reação cinética para a dosagem de $12,0 \mathrm{mg} \cdot \mathrm{L}^{-1}$ de $\mathrm{H}_{2} \mathrm{O}_{2}$ em água de rio contendo $2,0 \mathrm{mg} \cdot \mathrm{L}^{-1}$ de $\mathrm{DBO}$. A precipitação acumulada foi 0,8 mm (RIO - ÁGUAS, 2014).

\section{Experimento 2 (Coleta 2)}

Os resultados apresentados nas Figuras 53, 54 e 55, são provenientes de testes sobre amostras coletadas no mês de setembro (2014) em dia de precipitação abaixo de $0,5 \mathrm{~mm}$ de chuva e DBO de $1,4 \pm 0,5 \mathrm{mg} \cdot \mathrm{L}^{-1}$. Durante a coleta das amostras, ocorria deságue dos rios confluídos Macacos e Cabeça para a Lagoa Rodrigo de Freitas através de abertura da comporta do Canal de confluência dos mesmos (ponto de amostragem 3). 
Para observar com mais detalhes a variação da [OD] do rio após o evento de precipitação, mediu-se durante dois dias o oxigênio dissolvido da água sem a adição de $\mathrm{H}_{2} \mathrm{O}_{2}$ (Figura 53).

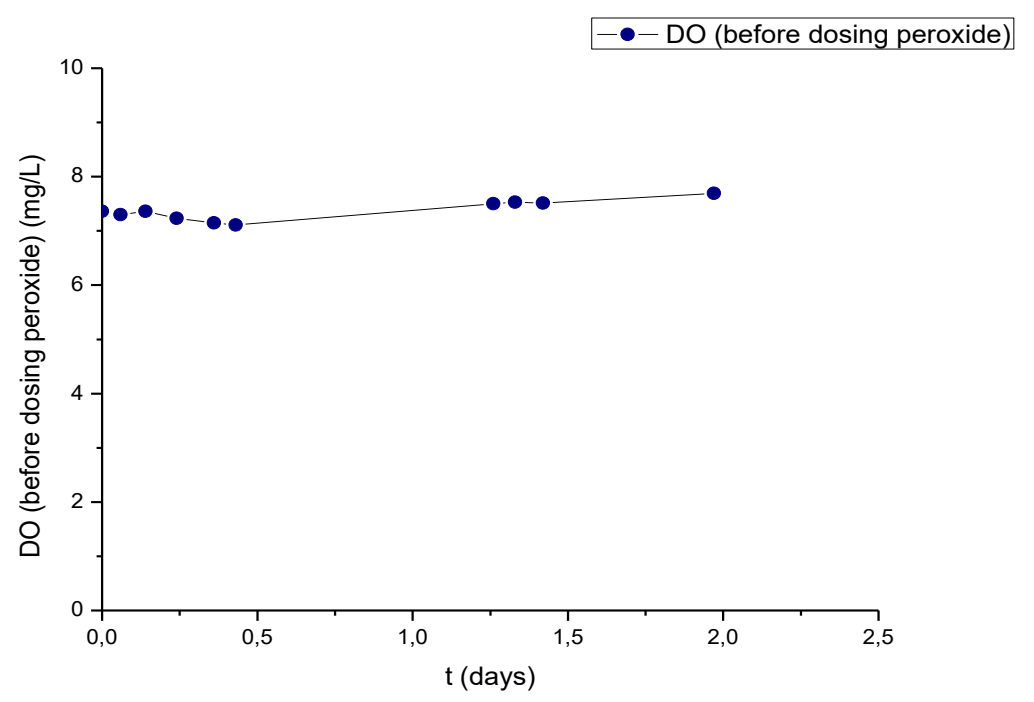

Figura 53 - Concentração de oxigênio dissolvido em água de rio sem adição de $\mathrm{H}_{2} \mathrm{O}_{2}$ durante dois dias de medição. A precipitação acumulada ficou abaixo de $0,5 \mathrm{~mm}$ (RIO ÁGUAS, 2014). A $\mathrm{DBO}_{5}$ (no Ponto 3) foi de 1,4 \pm 0,5 mg.L-1.

A concentração de OD na amostra do rio sem adição de peróxido de hidrogênio (Figura 53) apresentou pouca variação, baixando de $7,4 \mathrm{mg} . \mathrm{L}^{-1}$ para o OD mínimo de 7,1 mg. $\mathrm{L}^{-1}$ em 0,4 dias de monitoramento; provavelmente devido à baixa precipitação de chuva ocorrida no dia da coleta, o que pode ter influenciado a baixa concentração de material orgânico (DBO 1,4 $\pm 0,5 \mathrm{mg} \cdot \mathrm{L}^{-1}$ ) carreado para as águas dos rios em estudo. Não foi observado durante esta coleta lançamento de esgotos no canal na área de amostragem.

Para verificar a contribuição do peróxido de hidrogênio na elevação do oxigênio dissolvido do rio durante 24 horas, foram adicionadas as seguintes dosagens de peróxido: [1,5], [5,0], [11] e [20,0] mg.L.-1 


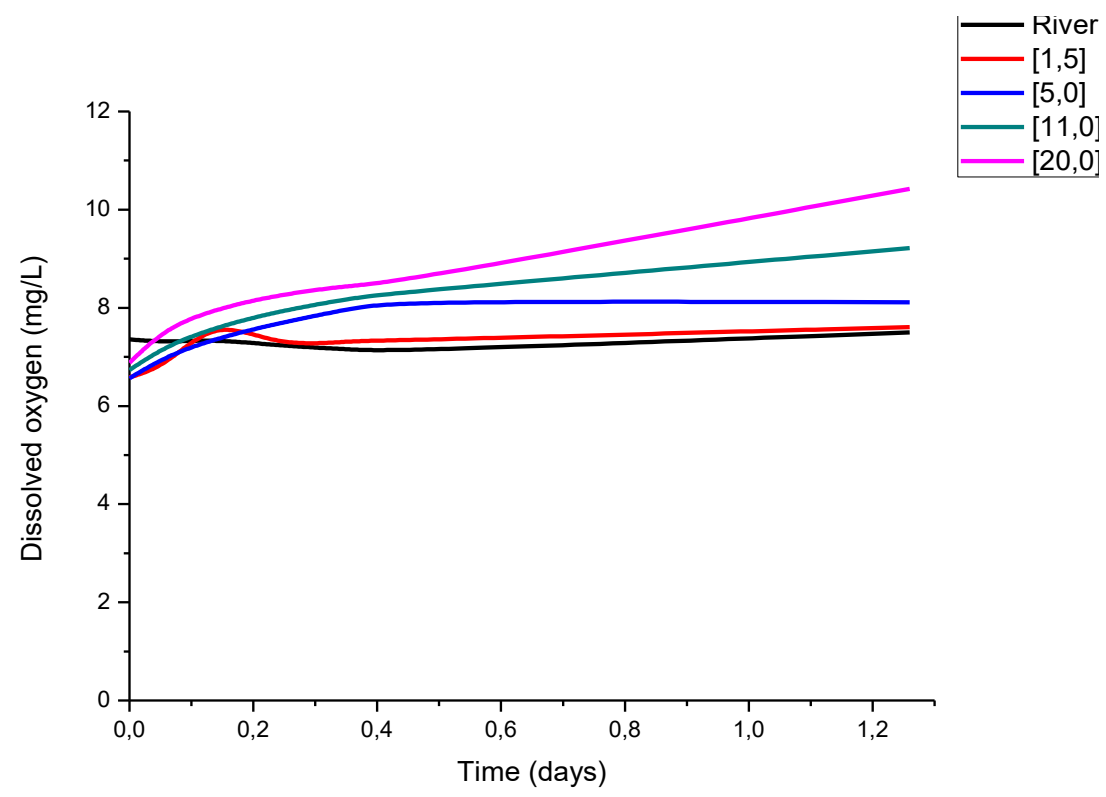

Figura 54 - Concentração de oxigênio dissolvido das amostras de água do rio com adições de [1,5]; [5,0]; [11,0] e [20,0] mg. $\mathrm{L}^{-1}$ de $\mathrm{H}_{2} \mathrm{O}_{2}$ e amostra sem adição de $\mathrm{H}_{2} \mathrm{O}_{2}$ (river). A precipitação acumulada ficou abaixo de $0,5 \mathrm{~mm}$ (RIO - ÁGUAS, 2014). A DBO (no Ponto 3) foi de $1,4 \pm 0,5 \mathrm{mg} \cdot \mathrm{L}^{-1}$.

Os resultados apresentaram uma dependência da elevação de OD com as concentrações iniciais de $\mathrm{H}_{2} \mathrm{O}_{2}$ dosadas. Ao observar as concentrações máximas de oxigênio após 24 hs, percebe-se principalmente nas dosagens de [11,0] e [20,0] mg. $\mathrm{L}^{-1}$ de $\mathrm{H}_{2} \mathrm{O}_{2}$ menores concentrações de oxigênio do que realmente o oxidante forneceu, sendo este resultado provavelmente em grande parte referente à perda de OD para a atmosfera após determinada concentração na água. Para REINA et al. (2012), altas taxas de dosagem de peróxido levam à formação de reagente em excesso e à alta produção de oxigênio. Esta concentração de oxigênio pode então, apresentar-se acima da concentração de saturação (concentração de equilíbrio) da água dependendo da temperatura, o que ocasiona em perdas de parte do oxigênio que foi fornecido. É importante ressaltar que a concentração de saturação de OD do rio no momento da coleta foi de $8,4 \mathrm{mg} . \mathrm{L}^{-1}$ (valor obtido pela tabela de concentração máxima de oxigênio dissolvido de acordo com a variação da temperatura - EPA, 2014). Para a dosagem de [11,0] e [20,0], observou-se perdas em torno de 1,0 e $6,0 \mathrm{mg} . \mathrm{L}^{-1}$ respectivamente. As dosagens de $[1,5],[5,0] \mathrm{mg} . \mathrm{L}^{-1}$ não apresentaram perdas significativas. 


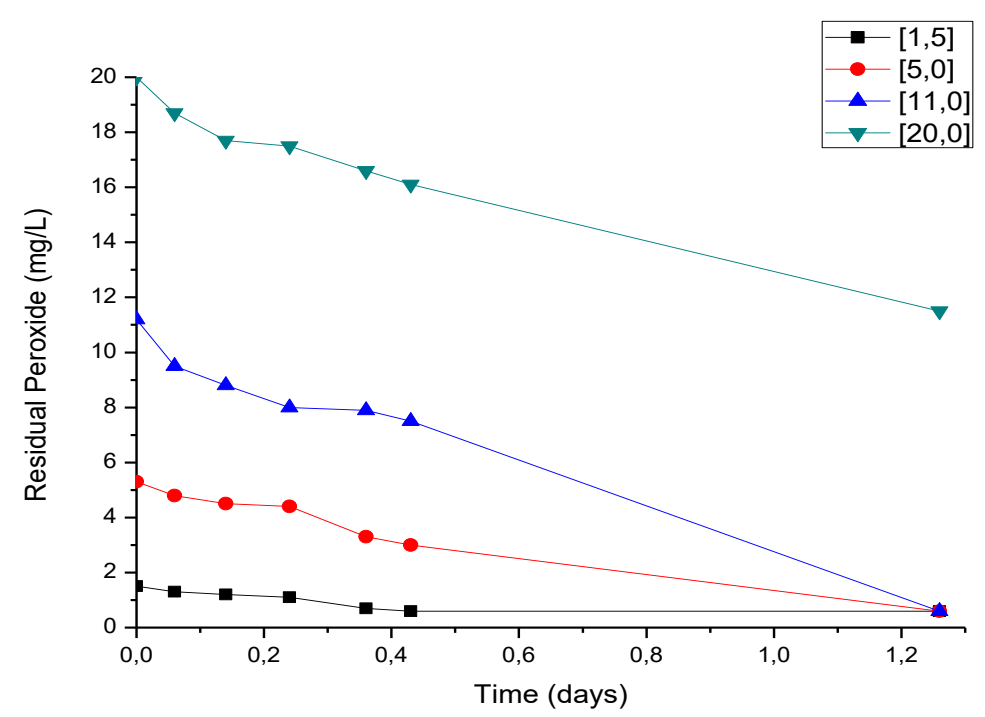

Figura 55 - Concentrações de $[1,5] ;[5,0] ;[11,0]$ e $[20,0]$ mg. $\mathrm{L}^{-1}$ de peróxido residual durante 24 horas. A precipitação acumulada ficou abaixo de $0,5 \mathrm{~mm}$ (RIO - ÁGUAS, 2014). $\mathrm{A} \mathrm{DBO}_{5}$ (no ponto 3 ) foi de $1,4 \pm 0,5 \mathrm{mg} \cdot \mathrm{L}^{-1}$.

A Tabela 8 apresenta os valores da velocidade inicial de decaimento do peróxido obtida em 85 minutos (0,06 dias) após início da reação, mostrando que a partir de uma dosagem de $11,0 \mathrm{mg} . \mathrm{L}^{-1}$ não há alteração significativa na velocidade da reação. Através das constantes cinéticas (Figura 57) de cada dosagem de peróxido aplicada também foi possível observar que doses maiores que $11,0 \mathrm{mg} . \mathrm{L}^{-1}$ não causam aumento no desempenho do processo.

Tabela 8- Velocidade inicial de decaimento das concentrações de peróxido em 85 minutos $(0,06$ dias $)$ de reação.

\begin{tabular}{|c|c|}
\hline $\begin{array}{c}{\left[\mathbf{H}_{2} \mathbf{O}_{2}\right]_{\mathbf{0}}} \\
\left(\mathbf{m g .}^{-\mathbf{1}}\right)\end{array}$ & $\begin{array}{c}\text { Velocidade Inicial } \\
\left(\mathbf{V}_{\mathbf{0}}\right) \\
\left(\mathbf{m i n} \mathbf{}^{-\mathbf{1}}\right)\end{array}$ \\
\hline 1,5 & 0,0023 \\
\hline 5,0 & 0,0059 \\
\hline 11,0 & 0,02 \\
\hline 20,0 & 0,0153 \\
\hline
\end{tabular}

Plotando $\log \left(-d \frac{[H 2 O 2]}{d t}\right)$ em função de $\log \left[\mathrm{H}_{2} \mathrm{O}_{2}\right]$, obtêm-se os valores de $\alpha$ e $\mathrm{K}_{\mathrm{H} 2 \mathrm{O} 2 \mathrm{ap} .}$ A ordem aparente da reação $(\alpha)$ é apresentada na Figura 56. 


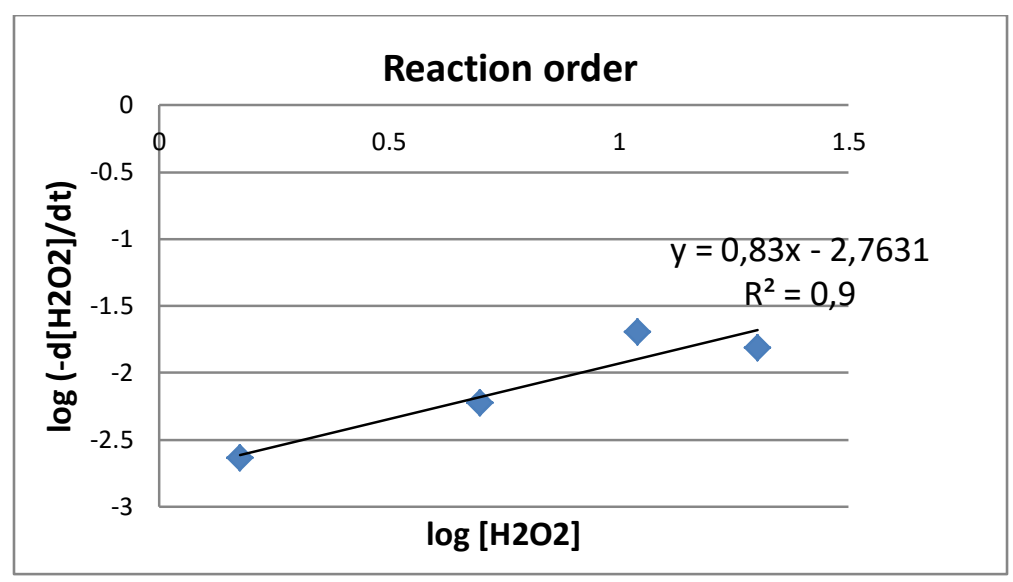

Figura 56 - Ordem aparente de reação de decaimento do $\mathrm{H} 2 \mathrm{O} 2$ de acordo com a velocidade inicial das dosagens de [1,5], [5,0], $[11,0]$ e $[20,0] \mathrm{mg} . \mathrm{L}-1$ de H2O2 em água de rio contendo $1,4 \mathrm{mg} . \mathrm{L}-1$ de DBO. A precipitação acumulada ficou abaixo $0,5 \mathrm{~mm}$ (RIO - ÁGUAS, 2014).
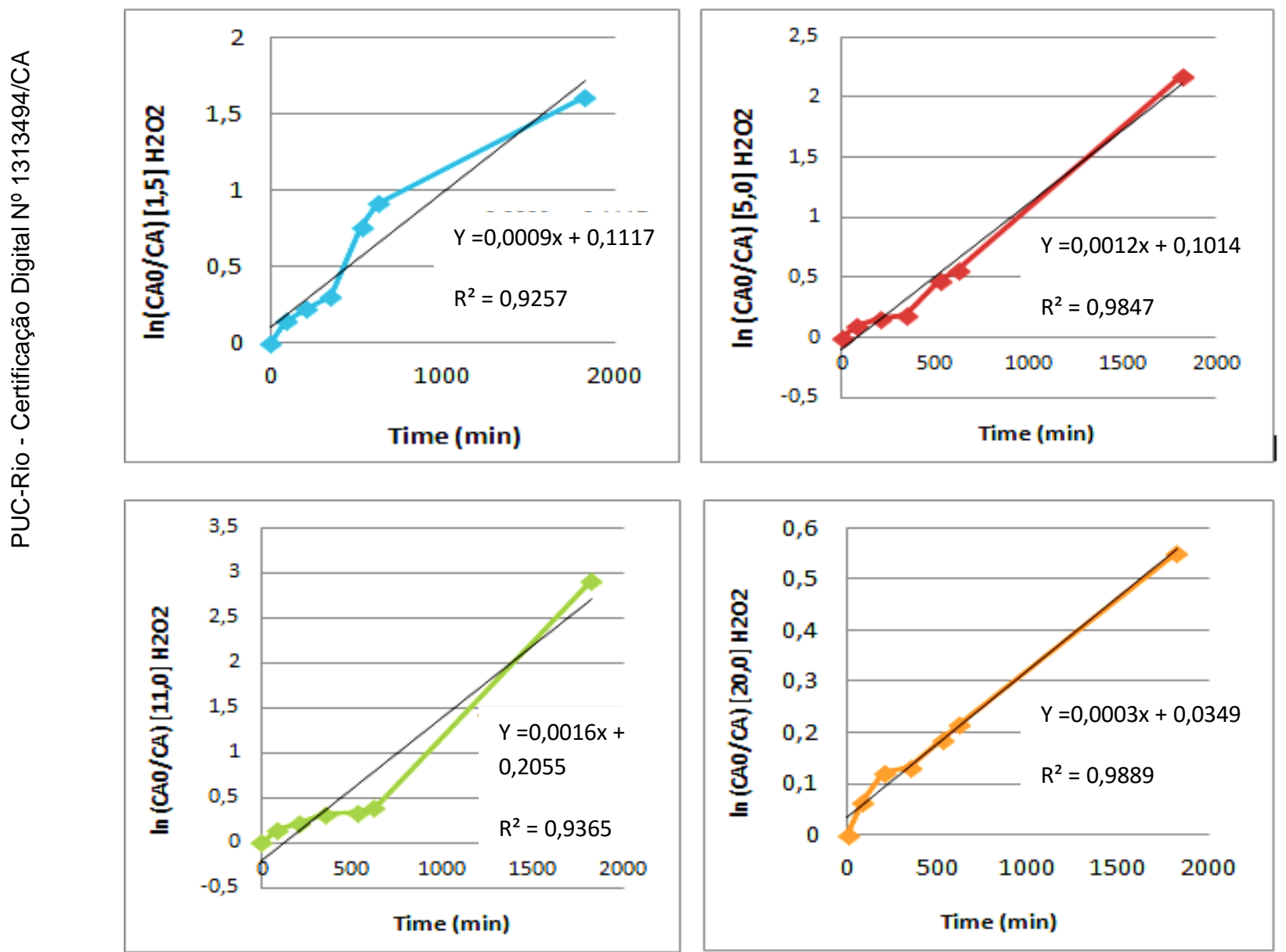

Figura 57 - Constantes cinéticas de pseudo-primeira ordem de decaimento do peróxido para as dosagens de $[1,5],[5,0]$, $[11,0]$ e $[20,0] \mathrm{mg}^{-\mathrm{L}^{-1}}$ de $\mathrm{H}_{2} \mathrm{O}_{2}$ em água de rio contendo $1,4 \mathrm{mg} \cdot \mathrm{L}^{-1}$ de $\mathrm{DBO}_{5}$. A precipitação acumulada do dia ficou abaixo de $0,5 \mathrm{~mm}$ (RIO ÁGUAS, 2014). 
A reta de linearização de uma equação cinética de segunda ordem também foi testada para todos os experimentos deste estudo, porém, os valores de $\mathrm{R}^{2}$ obtidos foram inferiores em comparação aos valores encontrados para as reações de pseudo primeira-ordem.

Apesar da contribuição de oxigênio dissolvido das amostras de [5,0]; $[11,0]$ e $[20,0] \mathrm{mg} \cdot \mathrm{L}^{-1}$, as concentrações de peróxido não apresentaram valores inferiores ao estabelecido pela Environment Agency (1998), onde durante as 12 horas $(0,5$ dias $)$ iniciais é recomendado acontecer um decaimento da $\left[\mathrm{H}_{2} \mathrm{O}_{2}\right]$ para valores menores que $1,0 \mathrm{mg} . \mathrm{L}^{-1}$ ao completar 12 horas de reação e para menores concentrações ao término de 24 horas, para manutenção da vida aquática.

Apenas a dosagem de $1,5 \mathrm{mg} . \mathrm{L}^{-1}$ de $\mathrm{H}_{2} \mathrm{O}_{2}$ apresentou um decaimento no tempo esperado, ocorrendo durante as seguintes 12 horas de reação uma concentração residual de $0,6 \mathrm{mg} . \mathrm{L}^{-1}$ de $\mathrm{H}_{2} \mathrm{O}_{2}$.

Pode-se notar que devido às baixas concentrações de DBO nas amostras dos testes discutidos até agora (realizados nos meses de agosto e setembro), não houve necessidade de reaplicação do oxidante, pois ocorreu uma suplementação de OD progressiva para as amostras a partir das dosagens de peróxido aplicadas.

Segundo a ENVIRONMENT AGENCY (1998), se a matéria orgânica estiver presente em baixas concentrações no corpo hídrico, o $\mathrm{H}_{2} \mathrm{O}_{2}$ não irá se decompor ou irá se decompor a uma taxa lenta, já que haverá baixa concentração de substrato para o oxidante reagir. Outro fator que pode estar diretamente associado à velocidade de decaimento do peróxido em relação à concentração de matéria orgânica da água é a enzima catalase. Esta enzima é encontrada em quase todas as células animais, de plantas e de microorganismos. Sua principal característica é a intensa atividade catalítica apresentada na decomposição do peróxido. O peróxido de hidrogênio é um subproduto da respiração celular (sendo danoso às células dependendo da concentração), as células dos organismos produzem então a catalase capaz de catalisar a decomposição do $\mathrm{H}_{2} \mathrm{O}_{2}$ em água e oxigênio.

$$
2 \mathrm{H}_{2} \mathrm{O}_{2} \underset{\text { catalase }}{\rightarrow} \mathrm{O}_{2}+2 \mathrm{H}_{2} \mathrm{O}
$$


Então, este tipo de enzima pode estar presente e atuante em meios como o deste estudo, catalisando somente a decomposição do peróxido, sem que o mesmo chegue a oxidar a matéria orgânica. Segundo GEORGE (1947), a catalase pode existir em duas formas: uma forma mais ativa, presente durante a rápida evolução inicial da concentração de oxigênio, a qual muda em poucos minutos para uma forma menos ativa, responsável pela evolução mais lenta e estável da formação de oxigênio.

A decomposição do peróxido também pode ser afetada pelos íons presentes na água (ex. Fe, $\mathrm{Mn}, \mathrm{Cu}$ ), apresentando efeito catalítico.

As baixas taxas de precipitação de chuva nos dias de coleta das amostras devem ter contribuído para as menores concentrações de matéria orgânica encontradas, já que o volume de escoamento (run-off) não foi elevado suficientemente para carrear significativas concentrações de poluentes para o corpo hídrico, além de não ter sido observado no momento das coletas lançamento de esgotos sobre o canal de estudo.

Os valores do pH medido após o tempo reacional de 24 hs variaram de 7,4 a 7,5 para as doses de peróxido aplicadas. O rio sem adição de peróxido apresentou pH inicial de 7,3 (Tabela A4-1, Apêndice 4).

\section{Experimento 3 (Coleta 3$)$}

As Figuras 58 e 59 apresentam resultados de amostras coletadas sob precipitação abaixo de 0,5 mm e DBO de 24,0 mg. $\mathrm{L}^{-1}$. Observa-se que apesar da baixa precipitação no dia da amostragem, a concentração de DBO estava acima do limite estabelecido pela Resolução 357/05 do CONAMA, onde para os rios de classe 2, o valor da mesma não pode ser superior a 5,0 mg. $\mathrm{L}^{-1}$. No momento da coleta observava-se visualmente contribuição de esgoto indevido proveniente do Canal do Jockey, sendo este provavelmente, o fator causador da alta concentração de DBO. 
Para verificar o efeito da adição de peróxido no fornecimento de OD nas amostras, aplicou- se as seguintes concentrações: [1,0]; [5,0]; [15,0] e [20,0] $\operatorname{mg} . \mathrm{L}^{-1}$.

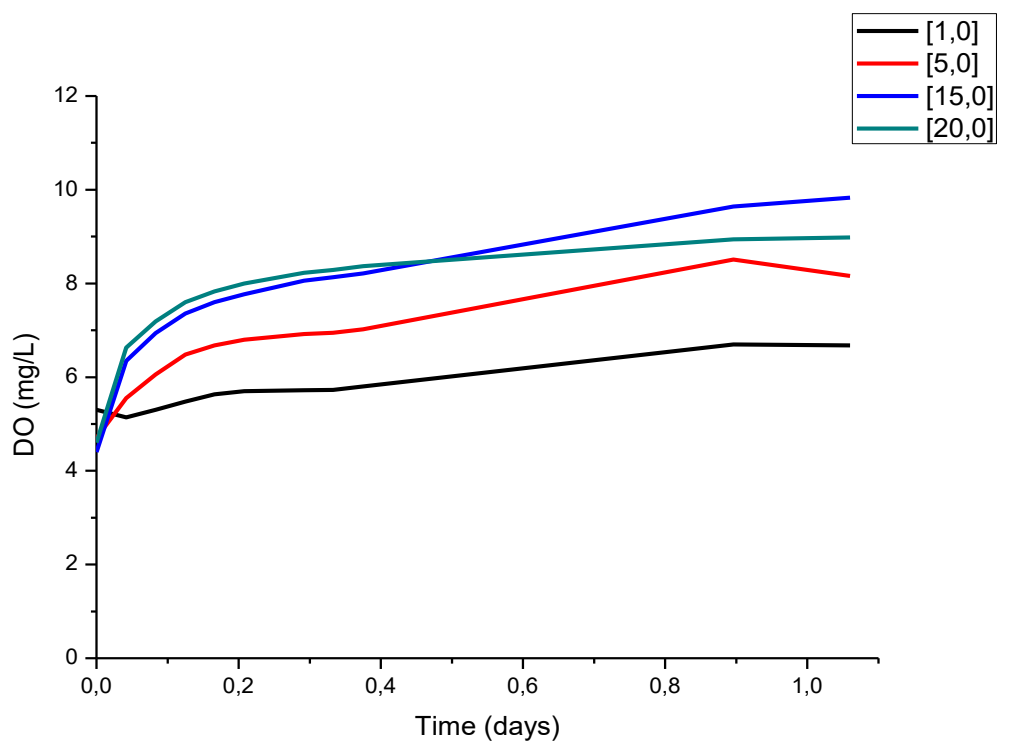

Figura 58 - Concentração de oxigênio dissolvido em amostras de água do rio com adições de [1,0]; [5,0]; $[15,0]$ e $[20,0] \mathrm{mg}^{-\mathrm{L}^{-1}}$ de $\mathrm{H}_{2} \mathrm{O}_{2}$. Em 0,37 dias houve nova adição de peróxido para as concentrações de $[1,0]$ e $[5,0] \mathrm{mg} \cdot \mathrm{L}^{-1}$. A precipitação acumulada a ficou abaixo de 0,5 mm (RIO - ÁGUAS, 2014). A DBO 5 (no Ponto 3) foi de 24,0 \pm 0,6 mg. $\mathrm{L}^{-1}$. No momento da coleta observava-se a ocorrência de contribuição de esgoto através do Canal do Jockey.

Observa-se na Figura 58 que a curva de OD decorrente da aplicação de 20 mg. $L^{-1}$ de peróxido apresentou um menor crescimento em relação à aplicação de $15 \mathrm{mg} . \mathrm{L}^{-1}$ (a partir de 0,5 dias), com perda de 5,0 mg. $\mathrm{L}^{-1}$ de oxigênio fornecido provavelmente relacionado à perda para a atmosfera. A concentração de saturação de OD da água no momento da coleta foi de $8,1 \mathrm{mg} . \mathrm{L}^{-1}$ (valor obtido pela tabela de concentração máxima de oxigênio dissolvido de acordo com a variação da temperatura - EPA, 2014).

Os resultados de decaimento das concentrações de peróxido podem ser observados na Figura 59, onde em menos de 12 horas ocorreu esgotamento do oxidante para as dosagens de $[1,0]$ e $[5,0] \mathrm{mg} . \mathrm{L}^{1}$. 


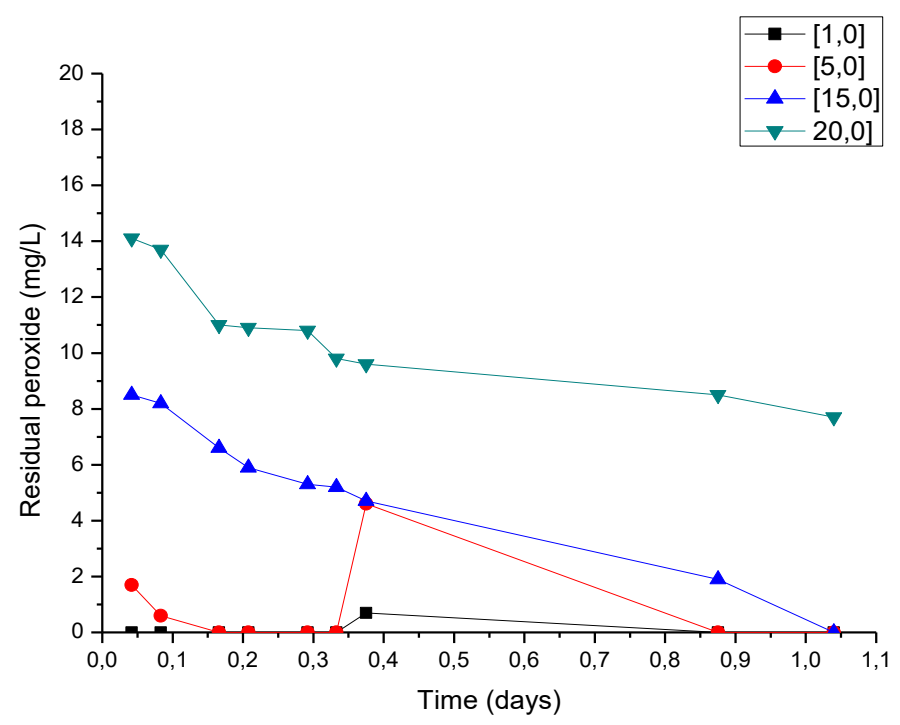

Figura 59 - Concentrações de peróxido residual a partir de 60 minutos $(0,042$ dias $)$ de início da reação com dosagens de $[1,0] ;[5,0] ;[15,0]$ e $[20] \mathrm{mg} \cdot \mathrm{L}^{-1}$. Em 0,37 dias houve nova adição de peróxido para as concentrações de $[1,0]$ e $[5,0] \mathrm{mg} \cdot \mathrm{L}^{-1}$. A precipitação acumulada ficou abaixo de $0,5 \mathrm{~mm}$ (RIO - ÁGUAS, 2014). A DBO 5 (no Ponto 3) foi de $24,0 \pm 0,6 \mathrm{mg} \cdot \mathrm{L}^{-1}$. No momento da coleta ocorria contribuição de esgoto através do Canal do Jockey.

Os resultados apresentados na Tabela 9 permitem verificar a velocidade inicial de decaimento do peróxido (em 60 minutos (0,042 dias) de início da reação) em diferentes concentrações. É possível observar que a partir de 15,0 mg. $L^{-1}$ não ocorre alteração significativa na velocidade de decaimento do oxidante. A Figura 60 também apresenta menor valor de $\mathrm{K}_{\mathrm{obs}}$ para a concentração de 20,0 mg.L $\mathrm{L}^{-1}$ de peróxido em comparação à aplicação de $15,0 \mathrm{mg} \cdot \mathrm{L}^{-1}$. Observase então que doses maiores que $15,0 \quad$ mg. $\mathrm{L}^{-1} \quad \mathrm{H}_{2} \mathrm{O}_{2}$ não aumentam significativamente o desempenho do processo quando aplicado à um corpo hídrico com características similares às apresentadas neste experimento. 
Tabela 9 - Velocidade inicial de decaimento das concentrações de peróxido em 60 minutos $(0,042$ dias $)$ de reação.

\begin{tabular}{|c|c|}
\hline $\begin{array}{c}{\left[\mathbf{H}_{2} \mathbf{O}_{2}\right] \text { inicial }} \\
(\mathbf{m g} / \mathbf{L})\end{array}$ & $\begin{array}{c}\text { Velocidade Inicial } \\
\left(\mathbf{V}_{\mathbf{0}}\right) \\
\left(\mathbf{m i n}^{-\mathbf{1}}\right)\end{array}$ \\
\hline 1,0 & 0,012 \\
\hline 5,0 & 0,05 \\
\hline 15,0 & 0,11 \\
\hline 20,0 & 0,098 \\
\hline
\end{tabular}
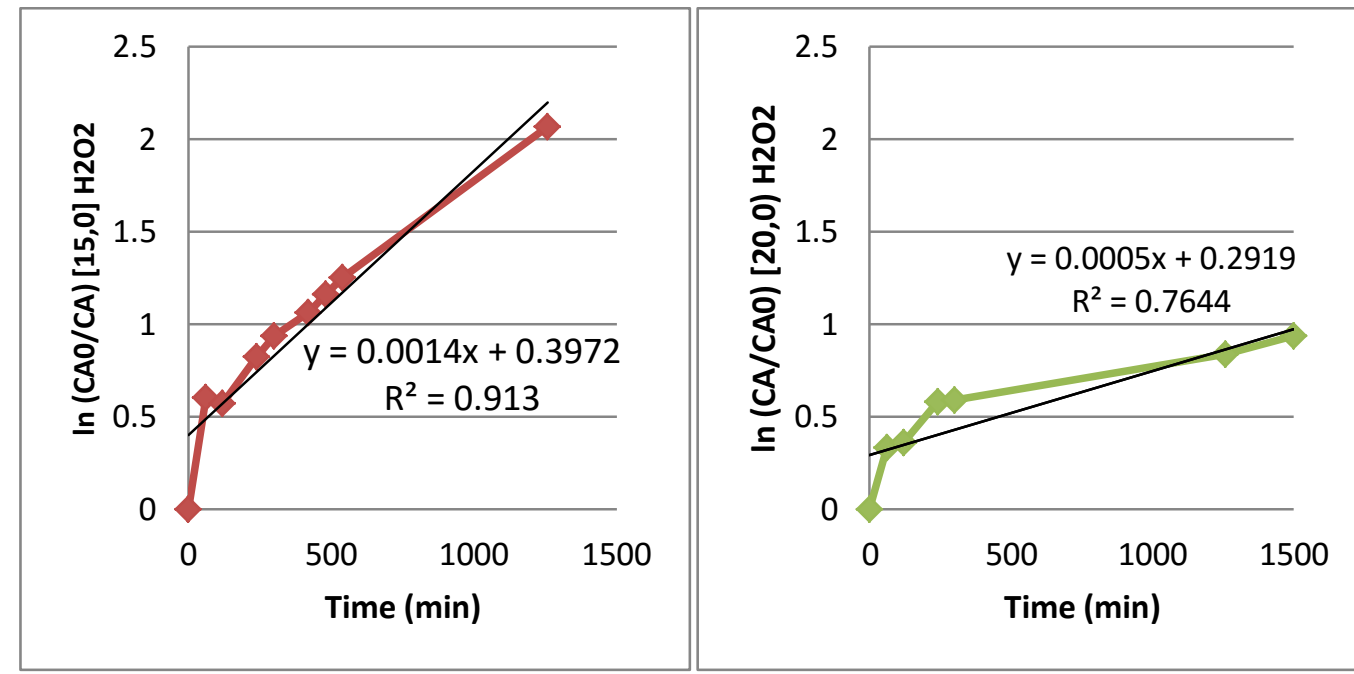

Figura 60 - Constantes cinéticas de pseudo-primeira ordem de decaimento do peróxido para as dosagens de $[15,0]$ e $[20,0] \mathrm{mg}^{-\mathrm{L}^{-1}}$ de $\mathrm{H}_{2} \mathrm{O}_{2}$ em água de rio contendo $24,0 \pm 0,6$ $\mathrm{mg} \cdot \mathrm{L}^{-1}$ de DBO. A precipitação acumulada do dia ficou abaixo de 0,5mm (RIO - ÁGUAS, 2014).

Ao analisar o decaimento do peróxido dentro dos limites ecotoxicológicos adotados neste estudo (valores de $\mathrm{H}_{2} \mathrm{O}_{2}$ abaixo de 1,0 mg. $\mathrm{L}^{-1}$ em 12 horas de reação como indicado pela Environment Agency), observa-se que apenas as dosagens iniciais de $[1,0]$ e $[5,0] \mathrm{mg} . \mathrm{L}^{-1}$ decaíram no tempo desejável, menor do que 24 hs.

Após 0,1 e 0,15 dias, as respectivas concentrações de [1,0] e [5,0] mg.. $\mathrm{L}^{-1}$ apresentaram esgotamento do oxidante (Figura 61). Em 0,37 dias efetuou-se as novas dosagens de reforço, simultaneamente. (Figura 62). 
Para VUILLEMIN et al. (2001), o tempo necessário para efetuar uma nova dosagem de oxidante para a reoxigenação da água é altamente dependente da taxa de respiração dos microorganismos. Este fato justifica o rápido esgotamento do peróxido dosado, já que a água analisada apresentava elevada concentração de DBO, parâmetro este, diretamente associado ao consumo de oxigênio pelos microorganismos presentes na água para efetuar a mineralização da matéria orgânica.

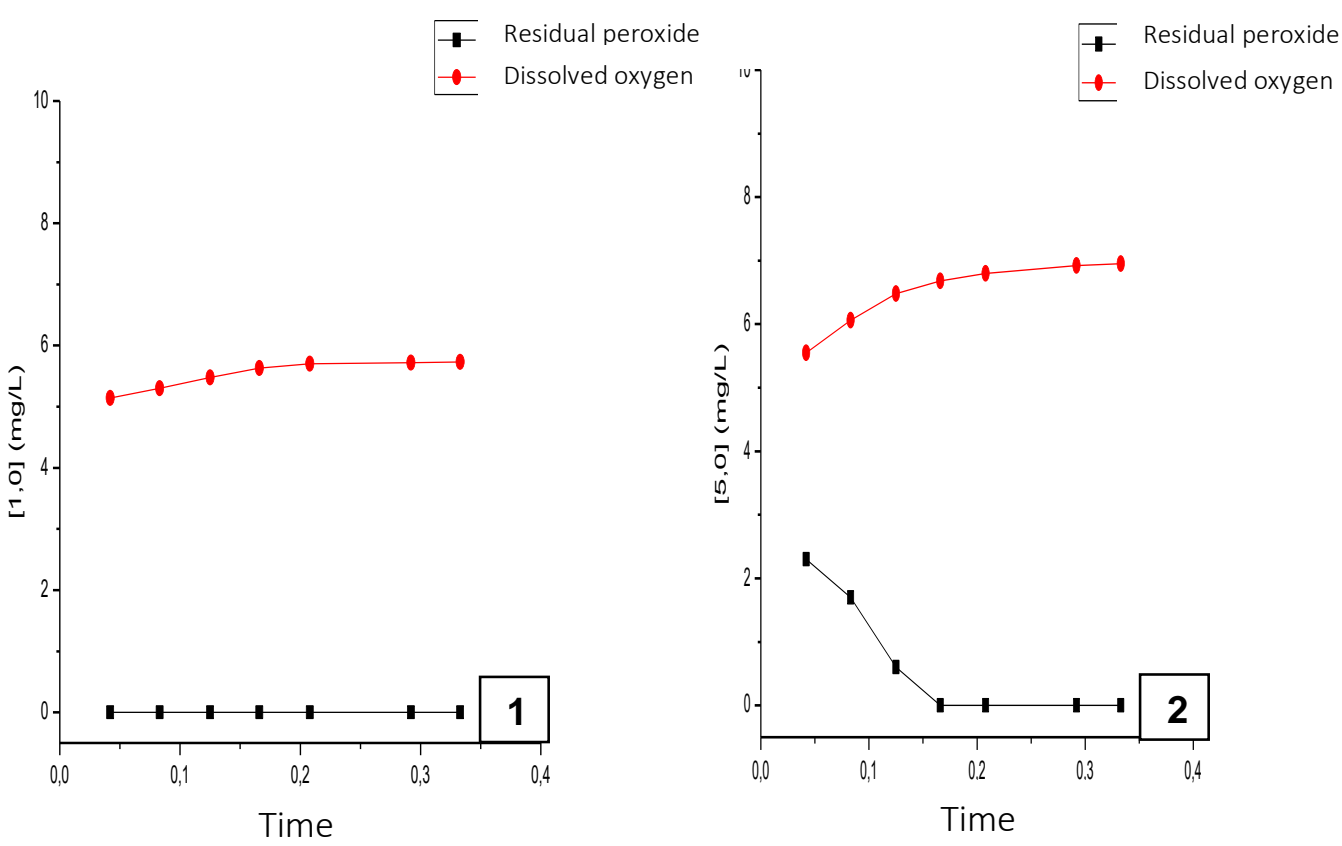

Figura 61 - Concentrações de peróxido residual da aplicação de $\mathrm{H}_{2} \mathrm{O}_{2}=[1,0](1)$ e $[5,0]$ (2) $\mathrm{mg} \cdot \mathrm{L}^{-1}$ e de oxigênio dissolvido, antes da reaplicação do oxidante em 0,37 dias de reação. 


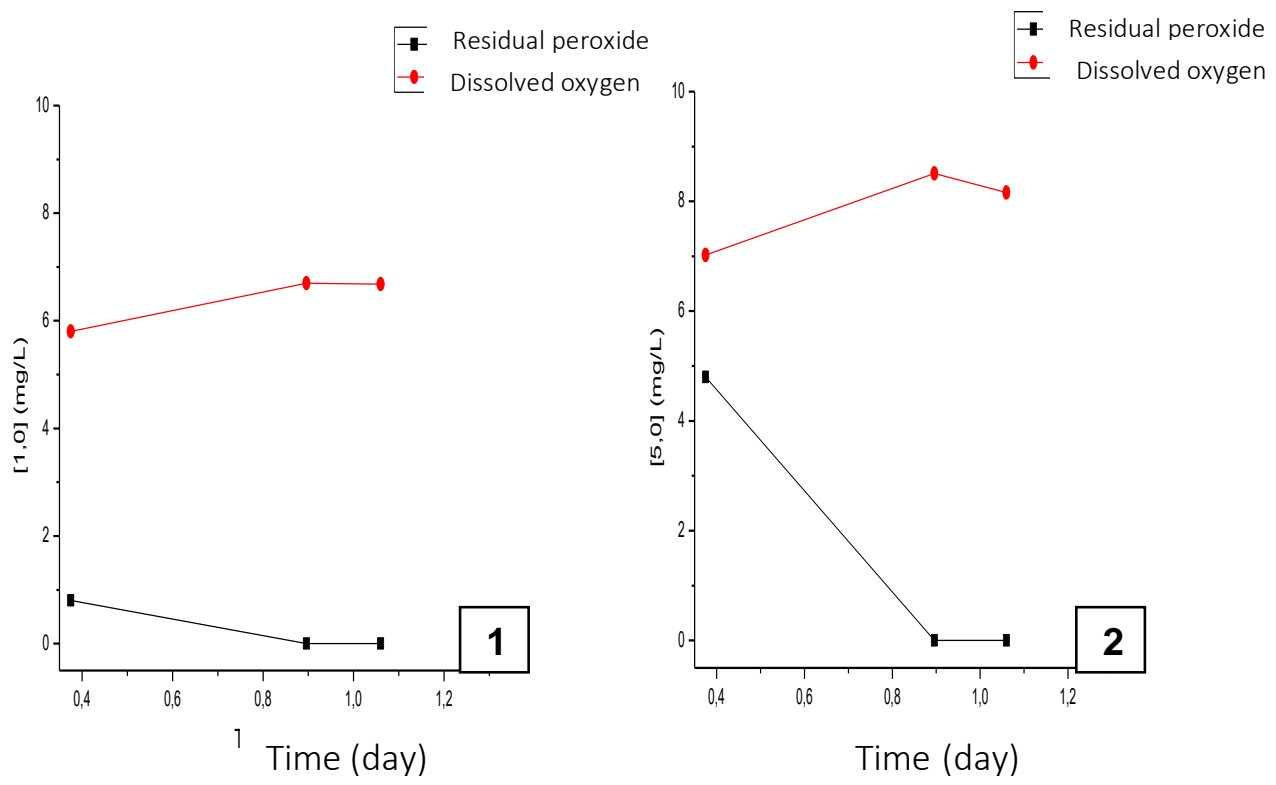

Figura 62 - Concentrações de peróxido residual da aplicação de $\mathrm{H}_{2} \mathrm{O}_{2}=[1,0](1)$ e $[5,0]$ (2) $\mathrm{mg} \cdot \mathrm{L}^{-1}$ e de oxigênio dissolvido, após reaplicação do oxidante em 0,37 dias de reação.

Ao comparar as dosagens de $[1,0]$ e $[5,0] \mathrm{mg} . \mathrm{L}^{-1}$ durante as 12 horas de reação, a concentração de 5,0 mg. $\mathrm{L}^{-1}$ apresentou uma maior velocidade inicial de decaimento do peróxido (Tabela 10) e maior fornecimento de OD à água, mostrando-se mais eficiente em relação à dosagem de $1,0 \mathrm{mg} . \mathrm{L}^{-1}$ para o corpo hídrico.

Plotando $\log \left(-d \frac{[\mathrm{H} 2 \mathrm{O} 2]}{d t}\right)$ em função de $\log \left[\mathrm{H}_{2} \mathrm{O}_{2}\right]$, obtêm-se os valores de $\alpha$ e $\mathrm{K}_{\text {H2O2ap. }}$ A ordem aparente da reação $(\alpha)$ é apresentada na Figura 63. 


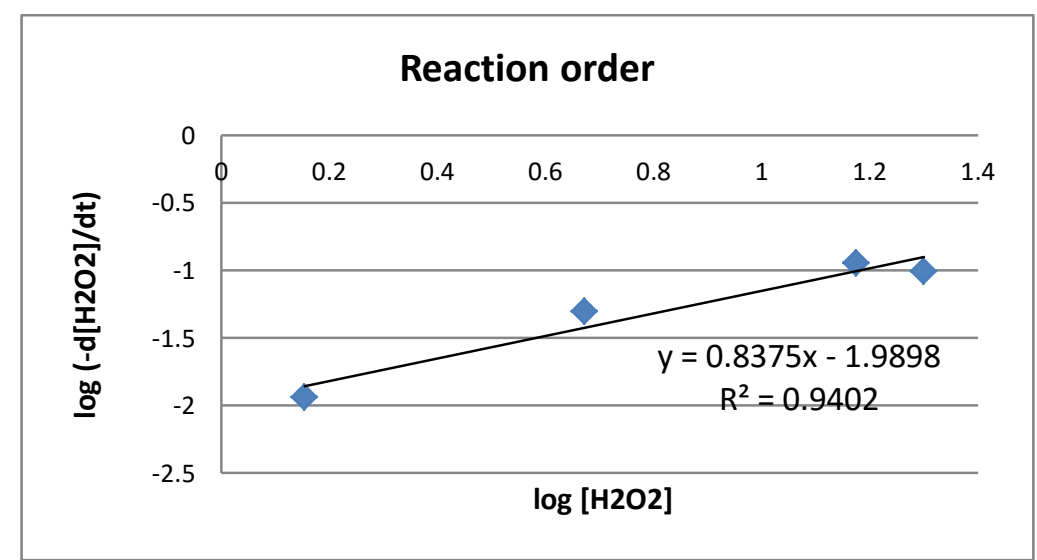

Figura 63 - Ordem aparente de reação de decaimento do $\mathrm{H}_{2} \mathrm{O}_{2}$ de acordo com a velocidade inicial das dosagens de [1,0], [5,0], [15,0] e [20,0] mg.L-1 de $\mathrm{H}_{2} \mathrm{O}_{2}$ em água de rio contendo $24,0 \pm 0,6 \mathrm{mg} \cdot \mathrm{L}^{-1}$ de $\mathrm{DBO}_{5}$. No momento da coleta ocorria contribuição do Canal do Jockey. A precipitação acumulada do dia ficou abaixo de $0,5 \mathrm{~mm}$ (RIO ÁGUAS, 2014).

\section{Experimento 4 (Coleta 7)}

Com o objetivo de verificar o efeito de menores dosagens de peróxido em águas com baixa concentração de oxigênio dissolvido, foram dosadas na água de estudo as seguintes concentrações de $\mathrm{H}_{2} \mathrm{O}_{2}$ : [1,5]; [3,0] e [5,0] mg. $\mathrm{L}^{-1}$.

A Figura 64 apresenta resultados de oxigênio dissolvido antes e após as respectivas dosagens de peróxido em amostras coletadas em dia de precipitação de 13,2 mm e [COT] de 7,0 mg. $\mathrm{L}^{-1}$. A temperatura foi a maior observada entre as coletas $\left(27,5^{\circ} \mathrm{C}\right)$, sendo responsável por uma menor concentração de saturação de OD na água $\left(7,95 \mathrm{mg} \cdot \mathrm{L}^{-1}\right)$. O valor de déficit de oxigênio inicial $\left(\mathrm{D}_{0}\right)$ obtido foi de 3,85 mg.L $\mathrm{L}^{-1}$ (para a temperatura inicial da água). Observa-se que a concentração de OD estava abaixo do limite estabelecido pela Resolução 357/05 do CONAMA, onde para os rios de classe 2, o valor de oxigênio dissolvido não pode ser inferior a 5,0 mg. $\mathrm{L}^{-1}$. 


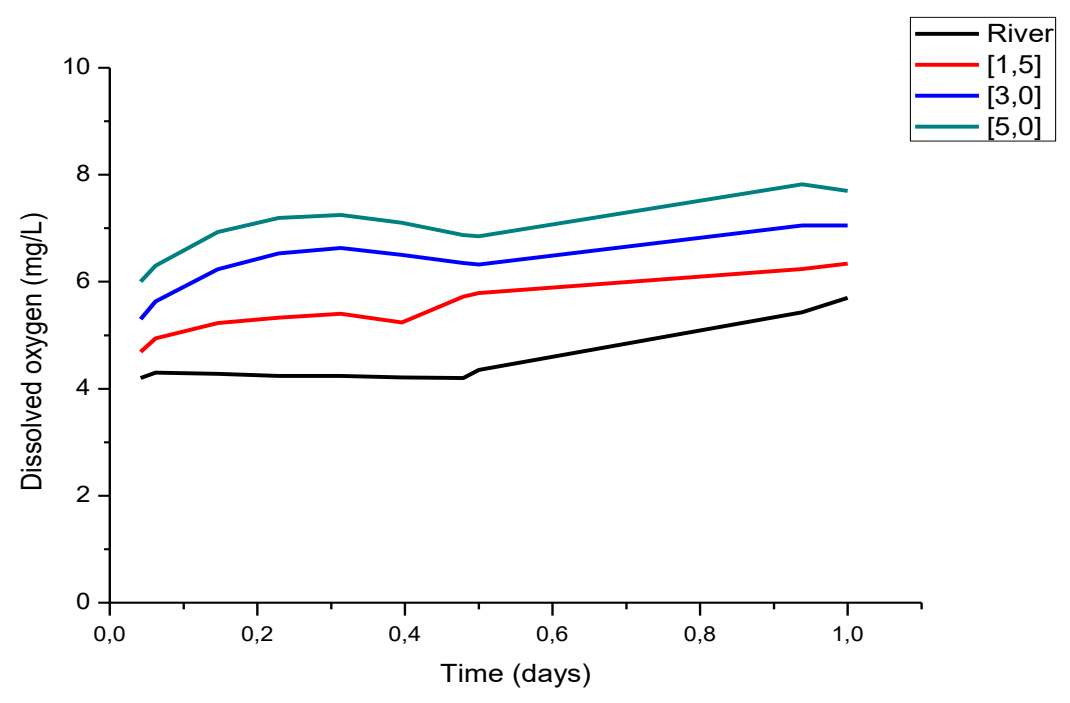

Figura 64 - Concentração de oxigênio dissolvido do rio em amostras com adições de [1,5]; [3,0] e [5,0] mg. $\mathrm{L}^{-1}$ de $\mathrm{H}_{2} \mathrm{O}_{2}$ e amostra sem adição de $\mathrm{H}_{2} \mathrm{O}_{2}$ (river) a partir de 0,042 dias (60 minutos). Em 0,39 dias houve nova adição de peróxido para a concentração de $[1,5] \mathrm{mg} \cdot \mathrm{L}^{-1}$. Em 0,5 dias houve nova adição de peróxido para as concentrações de $[3,0]$ e [5,0] mg. L $^{-1}$ A precipitação acumulada do dia foi 13,2 mm (RIO - ÁGUAS, 2014). A concentração de COT (no Ponto 3) foi de $7,0 \mathrm{mg} \cdot \mathrm{L}^{-1}$.

Os resultados da Figura 64 mostram que a curva de OD da amostra do rio retirada no Ponto 3 do Canal sem aplicação de peróxido de hidrogênio manteve uma concentração estável em torno de 4,2 mg. $\mathrm{L}^{-1}$ até as 12 horas de observação, ocorrendo uma elevação a partir deste tempo, fator este característico da reaeração natural do corpo hídrico. Podemos perceber que próximo ao término do teste (1 dia), ocorreu um processo de recuperação do nível de OD, alcançando valores aceitáveis pela Resolução 357/05 do CONAMA (a partir de 5,0 mg. $\mathrm{L}^{-1}$ ). Este fato pode ser justificado segundo VON SPERLING (1996), devido à capacidade dos rios de recuperar suas concentrações de OD graças ao fenômeno natural de autodepuração de suas águas, situação em que os compostos orgânicos são convertidos em grande parte em compostos inertes. A partir de então, a concentração de oxigênio reaerada para o corpo hídrico é consumida em menores concentrações pelos microorganismos presentes. Este processo de autodepuração admite um modelamento matemático devido a Streeter - Phelps (STREETER \& PHELPS, 1925) em que se considera a cinética de duas reações que ocorrem paralelamente: (1) O consumo de OD na bio-oxidação da matéria orgânica dissolvida proveniente do esgoto, e (2) a reoxigenação natural do corpo hídrico 
impulsionada pela pressão parcial de $\mathrm{O}_{2}$ na atmosfera, através da interface com água.

Durante o curso do experimento foi possível observar que tanto a amostra somente com água do rio e a amostra dosada com [1,5] $\mathrm{H}_{2} \mathrm{O}_{2}$ mg.L $\mathrm{L}^{-1}$ alcançaram valores de OD de 5,4 mg. $\mathrm{L}^{-1}$ em tempos significativamente diferentes; onde a água do rio sem adição de $\mathrm{H}_{2} \mathrm{O}_{2}$ necessitou de 22,5 hs para alcançar valores de OD de 5,4 mg.L $\mathrm{L}^{-1}$, enquanto a água dosada com $[1,5] \mathrm{H}_{2} \mathrm{O}_{2} \mathrm{mg} . \mathrm{L}^{-1}$ necessitou de 7,5 hs para alcançar a referente concentração de OD. Segundo TUNAY et al. (2010), a taxa de reaeração natural é lenta, o que justifica o maior tempo demandado pelo rio para recuperar-se a níveis mínimos preconizados pela Legislação. Verifica-se então a relevância do uso do peróxido em casos como este, em que a concentração de OD está abaixo do permissível para a vida aquática, e há um lento processo de reaeração natural do corpo hídrico, o que pode ocasionar em episódios de mortandade de determinadas espécies caso a demanda de OD continue a ser superior ao tempo necessário para reaeração do rio.

Os valores de OD fornecidos às amostras após as dosagens do peróxido não apresentaram perdas significativas (os valores ficaram abaixo de 1,0 mg.L $\mathrm{L}^{-1}$ ).

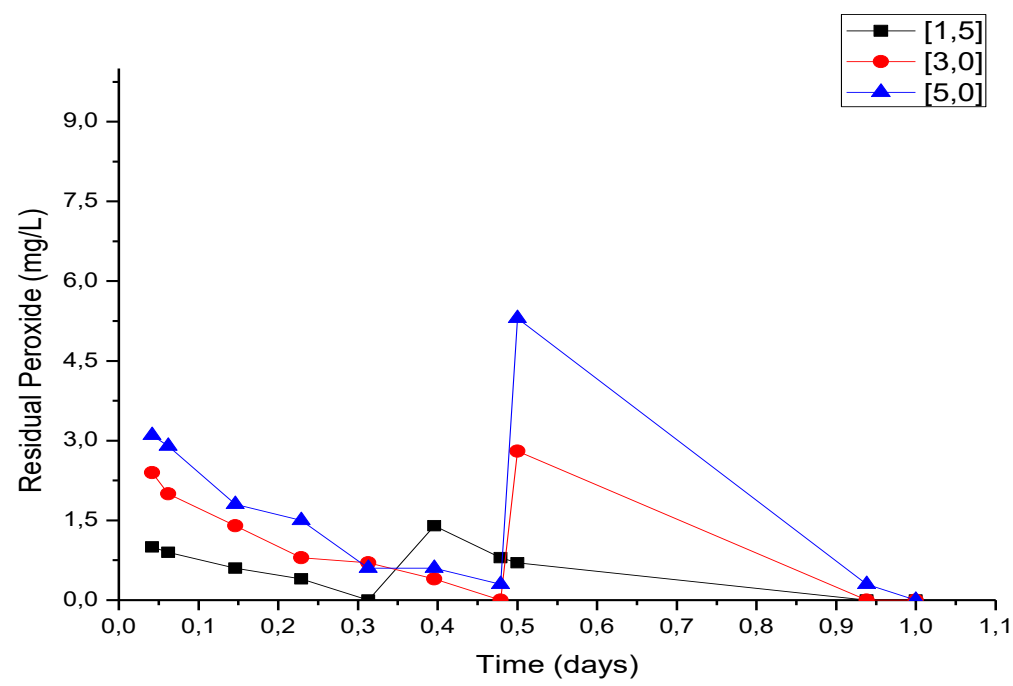

Figura 65 - Concentrações de peróxido residual a partir de 60 minutos $(0,042$ dias $)$ de início da reação com dosagens de $[1,5] ;[3,0]$ e $[5,0] \mathrm{mg} \cdot \mathrm{L}^{-1}$. Em 0,39 dias houve nova adição de peróxido para a concentração de $[1,5] \mathrm{mg} \cdot \mathrm{L}^{-1}$. Em 0,5 dias houve nova adição de peróxido para a concentração de $[1,5] \mathrm{mg} \cdot \mathrm{L}^{-1}$. Em 0,5 dias houve nova adição de peróxido para as concentrações de $[3,0]$ e $[5,0] \mathrm{mg}^{-L^{-1}}$. A precipitação acumulada do dia foi $13,2 \mathrm{~mm}$ (RIO - ÁGUAS, 2014). A [COT] (no Ponto 3) foi de 7,0 $\mathrm{mg}^{\mathrm{L}} \mathrm{L}^{-1}$. 
É possível observar (Figura 65), que todas as concentrações apresentaram valores de peróxido abaixo de $1,0 \mathrm{mg} . \mathrm{L}^{-1}$ em 12 horas de reação como recomendado pela Environment Agency. Em 0,39 dias houve necessidade de nova aplicação de peróxido na amostra teste de $1,5 \mathrm{mg} . \mathrm{L}^{-1}$ devido ao esgotamento do oxidante neste tempo. As concentrações de peróxido de $[3,0]$ e $[5,0] \mathrm{mg} . \mathrm{L}^{-1}$ apresentaram valores de $[0,0]$ e $[0,3]$ mg. $\mathrm{L}^{-1}$ em 0,5 dias (12 horas) respectivamente, havendo necessidade de reaplicação do oxidante.



Figura 66 - Concentrações de peróxido residual da aplicação de $\mathrm{H}_{2} \mathrm{O}_{2}=[1,0](1)$ e $[5,0]$ (2) $\mathrm{mg} \cdot \mathrm{L}^{-1}$ e de oxigênio dissolvido, antes da reaplicação do oxidante em 0,5 dias de reação. 


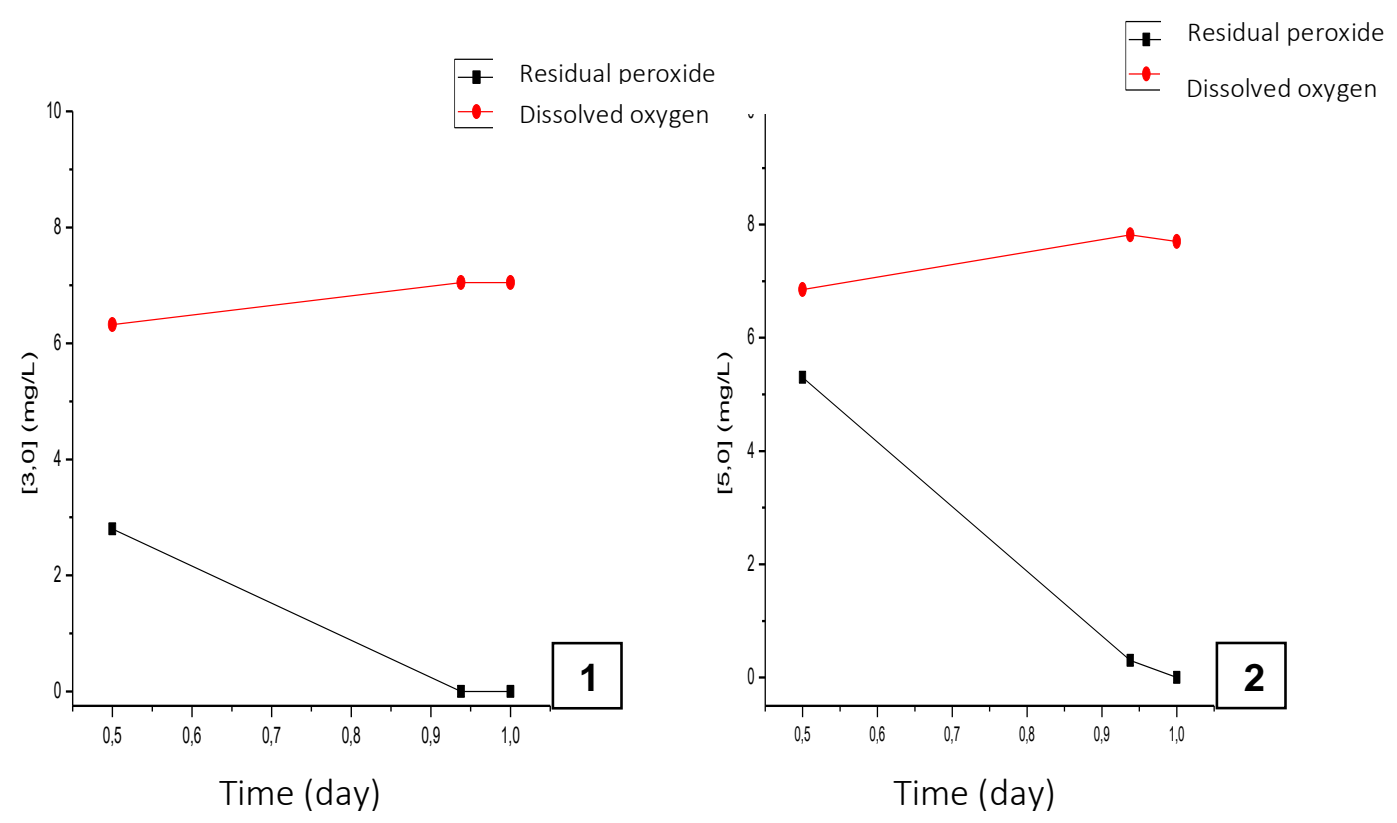

Figura 67 - Concentrações de peróxido residual da aplicação de $\mathrm{H}_{2} \mathrm{O}_{2}=[1,0](1)$ e $[5,0]$ (2) $\mathrm{mg} \cdot \mathrm{L}^{-1}$ e de oxigênio dissolvido, após reaplicação do oxidante em 0,5 dias de reação.

Os resultados da Figura 68 permitem verificar a constante cinética $\left(\mathrm{k}_{\mathrm{obs}}\right)$ em diferentes concentrações. As dosagens apresentaram velocidades de decaimento de $\mathrm{H}_{2} \mathrm{O}_{2}$ próximas. Esses valores encontrados justificam o decaimento observado das concentrações de $\mathrm{H}_{2} \mathrm{O}_{2}$ durante o experimento, onde tanto a dosagem de [3,0] quanto a de [5,0] esgotaram-se em tempos próximos, demandando uma reaplicação do oxidante ao mesmo tempo.

Nota-se então, que o uso da concentração de 5,0 mg. $\mathrm{L}^{-1}$ é aplicável para corpos hídricos que apresentem as características observadas neste estudo. 

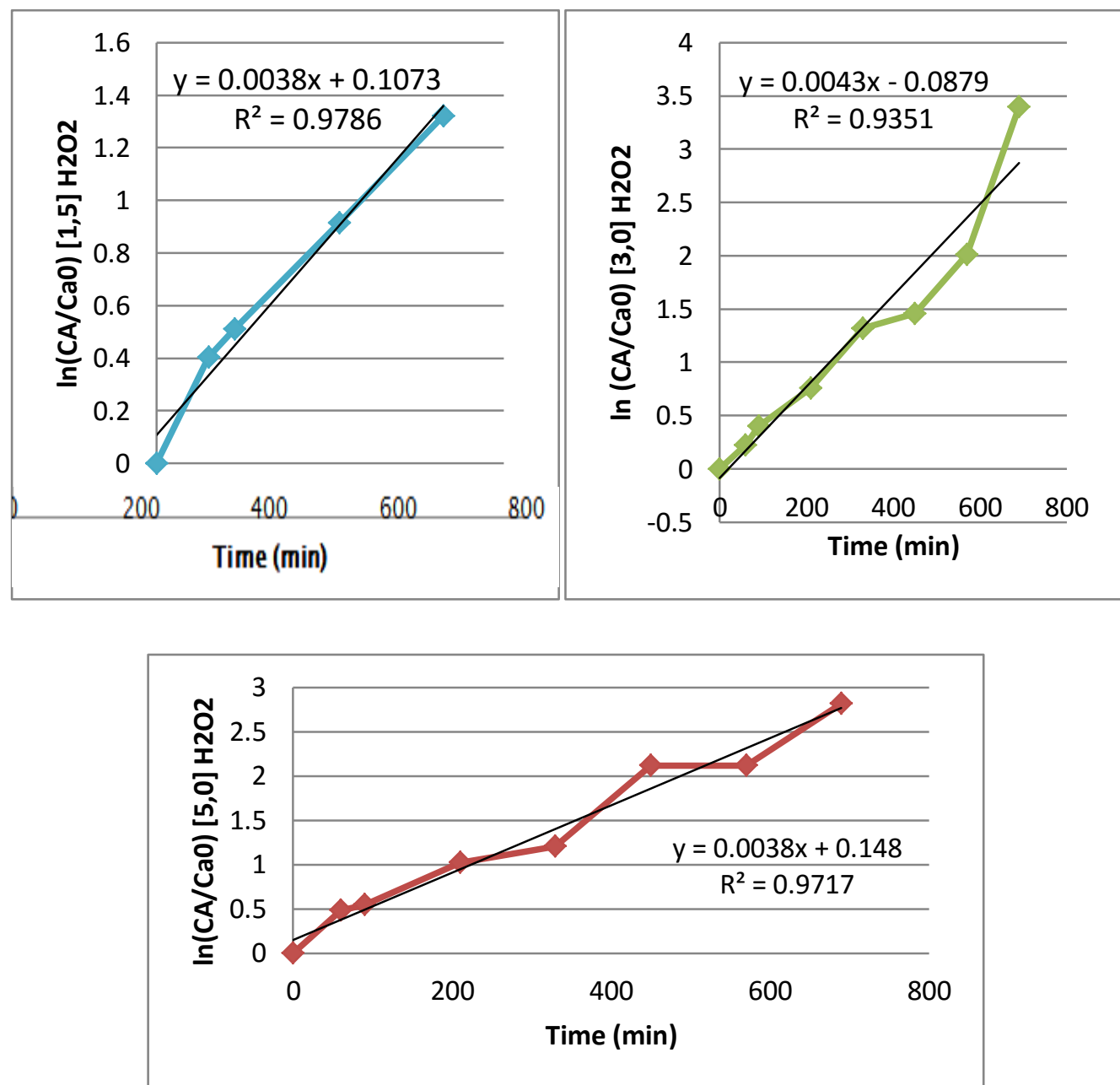

Figura 68 - Constantes cinéticas de pseudo-primeira ordem de decaimento do peróxido para as dosagens de $[15,0]$ e $[20,0] \mathrm{mg} \cdot \mathrm{L}^{-1}$ de $\mathrm{H}^{2} \mathrm{O}^{2}$ em água de rio contendo $7,0 \mathrm{mg} \cdot \mathrm{L}^{-1}$ de COT. A precipitação acumulada do dia ficou abaixo de 0,5mm (RIO - ÁGUAS, 2014).

Plotando $\log \left(-d \frac{[\mathrm{H2O} 2]}{d t}\right)$ em função de $\log \left[\mathrm{H}_{2} \mathrm{O}_{2}\right]$, obtêm-se os valores de $\alpha$ e $\mathrm{K}_{\mathrm{H} 2 \mathrm{O} 2 \mathrm{ap} .}$ A ordem aparente da reação $(\alpha)$ é apresentada na Figura 69. 


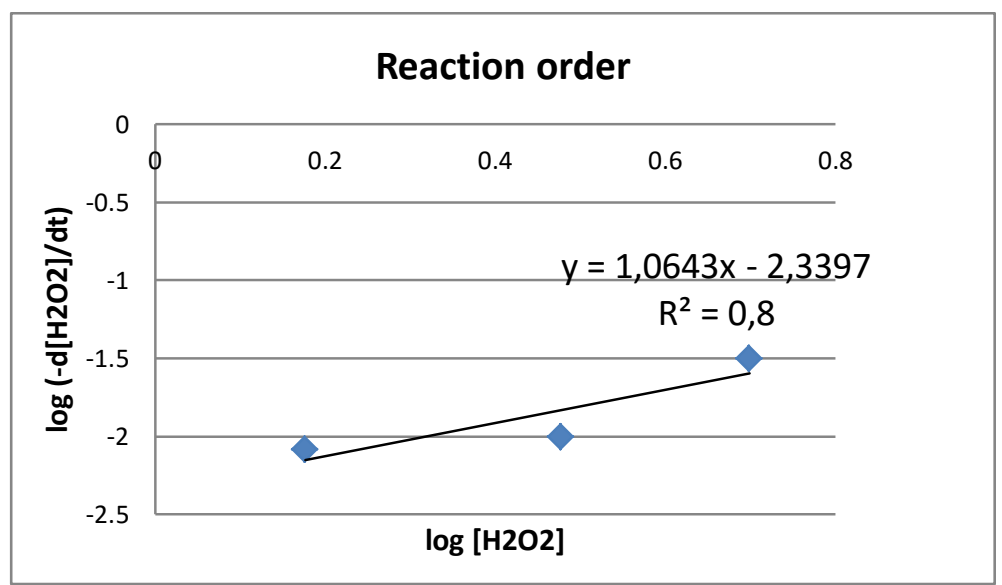

Figura 69 - Ordem aparente de reação de decaimento do $\mathrm{H} 2 \mathrm{O} 2$ de acordo com a velocidade inicial obtida das dosagens de [1,5], [3,0] e [5,0] mg.L-1 de H2O2 em água de rio contendo 7,0 mg.L-1 de COT. No momento da coleta ocorria contribuição de esgoto através Canal do Jockey. A precipitação acumulada do dia foi de 13,2 mm (RIO ÁGUAS, 2014).

A tabela 10 apresenta os valores das constantes cinéticas de pseudoprimeira ordem de decaimento do peróxido de hidrogênio de acordo com a velocidade inicial da reação obtidas nos experimentos.

Tabela 10 - Constantes cinéticas de pseudo-primeira ordem de decaimento do $\mathrm{H} 2 \mathrm{O} 2$ de acordo com a velocidade inicial da reação. Os valores são referentes aos experimentos 1, 2, 3 e 4 de dosagem de $\mathrm{H}_{2} \mathrm{O}_{2}$ em água de rio obtida do ponto de amostragem 3 do Canal Gal. Garzón em diferentes eventos de precipitação.

\begin{tabular}{|c|c|c|c|c|c|}
\hline $\begin{array}{c}\text { Exp. } \\
\mathbf{n}^{\mathbf{0}}\end{array}$ & $\begin{array}{c}\text { Coleta/precipitação } \\
(\mathbf{m m})\end{array}$ & $\begin{array}{c}\text { DBO } \\
\left(\mathbf{m g . L} \mathbf{L}^{-\mathbf{1}}\right)\end{array}$ & $\begin{array}{c}\text { COT } \\
(\mathbf{m g . L} \\
\mathbf{1})\end{array}$ & $\begin{array}{c}\mathbf{K}_{\mathbf{~ o b s}} \\
\left(\mathbf{m i n}^{-\mathbf{1}}\right)\end{array}$ & $\mathbf{r}$ \\
\hline & & & & & \\
1 & Coleta $1 / 0,8$ & 2,0 & - & 0,0018 & 0,9395 \\
2 & Coleta 2/<0,5 & 1,4 & 1,0 & 0,00172 & 0,9 \\
3 & Coleta 3/ <0,5 & 24,0 & - & 0,01023 & 0,9402 \\
4 & Coleta 7/ 13,2 & - & 7,0 & 0,00457 & 0,8 \\
\hline
\end{tabular}

Os experimentos com água do rio com maiores concentrações de matéria orgânica foram os que apresentaram as maiores velocidades de decaimento do oxidante em 24 horas. Essas maiores [MO] foram encontradas após alta taxa de 
precipitação - coleta 7 (o que favorece maior volume de material orgânico e íons dissolvidos carreados) e em evento de poluição pontual por esgoto - coleta 3 (evidência visual) pelo Canal do Jockey Clube.

Além da possível influência dos íons dissolvidos, o que foi observado são maiores constantes cinéticas na presença de maiores [MO]. Além de uma maior concentração de substrato orgânico para ser oxidado pelo peróxido, podemos supor que ocorra influência de alguma substância orgânica presente com ou/ no material orgânico com efeito catalítico sobre a decomposição do peróxido, como a enzima catalase. Para ARVIN e PEDERSEN (2015), o peróxido de hidrogênio degrada exponencialmente, dependendo da concentração de matéria orgânica medida, como por exemplo, pela demanda bioquímica de oxigênio $\left(\mathrm{DBO}_{5}\right)$ da água.

Segundo GEORGE (1947), quando a catalase atua sobre o $\mathrm{H}_{2} \mathrm{O}_{2}$, há uma rápida evolução inicial de oxigênio sobre o meio. Quanto maior a concentração do peróxido, mais intensa será a atuação da catalase sobre este. HOSETTI e FROST (1994) verificaram em amostras de água do rio Tungabhadra (Índia) que recebe descargas de efluentes industriais que, zonas do rio com elevada DBO apresentavam os maiores níveis em atividade catalítica, sendo estes níveis verificados através de micromoles de peróxido de hidrogênio decomposto em $\min . / 100 \mathrm{~mL}$ de amostra.

Em suma, o que ocorre é que com o aumento dos níveis de poluição orgânica, as bactérias tornam-se mais ativas, produzindo mais enzima catalase para remover das células o $\mathrm{H}_{2} \mathrm{O}_{2}$ a uma taxa mais rápida. $\mathrm{O}$ teor orgânico é estabilizado pela ação das populações microbianas e com a diminuição do número de microrganismos, os níveis de catalase também diminuem (HOSETTI e FROST, 1993). Tal enzima está presente como já citado em células vegetais, animais e em microorganismos. Como a taxa de crescimento dos microorganismos aeróbios é dependente do grau de poluição orgânica local, possivelmente, o que pode ocorrer é um aumento da atividade catalítica a partir da enzima catalase presente na população de microorganismos e vegetais durante eventos de maior precipitação e eventos de contaminação. 
Este aumento da taxa de reação de acordo com o aumento da $\left[\mathrm{H}_{2} \mathrm{O}_{2}\right]$ e aumento da [MO] foi verificado nas figuras 57, 60 e 68 .

\subsubsection{Eficiência de remoção da matéria orgânica após dosagens de $\mathrm{H}_{2} \mathrm{O}_{2}$}

Foram obtidos resultados de remoção do material orgânico através das frações de COT (Figura 70) do ultimo teste realizado (Experimento 4). O objetivo foi verificar a influência das dosagens de peróxido sobre a remoção da matéria orgânica após o tratamento (tempo reacional de 24 horas).

Para mensurar a eficiência do peróxido testado como oxidante, foi calculada a eficiência de remoção através da Equação 12.

$$
\operatorname{Remoção~}(\%)=\left(\left(\mathbf{X}_{\mathrm{A}}-\mathbf{X}_{\mathrm{B}}\right) / \mathbf{X}_{\mathrm{A}}\right) \times 100
$$

Onde: $\mathrm{X}_{\mathrm{A}}$ corresponde aos valores do parâmetro analisado antes do tratamento e $\mathrm{X}_{\mathrm{B}}$, por sua vez, corresponde aos valores do parâmetro após o tratamento.

Os resultados apresentaram taxas de remoção de $9,04 \%, 12,7 \%$ e $15,7 \%$ para as dosagens de $[1,5]$, $[3,0]$ e $[5,0] \mathrm{H}_{2} \mathrm{O}_{2} \mathrm{mg} . \mathrm{L}^{-1}$ respectivamente. 


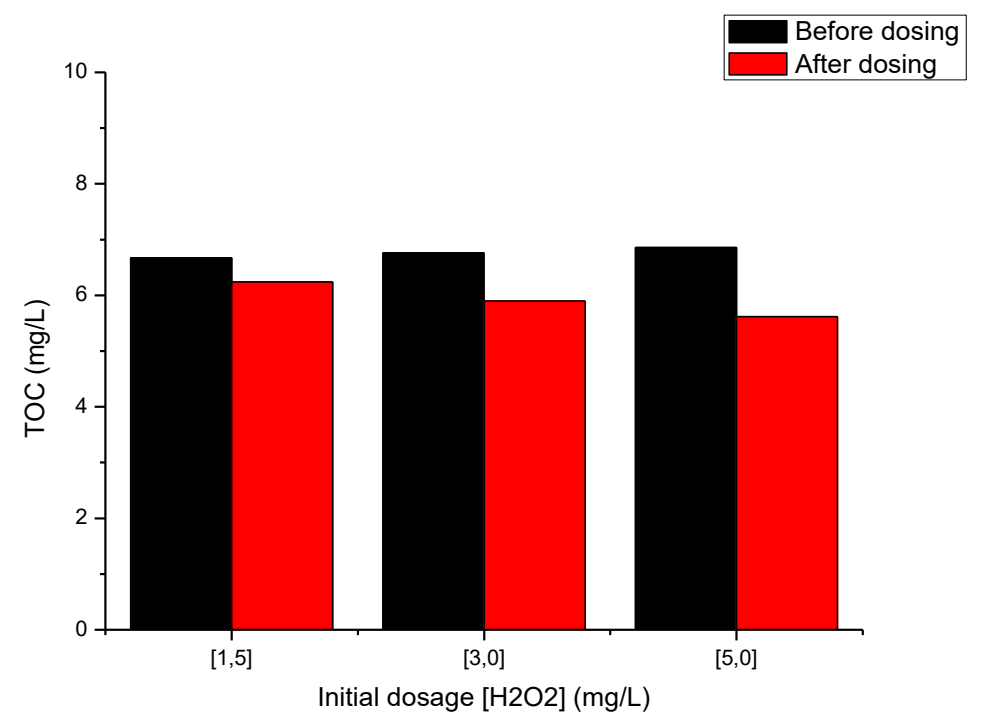

Figura 70 - Concentração de COT antes e após dosagem de [1,5], $[3,0]$ e $[5,0] \mathrm{H}_{2} \mathrm{O}_{2}$ mg. $\mathrm{L}^{-1}$. Os resultados referentes às concentrações de $\mathrm{H}_{2} \mathrm{O}_{2}$ após dosagem foram verificados ao término do tempo reacional de 24 hs. A precipitação acumulada do dia foi 13,2 mm (RIO - ÁGUAS, 2014).

Observa-se uma baixa redução de COT para as dosagens aplicadas. Este fato é compreendido devido à baixa eficiência do peróxido (em baixas concentrações) em oxidar compostos orgânicos sem adição de reagentes e/ou processos ativadores tais como os POAs, apresentando uma reação de oxidação cineticamente lenta, onde parte do oxidante que demora a reagir acaba decompondo-se em água e oxigênio. De acordo com MALAIANDY et al. (1980), em alguns casos a decomposição do próprio oxidante predomina sobre a oxidação das espécies orgânicas e resulta em perda excessiva do peróxido. Segundo DANTAS (2005), usualmente, a oxidação de compostos orgânicos utilizando apenas o peróxido ocorre a velocidades muito baixas. Já a combinação de luz UV com o agente oxidante, por exemplo, ou outros processos / reagentes ativadores é sempre mais eficiente do que apenas a utilização do oxidante isolado. Devido a este motivo, estudos voltados à degradação de compostos orgânicos e inorgânicos utilizando peróxido são avaliados em conjunto com outros processos, como com a adição de íons Fe (processo Fenton), radiação UV, entre outros.

REINA et al. (2012), ao avaliarem a eficiência do processo Foto-Fenton em amostras de águas residuais contendo paracetamol como poluente-alvo, observaram que os radicais formados nas primeiras reações do peróxido em 
contato com poluente podiam ter uma via de reação direta com a matéria orgânica; ou poderiam ser perdidos em reações ineficazes com o peróxido de hidrogênio; ou, levar à geração de $\mathrm{O}_{2}$, o que reflete em um aumento de OD no efluente.

No presente estudo, o que foi observado é que durante a ocorrência das reações em paralelo do peróxido (reação de oxidação e decomposição), a reação prevalecente foi a de decomposição do oxidante, indicando uma melhor eficiência do peróxido na suplementação de oxigênio dissolvido (um dos produtos do processo de decomposição) para o corpo hídrico em relação à eficiência de degradação da matéria orgânica.

\subsubsection{Possibilidades de aplicação da depuração acelerada em águas de rios poluídos sobre a LRF}

No caso da bacia hidrográfica de estudo, os rios que afluem à Lagoa Rodrigo de Freitas são rios de comprimento inferior a 4,5 km, sendo o Rio dos Macacos o de maior extensão, com 4,46 Km desde a nascente à foz da Lagoa (AMBIENTAL, 2012), sendo ainda verificada uma alta declividade do leito do mesmo, e velocidade de escoamento superficial de $92 \mathrm{~km} / \mathrm{h}$. O tempo de concentração da bacia, ou seja, o tempo necessário para que toda a bacia contribua para seu exutório, foi estimado por MIGUEZ et al. (2012) em cerca de 70 minutos.

Durante os experimentos realizados no presente estudo, não foi observado decréscimos significativos de OD (com déficits acima de $1,0 \mathrm{mg} . \mathrm{L}^{-1}$ ) antes de 60 minutos de medição. Sendo assim, é pouco provável que haja tempo suficiente para que possam ocorrer episódios críticos de baixo OD durante o percurso da água dos rios durante eventos de elevada precipitação pelo canal de estudo. O que pode ocorrer é que tais rios contaminados já apresentem baixas concentrações de OD durante o percurso a montante do canal (apesar da diluição da chuva), sendo que o volume de transbordo desses rios contaminados em dias de fortes chuvas possa ameaçar o nível do OD na água da LRF na região da pluma de água doce poluída, avançando sobre a água da Lagoa em períodos pré-críticos que esta já apresente também baixas concentrações de OD. Note-se que em extensos corpos 
d'água como a LRF ou a Baía de Guanabara a redução crítica de OD provocada por lançamento de contaminantes com potencial de consumo de OD em uma extensão significativa do corpo hídrico pode resultar em mortandade de peixes ainda que a maior parte do corpo d'água não tenha sido afetada (conforme noticiado com foto em O GLOBO, 18/3/2015).

Embora ocorra diluição dessa pluma à medida de seu avanço, a aplicação do peróxido pode assegurar a manutenção de OD > $5 \mathrm{mg} / \mathrm{L}$ no corpo da pluma, pois já foi observado por autores como DE PAULA (2009) que a área próxima à Ilha Piraquê apresenta velocidades com pequenas variações e fracas correntes de circulação de água. Segundo o autor, as descargas fluviais influenciam razoavelmente na composição das águas da LRF numa faixa de 800 metros a partir da margem leste da Ilha do Piraquê, demonstrando diluição menos acentuada, com plumas de água menos renovada.

WEELRET et al. (2012) ressalvam que a chuva que cai diretamente sobre a Lagoa pode em um primeiro momento diluir os microorganismos presentes na superfície da coluna d'água, mas a seguir, a água lixiviada de seu entorno, bem como a água da bacia hidrográfica juntam-se ao corpo d'água carreando microorganismos, e neste momento é de se esperar um aumento na sua densidade. Como consequência, este aumento de densidade populacional de microorganismos poderá ocasionar uma expressiva velocidade de demanda de oxigênio para biodegradar as substâncias advindas das águas pluviais e fluviais.

Deve-se então atentar durante tais episódios de precipitação à concentração de OD presente na LRF antes mesmo do evento de deságue dos rios, o que pode potencializar déficits críticos de oxigênio ao ocorrer o deságue das águas da bacia, podendo influenciar no processo de depuração das águas. AMBIENTAL (2012) ao medir a [OD] no período de janeiro de 1996 a março de 2001 no ponto central da Lagoa, observou uma grande variabilidade. Os valores oscilaram entre $0,6 \mathrm{mg} \cdot \mathrm{L}^{-1}$ a 22,0 mg. $\mathrm{L}^{-1}$. Segundo o autor, valores inferiores a $5,0 \mathrm{mg} . \mathrm{L}^{-1}$ foram registrados em diversos pontos da Lagoa em diferentes coletas. Estes valores violam os padrões estabelecidos para o CONAMA No 357/05 para águas salobras de Classe 2, onde a concentração de OD não deve ser inferior a 4,0 mg.L L $^{-1}$. WEELRET et al. (2012) apresentou em seus estudos em 2012 valores de 
OD na Lagoa próximo ao Jockey Clube de 2,87 mg. $\mathrm{L}^{-1}$ na superfície e 1,5 mg. $\mathrm{L}^{-1}$ no fundo.

Um melhor entendimento e estudos mais aprofundados sobre a diluição da pluma de poluentes que deságua na LRF é necessário para um manejo mais eficiente do peróxido de hidrogênio sobre os corpos hídricos deste estudo. Porém, independentemente da aplicação ao sistema lagunar da LRF, o peróxido mostrouse eficiente ao fornecimento de oxigênio dissolvido e consequentemente ao processo de depuração acelerada em água de rios poluídos por material orgânico. 


\section{Conclusões}

1. Verificou-se a ocorrência de variação temporal de parâmetros analisados: SST e COT, na água do canal da Rua General Garzon, onde durante maiores taxas de precipitação pluviométrica ocorreu aumento das concentrações de carbono orgânico e sólidos suspensos no corpo hídrico devido principalmente ao escoamento superficial. Além da precipitação, fatores como lançamento e contribuição de poluição pontual, através do Rio Cabeça e do Canal do Jockey influenciaram os parâmetros de qualidade do corpo hídrico da Bacia de estudo em ponto de amostragem próximo ao transbordo eventual desses rios sobre a LRF , apresentando em determinadas coletas desconformidade com parâmetros OD e DBO estabelecidos pela Resolução CONAMA 357 / 2005 para água salobra de classe 2.

2. Testes de dosagem de peróxido de hidrogênio aplicados em amostras do rio com maiores concentrações de material orgânico apresentaram maior $\mathrm{k}_{\mathrm{obs}} \mathrm{de}$ decomposição do peróxido. Íons presentes na água como $\mathrm{Fe}, \mathrm{Mn}$, temperaturas mais elevadas e a possível ação catalítica da enzima catalase presente em células de vegetais e de microorganismos podem ter influenciado o processo de decomposição. Observou-se que dosagens acima de $15 \mathrm{mg} . \mathrm{L}^{-1} \mathrm{em}$ água de rio contendo DB0 $=24,0 \mathrm{mg} \cdot \mathrm{L}^{-1}$ não apresentaram aumento na velocidade de decaimento do oxidante. Em água de rio após precipitação de chuva de $13 \mathrm{~mm}$ contendo $[\mathrm{COT}]=7,0 \mathrm{mg} \cdot \mathrm{L}^{-1}$, foi verificado uma dosagem ótima de 5,0 mg. $\mathrm{L}^{-1}$ $\mathrm{H}_{2} \mathrm{O}_{2}$ devido à satisfatória velocidade de decaimento e de OD fornecido ao rio.

3. Após o tempo reacional de 24 horas não foi verificado alterações significativas do $\mathrm{pH}$ nas amostras com diferentes dosagens de $\mathrm{H}_{2} \mathrm{O}_{2}$, mantendo-se semelhantes ao $\mathrm{pH}$ inicial da água do rio em estudo.

4. Apenas as dosagens iniciais aplicadas de [1,0] a [5,0] mg. $\mathrm{L}^{-1} \quad \mathrm{H}_{2} \mathrm{O}_{2}$ decaíram para $\left[\mathrm{H}_{2} \mathrm{O}_{2}\right]<1 \mathrm{mg} . \mathrm{L}^{-1}$ no tempo desejável de $12 \mathrm{~h}$, de acordo com os limites ecotoxicológicos adotados neste estudo para a manutenção da vida aquática. 
5. A remediação destes corpos hídricos através da aplicação de dosagens de peróxido de hidrogênio mostrou-se eficiente para o processo de suplementação de oxigênio dissolvido por via de decomposição do peróxido. Águas do rio sem adição de peróxido demandaram de maior tempo para depurar os poluentes presentes e reestabelecer suas concentrações de oxigênio, sendo necessário um tempo maior que 24 horas para que houvesse um acréscimo de OD suficientemente sustentável. Ao passo que em poucas horas as águas dos rios dosadas com peróxido alcançaram tais níveis de OD.

6. Caso durante episódios de elevada precipitação o OD presente na LRF apresente valores críticos antes mesmo do evento de deságue dos rios, potencializando déficits críticos de oxigênio, a aplicação do peróxido de hidrogênio nas águas dos rios pode acelerar o processo de depuração das plumas de poluição a jusante da comporta do Canal, podendo assegurar a manutenção de OD > 4,0 mg. $\mathrm{L}^{-1}$ no corpo da pluma e desse modo prevenir o acontecimento de mortandade de peixes. 


\section{Sugestões para Trabalhos Futuros}

1- $\quad$ Em função do que foi estudado e apresentado, é sugerido para um melhor entendimento da influência da ecotoxicidade, a realização de testes ecotoxicológicos para verificação das concentrações do peróxido e do tempo de exposição sobre espécies aquáticas locais da LRF. Segundo a literatura, os organismos testes indicadores de toxicidade utilizados largamente nas mais diversas matrizes são ouriços do mar, peixes, vegetais e microorganismos.

2- $\quad$ É sugerido também testes em diferentes concentrações de peróxido em corpos hídricos com maiores concentrações de poluentes orgânicos, cuja concentração seja maior do que a dos corpos hídricos do presente estudo, a fim de avaliar o fornecimento de oxigênio e o tempo demandado durante o processo de depuração para alcançar níveis mínimos aceitáveis pela legislação.

3- Avaliar em menores tempos reacionais o decaimento das concentrações residuais do oxidante para as menores dosagens de $\mathrm{H}_{2} \mathrm{O}_{2}$ aplicadas às águas com alta carga orgânica.

4- Realizar o modelamento de dispersão da pluma de poluentes não conservativos tanto para a Bacia hidrográfica da Lagoa Rodrigo de Freitas quanto para outros corpos hídricos que recebam altas concentrações de poluentes orgânicos que se avalie estudar.

5- Simular matematicamente e em modelo de escala reduzida o processo de depuração acelerada com peróxido em diversas condições de DBO e volume de água de rio lançado sobre a Lagoa, acompanhando a evolução da pluma originada na comporta da Gal. Garzón, sua dispersão para norte e para sul do canal da Ilha do Piraquê, e o monitoramento na mesma dos parâmetros $\mathrm{OD}$ e $\left[\mathrm{H}_{2} \mathrm{O}_{2}\right]$.

6- Avaliar em maior frequência alguns parâmetros de qualidade da água regidos pelo CONAMA 357/05 em eventos com maiores variações de volume de precipitação do corpo hídrico deste estudo, para comparação e interpretação dos dados. 


\section{Referências Bibliográficas}

ANA, Agência Nacional De Águas. Ministério Do Meio Ambiente - O Comitê De Bacia Hidrográfica: O Que É E O Que Faz? Cadernos de capacitação em recursos Hídricos, Volume 1. Brasília - Df, 2011.

ANA, Agência Nacional De Águas. Guia Nacional de Coleta e Preservação de Amostras de Águas da Agência Nacional de Águas, ANA. 2012.

A.LIU; Egodawatta, Prasanna; Guan, Yuntao; Goonetilleke, Ashantha. Influence of rainfall and catchment characteristics on urban stormwater quality. Science of the Total Environment 444 (2013).

ANDRADE, Henrique Antonio de Salles. Conclusões químicas sobre as razões da ocorrência de mortandade súbita na Lagoa Rodrigo de Freitas com base no balanço de materiais. Pontifícia Universidade Católica do Rio de Janeiro, 1973. Tese de doutorado.

ANDREATA, José V.; Marca, Alex G.; Soares, Cláudio L.; Santos, Rubens da S. Distribuição mensal dos peixes mais representativos da Lagoa Rodrigo de Freitas, Rio de Janeiro, Brasil. Revista bras. Zool. 14 (1): 121- 134, 1997.

ARELANO, Meryelem T. C. Tratamento de efluentes contendo cianeto por oxigênio singlete gerado através da reação de peróxido de hidrogênio e hipoclorito de sódio. Departamento de Engenharia de Materiais e Processos Químicos e Metalúrgicos - DEMa, PUC Rio, 2012. Dissertação de Mestrado.

ARVIN, Erik; PEDERSEN, Lars-Flemming. Hydrogen peroxide decomposition kinetics in aquaculture water. Aquacultural Engineering 64, 1-7. 2015.

ABNT NBR 9898/97. Associação Brasileira de Normas Técnicas -. Preservação e técnicas de amostragem de efluentes líquidos e corpos receptores. 
ABNT NBR 9897/87. Associação Brasileira de Normas Técnicas - Planejamento de amostragem de efluentes líquidos e corpos receptores.

BELOTTI, Fernanda M. Capacidade de Retenção de Metais Pesados pelo Solo em Área de Implantação de Estruturas de Infiltração para Águas Pluviais Urbanas em Belo Horizonte/MG. Universidade Federal de Minas GeraisUFMG. 2011.

BEZERRA, Iury Steiner de Oliveira; MENDONCA, Luiz Alberto Ribeiro; FRISCHKORN, Horst. Autodepuração de cursos d'água: um programa de modelagem Streeter Phelps com calibração automática e correção de anaerobiose. Rem: Rev. Esc. Minas, Ouro Preto, v. 61, n. 2, June 2008.

BOCAIUVA, A. de Lima. Área de Preservação Permanente Ripária Urbana: Estudo de Caso do Rio Rainha. Rio de Janeiro, 2012. Dissertação de Mestrado.

BRAGA, B. Introdução à engenharia ambiental: o desafio do desenvolvimento sustentável. 2 ed. São Paulo: Pearson PrenticeHall, 2005.

BRITO, J. G.; SOUSA, A. K. F.; MERA, P. A. S.; ALVES, L. F. Avaliação da qualidade da água de rios da Amazônia Central. In: REUNIÃO ANUAL DA SOCIEDADE BRASILEIRA PARA O PROGESSO DA CIÊNCIA, 62, 2010, Natal. Rio de Janeiro: SBPC, 2010.

CARROLL, Steven; An Liu; Les Dawes; Hargreaves, M. \& Goonetilleke, A. Role of Land Use and Seasonal Factors in Water Quality Degradations. Springer Science 2013.

CARVALHO, N de O. Hidrossedimentologia prática. CPRM - Companhia de Pesquisa em Recursos Minerais, Rio de Janeiro, RJ. 1994.

CEDAE, Companhia Estadual de Águas e Esgotos. Histórico da qualidade da Lagoa Rodrigo de Freitas, 2014. http://www.cedae.com.br/. 
CETESB, Companhia Ambiental Do Estado De São Paulo. Significado Ambiental e Sanitário das Variáveis de Qualidade das Águas e dos Sedimentos e Metodologias Analíticas e de Amostragem. Qualidade Das Águas Interiores No Estado De São Paulo, Série Relatórios, 2009.

CETESB, Companhia Ambiental do Estado de São Paulo. Toxicidade do $\begin{array}{lll}\text { Peróxido de Hidrogênio. } & \text { de }\end{array}$ http://sistemasinter.cetesb.sp.gov.br/produtos/ficha_completa.

CHANG, W.Y.B. and Hai Ouyang. Dynamics of dissolved oxygen and vertical circulation in fish ponds. Aquaculture, Pearl River Fisheries Institute, Chinese Academy of Fisheries, Guangzhou. China, 1988.

CLAR, Michael L.; Barfield, Billy J.; O’Connor, Thomas P. Stormwater Best Management Practice. Environmental Protection and Development. United States Office of Research EPA/600/R-04/121. Agency Washington DC. September 2004.

COELHO, Vitor M. Barbosa. Baía de Guanabara: uma história de agressão ambiental. Casa da Palavra. Rio de Janeiro, 2007.

DANTAS, Tirzhá Lins Porto. Decomposição de peróxido de hidrogênio em um catalisador híbrido e oxidação avançada de efluente têxtil por reagente fenton modificado. Universidade Federal de Santa Catarina/UFSC, 2005. Dissertação de Mestrado.

Da SILVA, Carla G., e COLLINS, Carol H. Aplicações de cromatografia líquida de alta eficiência para o estudo de poluentes orgânicos emergentes. Química Nova, Vol. 34, No. 4, 665-676, 2011.

DE LAAT, Joseph and GALLARD, Herveä. Catalytic Decomposition of Hydrogen Peroxide by $\mathrm{Fe}(\mathrm{III})$ in Homogeneous Aqueous Solution: Mechanism and Kinetic Modeling. Environ. Sci. Technol. 1999, 33, 2726-2732. France. 
DE PAULA, Thiago Pires. Análise hidrodinâmica e de renovação de massas d'água na Lagoa Rodrigo de Freitas através do uso de modelagem computacional. Universidade Federal do Rio de Janeiro- UFRJ/COPPE, 2009.

DEZOTTI, Marcia. Processos e técnicas para o controle ambiental de efluentes líquidos. II serie. -Rio de Janeiro: Escola Piloto em Engenharia Química, COPPE/UFRJ; 2008.

DOMINGOS, Patrícia; Gômara, Gisele A.; Sampaio, Glaucia F.; Soares, Mauricio F. e Soares, Lopes, Fátima de F. Eventos de mortandade de peixes associados a florações fitoplanctônicas na lagoa Rodrigo de Freitas: programa de 10 anos de monitoramento. Oecologia Australis 16(3): 441-466, Setembro 2012.

EL-SOUSY, Khaled; Hussen, Ahmed; Hartani, Khaled and El-Aila, Hisham. Elimination of organic pollutants using supported catalysts with hydrogen peroxide. Jordan Journal of Chemistry Vol. 2 No.1, 2007, pp. 97-103.

ENVIRONMENT AGENCY. Development of operational and policy guidance on the use of hydrogen peroxide. 1998.

ENZWEILER, J. Amostragem de águas e parâmetros de qualidade. UNICAMP, 2010.

EPA, United States Environmental Protection Agency. Ecological risk and fate assessment for proxitane, microbiocide label to add disinfection of sewage and wastewater effluent. D.C. 000595. July, 2007.

EPA, United States Environmental Protection Agency. Water: Monitoring \& Assesment- Dissolved Oxigen. 2012. Acessado em 01/11/2014. http://water.epa.gov/.

EPA, United States Environmental Protection Agency. Office of Prevention, Pesticides and Toxic Substances. Washington, D.C. 20460. July, 2007. 
ERICKSON, A.J.; Weiss, P,T; Gulliver, J.S. Impacts and composition of Urban Stomwater. A handbook of Assesment and a Maintenance. 2013, XII, 337 p.108.

ESTEVES, F. A. \& FURTAdo, A. L. S. Oxigênio dissolvido. ESTEVES, F. A. (ed.). Fundamentos de Limnologia. 3ạ Ed. Editora Interciência, Rio de Janeiro, RJ. 790p. 2011.

FROEHNER, S.; MARTINS, Raquel F. Avaliação da composição química de sedimentos do Rio Barigüi na região metropolitana de Curitiba. Quím. Nova, São Paulo, v. 31, n. 8, 2008.

GRASSI, Marco Tadeu. UNICAMP, Cadernos Temáticos de Química Nova. Edição Especial. Maio, 2001. São Paulo, SP.

GEORGE, P. Reaction Between Catalase and Hydrogen Peroxide. Nature 160, 41-43 (12 July 1947).

HENZE, Mogens; van Loosdrecht. Mark C. M.; EKAMA, George A. Biological Wastewater Treatment: Principles, Modeling and Design. IWA Publishing. 36p. 2008.

HESPANHOL, K. M. Hipolito. Monitoramento e diagnóstico da água do Ribeirão Mangueiro. Universidade Estadual de Maringá. 2009. Dissertação de mestrado.

HOSETTI, B. B.; FROST, S. Catalase activity in wastewater. Water Research. Vol. 28, No. 2, pp. 497-500, 1994.

JOSEPH, Alina J.; MADGULA, K. e KAKKAR, RITA. Clean EnvironmentClean Technologies, Hydrogen Peroxide for Clean Environment. Current World Environment Vol. 6(1), 125-130 (2011). 
KANNEL, Prakash R.; Lee, Seockheon; Lee, Young-Soo; Raj Kanel, S.; Khan, Siddhi P. Application of Water Quality Indices and Dissolved Oxygen as Indicators for River Water Classification and Urban Impact Assessment . Springer Science, 2007.

KAVANAUGH, M.; Chowdhury, Z. Removal of Mtbe with advanced oxidation process. London, UK. 2003.

KNAPIK, Heloise G. \& Scapulatempo, Cristovão V. Fernandes \& Azevedo, Julio Cesar R. de Caracterização e monitoramento de matéria orgânica em rios: aplicabilidade na gestão de recursos hídricos. Associação Brasileira de Recursos Hídricos- Simpósio Brasileiro de Recursos Hídricos. 2013.

KSIBI, Mohamed. Chemical oxidation with hydrogen peroxide for domestic wastewater treatment. Chemical Engineering Journal 119 161-165. 2006.

LEE, JUN HO M.; and BANG, KI W. Characterization of urban stormwater runoff. South Korea. Vol. 34, No. 6, pp. 1773-1780. Elsevier Science, 2000.

LEHNER, Peter; Clark, George P. Aponte; Cameron, Diane M.; Frank, Andrew G.. Stormwater Strategies: Community Responses to Runoff Pollution. Chapter 2- The Causes Of Urban Stormwater Pollution. 1999. http://www.nrdc.org/water/pollution/storm/chap2.asp

LIBÂNIO, Marcelo; Libânio Cunha, Paulo A.; Costa, Bruno M. Pyramo. Avaliação da relevância do carbono orgânico total como parâmetro de caracterização de águas de abastecimento. Departamento de Engenharia Hidráulica e Recursos Hídricos da UFMG. RBRH - Revista Brasileira de Recursos Hídricos Volume 5 n.4 Out/Dez 2000.

LIPPINCOTT Williams e WILKINS. Disinfection, Sterilization, and Preservation. Editor Seymor S. Bolock, fifth edition. Philadelphia, USA. 2001. 
LONGHINI, C. M. Biogeoquímica do carbono no platô recifal de coroa vermelha, Santa Cruz de Cabrália - Bahia. UESC, 2010.

LOUREIRO, Daniel Dias. Comportamento do mercúrio em lagoas costeiras urbanas: das mudanças paleoambientais ao balanço de massa (Estudo de caso: Lagoa Rodrigo de Freitas). UFF, 2010. Tese de doutorado.

LOUREIRO, Daniel Dias. Evolução dos aportes de metais pesados na Lagoa Rodrigo de Freitas, RJ. Universidade Federal Fluminense. Dissertação. 2006.

LUCAS, Luciano M. \& CUNHA, Sandra B. Rede de drenagem urbana em área tropical: mudanças na morfologia do canal e níveis de poluição das águas Rio dos Macacos - Rio de Janeiro - RJ. GEO USP - Espaço e Tempo, São Paulo, No 22, pp. 39 - 64, 2007.

\section{MACHADO, Ligia Bernardo. Evolução da degradação ambiental da bacia} hidrográfica da Lagoa Rodrigo de Freitas - RJ. UERJ, 2009. Dissertação de mestrado.

MALAIANDY, M. Muruoan; SADAR, Husain; LEE, Pauline and O'GRADY, Ron. Removal of organics in water using hydrogen peroxide in presence of ultraviolet light. Water Research. Vol. 14, pp. 1131 to 1135.1980.

MARCElinO, R. B. P.; Frade, P. R.; Amorim, C. C.; Leão, M. M. D. Tendências e desafios na aplicação de tecnologias avançadas para o tratamento de efluentes industriais não biodegradáveis: atuação do grupo de pesquisas POA Control da UFMG. Rev. UFMG, Belo Horizonte, v. 20, n.2, p. 358-383. 2013.

MANUAL DE ANÁLISES FÍSICO-QUÍMICAS DE ÁGUAS DE ABASTECIMENTO E RESIDUÁRIAS, UFRJ. Laboratório de Núcleo Integrado para Reuso de Águas e Efluentes do Estado do Rio de Janeiro (NIRAERJ).

MATTOS, Ivanildo L. de; Shiraishi, Karina A.; Braz, Alexandre Delphini e Fernandes, João R. Peróxido de hidrogênio: importância e determinação. 
Departamento de Química, Faculdade de Ciências, Universidade Estadual Paulista (UNESP), SP. Quim. Nova, Vol. 26, No. 3, 373-380, 2003.

MELO, Marília Carvalho de. Avaliação e proposição de critérios de outorga para lançamento de efluentes em corpos d'água. Universidade Federal de Minas Gerais. Dissertação de Mestrado

MIGUEZ, Marcelo G.; REZENDE, Osvaldo M. \& VERÓL, Aline P. Interações entre o Rio dos Macacos e a Lagoa Rodrigo de Freitas sob a ótica dos problemas de drenagem urbana e ações integradas de revitalização ambiental. Oecologia Australis, Setembro 2012.

Ministério do Meio Ambiente, 2013.

http://www.mma.gov.br/estruturas/sedr_proecotur/_publicacao/140_publicacao09 062009025910.pdf.

NOGUEIRA, André Almeida. Biofiltração e oxidação avançada para tratamento terciário e reúso de efluente de refinaria de petróleo. Rio de Janeiro: UFRJ/COPPE, 2013. Dissertação de mestrado.

PARRON, Lucilia M.; Muniz, Daphne H. de F.; Pereira, Claudia M.

Manual de procedimentos de amostragem e análise físico-química de água. Empresa Brasileira de Pesquisa Agropecuária- Embrapa Florestas. Ministério da Agricultura, Pecuária e Abastecimento. 2011.

PORTO, Monica F. A.; PORTO, Rubem La Laina. Gestão de bacias hidrográficas. Estud. av., São Paulo, v. 22, n. 63, 2008.

PREFEITURA DA CIDADE DO RIO DE JANEIRO, 2014. http://www.rio.rj.gov.br/ acesso em 10/12/2014.

PROTECTION ENVIRONMENTAL. Hydrogen peroxide, peracetic acid and sodium percarbonate. Massachusetts Department of Environmental Protection. Department of Agricultural Resources. October 2010. 
REINA, A. Cabrera; L. Jordá, Santos-Juanes; Sánchez, J.L. García; López, J.L. Casas; Pérez, J.A. Sánchez. Modelling photo-Fenton process for organic matter mineralization, hydrogen peroxide consumption and dissolved oxygen evolution. Applied Catalysis B: Environmental 119-120 (2012) 132-138.

RESOLUÇÃO CONAMA, CONSELHO NACIONAL DE MEIO AMBIENTE. $\mathbf{N}^{\mathbf{0}}$ 357, DE 17 DE MARÇO DE 2005. Publicada no DOU nº 053, de 18/03/2005, págs. 58-63.

RIO ÁGUAS - Prefeitura da cidade do Rio de Janeiro. Atualização do plano de gestão ambiental da Lagoa Rodrigo de Freitas. Setembro, 2013. http://www.rio.rj.gov.br/.

RIO ÁGUAS - Prefeitura da cidade do Rio de Janeiro. Plano de contingência e monitoramento da Lagoa Rodrigo de Freitas- Julho, 2010.

ROSSO, Thereza Christina de Almeida; D’Alcântara, Werner Bess. Análise hidráulica do sistema de esgotamento sanitário da Lagoa Rodrigo de Freitas, Rio de Janeiro. RBRH- Revista Brasileira de Recursos Hídricos, Volume 11 n.3, 2006.

SANT'ANNA JUNIOR, Geraldo Lippel. Tratamento biologico de efluentes e aplicações. Geraldo Lippel Sant'Anna Junior. - $2^{\mathrm{a}}$ Ed.- Rio de Janeiro: Interciência, 2013.

SCHMIDT, Larry J.; Gaikowski, Mark P. and Gingerich, William H. Fungal and Bacterial Diseases of Cultured Fish and Fish Eggs - Environmental assessment of hydrogen peroxide for aquaculture use. U.S. Geological Survey, Biological Resources Division. Upper Midwest Environmental Sciences Center. 2006. 
SILVA, M. R. A. da; Oliveira, M. C. de; Nogueira, R. F. P. Estudo da aplicação do processo foto-Fenton solar na degradação de efluentes de indústria de tintas. Eclet. Quím., São Paulo , v. 29, n. 2, 2004.

SILVA, S. Cardoso; Nishimura, P. Yuri; Padial, P. Regina; Mariani, C. Fiorillo; Moschini- Ca, Viviane. Compartimentalização e qualidade da água: o caso da represa Billings. Ecologia e Meio Ambiente. Campinas, 2014.

SOUZA, M. F. L.;* Longhini, C. M.; Silva, A. M.; Lentini, C. A. D. Ciclo do Carbono: Processos Biogeoquímicos, Físicos e Interações entre Compartimentos na Baía de Todos os Santos. Rev. Virtual Quim. 2012, 4 (5), $566-582$.

SUBTIL, Eduardo Lucas; Mierzwa, José Carolos; Hespanhol, Ivanildo. Avaliação do desempenho do sistema UV/H2O2 no tratamento de efluentes provenientes do processo de tratamento térmico de emulsões água e óleo. Centro Internacional de Referência em Reuso de Água- USP, 2009.

STREETER, H. W., PHELPS, E. B. A study of the natural purification of the Ohio River. Public Health Bulletin 146, U.S. Washington: Public Health Service, 1925.

TECHNO-BIO. EIA/RIMA. Reabilitação Ambiental da Lagoa Rodrigo de Freitas por Dutos Afogados. 2012.

TEIXEIRA, Claudia P. de A. Barêa e JARDIM, Wilson de Figueiredo. Processos oxidativos avançados- conceitos teóricos. Universidade de Campinas/UNICAMP, Instituto de Química. Campinas, 2004.

TUCCI, Carlos E. M.. Águas urbanas. Estud. av., São Paulo , v. 22, n. 63, 2008. 
TUNAY, Olcay; Kabdasli, Isik; Alaton, Idil Arslan; Hanci, Olmez. Chemical Oxidation- Applications for Industrial Wastewaters. IWA Publishing. Aliance House. London, UK. 2010.

TUNDISI, José Galizia. O Futuro dos Recursos Hídricos. Instituto Internacional de Ecologia. São Carlos-SP. MultiCiência, n.1, 2003.

TUNDISI, José Galizia. Recursos hídricos no futuro: problemas e soluções. Estud. av., São Paulo , v. 22, n. 63, 2008.

VARGAS, Marcelo. O gerenciamento integrado dos recursos hídricos como problema socioambiental. Ambiente \& Sociedade - Ano II - No 5 - $2^{\circ}$ Semestre de 1999.

VUILLEMIN, M.-H. Tusseau; Lagarde, F.; Chauviere, C.; Héduit, A. Hydrogen peroxide (H2O2) as a source of dissolved oxygen in COD-degradation respirometric experiments. Water Research 36 793-798, 2002.

VIOLA, Zenild das Graças Guimarães. Avaliação da qualidade das águas da Bacia do Rio Doce/MG: Caracterização da matéria orgânica e seus impactos ambientais. Universidade Federal de Minas Gerais - UFMG. Belo Horizonte, 2008. Tese de Doutorado.

VON SPERLING, Marcos. "Estudos e Modelagem da Qualidade da Água”. Minas Gerais: DESA/Universidade Federal de Minas Gerais, 2007.

VON SPERLING, Marcos. Introdução à qualidade das águas e ao tratamento de esgotos. $3^{\mathrm{a}}$ ed. - Belo Horizonte: Departamento de Engenharia Sanitária e Ambiental; Universidade Federal de Minas Gerais, 2005.

VON SPERLING, Marcos. Princípios de tratamento biológico de águas residuárias: Introdução e qualidade das águas e do tratamento de esgotos. $2^{\mathrm{a}}$. ed. Belo Horizonte: UFMG, 1996. 
WEERELT, Margaretha D. M. van; Signori, Camila \& Enrich-Prast, Alex. Balneabilidade da Lagoa Rodrigo de Freitas: variação temporal e espacial. Oecologia Australis, Setembro, 2012.

WOLMAN, M. G. A Cycle of Sedimentation and Erosion in Urban River Channels. Geografiska Annaler, vol.49, 1967, p.385-395.

ZHANG, H. and S. Li. Journal of Marine Systems. School of Environmental Science and Engineering, Sun Yat-Sen University, Guangzhou, China. Elsevier, 2009.

ZGHEIB, Sally; Moilleron, Re'gis; Chebbo, Ghassan. Priority pollutants in urban stormwater: Part 1 e Case of separate storm sewers. Universite' ParisEst, LEESU, AgroParisTech, France. Elsevier, 2012.

ZAGATTO, Pedro Antonio. Evoluation ecotoxicologique Du reservoir Guarapiranga, SP- Bresil, em relation avec Le probleme des algues toxiques et ES algicides. Universite de Metz- France. Tese de doutorado. 1995. 


\section{Apêndice}

\section{Apêndice 1}

Apresentação dos resultados para a caracterização das águas no Ponto 1 do canal da Rua Gal. Garzón em tempo seco e chuvoso através de DBO; COT e SST. As coletas ocorreram nos meses de Agosto a Dezembro relativo ao ano de 2014 e mês de Janeiro relativo ao ano de 2015.

Tabela A1-1. Valores de carbono orgânico total (COT), sólidos suspensos totais (SST) e demanda bioquímica de oxigênio (DBO) no ponto 1 do Canal da Rua Gal. Garzón em período seco e chuvoso nos meses de Agosto - 2014 a Janeiro - 2015.

\begin{tabular}{|c|c|c|c|c|c|}
\hline $\begin{array}{c}\text { Local de } \\
\text { Coleta }\end{array}$ & Coleta & $\begin{array}{l}\text { Precipitação de } \\
\text { Chuva } \\
\text { (mm) }\end{array}$ & $\begin{array}{c}\text { Carbono } \\
\text { Orgânico } \\
\text { Total } \\
\text { (COT) }\end{array}$ & $\begin{array}{c}\text { Sólidos } \\
\text { Suspensos } \\
\text { Totais } \\
\text { (SST) }\end{array}$ & $\begin{array}{c}\text { Demanda } \\
\text { Bioquímica } \\
\text { de Oxigênio } \\
\text { (DBO) }\end{array}$ \\
\hline \multirow{9}{*}{$\underset{2}{2}$} & $C 1$ & 0,8 & - & - & 0,9 \\
\hline & $C 2$ & $<0,5$ & 1,97 & - & 1,5 \\
\hline & $C 3$ & $<0,5$ & - & - & 3,4 \\
\hline & $C 4$ & 2,4 & 3,96 & 4 & 2,56 \\
\hline & $C 5$ & 0 & 3,3 & 2 & 3,15 \\
\hline & C6 & 0 & - & - & - \\
\hline & $C 7$ & 13,2 & 5,1 & 2 & - \\
\hline & \multicolumn{2}{|c|}{ DP } & 1,3071 & 1,1547 & 1,0724 \\
\hline & \multicolumn{2}{|c|}{$\mathrm{CV}(\%)$} & 36,5 & 43,4 & 46,58 \\
\hline
\end{tabular}

Apresentação dos resultados do teste estatístico não paramétrico de Kruskal Wallis

Verificou- se a ocorrência de diferença significativa a nível de $\mathrm{p}<0,05$ para as variáveis COT, SST e DBO a fim de observar se havia diferenças entre 
tais variáveis durante os eventos de precipitação e de tempo seco deste estudo no ponto de amostragem 3.

\begin{tabular}{cc}
\hline Variável & $\mathrm{p}$ - value \\
\hline COT & 0,5127 \\
SST & 0,1386 \\
DBO & 0,5127 \\
\hline
\end{tabular}

\section{Apêndice 2}

\section{Avaliação da velocidade inicial de decaimento do peróxido de hidrogênio}

A velocidade inicial de decaimento das concentrações de $\mathrm{H}_{2} \mathrm{O}_{2}$ foi calculada a partir das concentrações de peróxido, nos respectivos tempos.

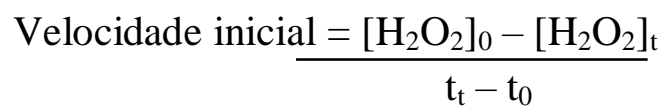

Onde:

$\mathrm{t}_{0}=0$

$\mathrm{t}_{\mathrm{t}}=$ tempo escolhido

$\left[\mathrm{H}_{2} \mathrm{O}_{2}\right]_{0}=$ concentração inicial de peróxido de hidrogênio

$\left[\mathrm{H}_{2} \mathrm{O}_{2}\right]_{\mathrm{t}}=$ concentração de peróxido de hidrogênio no tempo t.

\section{Cálculo da percentagem de remoção de COT}

Considerando a concentração de COT presente no rio antes do tratamento com $\mathrm{H}_{2} \mathrm{O}_{2}$ (concentração inicial) e a concentração de COT após 24 horas do tratamento (concentração final) $\operatorname{com~} \mathrm{H}_{2} \mathrm{O}_{2}$.

$$
\% \text { de remoção de COT }=\frac{[\mathrm{COT}]_{0}-[\mathrm{COT}]_{\mathrm{t}}}{[\mathrm{COT}]_{0}} \times 100
$$




\section{Apêndice 3}

Apresentação dos resultados de decaimento das dosagens de peróxido de hidrogênio versus tempo para os testes a partir das coletas dos meses de Agosto a Novembro relativo ao ano de 2014 e mês de Janeiro relativo ao ano de 2015.

Tabela A3-1 Constantes de pseudo-primeira ordem de decaimento do peróxido de hidrogênio em concentrações de $[1,5],[5,0],[11,0]$ e $[20,0] \mathrm{mg} . \mathrm{L}^{-1}$ ao término de 1 dia de reação do experimento 2. Características da amostra: DBO5: 1,4 mg. $\mathrm{L}^{-1}$; COT: $0,98 \mathrm{mg} . \mathrm{L}^{-1}$; SST: 4,0 mg. $\mathrm{L}^{-1}$. A pluviosidade acumulada do dia ficou abaixo de $0,5 \mathrm{~mm}$.

\begin{tabular}{ccc}
\hline \multicolumn{3}{c}{ Experimento 2 - Mês de Setembro/2014 } \\
\hline$\left[\mathrm{H}_{2} \mathrm{O}_{2}\right]_{0}\left(\mathrm{mg} . \mathrm{L}^{-1}\right)$ & $\mathbf{K}_{\text {obs }}\left(\mathbf{m i n}^{-1}\right)$ & $\mathbf{R}^{\mathbf{2}}$ \\
& & \\
$\mathbf{1 , 5}$ & 0,0009 & 0,9257 \\
$\mathbf{5 , 0}$ & 0,0012 & 0,9847 \\
$\mathbf{1 1 , 0}$ & 0,0016 & 0,9365 \\
$\mathbf{2 0 , 0}$ & 0,0003 & 0,9889 \\
\hline
\end{tabular}

Tabela A3-2 Constantes de pseudo-primeira ordem de decaimento do peróxido de hidrogênio em concentrações de [1,5], [5,0], [11,0] e [20,0] mg. $L^{-1}$ ao término de 1 dia de reação do experimento 3. Os valores das constantes de concentrações $[1,0]$ e $[5,0] \mathrm{mg} / \mathrm{L}$ foram calculadas após $2^{\mathrm{a}}$ dosagem de peróxido. Características da amostra: DBO5: 24,1 mg. $\mathrm{L}^{-1}$; COT: - mg.L $\mathrm{L}^{-1}$; ST: 15,3 mg.L $\mathrm{L}^{-1}$. A pluviosidade acumulada do dia ficou abaixo de 0,5 mm. No momento da coleta ocorria contribuição do Canal do Jockey. 


\begin{tabular}{ccc}
\hline \multicolumn{3}{c}{ Experimento 3 - Mês de Novembro/2014 } \\
\hline$\left[\mathrm{H}_{2} \mathrm{O}_{2}\right]_{0}\left(\mathrm{mg}_{\mathrm{L}} \mathrm{L}^{-1}\right)$ & $\mathbf{K}_{\text {obs }}\left(\mathbf{m i n}^{-1}\right)$ & $\mathbf{R}^{\mathbf{1}}$ \\
& - & - \\
$\mathbf{1 , 0}$ & & - \\
& - & - \\
$\mathbf{5 , 0}$ & 0,0014 & 0,913 \\
$\mathbf{1 5 , 0}$ & 0,0005 & 0,7644 \\
\hline $\mathbf{2 0 , 0}$ & & \\
\hline
\end{tabular}

Tabela A3-3 Constantes de pseudo-primeira ordem de decaimento do peróxido de hidrogênio em concentrações de [1,5], [3,0] e $[5,0] \mathrm{mg} . \mathrm{L}^{-1}$ ao término de 1 dia de reação do experimento 4. Características da amostra: COT: 7,0 mg.L $\mathrm{L}^{-1}$; SST: $24,0 \mathrm{mg} . \mathrm{L}^{-1}$. A pluviosidade acumulada do dia foi de $13,2 \mathrm{~mm}$.

\begin{tabular}{ccc}
\hline \multicolumn{3}{c}{ Experimento 4 - Mês de Janeiro/2015 } \\
\hline$\left[\mathrm{H}_{2} \mathrm{O}_{2}\right]_{0}\left({\left.\mathrm{mg} . \mathrm{L}^{-1}\right)}\right.$ & $\mathbf{K}_{\text {obs }}\left(\mathbf{m i n}^{-1}\right)$ & $\mathbf{R}^{\mathbf{2}}$ \\
$\mathbf{1 , 5}$ & 0,0038 & 0,9786 \\
& & \\
$\mathbf{3 , 0}$ & 0,0043 & 0,9351 \\
$\mathbf{5 , 0}$ & 0,0038 & 0,9717 \\
\hline
\end{tabular}

\section{Apêndice 4}

Apresentação dos valores de pH medidos após 24 horas de contato da água do rio com o peróxido de hidrogênio.

Tabela A4-1 Valores de pH obtidos após término de reação (24 horas) do peróxido em concentrações de [1,5], [5,0], [11,0] e [20,0] mg.L $\mathrm{L}^{-1}$ em amostras do Ponto 3 do Canal Gal. Garzón. Características da amostra: DBO5: 1,4 mg.L $\mathrm{L}^{-1}$; COT: 0,98 mg.L ${ }^{-1}$; SST: 4,0 mg.L $\mathrm{L}^{-1}$. A pluviosidade acumulada do dia ficou abaixo de $0,5 \mathrm{~mm}$. 
Experimento 2 - Mês de Setembro/2014

\begin{tabular}{cc}
\hline$\left[\mathrm{H}_{2} \mathrm{O}_{2}\right]$ & $\mathrm{pH}($ final $)$ \\
$(\mathrm{mg} / \mathrm{L})$ & \\
\hline $\mathbf{1 , 5}$ & 7,4 \\
$\mathbf{5 , 0}$ & 7,5 \\
$\mathbf{1 1 , 0}$ & 7,5 \\
$\mathbf{2 0 , 0}$ & 7,5 \\
\hline
\end{tabular}

Obs.: $\mathrm{O}$ valor inicial do $\mathrm{pH}$ do rio: 7,3.

Tabela A4-2 Valores de $\mathrm{pH}$ obtidos após término de reação (24 horas) do peróxido em concentrações de [1,5], [3,0] e [5,0] mg.. $\mathrm{L}^{-1}$ em amostras Ponto 3 do Canal Gal. Garzón. Características da amostra: DBO5: -- mg.. $\mathrm{L}^{-1}$; COT: 7,0 mg. $\mathrm{L}^{-1}$; SST: 24,0 mg. $\mathrm{L}^{-1}$. A pluviosidade acumulada do dia foi de 13,2 $\mathrm{mm}$.

Experimento 4 - Mês de Janeiro/2015

\begin{tabular}{cc}
\hline$\left[\mathrm{H}_{2} \mathrm{O}_{2}\right]$ & $\mathrm{pH}$ (final) \\
$(\mathrm{mg} / \mathrm{L})$ & \\
\hline $\mathbf{1 , 5}$ & 7,05 \\
$\mathbf{3 , 0}$ & 7,04 \\
$\mathbf{5 , 0}$ & 7,05 \\
\hline
\end{tabular}

Obs.: O valor inicial do $\mathrm{pH}$ do rio: 7,03. 